Universidade de São Paulo

Faculdade de Filosofia, Letras e Ciências Humanas

Departamento DE LinguísticA

Programa de Pós-GraduaÇão em Semiótica e Linguística Geral

\author{
LuCAS TAKeO Shimoda
}

\title{
Por um estudo semiótico do timbre na fala, na canção e na música
}

(Versão corrigida CONFORMe a ResoluÇÃo CoPGr 6018)

São Paulo

2020 


\section{Por um estudo semiótico do timbre na fala, na canção e na música}

(VERSÃo CORRIGIDA CONFORME A RESOLUÇÃo CoPGr 6018)

Tese apresentada ao Programa de PósGraduaÇão em Semiótica e Linguística GeRAL Do Departamento DE Linguística DA Faculdade de Filosofia, Letras e CiênCias Humanas da Universidade de São Paulo PARA A OBTENÇÃo DO TÍtUlo DE Doutor EM LiNGUíSTICA.

Orientador: Prof. Dr. Luiz Augusto de Moraes Tatit 
Autorizo a reprodução e divulgação total ou parcial deste trabalho, por qualquer meio convencional ou eletrônico, para fins de estudo e pesquisa, desde que citada a fonte.

Catalogação na Publicação

Serviço de Biblioteca e Documentação

Faculdade de Filosofia, Letras e Ciências Humanas da Universidade de São Paulo

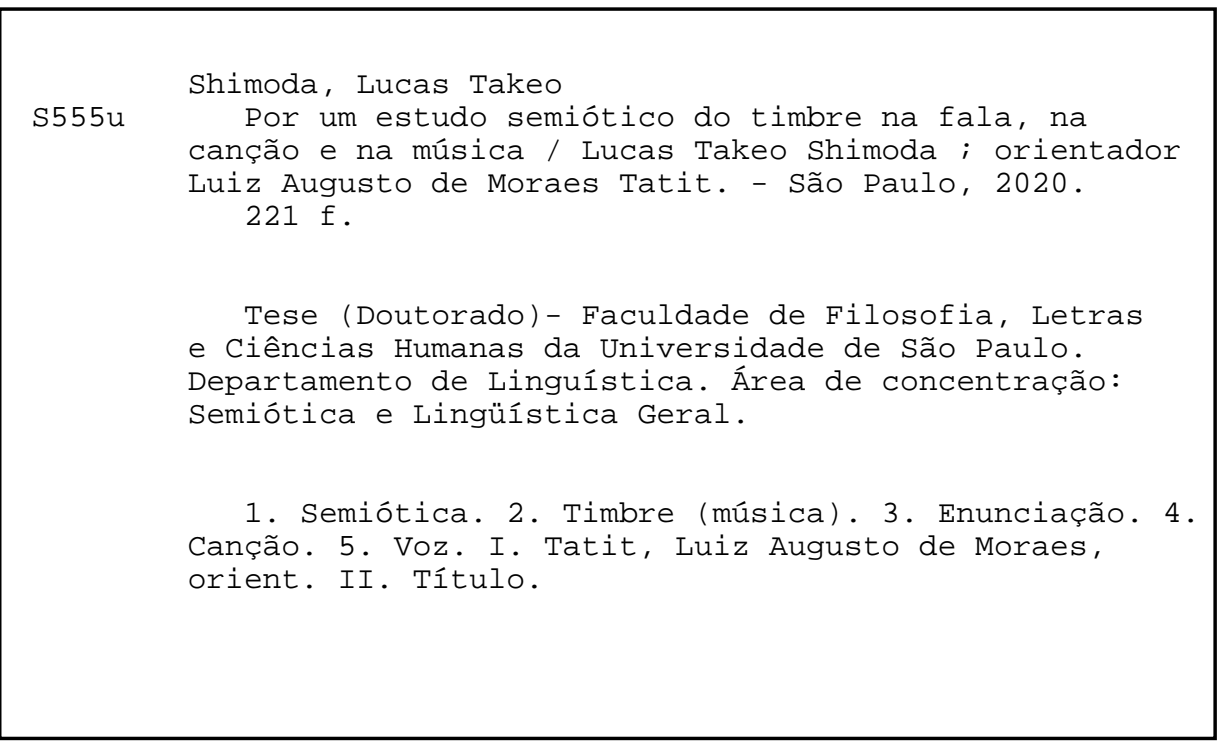


SHIMODA, Lucas Takeo. Por um estudo semiótico do timbre na fala, na canção e na música. Tese apresentada à Faculdade de Filosofia, Letras e Ciências Humanas da Universidade de São Paulo para obtenção do título de doutor em Semiótica e Linguística Geral.

Aprovação em: 16/03/2020.

\section{Banca examinadora}

Prof.(a) Dr.(a): Luiz Augusto de Moraes Tatit

Instituição: Universidade de São Paulo

Presidente da Banca

Prof.(a) Dr.(a): Ivã Carlos Lopes

Instituição: Universidade de São Paulo

Julgamento: Aprovação

Prof.(a) Dr.(a): Carolina Lindenberg Lemos

Instituição: Universidade Federal do Ceará

Julgamento: Aprovação

Prof.(a) Dr.(a): Márcio Gusmão Coelho

Instituição: Externo

Julgamento: Aprovação 


\section{Termo de Ciência e Concordância do Orientador}

Nome do aluno: Lucas Takeo Shimoda

Data da defesa: 15/05/2020

Nome do Prof. Orientador: Prof. Dr. Luiz Augusto de Moraes Tatit

Nos termos da legislação vigente, declaro estar ciente do conteúdo deste exemplar corrigido elaborado em atenção às sugestões dos membros da comissão Julgadora na sessão de defesa do trabalho, manifestando-me plenamente favorável ao seu encaminhamento e publicação no Portal Digital de Teses da USP.

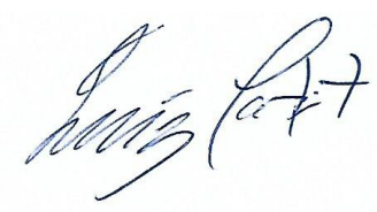

São Paulo, 15/05/2020 


\section{Dedicatória}

Aos que resistem. 


\section{Agradecimento}

Aos que me orientaram, dentro e fora das instâncias oficiais.

Aos que me lecionaram.

Aos que me impuseram limites.

Aos que me ensinaram a querer voar alto e ter raízes profundas.

Aos que me inquietaram quando o conforto parecia a saída mais fácil.

Aos que me acompanharam.

Aos que me amaram.

Aos que me toleraram.

Aos que tiveram coragem.

Aos que levantaram a sua voz quando a omissão era mais conveniente.

Aos que comigo dividiram angústias, sonhos, textos, abraços, teto e café.

Aos que compartilharam o que sabiam sem nada esperar em troca.

Aos que levaram linguística para mais perto da educação básica.

Ao Conselho Nacional de Desenvolvimento Científico e Tecnológico (CNPq), pelo auxílio financeiro que possibilitou a realização deste trabalho. É o financiamento público que garante produção científica independente e de qualidade. 
"Aquela voz certamente vem de uma pessoa única, inimitável como

qualquer pessoa, porém uma voz não é uma pessoa, é algo de suspenso no ar, destacado da solidez das coisas. Também a voz é única e inimitável, mas talvez num outro modo diferente da pessoa: poderiam voz e pessoa não se parecer. Ou então assemelhar-se de um modo secreto, que não se vê à primeira vista: a voz poderia ser o equivalente daquilo que a pessoa tem de mais oculto e de mais verdadeiro." 


\section{Resumo}

SHIMODA, Lucas Takeo. Por um estudo semiótico do timbre na fala, na canção e na música. 2020. 222 f. Tese (Doutorado) - Faculdade de Filosofia, Letras e Ciências Humanas, Universidade de São Paulo, 2020.

O presente trabalho tem por objetivo primário compreender os mecanismos de significação e as estratégias discursivas subjacentes à seleção e à combinação de timbres em discursos verbais, musicais e cancionais. Para dar conta da diversidade de manifestações do timbre, foi empregado o aparato teórico da semiótica discursiva conforme desenvolvido por Greimas (1976 [1966], 1975b, 1983b); Greimas \& Courtés (1986, 2012 [1979]), expandido por Zilberberg (1991, 2004, 2006a, 2011a,b); Fontanille \& Zilberberg (2001), bem como seus desenvolvimentos aplicados à canção popular por Tatit (1986, 1997, 2004b, 2014, 2016). Uma revisão crítica da literatura da área revelou que a seleção de timbres em textos cancionais está estreitamente relacionada à sua função de remissão à fonte sonora, notadamente o intérprete no caso da canção popular e o instrumento no caso do arranjo e da música instrumental. Para descrever esse fenômeno, o conceito semiótico de figuratividade e de densidade sêmica foi empregado na elaboração de uma escala contínua de especificidade partindo do mais genérico ao mais específico. Essa escala gradual pode ser segmentada em três grandes regiões, a saber, um grau mínimo, um grau intermediário e um grau máximo de especificação. No nível mínimo de densidade figurativa, o timbre é inespecífico e só permite o reconhecimento de qualidades abstratas, manifestas na forma de adjetivos sinestésicos que traduzem verbalmente a morfologia temporal do envelope sonoro. No grau intermediário, encontram-se as descrições e categorizações de timbres em famílias. As fronteiras entre essas famílias podem ser melhor delineadas verificando sua (in)compatibilidade intertimbrística mútua, semioticamente traduzíveis em termos de triagens e misturas (Zilberberg, 2004), conforme manifestadas pelas técnicas de orquestração e arranjo. No último grau de densidade semântica, encontram-se os timbres atribuídos a entidades únicas e exclusivas no mundo natural. Frequentemente, esses timbres são designados por antropônimos. O exame de objetos empíricos revelou que timbres com alta densidade figurativa assumem a propriedade de ativar operações enunciativas concorrentes e paralelas àquelas desencadeadas pelo aparelho formal da enunciação (Benveniste, 2006 [1974]). Nesse cenário, o timbre impõe coerções combinatórias fortes a seu respectivo substrato linguístico-musical, dado que a troca de revestimento timbrístico pode neutralizar ou contradizer o efeito de autenticidade gerado pela ilusão enunciativa (Tatit, 2016). Os resultados das análises evidenciam que, apesar do amplo espectro de variabilidade, as possibilidades de seleção e combinação de timbres não são irrestritas. Os dados permitem concluir que timbres genéricos (i.e. figurativamente rarefeitos) se comportam como variantes e podem ser livremente substituídos, ao passo que timbres específicos tendem a se comportar como invariantes e efetuar comutação, na acepção glossemática destes termos (Hjelmslev, 2006 [1943]). Esses achados relativizam a premissa, detectada no levantamento bibliográfico, de que o timbre é uma variável livremente substituível em textos verbais orais, musicais e cancionais.

Palavras-Chave: Semiótica, Timbre, Enunciação, Canção, Voz. 


\section{Abstract}

SHIMODA, Lucas Takeo. Towards a semiotic study of timbre in speech, song and music. 2020. 222 f. Tese (Doutorado) - Faculdade de Filosofia, Letras e Ciências Humanas, Universidade de São Paulo, 2020.

This work aims to describe the meaning mechanisms and discursive strategies underlying the selection and combination of timbres in speech, music and song. In order to take account of this variety of manifestations of timbre, the theoretical framework of semiotics was employed as developed by Greimas (1976 [1966], 1975b, 1983b); Greimas \& Courtés (1986, 2012 [1979]), expanded by Zilberberg (1991, 2004, 2006a, 2011a,b); Fontanille \& Zilberberg (2001), as well as its applications to the Brazilian popular song as proposed by Tatit $(1986,1997,2004 b, 2014,2016)$. A critical literature review has disclosed that timbre selection in songs is closely related to its function of indexing the sound source, namely the singer in the popular song and the musical instrument in arrangements and instrumental music. In order to describe this phenomenon, the semiotic concepts of figurativity and semic density were applied in the construction of a scale of specificity spanning the whole timbre continuum from the most generic to the unique ones. This gradual scale can be divided into three great zones corresponding to a minimum, an intermediate and a maximal degree of specification. At the minimal level of density, timbre is unspecific and only allows the recognition of abstract qualities, manifested as synesthetic adjectives which translate verbally the temporal morphology of sound envelope. At the intermediate level, there are timbre categorizations into classes and/or families. The boundaries of such groupings can be better described by testing its mutual compabilities, which can be rendered in terms of the semiotic operations of blending (mélange) and sorting out (tri) (Zilberberg, 2004), as manifested by arrangement and orchestration techniques. At the maximal level of density, there are timbres related to unique and exclusive entities. These timbres are often labeled with anthroponyms. The analysis of empirical objects has shown that highly dense timbres trigger enunciative operations similar to those triggered by the formal apparatus of enunciation (Benveniste, 2006 [1974]). In this scenario, timbre does impose strong selection constraints onto its linguistic-melodic substrate, given that a swap of the timbre overlay can neutralize or even make null the authenticity effect generated by the enunciative illusion (Tatit, 2016). The results of the analyses show that, despite its wide variability range, the possible selection and combination of timbres are not unrestricted. The analysed data allow us to conclude that generic timbres (i.e. with low figurative density) behave as variants and can be freely swapped, while specific timbres (i.e. with high figurative density) behave as invariants and trigger an operation of commutation, in the glossematic meaning of these terms (Hjelmslev, 2006 [1943]). These findings relativize the assumption, detected in the literature review, that timbre is a variable freely chosen and combined in speech, popular song and music.

Keywords: semiotics, tone-colour, enonciation, song, voice. 


\section{Sumário}

Resumo $x$

Abstract $\quad$ xi

Introdução 1

1 Revisão de literatura $\quad 8$

1.1 Concepções gerais de timbre . . . . . . . . . . . . . . . . 8

1.2 O timbre em semiótica da canção . . . . . . . . . . . . . . . . 15

1.2.1 O timbre nos escritos de Tatit . . . . . . . . . . . . . 15

1.2.2 Desdobramentos ulteriores . . . . . . . . . . . . 20

1.3 Interpretação e debate . . . . . . . . . . . . . . . . . 25

1.3.1 Diretrizes teóricas gerais . . . . . . . . . . . . . . . 26

1.3.2 Balanço intermediário e plano de trabalho . . . . . . . . . 29

2 Timbre e categorização 34

2.1 Nomear e qualificar: categorizações ambivalentes . . . . . . . . . . . . 34

2.1.1 Categorização por nomeação . . . . . . . . . . . . . . 35

2.1.2 Categorização por qualificação . . . . . . . . . . . . . . 36

2.1.3 Qualidades e entidades: uma articulação possível? . . . . . . . . 37

2.2 Uma ferramenta de análise: a figuratividade . . . . . . . . . . . . . 37

2.2.1 Figuratividade e percepção: da figura do mundo para a figura do discurso . . . . . . . . . . . . . . . . . 39

2.2 .2 Do figurativo ao plástico . . . . . . . . . . . . . . . 45

2.3 Um dispositivo gradual: sistematizando os graus de figuratividade do timbre 49

2.3.1 Densidade figurativa e inteligibilidade . . . . . . . . . . . . 50

2.3.2 Densidade figurativa e graus de especificidade . . . . . . . . . 52

2.4 Advertências sobre o uso do esquematismo tensivo e suas diferentes possi-

bilidades de leitura . . . . . . . . . . . . . . . . . 58

2.4.1 Sobre a correlação inversa . . . . . . . . . . . . . . . 59

2.4.2 Sobre o uso da expressão "densidade figurativa" . . . . . . . . . . . 61

2.5 Cristalização timbrística como fenômeno discursivo . . . . . . . . . . 62

2.6 Balanço intermediário . . . . . . . . . . . . . . . 63

$\begin{array}{lll}3 & \text { Timbre e temporalidade } & 71\end{array}$

3.1 Pontos de partida . . . . . . . . . . . . . . . . . . 71

3.2 A temporalização do timbre em semiótica da canção . . . . . . . . . . . 73 
3.3 Uma proposta de reformulação . . . . . . . . . . . . . . . . . . . . . . . 74

3.4 Aspectualizando o envelope sonoro tímbrico . . . . . . . . . . . . . 78

3.4.1 Andamento e aspectualidade do timbre . . . . . . . . . . . 78

3.4.2 Extrapolações da noção de aspecto . . . . . . . . . . . . . . . 79

3.5 Precedentes do emprego da aspectualização a elementos do Plano da Expressão 80

3.6 Sobre a necessidade e a insuficiência do tratamento aspectual . . . . . . . 82

4 Triagens e misturas tímbricas $\quad 87$

4.1 Descrições morfologizantes e sintaticizantes de timbre . . . . . . . . . . 87

4.1.1 Dois modos de caracterizar um objeto: intra- e inter - . . . . . . . 88

4.1 .2 As relações na semiótica . . . . . . . . . . . . . . . . . 90

4.2 Sintaxe extensiva aplicada ao timbre: estágios de miscibilidade . . . . . . 99

4.2 .1 Fusão . . . . . . . . . . . . . . . . . . . . . . 100

4.2 .2 Mescla . . . . . . . . . . . . . . . . . . . 108

4.2 .3 Contiguidade . . . . . . . . . . . . . . . . . . . . . 116

4.2 .4 Separação . . . . . . . . . . . . . . . . . . . . . . . 124

4.3 Interpretação e debate . . . . . . . . . . . . . . . . . . . . . 129

4.3.1 Dialéticas da triagem e da mistura e práticas de rearranjo musical 129

4.3.2 Sintaxe extensiva e norma estética . . . . . . . . . . . . . . . 131

4.3.3 Fenômenos análogos . . . . . . . . . . . . . . . . . . . . . . 133

4.3.4 Sintaxe extensiva e especificação semântica intermediária . . . . 136

5 Timbre e breagem: operações enunciativas 145

5.1 Timbre e enunciação . . . . . . . . . . . . . . . . . . . . . 145

5.2 A enunciação e suas marcas . . . . . . . . . . . . . . . . . 146

5.2 .1 Definições canônicas . . . . . . . . . . . . . . . . . 146

5.2 .2 Enunciação e breagem sensível . . . . . . . . . . . . . . . . . . . 149

5.2 .3 Timbre como desencadeador de breagem sensível . . . . . . . . . . 151

5.2.4 Condicionantes da breagem sensível . . . . . . . . . . . . . . 153

5.3 Relações de (in)compatibilidade entre revestimento tímbrico e substrato linguístico/musical . . . . . . . . . . . . . . . . . 155

5.3 .1 Fala . . . . . . . . . . . . . . . . . . 157

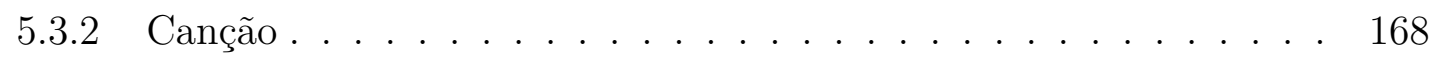

5.3 .3 Música . . . . . . . . . . . . . . . . . . . . . . . . . . 182

5.4 Discussão dos dados . . . . . . . . . . . . . . . . . . . . . . 190

5.4.1 Especificação do timbre e coerção combinatória ....... 190

5.4 .2 Timbre vocal e instrumental . . . . . . . . . . . . . . . . . . 191

5.4 .3 Prototipia timbrística . . . . . . . . . . . . . . . . . 191

5.4.4 Fenômenos análogos: typecasting . . . . . . . . . . . . 193

$\begin{array}{ll}\text { Conclusão } & 198\end{array}$

5.5 Síntese geral e contribuições da pesquisa . . . . . . . . . . . . . 198

5.6 Limites do trabalho e desiderata . . . . . . . . . . . . . . . . 203

5.7 Últimas palavras . . . . . . . . . . . . . . . . . . . . . . . 204

Referências bibliográficas $\quad 222$ 


\section{Introdução}




\section{Introdução}

A presente pesquisa pretende preencher certa lacuna de estudos semióticos dedicados à significação do timbre. Como objetivo primário, coloca-se a compreensão dos mecanismos de significação e das estratégias discursivas subjacentes à seleção e à combinação de timbres em discursos verbais, musicais e cancionais. Um pouco à maneira do que ocorreu com o desbravamento de novos mundos de outrora, a descoberta do timbre pelo semioticista revela, na verdade, vastos territórios de investigação já sitiados por especialistas de áreas diversas, como a acústica, a psicoacústica, a organologia, a fonoestilística, a pedagogia de performance musical, a foniatria, a filosofia estética, entre tantas outras. Frente à diversidade de tribos que ocupam o continental campo de estudos do timbre, cabe à semiótica pôr em uso seu arsenal epistemológico e conceitual caso queira conquistar seu quinhão. A despeito do marco pioneiro fincado pelo seminal $O$ grão da voz (Barthes, 1981), a questão do timbre recebeu pouca atenção por parte dos semioticistas, mais voltados à época em desbravar outros terrenos de pesquisa ou mesmo consolidar a arquitetura conceitual de uma teoria geral da significação. Nesse cenário, o presente trabalho visa reintegrar à semiótica discursiva um território por ela abandonado às disciplinas circunvizinhas. Deixando para trás o alumbramento inicial da exploração ensaística, é preciso partir em busca de instrumentos operacionais que permitam mapear de maneira sistemática a significação do timbre. Apesar de mais frequentemente associado à voz, ele será abordado aqui sob um enfoque mais amplo, a saber, como identificador de fonte sonora.

Tal problemática suscita usualmente duas atitudes distintas. Por vezes, ela é relegada a segundo plano como questão secundária indigna de interesse: "o problema do reconhecimento das significações imanentes da matéria sonora não deixa de existir negando-o." (Sad Levi, 2018,p. 6, tradução nossai ${ }^{\text {) }}$. Em outros momentos, ela é tratada como obstáculo intransponível, esfinge sonora que devora todos aqueles que, paralisados diante de sua complexidade, não logram decifrá-la. O presente trabalho se propõe a inverter essa perspectiva, abordando de frente a questão. Sob novas lentes analíticas, um objeto já conhecido passa a ganhar novos contornos e nuanças. Assim como os mais novos desenvolvimentos tecnológicos permitem ultrapassar limites inimagináveis para 
as gerações anteriores, também os novos desenvolvimentos teóricos viabilizam soluções analíticas originais que se encontravam até então além do horizonte de reflexões. É nesse quadro que se justifica o emprego ostensivo do esquematismo tensivo como ferramenta de análise.

A bússola teórico-epistemológica dessa empreitada é fornecida pela semiótica discursiva, traçando um longo arco que parte do pensamento dos linguistas Ferdinand de Saussure, Louis Hjelmslev, passa pelas reflexões de Émile Benveniste sobre a enunciação, cruza o edifício teórico da semiótica discursiva construída por Algirdas Julien Greimas e colaboradores e desemboca nos desdobramentos mais recentes do assim chamado "ponto de vista tensivo" conforme avançados por Jacques Fontanille e, sobretudo, Claude Zilberberg. Por observar o sentido para além das linguagens de manifestação particulares, a semiótica discusiva conta com um ferramentário conceitual robusto para tal tarefa e se encontra, com isso, em plenas condições de reconquistar seu espaço de direito no território do timbre.

Dado seu objeto de análise, a investigação a ser desenvolvida não tem outra escolha a não ser assumir seu caráter mestiço, miscigenando um aporte teórico de herança linguística e um terreno de reflexão musical por excelência (embora não exclusivamente). Como ocorre a toda mestiçagem, seu resultado sofre de certo não-pertencimento ambíguo, simultaneamente estranho às duas fontes que lhe originam.

Aqueles à margem musical do timbre podem não se reconhecer nessas reflexões, ressentindo-se talvez de certas ausências de uma longa tradição de pesquisa musicológica. A esses, também soará como dissonante e intrusiva a aplicação de um arcabouço teórico construído majoritariamente sobre a base epistemológica da linguística estruturalista. Sob esse ângulo, é inevitável - e mesmo compreensível - que se questione a relação custo-benefício implicada na aquisição de um novo aporte teórico.

O mesmo desconforto acometerá também o semioticista que, mal a reflexão adentra territórios musicais, já recua imediatamente alegando completo desconhecimento sobre o tema. Curiosamente, uma tal atitude de precaução não tem impedido semioticistas sem formação específica em artes plásticas, cinema, fotografia etc. de praticar semiótica visual. Essa constatação deve servir menos de advertência do que de convite àqueles que, não se crendo especialistas em música, abandonam toda esperança antes mesmo de entrar pelas sendas do timbre.

Renunciando desde já à exigência de agradar gregos e troianos, uma pesquisa mestiça como a que se apresenta aqui alimenta, apesar de tudo, o desejo de encontrar intersecções possíveis entre essas duas grandes áreas do conhecimento que se entrecruzam no timbre. De um lado, a semiótica testa e refina seus instrumentos de análise a partir dos resultados providos pelas linguagens particulares. De outro lado, os estudos musicológicos podem e devem usufruir do poderio analítico da semiótica para conseguir superar a coleção 
de anedotário estético. O potencial de benefícios proporcionados pela interlocução entre esses domínios só não supera sua indisposição mútua.

Até o momento, fala-se como se o timbre fosse um objeto exclusivamente musical. Essa é uma falácia que precisa ser desmantelada desde já. De fato, não se pode aceitar passivamente essa premissa, a não ser que se esteja disposto a aceitar anúncios sonoros de metrô e aeroporto e locuções radiofônicas como música - e talvez bem poucos estariam inclinados a isso. O timbre é um objeto semiótico por excelência, pois perpassa diferentes linguagens de manifestação e, sendo comum a todas elas, não pode ser estudado por nenhuma delas exclusivamente sem acabar mutilando suas outras facetas. Somente a semiótica está em condições de atravessar todos esses domínios, pois não se limita a examinar esse ou aquele objeto particular, mas sim os mecanismos de significação que lhe subjazem. A semiótica discursiva assume que não há sentido musical, literário, pictural etc. Ao contrário, o sentido deve ser tratado como um fenômeno transversal e constante à revelia de suas variadas manifestações superficiais (Greimas \& Courtés, 2012 [1979], p. $434)$.

Também singularizam esse referencial teórico os princípios de análise interna e imanente. São eles que garantem a autonomia do timbre enquanto objeto de análise em detrimento de suas contingentes condições materiais de produção. Isso permite superar o realismo ingênuo que, não raramente, impregna o comentário de apreciação estética do timbre. Aqui, as remissões ao mundo real e às intenções do sujeito esmaecem em segundo plano em benefício da observação dos mecanismos estruturais geradores de significação. Reverberando argumentos já empregados pelo próprio F. de Saussure, mas também por A. J. Greimas, a análise imanente prima por não tomar o objeto de análise como pretexto para falar de outra coisa - como se observa não raramente em algumas abordagens de cunho sociologizante e/ou psicologizante. O objeto de análise deve ser o fim, e não um meio.

Outra diretriz epistemológica diretamente relacionada a essa diz respeito ao caráter sistêmico visado pela análise. A semiotização dos dados procura sempre explicitar a organização de um sistema subjacente, gerador das formas manifestadas em superfície. Sob esse ângulo, não interessa à semiótica discursiva se debruçar sobre epifenômenos contingenciais. Por mais fascínio que desperte, a aura singularíssima deste ou daquele timbre não pode obliterar a busca por regularidades generalizáveis em um sistema. A esse respeito, vale lembrar as palavras de Lopes (2005) quando, rememorando as bases do pensamento saussuriano, declara que "não são as 'coisas' que fazem sentido, e sim as relações entre elas." (2005, p. 206). Simples e descompromissado, esse corolário sintetiza bem o quadro epistemológico que norteia o presente trabalho sem enfastiar o leitor com uma longa e exaustiva exposição sobre os princípios saussurianos de negatividade do valor 
linguístico, de arbitrariedade e de linearidade do signo, bem como a noção de dependência e o primado da relação sobre os termos herdados da glossemática hjelmsleviana - cada qual merecedor de mais tinta do que essa introdução pode lhes dedicar.

Como já se afigura claro a essa altura, uma experiência de leitura otimizada desta tese exige sólidos conhecimentos prévios sobre os fundamentos da semiótica discursiva, conforme alicerçados pelas obras-chave da área ${ }^{1}$ e difundidos na literatura de divulgação circulante em contexto brasileiro. ${ }^{2}$ Tanto quanto possível, o emprego de jargão da área foi reduzido e as ferramentas analíticas indispensáveis foram explanadas em linguagem presumivelmente acessível a um público mais amplo. Apesar de todos os esforços, é inevitável que um trabalho científico interpele com mais veemência um público-alvo preferencial, notadamente os pares de área.

Com efeito, tal escolha vem cobrar seu preço em concisão e agilidade textual. Para o semioticista mais experiente, certas paráfrases e digressões soarão redundantes, fastidiosas e mesmo suprimíveis. Esse movimento de condensação e expansão, tão caro à elasticidade do discurso, é inevitável diante de um texto que ousa querer se dirigir ao mesmo tempo a dois perfis de leitores distintos. Isso implica certo risco de incompreensão que, todavia, vale a pena correr na esperança de - no melhor dos mundos - conferir maior alcance às ideias em desenvolvimento.

Seus primeiros passos se iniciam em uma revisão bibliográfica crítica sobre o timbre, com especial ênfase aos estudos semióticos em território nacional (cf. Cap. 1). Nele, observa-se um crescente interesse pelo tema, ainda que abordado de maneira algo fragmentária e tangencial. A emergência de tais explorações esparsas e ainda fracamente articuladas evidencia a necessidade de recensear, coletar, sintetizar e consolidar os avanços conquistados pela pesquisa semiótica até o presente momento para, a partir daí, propor algum encaminhamento às problemáticas deixadas em aberto. Desse levantamento, serão extraídas as principais direções de pesquisa a ser tomadas.

Esse exercício de síntese revela o potencial de aplicação do conceito semiótico de figuratividade para melhor elucidar o timbre em sua função de remissão à fonte sonora. As condições e consequências dessa prospecção serão desdobradas em pormenor no capítulo 2. Uma leitura crítica da figuratividade na arquitetura teórica da semiótica mostra pontos de contato proveitosos entre a função de "impressão digital sonora" comumente atribuída ao timbre e o efeito de sentido de "realismo" criado pela iconização, tão cara à estética do romance realista francês, mas também à fotografia, às artes plásticas e a certos ramos da

\footnotetext{
${ }^{1}$ cf. Greimas (1974, 1975b,a, 1976 [1966], 2002, 2014 [1983]); Greimas et al. (1977); Greimas \& Courtés (1986, 2012 [1979]); Fontanille \& Zilberberg (2001); Bertrand (2003); Fontanille (2007); Zilberberg (2004, $2006 a, b, 2007,2011 a, b, 2012)$.

${ }^{2}$ cf. Fiorin (1989, 1999, 2008a); Barros (2002, 2007, 2014b); Lopes (1997); Tatit (2001, 2002, 2004b,a, 2007, 2016); Saraiva \& Leite (2017).
} 
computação gráfica.

O aparato teórico permite enxergar que o reconhecimento de uma identidade exclusiva por trás do timbre corresponde a um grau superlativo de uma escala gradual de especificidade. A progressiva rarefação figurativa do timbre produz identidades inespecíficas, observáveis nas designações por classes e/ou famílias (de instrumentos musicais, por exemplo) e, no limite, nas adjetivações genéricas sobre o caráter do objeto sonoro. Essa escala gradual pode ser segmentada em três grandes patamares, a saber, um grau mínimo, um grau intermediário e um grau máximo de especificação. Cada um demarca, em linhas gerais, grandes campos de investigação sobre o timbre a serem abordados cada qual em capítulo próprio do presente trabalho.

Contemplando o timbre em seu grau mínimo de especificidade, o capítulo 3 busca traduzir semioticamente as descrições de caráter temporalizante já avançadas em outras áreas. Adentrando um terreno dominado pelas mensurações laboratoriais, a intervenção semiótica procura apurar em que medida a estrutura temporal interna do timbre interfere em sua seleção e combinação em textos musicais. Quando se passa ao patamar intermediário de especificação, os timbres se deixam categorizar em classes e famílias, organizadas em torno de um membro prototípico. Sobre esse pano de fundo, o capítulo 4 procurará verificar como se dá essa distribuição valendo-se para tal do instrumental analítico da vertente tensiva da semiótica. A análise se justifica assumindo a hipótese de que um dos fatores para a seleção e a combinação de timbres é a afinidade mútua entre membros de classes/famílias timbrísticas. Avançando essa linha de raciocínio a um degrau mais profundo, a seleção e combinação de timbres nos textos assumiria maior força coercitiva quando este é investido de um grau máximo de especificação. Os aspectos teóricos e metodológicos de tais restrições serão pormenorizados no capítulo 5. Nele, tais coerções combinatórias serão testadas observando os diferentes graus de compatibilização entre o revestimento timbrístico e seu respectivo substrato linguístico, musical e/ou cancional.

Mais do que metodologias de análise definitivas, essas três perspectivas se apresentam antes como frentes de trabalho ramificadas a partir de um eixo conceitual central, constituído pela escala de densidade semântica e figurativa. Abdicando à pretensão de avançar novas taxonomias - inexoravelmente fadadas à obsolescência - essa estratégia de ataque visa nada mais do que mapear em grandes linhas o território do timbre, cujos contornos restam sempre por ser refinados. Mãos à obra.

\section{Citações traduzidas no original}


i“[...] el problema del reconocimiento de las significaciones inmanentes de la materia sonora no deja de existir negándolo". (Sad Levi, 2018,p. 6) 
Capítulo 1

REVISÃo DE LITERATURA 


\section{Capítulo 1}

\section{Revisão de literatura}

\subsection{Concepções gerais de timbre}

No senso comum, timbre é definido como a propriedade responsável por identificar a fonte de um evento sonoro qualquer. Outras definições apresentam o timbre como a qualidade perceptiva que distingue dois sons de igual altura, duração e intensidade. Não raramente, encontra-se também a definição de timbre como "cor do som".

A aparente simplicidade dessas definições esconde uma série de questões intrigantes sobre o timbre que o singularizam em relação aos demais parâmetros sonoros de altura, duração e intensidade. Estes se deixam mensurar respectivamente em Hertz, milissegundos e decibéis. Em contrapartida, o cenário se afigura diferente para o timbre: qual seria seu correlato acústico? Como ele pode ser mensurado?

Desde os estudos pioneiros de Helmholtz, a percepção de timbres é atribuída ao envelope espectral, resultante das microvariações de intensidade das frequências parciais. Para mapear as diferentes possibilidades resultantes daí, a pesquisa na área da acústica encampou um extenso aparato laboratorial (Grey, 1975, 1978; Huron, 2001; Mintz, 2007; Seashore, 1967). Por sua vez, a foniatria e os estudos sobre voz cantada buscam entender como se dá a produção de determinados tipos de timbre vocal olhando para as condições fisiológicas do aparelho fonador humano (Goldhan, 1995; Sundberg, 1977, 1994, 1999, 2007; Sundberg \& Thalén, 2001; Sundberg \& Rossing, 1984, 1990). Mesmo um pesquisador canônico na área da psicologia musical como Carl Seashore (1967) coloca suas dúvidas sobre as dificuldades de entender o timbre somente a partir de dados acústicos:

As diversas notações objetivas apresentadas [nesse capítulo] não mostram nada sobre o timbre. É totalmente reconhecido que esse quarto fator do canto é, de longe, a característica mais importante da voz, mas também é o fator mais complicado (Seashore, 1967, p. 283, tradução nossa ${ }^{\text {ii }}$ ). 
Em artigo sintomaticamente intitulado "Why is musical timbre so hard to understand”, Krumhansl (1989, p. 44) aponta diversos problemas com a definição canônica de timbre e questiona se a distribuição da energia espectral acústica estaria de fato desconectada de outros mecanismos de percepção de alturas. Mesmo as pesquisas empíricas centradas estritamente na constituição física do timbre interrogam em que medida é possível isolar por completo sua base acústica. Conforme testemunha Mintz (2007,p. 24), o efeito do envelope espectral sobre a percepção de altura e intensidade era constatado já nos primórdios das pesquisas laboratoriais sobre o timbre. A insuficiência das evidências puramente acústicas se manifesta também nas reflexões sobre a voz do semiólogo Dominique Ducard (2002):

Pode-se identificar o timbre característico de um cantor através da restituição bem deformada e apesar da distorsão do espectro de frequências. Com efeito, o timbre é um fenômeno complexo que não se reduz ao espectro acústico e depende igualmente da evolução dinâmica dos sons (ataque ou decaimento), isto é, variações de suas intensidades no tempo. Cada voz conserva uma cor que lhe é particular, mesmo quando, por filtragem, as intensidades relativas das [frequências] parciais afetam sua qualidade. (Ducard, 2002 , p. 41-42, tradução nossaiii)

O comentário acima se deixa relacionar a um fenômeno bem conhecido de nossa vivência cotidiana: em um telefonema, somos capazes de reconhecer nosso interlocutor pelo timbre, mesmo quando esse é filtrado e, em certa medida, transfigurado pelo aparato eletromagnético do telefone. O mesmo fenômeno ocorre com a amplificação pelos altofalantes de um show ou de um sistema de avisos no aeroporto. Embora não dispense em absoluto a configuração de seu envelope espectral, existem razões para crer que o reconhecimento e a categorização de timbres vai além dos limites de sua modelagem física, conforme reconhece mesmo um musicólogo e compositor de incontestável familiaridade com as experimentações acústicas como Pierre Schaeffer (2002):

Por mais que vejamos uma corda vibrar, a relação não é muito evidente entre esse fuso, que a estroboscopia analisa para o olho, e a unidade sonora tão convincente que se anuncia ao nosso ouvido. De um gongo, de um trompete, não se vê nada (Schaeffer, 2002 ,p. 161, tradução nossa ${ }^{\text {iv }}$ ).

Semelhante objeção é encontrada também na margem propriamente linguística da discussão. Para Herman Parret (2002, p. 50), a divisão componencial do timbre realizada 
pelo foneticista John Laver é reducionista e fracassa em explicar a emergência de formas tímbricas e sua significação.

Outro caso emblemático é o estudo sobre atitudes sociolinguísticas e percepção de vogais conduzido por Nancy Niedzielski (apud Eidsheim, 2008). A pesquisadora exibiu uma mesma gravação de um discurso a dois grupos de sujeitos. Em um dos grupos, os integrantes foram previamente informados sobre a origem social e geográfica do falante em questão; no outro, nenhuma informação foi dada. Após a exibição, foram solicitados dos participantes julgamentos sobre as vogais que eles escutaram na gravação. Os dados obtidos por esse experimento mostram que a crença prévia sobre a origem do falante enviesou decisivamente a percepção das vogais por parte dos sujeitos, embora eles tenham sido expostos ao mesmo material linguístico. Niedzielski sintetiza os resultados do experimento atestando que "o ouvinte utiliza informações sociais na percepção da fala" (1999: 62, apud Eidsheim, 2008, p. 10).

Contrariando certa crença corrente no senso comum, o estudo citado mostra como a percepção (linguística, nesse caso particular) não é uma captura neutra de substratos sensoriais igualmente neutros. Mesmo quando se trata de sujeitos com alto grau de treinamento musical, a percepção de timbre não está imune a crenças enviesadas do sujeito. É o que demonstra o trabalho de Eidsheim (2008) ao evidenciar como certo viés étnico-racial e social leva professores de canto erudito a associar o timbre de uma mesma cantora a estilos por vezes diametralmente opostos. Isso permite redimensionar o peso atribuído para o substrato fisiológico do timbre e seus efeitos na apreensão perceptiva. É inegável que a pesquisa laboratorial faz um trabalho indispensável de encampar as modulações das ondas sonoras. No entanto, o semioticista ainda se sente impelido a ir além e abordar também a significação que emerge daí.

Especificamente nos estudos da linguagem, a modulação timbrística da voz é considerada um dado paralinguístico de natureza suprassegmental. Ela pode predicar diferentes atitudes dos falantes com relação ao seu enunciado ou ao seu interlocutor. Analisando aspectos articulatórios na produção dessas modulações, Poyatos (1991) distingue dez tipos diferentes de qualificadores para a voz.

Por sua vez, König \& Brandt (2006,p. 120) reportam que falantes de Tzeltal, idioma de matriz Maya falado no México, utilizam o registro de "voz de cabeça"1 para expressar reverência frente a seu interlocutor e seu uso pode se espraiar por toda a conversação. Os mesmos autores relembram também que, em um bom número de línguas do mundo, a voz sussurrada ${ }^{2}$ é usada para expressar confiança, segredo e confidencialidade (2006, p. 120). Não é difícil reconhecer como, na qualidade de marcador paralinguístico, o

\footnotetext{
${ }^{1}$ Essa designação é emprestada pelos autores dos métodos de ensino e aprendizagem de canto

${ }^{2}$ Para detalhes sobre os aspectos articulatórios, cf. Eckert \& Laver (1994) e os diagramas compilados em: < http://www2.ims.uni-stuttgart.de/EGG/page10.htm >
} 
sussurro re-enquadra tanto a relação dos sujeitos da enunciação entre si quanto a relação deles com o teor do enunciado.

Também do ponto de vista estritamente linguístico, essa função tem sido considerada de pouca relevância, pois a matéria vocal não participa na construção da estrutura gramatical das línguas naturais. Mesmo no estudo da fonologia, a descrição do sistema fonológico e seus processos prescinde, em larga medida, da base material constituída pela voz. Essa opção metodológica é assim sumarizada por Parret (2002): "Os grandes estruturalistas - Jakobson, Hjelmslev, Troubetzkoy - são solidários quanto a essa 'colocação entre parênteses' da voz, e eles não hesitam em tomar a axiomática saussuriana como testemunho." (2002, p. 52, tradução nossa ${ }^{v}$ ).

Para além dos autores canonizados na linguística, outros estudos no campo da fonoestilística se ocupam em correlacionar variáveis pragmáticas (valor atitudinal, emotividade, força perlocucional etc.) e sociolinguísticas (marcadores de identidades sociais) a padrões suprassegmentais verificados na análise acústica (cf. especialmente Léon, 1993). Porém, mesmo nesses casos em que a substância vocal é posta em primeiro plano, nota-se que a função de remissão à fonte sonora propriamente dita é abordada apenas indiretamente e parece constituir uma espécie de "penumbra conceitual" das inúmeras variáveis acústicas e pragmáticas investigadas por tais estudos. Desde as reflexões sobre o "grão da voz" consagradas por Roland Barthes (1981), sabe-se o quão íntima é a relação do timbre com o corpo sensível que lhe dá origem. Ao refletir sobre um possível projeto de investigação fonoestética, Parret (2010) nota o caráter irremediavelmente somático da vOZ:

O que é percebido e sentido quando uma voz nos atinge não é uma voz 'liberta' do corpo que a emite, mas sim $o$ próprio corpo feito voz. E, no entanto, a voz é o indecidível do corpo. Ela nasce dele mas esquece-o, apaga-o. (2010, sem paginação, grifos no original, tradução nossavi ${ }^{\mathrm{vi}}$.

Essa observação sintetiza de maneira lapidar um entendimento corrente no senso comum ao mesmo tempo que o traduz em termos fenomenologizantes. Ao fazer avançar a ideia de "corpo-feito-voz" (corps fait voix), Parret (2002, 2010) concilia dois atributos do timbre aparentemente incongruentes, a saber, sua ancoragem à fonte sonora e sua autonomia semiótica.

Resolver essa antinomia é um dos grandes desafios de um estudo semiótico voltado para o timbre. Afinal, como conceptualizar essa remissão à fonte sonora sem reduzir o timbre a ela? Do ponto de vista de uma semiótica discursiva, essa problemática ganhará ainda um agravante: como trabalhar adequadamente a questão da fonte sonora sem contradizer os princípios de imanência e análise interna que alicerçam a disciplina desde 
o gesto inaugural de sua fundação (Greimas, 1976 [1966])? Mais do que mero capricho intelectual, é preciso frisar como essa questão da ancoragem corporal à fonte sonora é uma característica peculiar do timbre que não pode ser desdenhada sem maiores consequências. Um exemplo disso é vislumbrar a situação inversa: uma voz que não possa ser associada a nenhum corpo originário. É o que fez o pesquisador Thomas Macho (2006) a partir de uma perspectiva filosófica:

Tão logo uma voz não possa mais ser relacionada à presença nem de uma pessoa concreta, nem de um lugar e nem de um corpo; [...] ela [a voz] tem um efeito mais poderoso e mais ameaçador do que qualquer ruído inesperado. Testemunhas disso são os muitos relatos da história das religiões e dos arquivos da psiquiatria moderna: deuses e demônios se manifestam mais frequentemente em vozes sem corpo do que em visões. (Macho, 2006 ,p. 131, tradução nossavii)

Na mesma linha de raciocínio, Grover-Friedlander ([s/d]) faz uma interessante comparação entre o caráter acorporal da voz na ópera e no telefone, sendo este último "um terreno de acorporeidade onde a suspensão do visual e do corporal é concebida com êxito". ([s/d], p. 205-206, tradução nossaviii). Por inusitada que seja, tal comparação põe em evidência o quão imperativa é a ancoragem do timbre à fonte sonora. Para além desses cenários de escuta já profundamente estetizada e culturalizada, é na audição em seu "estado bruto" e em seu papel de mapeamento do mundo circundante que tal ancoragem do timbre se faz sentir com mais veemência, como nos mostra o musicólogo Jamie Kassler ([s/d]) em estudo dedicado à audição e ao abuso sônico:

Em sua função biológica, o sistema auditivo é tanto o sentido da ameaça quanto um prenúncio do futuro ("o que está acontecendo como um indicador do que provavelmente acontecerá"). A audição nos alerta de mudanças atrás de nós ou à distância, por assim dizer, em lugares que não podemos ver e, desse modo, nos prepara para entrar em ação. (Kassler, [s/d] , p. 327, tradução nossaix ${ }^{\text {ix }}$

Enquanto a percepção de intensidades e suas variações nos ajuda a estimar a distância e o deslocamento das fontes sonoras com relação a nós, o timbre desempenha um importante papel de identificar a natureza dessas fontes sonoras. Seria razoável assumir que essa atribuição de "papéis" não é sem consequência. Tiremos todas as consequências da situação posta em cena aí. Em princípio, o senso de ameaça desencadeado por um evento sonoro de intensidade crescente e súbita poderia ser posto em suspenso, caso o timbre identifique uma entidade categorizada pelo ouvinte como inofensiva. Essa seria 
a situação de um banhista que reconhece, pelo marulho às suas costas, uma onda se erguendo no mar. Não teria a mesma sensação de tranquilidade um pedestre que cruza uma movimentada avenida na cidade de São Paulo.

Para além de elucubrações hipotéticas, visamos aqui sublinhar o quão irremediavelmente atrelado à identificação de entidades no mundo é o timbre. Ultrapassando o terreno das assinaturas sonoras de instrumentos musicais exclusivos e de orquestrações inusitadas, tal problemática da remissão sonora se impõe mesmo nas situações mais banais do cotidiano. Exemplo contundente disso é trazido em artigo da pesquisadora Cornelia Fales (2002) com o sugestivo título "The paradox of timbre":

Confiantes de sua acuidade auditiva, ouvintes se sentem ligados diretamente e de maneira aural a uma fonte no mundo acústico. A orientação à fonte da audição do ambiente é tão forte que ouvintes projetam a premissa fundamental de sua lógica auditiva sobre os dados que eles devem interpretar, e [projetam] a sensação auditiva subjetiva sobre o mundo de fontes até que o som se iguale à fonte. Nós dizemos 'eu escuto um grilo' - e não - 'eu escuto um som que pode indicar a presença de um grilo' (Fales, 2002 , p. 63, tradução $\left.\operatorname{nossa}^{\mathrm{x}}\right)$

Todo esse itinerário de semiotização dos estímulos sonoros é sincopado para conferir-lhes já alguma semantização. De um ponto de vista estritamente conceitual, constatar que se ouve um grilo é fundamentalmente distinto de ouvir um objeto sonoro que pode indicar a presença de um grilo. Porém, exceto em exercícios de escuta sensibilizada, essas fases de apreensão e identificação raramente são dissociadas. É exatamente tal assimilação automática entre objeto sonoro e sua fonte que testemunha a poderosa e invisível atuação do timbre. Assim sendo, uma das vocações de um estudo semiótico é, entre outras, desnaturalizar o timbre esmiuçando em termos concretos o que acontece nesse percurso.

É preciso considerar também que, eventualmente, tal identificação pode não ser bem sucedida. Na paisagem sonora de nosso dia-a-dia, estamos expostos a uma infinidade de objetos sonoros cujos timbres indistintos não são suficientemente prototípicos para identificar entidades únicas. Se essa indistinção não traz consequências graves na maioria das situações triviais, ela impõe sérios obstáculos para o trabalho da etnomusicologia. Quando se trata de descrever práticas musicais ainda pouco documentadas, simplesmente nomear um instrumento musical desconhecido é pouco produtivo e não há outra escapatória senão tentar descrever seu timbre pormenorizando os detalhes de sua anatomia e seu material na esperança de conseguir, assim, dar conta de sua coloração timbrística: 
Porém, o aspecto qualitativo representa ainda uma fonte de dificuldades para uma transcrição completa. A indicação do instrumento por si só parece insuficiente quando o timbre é, no caso da valiha ${ }^{3}$, tratado como elemento fundamental de variações e de estilização do repertório. Uma solução possível consistiria em caracterizar a "paleta sonora" do musicista depois que o etnomusicólogo tenha determinado-a previamente, tomando em consideração certos pontos determinantes na produção do som. A escolha dos materiais de fabricação (bambu, aço, cobre?), dos dispositivos particulares de execução (elástico, cordas duplas ou triplas, microcontato?) deve ser especificada.(Razafindrakoto, 1999 , p. 16, tradução nossa ${ }^{\mathrm{xi}}$ )

Mesmo reconhecendo os avanços propiciados pelo aparato tecnológico no registro e na descrição quantitativa de tais práticas musicais, Razafindrakoto (1999) lamenta a dificuldade de apreender a dimensão estética e o poder expressivo das variações timbrísticas. Embora seja mais facilmente reconhecível no trabalho encampado pela etnomusicologia, esse problema emerge, na verdade, por toda parte onde o timbre marca presença e um indício disso é a ausência de um sistema de notação universal para esse parâmetro sonoro.

A esse respeito, Reed (2005) faz observar que "nenhuma complexidade notacional pode dar conta da complexidade extrema e relativamente imprevisível e do fluxo no timbre musical [...]" (2005, p. 21, tradução nossa xii). Ainda sobre essa questão, o autor atribui tal dificuldade à propriedade do timbre de remeter a entidades ditas "extramusicais". Sem esmiuçar suas concepções sobre as fronteiras entre o musical e o extramusical, vale ainda frisar que a concepção de corporeidade (embodiment) vocal trabalhada por esse autor (2005 , p. 50-69) se coaduna em larga medida com a concepção de "corpo-feito-voz" de Parret (2002) já mencionada anteriormente. ${ }^{4}$

Embora pareçam não-relacionadas em um primeiro momento, tanto a ausência de notação específica quanto a remissão a entidades do mundo natural se deixam articular a uma mesma problemática: o universo de timbres como conjunto infinito e não-discreto. Assumindo que existem tantos timbres quanto sejam as suas fontes sonoras possíveis, chega-se a um impasse: como elaborar um sistema de notação capaz de dar conta de um inventário aberto? Supondo que fosse viável, em que medida tal sistema de notação de timbres construído aos moldes daqueles já existentes para os parâmetros de altura e duração poderia descrever satisfatoriamente seus mecanismos de produção de significação?

É por ir em busca da colocação em discurso do timbre que uma investigação semiótica se vê obrigada a conectar todos esses pontos e conferir-lhes uma explicação coerente. Quais ferramentas conceituais poderão socorrer o semioticista em tal tarefa?

\footnotetext{
3 Trata-se de uma espécie de cítara metálica utilizada na música de habitantes de Madagascar.

${ }^{4}$ Cf. p. 11 acima.
} 
Para partir em busca de soluções satisfatórias, é necessária uma incursão mais aprofundada sobre o terreno já conquistado pelos estudos especificamente semióticos.

\subsection{O timbre em semiótica da canção}

\subsubsection{O timbre nos escritos de Tatit}

Desde seus primeiros momentos (Tatit, 1986), a Semiótica da Canção vem propondo tratar a canção como objeto sincrético constituído pela simbiose orgânica entre letra e melodia. Uma das grandes conquistas dessa proposta consiste em explicitar como os componentes verbal e musical da canção popular partilham dos mesmos mecanismos de produção de significação. Na ausência de instrumentos de análise projetados especificamente para esse objeto, os estudos sobre a canção vigentes até então se viam forçados a contemplar apenas uma dessas facetas, tomando de empréstimo metodologias e conceitos ora da análise literária, ora da musicologia. Lançando mão do ferramental teórico da semiótica discursiva, nomeadamente as contribuições de Algirdas Julien Greimas \& Courtés (2012 [1979], 1986); Greimas (1976 [1966], 2002) e Claude Zilberberg (2006a,b, 2011a), Tatit (1986, 1997, 2002, 2004b, 2007, 2010) demonstra como o comportamento ritmico-melódico da palavra cantada e os semantismos portados pela letra remontam, no fundo, a uma mesma configuração semiótica de base, descritível em termos de transformações narrativas e oscilações tensivas. O rendimento analítico de tal abordagem é atestado na ampla aplicação em análise de inúmeras composições do cancioneiro popular nacional (cf. especialmente Tatit, 2002). Para definir o assim chamado "núcleo de identidade" da canção, esses estudos privilegiaram os parâmetros musicais de altura e duração e sua relação com a letra. No entanto, afirmar que o timbre não esteve presente no horizonte dessas reflexões seria um erro. É o que revela uma leitura mais atenta dos escritos de Luiz Tatit.

Referido frequentemente pelo termo genérico "voz", o timbre é atribuído a duas funções: marca do intérprete na canção e elemento livremente variável. Essas duas características do timbre aparecem condensadas com precisão quase didática em Tatit (1997): “[...] o timbre principal, a voz, é um traço metonímico do intérprete a ser projetado livremente sobre a obra sem que haja também qualquer orientação prévia." (1997, p. 158, grifos nossos). Pela sua formulação concisa, esse excerto é particularmente fértil para entender a concepção de timbre corrente em semiótica da canção até o presente momento.

Em primeiro lugar, tomemos seu caráter de livre variável. Falando em termos gerais, assume-se normalmente que o timbre não participa da significação de nossas interlo- 
cuções verbais cotidianas. A título de exemplo, tomemos ao acaso um enunciado qualquer: "O dia está ensolarado". Como quer que seja analisada a semântica desse enunciado, admite-se em princípio que seu significado independe dos mais diversos revestimentos timbrísticos que podem vir a materializá-lo.

Se isso é ponto pacífico nas situações cotidianas de interlocução oral, o mesmo haverá de ser válido também para o domínio da canção, uma vez que ela nasce da estabilização rítmica e melódica das inflexões entoativas da fala cotidiana (cf. Tatit, 2010) e com ela partilha o mesmo suporte vocal. Essa relação é explicitada por Luiz Tatit lançando mão da oposição conceitual entre forma e substância cunhada por Louis Hjelmslev (2006 [1943]): "Note-se que não se pode pensar em melodia de canção sem aproximá-la da entoação linguística, já que ambas manifestam um fazer somático fundado numa substância de expressão vocal." (Tatit, 1997, p. 118, grifos nossos). Embora mencionada de maneira apenas tangencial, não pode passar despercebida aqui a ideia de "fazer somático" executado pela voz. Realçar sua ancoragem somática não é um gesto sem consequência. Ao contrário, é por esse resíduo corporal que se pode reconhecer o lastro enunciativo do timbre de voz, conforme esclarece esse autor nos seguintes termos:

No caso da canção, esses fenômenos de presentificação enunciativa são ainda mais acentuados em virtude da necessária interpretação de um cantor que literalmente recompõe a obra a cada nova execução. Além disso, a voz e a melodia se sobressaem, respectivamente, como substância e forma sonoras, cujas unidades se constituem de temas ou frases bem além das dimensões silábicas. (Tatit, 2007,p. 256, grifos nossos)

Não é fortuita essa reincidência à distinção conceitual entre forma e substância para declarar o estatuto de elemento variável da voz. Nunca é demais recordar que, segundo o pensamento de Hjelmslev (2006 [1943]), a primeira compreende as invariantes e a segunda compreende as variantes de uma estrutura semiótica (2006 [1943], p. 65-77). Alocar a voz ao papel de elemento da ordem do substancial e do variável, como o fez Tatit, e não tomá-la em consideração de maneira alguma são posturas absolutamente diferentes. Em uma recensão crítica da disciplina, essa diferença não pode ser negligenciada. Ao contrário, tal tomada de posição se coaduna perfeitamente com a formulação teórica de Hjelmslev (1991) segundo a qual a substância só existe como consequência inelutável da instauração da forma (1991, p. 47-79).

Ademais, o excerto em questão coloca em evidência ainda outra importante propriedade da linguagem da canção. Assim como as demais artes que dependem de performance, a canção também exige a mediação corporal de um sujeito no referido momento 
de "presentificação enunciativa". Enquanto a dança e o teatro se valem da gestualidade e do deslocamento topológico de cabeça, torso e membros superiores e inferiores, na canção, é a voz do intérprete e seu timbre que assumem esse papel; intimamente ligado, aliás, com aquilo que Tatit chamou anteriormente de "traço metonímico do intérprete". ${ }^{5}$

Longe de ser mera observação incidental, a natureza inevitavelmente somática da voz é recorrente na obra de Tatit. Na introdução de $O$ Cancionista (Tatit, 2002), vê-se essa noção apresentada com concisão lacônica: "Como extensão do corpo do cancionista, surge o timbre de voz. [...] A voz que canta prenuncia, para além de um certo corpo vivo, um corpo imortal. Um corpo imortalizado em sua extensão timbrística." (Tatit, 2002 , p. 15). Mais tarde, tal entendimento de timbre como corpo sonoro é reafirmado: "O corpo na voz compreende não apenas a materialidade sonora, o timbre, que pode ser por si só atraente, mas um modo de articulação já dependente da decisão do intérprete [...]." (Tatit, 2007, p. 146). Nessa mesma obra, essa concepção é desdobrada em detalhes ainda mais reveladores:

Todas essas observações nos fazem pensar que a exigência de fixação do plano da expressão, tão cara às atividades estéticas, tem o sentido de criar um prolongamento do corpo do sujeito, de modo que artista e obra sejam dimensões da mesma grandeza - e aqui retomamos sujeito e objeto como termos originários de uma unidade primordial - , fazendo do trabalho de execução uma duração do presente. (Tatit, 2007 , p. 260, grifos nossos)

Na passagem acima, vê-se bem esse "prolongamento do corpo do sujeito" reverberar a concepção de "corpo-feito-voz" de Parret (2002). ${ }^{6}$ Embora não haja referência explícita entre esses estudos, a feliz confluência de concepções permite reenquadrar sob nova perspectiva a problemática do timbre como remissão à fonte sonora. Por indiferente que possa parecer em princípio, tal conversão de termos permite superar as aferições quantitativas da acústica e da foniatria em favor de um entendimento qualitativo de timbre mais profícuo para tornar inteligível sua produção de significação. A primeira conquista que daí decorre é poder compreender o timbre como vestígio somático do sujeito da enunciação deixado no enunciado. Especificamente no universo cancional, a mediação entre essas duas instâncias pelo timbre é explicitada sem ambiguidades: "A função normalmente desempenhada pelo timbre, entretanto, é a de ponte de ligação entre as zonas de densidade tensiva dos enunciados melódicos e o sujeito da enunciação que, na canção popular, vem manifestado pelo cantor." (Tatit, 1997, p. 121).

\footnotetext{
${ }^{5}$ Cf. p. 15 acima

${ }^{6}$ Cf. p. 11 acima.
} 
Consolidando sua concepção de "metonímia do intérprete", Tatit dissipa qualquer dúvida quanto à pertinência enunciativa do timbre. A considerar todos os avanços já conquistados em matéria de enunciação, tal constatação oferece pistas sugestivas sobre o estatuto semiótico do timbre, cujas consequências serão desdobradas por completo em momento oportuno (cf. seção 1.2.2). Embora seus vestígios comecem a emergir pouco a pouco pelo presente levantamento bibliográfico, a voz permaneceu alojada em uma espécie de ponto cego conceitual da Semiótica da Canção, conforme manifestado pela seguinte passagem sintomática:

Se lembrarmos que para haver canção já temos que contar com um primeiro nível de figurativização, o da voz presente, a explicitação da presença do corpo - que, de resto, está pressuposto pela voz mas raramente referido - constitui um segundo nível de motivação que reforça a ilusão enunciativa. (Tatit, 2002 , p. 248, grifos nossos)

Segundo a tipologia proposta por Tatit, o processo de figurativização pode ser reconhecido, no domínio da letra, pelos mecanismos de dêixis e debreagem e, no domínio da melodia, pelas distensões rítmicas. Em contrapartida, ainda é pouco sistematizado o funcionamento desse "primeiro nível de figurativização", logicamente anterior aos demais processos de seu modelo. ${ }^{7}$

Nos escritos de Luiz Tatit, emerge intermitentemente a estreita relação entre timbre e fala, ambos ancorados como assinatura corporal do sujeito da enunciação: "A presença da fala é a introdução do timbre vocal como revelador de um estilo ou de um gesto personalista no interior da canção." (Tatit, 1997, p. 102, grifos nossos). Tudo se passa como se, por si só, a presença viva da voz instalasse toda a estrutura semântica e melódica da canção em um simulacro de locução em que um "eu" fala para um "tu" na acepção mais concreta desse verbo: "No limite, a simples presença da voz na canção popular já sugere à composição um impulso de figurativização (ou referencialização)." (Tatit, 1986 ,p. 7). Essa característica se entrelaça intimamente com certa tendência, própria da linguagem cancional, a sincretizar as instâncias do narrador e do interlocutor ${ }^{8}$, conforme se pode ver na seguinte passagem:

Um timbre de voz produzindo a melodia revela a entoação simultânea do interlocutor e do destinador-locutor (sincretizados), fazendo com que a locução principal e o simulacro

\footnotetext{
7 Nunca é demasiado ressaltar que os metatermos "tematização", "passionalização" e "figurativização" contraem acepção particular nos trabalhos da Semiótica da Canção (Tatit, 1997, 2002, 2007).

8 Sobre essa distinção conceitual, cf. Barros (2002, p. 72-75). Excepcionalmente em Tatit (1986), o metatermo "narrador" é substituído por "destinador-locutor".
} 
de locução tenham o mesmo tempo de existência: o tempo da canção. (Tatit, 1986 , p. 10).

Note-se que, já em sua primeira obra publicada, não passou despercebido a Tatit o frequente uso do timbre para revestir figurativamente diferentes atores do enunciado:

Visando maior figurativização, as interpretações conhecidas dessas canções ${ }^{9}$ trazem um timbre de voz específico para o interlocutor e outro diferente para o interlocutário. [...]. Já em outros exemplos, também dialógicos, esta discriminação sonora não aparece." (Tatit, 1986,p. 11).

O próprio autor nota, no entanto, que tal distinção tímbrica pode ser neutralizada. Não se pode ignorar que, desde seus primeiros momentos, a Semiótica da Canção já reconhecia certa quota de participação do timbre para criar o efeito de naturalidade e de eficácia da canção. Contudo, suas reflexões não se restringem aí. Quase vinte anos depois, o autor recupera indiretamente essa problemática em Todos entoam (Tatit, 2007) ao avaliar a importância histórica do estilo interpretativo de João Gilberto:

João [Gilberto] eliminou o timbre abaritonado, volumoso e impostado, que imprimia um tom solene (às vezes dramático) mesmo em composições singelas e adotou um registro e uma intensidade próximos da fala do dia-a-dia. [...] Além disso, de maneira involuntária, João Gilberto estava enviando uma mensagem inédita aos intérpretes e sobretudo aos compositores: todos os timbres e todas as potências de voz podem em princípio cantar. (Tatit, 2007 ,p. 147)

Mais do que uma assinatura vocal do intérprete, vê-se aí como a modulação timbrística cumpre o papel de conferir maior autenticidade e credibilidade à dicção cancional. Os inúmeros micro-ajustes vocais que compõem a fisionomia tímbrica do artista baiano visavam maior compatibilidade com os semantismos portados pela letra. Essa constatação desperta nosso interesse por levantar mais evidências da existência de relações de restrição mútua entre o binômio letra-melodia e o revestimento timbrístico que o manifesta. Se essa suspeita se confirmar, então um lance a mais terá sido dado para colocar em xeque a ideia de timbre como variante livre absolutamente isenta de coerções.

\footnotetext{
${ }^{9} \mathrm{O}$ texto se refere às canções "Eu dei" de Ary Barroso, "Não quero saber mais dela" de Sinhô e "Teresa da praia" de Tom Jobim e Billy Blanco.
} 


\subsubsection{Desdobramentos ulteriores}

Por dispersas que sejam, tais observações a respeito do timbre consolidaram certa concepção particular desse objeto que, de maneira mais ou menos implícita, acabou por ser herdada por outros estudos na área. Seus pontos de convergência poderiam passar despercebidos ao pesquisador menos empenhado em focalizar em filigrana os reflexos das ideias de Tatit. Uma delas é o pressuposto de que timbre e núcleo de identidade da canção (constituído pelo elo orgânico entre letra e melodia) não partilham o mesmo nível de análise.

Em sua proposta de homologação entre hierarquias melódicas e prosódicas, Carmo Jr. (2007) organiza em diferentes estratos os parâmetros musicais. Nesse modelo, os parâmetros de altura, duração e intensidade constituem o sistema denotativo de uma melodia tonal, ao passo que o sistema conotativo é composto por outros elementos, tais como a harmonia, a variação dinâmica e também o timbre (Carmo Jr., 2007, p. 127-147). Essa perspectiva se alinha ao entendimento de Tatit segundo o qual o timbre pode variar livremente e não está previsto pela composição. ${ }^{10}$ Por meio de provas de comutação e substituição, o autor argumenta pela pertinência do timbre ao domínio da conotação e assim declara:

Elaborar uma teoria da conotação da expressão musical equivale a reconstituir em redes os parâmetros que constituem as solidariedades observadas na substância da voz humana e dos instrumentos musicais. Existem razões para crermos que o andamento, a dinâmica e o timbre são algumas das categorias que poderiam constituir esse sistema de conotadores. (Carmo Jr., 2007,p. 146)

Tirando todas as consequências do extenso ferramental teórico oferecido pela glossemática de Hjelmslev (1969, 1975, 1991, 2006 [1943]), Carmo Jr. (2007) demonstra em termos semióticos por que o timbre pode ser variado sem prejudicar o núcleo estrutural de uma melodia. Entre outros fatores, o que dá poder descritivo a essa proposta é a compartimentação em diferentes níveis de análise. Em Carmo Jr. (2007), eles emprestam suas feições da oposição hjelmsleviana denotação vs. conotação. Embora assuma variações ligeiras nos demais trabalhos recenseados, é recorrente essa oposição entre dois momentos essencialmente distintos. O primeiro deles corresponde a uma etapa anterior e de natureza mais abstrata, ao passo que o segundo corresponde a uma etapa posterior de manifestação concreta.

Especificamente no caso da canção popular (e, por extensão, da música), esses dois momentos tendem a ser associados à composição e à interpretação, cujo entrelaçamento

\footnotetext{
${ }^{10}$ Cf. p. 15 acima.
} 
mútuo se vê problematizado quando Carmo Jr. (2007) assim declara: "De fato, toda composição musical nasce como uma interpretação real ou, então, como um simulacro de interpretação no imaginário do compositor" (2007, p. 144). ${ }^{11}$ Essa ideia de que a composição "antecipa" de alguma maneira elementos manifestados na interpretação reaparece também no pensamento de outros semioticistas. É o que se observa na proposta de Coelho (2007) para o arranjo na canção popular brasileira, nas investigações sobre a gestualidade vocal conduzidas por Machado (2012) e na reflexão crítica de Dietrich (2008) sobre modos de expandir coerentemente o escopo de objetos abrangidos pela Semiótica da Canção. Ainda que possa soar intuitiva para o senso comum do musicista ou do compositor, tal imbricação entre interpretação e composição traz consigo desdobramentos teóricos importantes.

Quem leva essa premissa até suas últimas consequências de maneira mais explícita é Coelho (2007). Lançando mão dos modos de existência semiótica formulados por Greimas, o autor propõe operacionalizar o percurso que vai da composição, passa pelo arranjo e desemboca na interpretação (2007, p. 5-121). Como pano de fundo, encontra-se a ideia de que o arranjo traz à manifestação estruturas semióticas elementares latentes em virtualidade.

Esse é, aliás, o mesmo princípio que sustenta sua tipologia de timbres empregados para compor um dado arranjo na canção popular (Coelho, 2007, p. 123-141). Pautando-se pelo modelo já estabelecido de Tatit (1997, 2004b), Coelho (2007) utiliza a estrutura do quadrado semiótico greimasiano para distinguir instrumentos "percussivos" e "melódicos". A hipótese colocada pelo autor é de que canções tematizantes priorizam instrumentos percussivos em seu arranjo. Simetricamente, canções passionalizantes tenderiam a receber arranjos com instrumentos melódicos (Coelho, 2007, p. 130-135).

Semelhante tentativa de descrever elementos pertinentes à interpretação buscando equivalências com os regimes de tematização, passionalização e figurativização foi verificada no trabalho de Machado (2012). Após apontar graves lacunas de bibliografia especializada no ensino de canto popular, a autora depura dos manuais existentes os principais elementos que modelam a gestualidade vocal dos intérpretes, distinguindo-os em três níveis: físico, técnico e interpretativo (Machado, 2012, p. 41-54). Após descrever e entabular o comportamento desses elementos em gravações diferentes de oito canções brasileiras, Machado (2012) categorizou o estilo dos intérpretes conforme perfis de "qualidade emotiva".

Fazendo coincidir a qualidade emotiva com os regimes de Tatit, Machado (2012,p. 164) deixa claro que, em sua concepção, uma descrição semiótica da gestualidade vocal precisa se pautar pelo modelo já vigente e explicar como os novos objetos de descrição (no

\footnotetext{
${ }^{11}$ Cf. Cap. 5, p. 155 .
} 
caso, o gesto interpretativo) trazem à manifestação os valores tensivos cifrados no núcleo de identidade da canção. Qualquer dúvida quanto a essa postura desaparece ao observar o oportuno uso do verbo "revelar" pela própria autora na seguinte passagem:

Ao transpormos para a voz os tipos de integração entre melodia e letra propostos por Tatit, pudemos concluir que cada tipo solicitava uma ação técnica particular do intérprete para que os valores inscritos na canção fossem revelados pela voz. (Machado, 2012 ,p. 158, grifos nossos)

Se centramos foco sobre tal minúcia da escolha vocabular da autora, é porque ela sintetiza de maneira lapidar a influência do pensamento de Tatit sobre os pesquisadores que o sucederam. Essa premissa básica de que o momento de interpretação vem trazer à manifestação valores semióticos latentes em um nível mais abstrato, comumente atribuído à composição, já foi colocada aliás explicitamente por Tatit (1997): "Questão intrigante: onde ficam armazenados os recursos da canção antes de sua explicitação instrumental e cênica?" (1997,p. 129, grifos nossos).

Por onde exatamente passa a linha divisória entre esses dois momentos, é uma questão ainda discutível, para fazer jus às objeções levantadas por Dietrich (2008). Esse autor faz observar que a análise da linha entoativa, conforme preconizada pelos estudos de Tatit, abstrai elementos que deveriam caminhar ombro a ombro com altura e duração na produção de efeitos de sentido no texto musical, como é o caso do timbre. No fundo, o que está em jogo é a virtualidade dos objetos de análise:

Quando o modelo analisa, por exemplo, a canção 'Garota de Ipanema', fazendo o recorte do seu perfil, ela passa a ser uma 'Garota de Ipanema' virtual, poderíamos até mesmo dizer 'genérica'. Ela não começa mais na nota sol3, dó5 ou lá4. Suas notas não têm mais o timbre cristalino de Gal Costa ou o grave cavernoso de Tom Jobim. Ela não é nem sussurrada como em João Gilberto, nem tem a impostação dada na versão de Pavarotti. (Dietrich, 2008,p. 246)

Com tal tomada de posição, Dietrich (2008) está não só propondo rever o caráter virtual da linha melódica, mas também reivindicando para o timbre igualdade de tratamento na análise. De fato, é em Dietrich (2008) que vemos o timbre ser colocado pela primeira vez diretamente sob holofotes semióticos. Esse autor mostra como o acréscimo progressivo de timbres no arranjo vai acompanhando o surgimento de papéis temáticos na letra das canções "Para todos" (Dietrich, 2008, p. 69-73), "O malandro" (Dietrich, 
2008 , p. 142-145) e "O meu amor" (Dietrich, 2008, p.146-148), todas elas compostas por Chico Buarque. ${ }^{12}$

Em momento posterior, o autor volta a enfatizar que a preponderância das alturas é antes uma questão de enfoque adotado pelo analista. Assim sendo, nada impediria em princípio uma transposição para o timbre da mesma abordagem conferida à melodia: "Podemos pensar então que existe um intervalo de altura entre duas notas, mas também existe um 'intervalo' de durações, intensidades e timbres" (Dietrich, 2008, p. 110). Essa instigante provocação nos atrai para um terreno ainda não-desbravado: como quantificar e, sobretudo, semiotizar tais intervalos de timbres? ${ }^{13}$

Antes de se ocupar de tais questionamentos, é preciso assinalar ainda outras confluências metodológicas dignas de nota. Em suas análises de peças instrumentais (Dietrich, 2008 , p. 137-148), vê-se o timbre não apenas demarcando as diferentes partes da macroforma musical, mas também recobrindo figurativamente papéis temáticos distintos. Sem qualquer referência explícita mútua, essa abordagem coincide, aliás, com aquela adotada por Pietroforte (2008, p. 128-129) ao analisar como a concentração e a expansão tímbrica se projeta semissimbolicamente sobre a alternância entre tema e variações em uma peça de jazz.

Em ambos os casos, a observação de que timbres se opõem e dialogam entre si não chega a ser exatamente inédita. Ao contrário, elas reverberam no fundo as observações de Tatit colocadas já em seu primeiro livro publicado sobre o revestimento figurativo de diferentes atores do enunciado. ${ }^{14}$ Pretendemos com isso explicitar certos elos à distância que, de outro modo, continuariam a passar despercebidos. Também Carmo Jr. (2007) tangencia a questão da figuratividade quando relaciona o timbre aos mecanismos de breagem na categoria de pessoa. A esse respeito, a passagem seguinte não poderia ser mais clara:

Por fim, o enunciador musical não pode dizer 'eu' ou 'tu', mas pode criar um efeito de presença enquanto timbre. Por isso falamos na 'voz' do piano, do violino, do oboé. Já vimos que reconhecemos a identidade de uma pessoa ou de um instrumento pela qualidade específica de seu timbre. (Carmo Jr., 2007,p. 175, grifos nossos)

Quando distingue "piano", "violino" e "oboé" como diferentes identidades reconhecíveis por trás do timbre, Carmo Jr. (2007) aborda, ainda que de maneira implícita, os diferentes recobrimentos figurativos que podem ser mobilizados na discursivização da

\footnotetext{
${ }^{12} \mathrm{Em}$ procedimento semelhante, merece destaque a análise comparativa de Jardim (2016) sobre os diferentes arranjos escritos para "Construção" de Chico Buarque.

${ }^{13}$ Essa questão será retomada posteriormente em p. 199.

${ }^{14}$ Cf. p. 19 acima.
} 
categoria de pessoa. Exatamente a mesma problemática é investigada por Dietrich (2008) a partir de sua perspectiva própria. Com o seguinte excerto diante de si, é difícil crer na fortuidade ou na irrelevância de tal confluência de ideias:

O reconhecimento do timbre vocal é um aspecto importante da comunicação humana, e é um fato da linguagem que não pode ser desprezado. A partir dos contrastes timbrísticos (e de registro e intensidade também) existentes entre vozes diferentes podemos reconhecer os falantes. Dentro de uma perspectiva semiótica, esse reconhecimento é, no fundo, a caracterização de um ator do discurso. Da mesma maneira que reconhecemos, em um texto escrito, o ator 'Elba Ramalho', também somos capazes de reconhecer esse mesmo ator a partir do seu timbre de voz característico. (Dietrich, 2008 , p. 145, grifos nossos)

Na passagem em questão, o autor resgata o timbre como remissão à fonte sonora, porém traduzindo-a em termos compatíveis com a reflexão semiótica. O que antes era referido de maneira apenas vaga como "fonte sonora" passa a assumir agora maior concretude e valor operacional na qualidade de ator do discurso. Modesto apenas em aparência, esse passo é decisivo para fazer avançar a semiotização do timbre.

É necessário ainda enfatizar o proeminente papel assumido pela operação de reconhecimento, mencionada quatro vezes apenas no excerto acima e já anunciada, aliás, na citação anterior de Carmo Jr. (2007). Sem precipitar o momento de destrinchar o estatuto semiótico desse "reconhecimento", queremos contudo enfatizar sua pregnância nas reflexões sobre o timbre. Mais do que mero mapeamento de fontes sonoras pré-dadas no mundo natural, o reconhecimento de timbres se faz em função de sua colocação em discurso - e nesse ponto ele não se distingue em nada dos outros parâmetros sonoros. É o que argumenta Dietrich (2008) no seguinte excerto:

[...] o reconhecimento de um instrumento é fruto de uma estratégia de construção do sentido. O enunciador tem o poder-fazer - e não o dever-fazer - de criar o efeito de sentido que leva ao reconhecimento de um instrumento. Pouco importa se esse instrumento tem existência real ou foi emulado em um sintetizador. Se percebermos determinado som como sendo o som de um violino, então a estratégia produziu seu efeito. (Dietrich, 2008,p. 126, grifos nossos)

Ao advogar pela superioridade heurística das já consagradas noções semióticas de "efeitos de sentido" e de "estratégia persuasiva", o autor desvencilha a análise do timbre de descrições anatômicas do aparelho fonatório e dos instrumentos musicais. Assim sendo, 
fica a abordagem semiótica imune às críticas que, por diversos motivos, confundem o timbre com a denominação que lhe é emprestada. Referir-se ao "timbre de flauta", por exemplo, não implica necessariamente que ele tenha sido emitido de fato por uma flauta de "carne-e-osso". Ao contrário, o que está em jogo é o reconhecimento de uma figura construída e posta em circulação pela atividade discursiva. Tal concepção figurativa de timbre vai se confirmando gradativamente no pensamento de Dietrich (2008) norteando-se sempre pela questão do reconhecimento:

O timbre, independentemente de suas características acústicas (e independentemente das suas condições de produção, como veremos), é sempre reconhecido como o som de algum instrumento. E um instrumento - uma vez reconhecido seu timbre - passa a ser não só um som, mas uma figura do mundo. (Dietrich, 2008, p. 139)

Mais à frente, a questão vem a ser reafirmada, porém não sem certos requintes de complexificação teórica:

No plano do conteúdo, os timbres são reconhecidos e identificados com sua fonte. Além disso, eles podem ser sérios ou descontraídos, frívolos ou austeros. Um timbre pode também ser dramático - ou simplesmente engraçado. (Dietrich, 2008 ,p. 141, grifos nossos)

Para além da sintomática recorrência da questão do reconhecimento da fonte sonora, sua alocação ao plano do conteúdo abre as comportas para uma torrente de questões teóricas e conceituais de consequências nada triviais. Antes de buscar meios de estancá-las ou canalizá-las adequadamente, não queremos encerrar essa seção sem destacar a coincidência da enumeração de adjetivos acima com a seguinte passagem testemunhada em Carmo Jr. (2007): "Existem timbres calorosos, afetuosos, ásperos etc., e todos esses efeitos sinestésicos nada mais são do que qualificadores de uma presença.” (2007,p. 175). Como se pode ver, os semioticistas levantaram uma miríade de problemas que não se deixarão resolver sem um sofisticado aparato conceitual.

\subsection{Interpretação e debate}

Mais do que apenas um exercício enciclopédico, a revisão crítica desses trabalhos nos mostra que, embora de maneira tangencial, o timbre esteve sempre presente no horizonte de reflexões semióticas. Resta, no entanto, uma investigação que aborde frontalmente essa problemática, procurando dar algum encaminhamento para os diversos 
pontos pendentes levantados até aqui. Para assumir essa empreitada, gostaríamos de pontuar algumas diretrizes gerais de natureza epistemológica e teórica, bem como algumas opções metodológicas.

\subsubsection{Diretrizes teóricas gerais}

Ocupando posição-chave no arquipélago conceitual da semiótica, é a enunciação que deverá nos abrir a porta de acesso para investigar o funcionamento semiótico do timbre. Conforme corrente na semiótica discursiva atualmente, observa-se que a enunciação comporta duas faces, uma interna e outra externa. Na primeira, a enunciação projeta marcas sobre o enunciado, modula-o e modela-o em suas estruturas semionarrativas, passionais, tensivas, temáticas e figurativas. Na segunda, a enunciação se relaciona a outras enunciações, emulando-as, polemizando-as e com elas construindo o grande tecido intertextual e interdiscursivo que constitui as práticas discursivas sociais.

Essa dupla natureza da enunciação nos habilita a conferir um tratamento verdadeiramente semiótico para o timbre. De um lado, ela permite examinar o comportamento do timbre na produção de sentidos em sua dimensão intratextual. De outro lado, ela explicita como a significação engendrada pelo timbre está intrinsecamente condicionada às diferentes esferas sócio-históricas e culturais em que ele é discursivizado. Por articular coerentemente essas duas perspectivas, a enunciação se oferece como uma via de escape às análises de caráter impressionista da crítica estética ou da musicologia, ao mesmo tempo em que permite emancipar o timbre do paradigma fisiologista.

Essa dissociação constitui outro grande princípio que norteará o presente estudo. Para semiotizar a percepção do timbre para além de sua configuração acústica, adotaremos a visada fenomenologizante que depreendemos, aliás, da própria revisão de literatura dos estudos da área. Ao privilegiar os efeitos de sentido produzidos pelo timbre em detrimento de suas condições empíricas de produção, Dietrich (2008,p. 139) ${ }^{15}$ resgata o espírito estruturalista concisamente sintetizado por Zilberberg (2011a) quando relembra que "de fato, uma das marcas da epistemologia estrutural é a indiferença pelas morfogêneses" (2011a , p. 68, tradução nossa ${ }^{\text {xiii }}$. Nessa mesma direção, vê-se corroborada também implicitamente a ideia de que a percepção não é uma captura passiva de estímulos sensoriais emanados de nosso mundo circundante. Ao contrário, ela já está impregnada pelas estruturas linguageiras e semióticas do sujeito.

Essa afinidade da abordagem semiótica com a concepção fenomenológica da percepção encontra evidências favoráveis nesta disciplina. Ao discutir sobre a percepção auditiva a partir da perspectiva da fenomenologia, François Bonnet (2012) declara que o

\footnotetext{
${ }^{15}$ Cf. p. 25 acima.
} 
som só passa a sê-lo quando é visado por um sujeito-ouvinte (2012, p. 63). Na mesma linha de raciocínio, o fenomenólogo Jean-François Lyotard (1954) enfatiza essa primazia da visada perceptiva sobre uma suposta realidade objetivada previamente: "Não se trata de saber se nós percebemos o real tal como ele é [...] pois justamente o real é aquilo que nós percebemos." (Lyotard, 1954, p. 58, tradução nossa ${ }^{\text {xiv }}$ ).

Alinhando-se a essa linha de raciocínio, a investigação semiótica supera o realismo ingênuo subjacente às mensurações acústicas para reconhecer que o timbre e os sentidos por ele engendrados podem ser compreendidos graças a sua impregnação sociocultural, e não apesar dela. Tal concepção encontra respaldo nas reflexões de Herman Parret (1988) sobre sinestesia e percepção musical:

Acrescento apenas que toda abordagem fenomenológica deveria aceitar o fato que a experiência - espacializante, entre outras - é determinada pela cultura e relativamente a ela e ao estado de sociedade nas quais percebemos os objetos musicais. A corporeidade, da qual nos falam Merleau-Ponty e Barthes, fonte de toda experiência sinestésica (aquela que nos faz perceber o espaço na duração musical), não é um dado da natureza, um a priori a partir do qual o mundo sócio-cultural e artístico se constrói. (Parret, 1988, p. 148, tradução nossa ${ }^{\mathrm{xv}}$ )

Reivindicamos a liberdade de apresentar essa passagem mais longa pois ela explicita como o mesmo gesto de desvinculação das condições de produção do timbre se aplica também ao seu caráter somático. Colocando Barthes e Merleau-Ponty em relação direta, Parret (1988) realça os contornos fenomenologizantes da corporeidade implicada no "grão da voz". Para além das coerções de ordem anatômica e fisiológica, o corpo projetado no timbre é, antes, um simulacro de corpo. É do contato desse corpo-feito-timbre com o corpo do sujeito da percepção que emerge sua significação, como mostra Parret (2002) ao dissertar sobre o caráter estésico da voz humana: "Por causa de seu espaço de desdobramento, a voz é um entrecorpo tocando o ouvido. A estesia da voz se transmite assim na sensualidade da escuta, na sensibilidade do ouvido, ela está no toque do ouvido." (2002, p. 28, tradução nossa ${ }^{\mathrm{xvi}}$ ).

Ao recuperar e complexificar a ideia de voz como extensão corporal do sujeito adotada por Tatit ${ }^{16}$, os argumentos colocados aqui revelam as insuficiências das descrições laboratoriais do timbre. Admitindo o corpo sensível do sujeito como sede da emergência de valores tensivos e fóricos (Fontanille \& Zilberberg, 2001), a presente investigação assumirá o compromisso de examinar o timbre em seu caráter inelutavelmente somático, fazendo deste a condição mesma de sua significação.

16 Cf. p. 16 acima. 
Outro ponto pendente apontado por nosso levantamento bibliográfico e que ainda merece ser tratado é a questão, levantada do confronto de posturas entre Dietrich (2008), Coelho (2007) e Machado (2012) ${ }^{17}$, do estatuto de virtualidade do timbre e, por extensão, dos modos de existência. Naquele momento, constatamos certo consenso implícito sobre o rendimento analítico proporcionado pela distinção entre um modo virtualizado e um modo realizado, cada qual abrigando seus elementos pertinentes (melodia, letra, arranjo, interpretação etc.). Mesmo as objeções levantadas por Dietrich (2008) quanto ao alocamento das variáveis não chegam a contradizer de fato essa divisão.

Embutida nessa bipartição, notamos também certa tendência entre os autores de buscar reencontrar nos novos objetos em análise a mesma tipologia cunhada por Tatit. É preciso, no entanto, se interrogar se essa conformidade ponto-a-ponto é necessária ou apenas uma opção metodológica. Sem violar a coerência teórica do modelo, há outras maneiras igualmente produtivas de vislumbrar essa integração entre os elementos da interpretação (dentre os quais, o timbre) e o núcleo virtual de identidade da canção. ${ }^{18}$

Para o presente estudo do timbre, esse nicho ocupado pelo núcleo de identidade da canção deverá ser expandido, de modo a abrigar também os enunciados puramente verbais da palavra falada e as estruturas puramente rítmico-melódicas da música instrumental. Essa expansão se faz necessária tendo em vista o caráter transversal do timbre, partilhado igualmente pela música, pela fala e pela canção. Em nome da homogeneidade da descrição, todos esses domínios precisam ser igualmente considerados em um quadro de investigação mais amplo.

Justifiquemos essa tomada de posição por uma analogia simples. Uma pesquisa de caráter verdadeiramente semiótico sobre a cor jamais poderia se circunscrever exclusivamente a uma semiótica da pintura, da fotografia ou do cinema. Da mesma maneira, um estudo sobre o timbre que almeje estatuto semiótico não poderá se limitar a contemplar apenas uma de suas manifestações, por maior que seja seu privilégio sociocultural.

É por transcender todas as esferas concretas em que marca presença que o timbre atinge o estatuto de objeto semiótico por excelência. No fundo, estamos remetendo aqui ao princípio epistemológico de que não há sentido pictural, musical, cinematográfico; antes, o sentido é humano (Greimas, 1976 [1966], p. 11 ss.). Marca de nascença da semiótica, esse poder de generalização não poderia ser barganhado impunemente em troca de ferramentas analíticas forjadas ad hoc para atender a apenas um dos muitos usos particulares do timbre.

\footnotetext{
17 Cf. p. 20 acima.

${ }^{18}$ Cf. Cap. 5, p. 155 ss.
} 


\subsubsection{Balanço intermediário e plano de trabalho}

Ao contrário, é graças à abstração teórica proporcionada pela semiótica que poderemos esclarecer os equívocos causados pelas distintas acepções de timbre, sendo considerado ora como identificador de uma fonte única, ora como nuance expressiva de um mesmo instrumento ou voz. No levantamento bibliográfico acima apresentado, apuramos essa duplicidade do timbre em dois momentos. Enquadrando-se na primeira acepção está a ideia de timbre como figura do mundo, conforme afirmado expressamente por Dietrich (2008) e presente de maneira residual em Carmo Jr. (2007) e Coelho (2007). A segunda acepção se deixa reconhecer com maior nitidez quando Dietrich (2008) e Carmo Jr. (2007) mencionam os adjetivos sinestésicos frequentemente usados para caracterizar o timbre.

Visando resolver essa dualidade, o capítulo 2 levantará as ferramentas semióticas que permitem dar encaminhamento a essa discussão para além do senso comum. Para tal, retomaremos e extrairemos todas as consequências da hipótese avançada por Dietrich (2008) segundo a qual o timbre é uma figura do mundo. ${ }^{19}$ Afinal de contas, o que significa exatamente dizer que o timbre figurativiza entidades do mundo natural? Em busca de respostas satisfatórias a tais questionamentos, empreenderemos um estudo vertical sobre o conceito de figuratividade em semiótica. ${ }^{20}$ Resgatando os meandros da constituição desse conceito em Greimas (1984) e Jean-Marie Floch (1985, 1995), procuraremos argumentar como a distinção entre diferentes graus de densidade figurativa pode dar conta da duplicidade do timbre referida acima.

Esse dispositivo conceitual começará a ganhar contornos mais concretos no capítulo 3, no qual centraremos foco sobre a morfologia do timbre. Partindo da tipologia de instrumentos musicais proposta por Coelho (2007), procuraremos extrair dela seus componentes temporalizantes para conferir-lhes novo arranjo aos moldes do quadrado semiótico de segunda geração preconizado por Greimas \& Courtés (2012 [1979],p. 403). Além de maior simplicidade e adequação aos objetos empíricos, tal reformulação visa também traduzir em termos semióticos a temporalidade implicada nas diferentes fases estacionárias que constituem o envelope sonoro, tido usualmente como correlato acústico do timbre.

Assim sendo, os momentos de ataque, sustentação e extinção sonora são convertidos em uma rede relacional articulando aspectualidade e andamento. Um dos interesses da descrição nesses termos é explicar, ao menos em parte, por que tendemos a perceber certos timbres como "doces" e outros como "ásperos" ou "cortantes". Em contrapartida, outros aspectos relevantes do timbre ainda não são satisfatoriamente contemplados.

Por exemplo, essa categorização não consegue por si só explicar a inequivalência

\footnotetext{
${ }^{19}$ Cf. p. 25.

${ }^{20}$ Cf. Cap. 2.
} 
entre timbres de mesmo perfil temporal, verificada tanto na música popular quanto na música erudita. Devido ao seu alto grau de abstração, as categorias postas em jogo aí acabam por agrupar timbres percebidos empiricamente como distintos e mesmo incompatíveis entre si. Necessária porém não suficiente, a descrição do perfil temporal do timbre requer ainda complementos que expliquem tais incompatibilidades.

Para atender a essa demanda, dedicaremos o capítulo 4 às relações intertimbrísticas. No fundo, o que estamos tentando compreender é por que determinadas combinações de timbres são mais frequentes ao passo que outras jamais ocorrem. O que a semiótica teria a dizer sobre essa aparente predisposição dos timbres a se mesclar ou a se repelir entre si? Indo ainda além, seria possível também se perguntar se esse grau de compatibilidade entre timbres seria, no fundo, aquilo que Dietrich (2008) vislumbrou como um "intervalo de timbres". ${ }^{21}$

Com o intuito de operacionalizar essas intuições, esboçaremos uma aplicação ao timbre das reflexões de Greimas sobre as relações contratuais e polêmicas entre actantes. Os traços dessa proposta deverão ainda ser refinados por meio das operações de triagem e mistura conforme teorizadas por Zilberberg (2004). Conferindo maior granularidade a essa lógica de participação e exclusão subjacente ao timbre, o esquematismo tensivo possibilita descrever os mecanismos semióticos por trás das prescrições e restrições de misturas tímbricas que podem ser encontradas nos manuais de orquestração.

Dado o caráter suficientemente abstrato de sua conceptualização, cremos que a sintaxe extensiva poderá descrever com êxito as relações de (in)compatibilidade de timbres entre si, mas não contempla a compatibilização do timbre com seu substrato linguístico e/ou melódico, problema já levantado em momento anterior. ${ }^{22}$ Postulando a existência de diferentes graus de conformidade também nesse domínio, procuraremos argumentar no capítulo 5 por que o revestimento timbrístico de um enunciado verbal, musical ou cancional não pode ser sempre livremente permutado, ao contrário do que preconiza o senso comum sobre o assunto. ${ }^{23}$ Entre o timbre e seu subtrato, existe um nexo que, embora passe despercebido na maioria das situações mais corriqueiras, pode desencadear efeitos de sentido peculiares sob determinadas circunstâncias.

Para conduzir essa discussão, enquadraremos essa compatibilidade como uma projeção da instância da enunciação sobre o enunciado. Recuperando as já estabelecidas noções de debreagem e embreagem, discutiremos como o timbre pode ser entendido como desencadeador de uma "embreagem sensível", conceito este apresentado pelas últimas propostas da semioticista Verónica Estay-Stange (2011,p. 20). Trabalharemos com a hipótese de que o timbre encarna o lado sensível do aparelho formal da enunciação,

\footnotetext{
21 Cf. p. 23

${ }^{22}$ Cf. p. 28

${ }^{23}$ Cf. p. 15
} 
funcionando na prática como um correlato não-verbal do dêitico "eu".

Condição indispensável de sucesso dessa operação enunciativa é a cristalização do timbre em um protótipo, cujo reconhecimento acarreta a restituição desse "eu" projetado no enunciado. Para além do mapeamento neutro de seus traços acústicos constitutivos, reconhecer um timbre significa, antes de tudo, cotejá-lo com um modelo previamente estocado na memória do sujeito. Trata-se, portanto, de uma questão de fazer veridictório, tema já familiar à semiótica greimasiana (Greimas, 2014 [1983], p. 115-145). É o ato de julgamento executado pelo sujeito que decidirá o sucesso ou o fracasso do reconhecimento do timbre e, consequentemente, de sua projeção enunciativa. Todo esse mecanismo enunciativo posto em funcionamento pelo timbre será flagrado em exemplos concretos extraídos da fala coloquial, da canção e da música.

Nesse momento, vale a pena ressaltar que essa tipificação do timbre não é pautada por um modelo fornecido a priori no mundo natural, mas sim regida pela circulação em discurso por intermédio da práxis enunciativa. Ao fim e ao cabo, todos os atributos observados no timbre devem passar pela sanção coletiva da comunidade de sentido (Greimas, 1981, p. 40-44) na qual o timbre circula. É a cristalização na memória coletiva que consolida ou descaracteriza a singularidade do timbre. É ela também que regula as boas misturas tímbricas na orquestração e na instrumentação de um arranjo. No limite, é igualmente a práxis que arbitra sobre o quantum de aceleração e desaceleração atribuído ao perfil temporal dos timbres.

Ao longo da presente empreitada, os diversos conceitos semióticos deverão ser empregados mantendo sempre em vista a enunciação como pano de fundo. Graças a ela, a abordagem semiótica conquista seu lugar de direito em um terreno disputado por diversos programas de pesquisa que, a despeito de sua robustez científica, não logram capturar o timbre em sua face mais enigmática: o sentido.

\section{Citações traduzidas no original}

ii "The various objective scores presented in this chapter show nothing about timbre. It is fully recognized that this fourth factor in singing is by far the most important characteristic of voice, but it is also the most complicated factor". (Seashore, 1967, p. 283)

iii “On peut identifier le timbre caractéristique d'un chanteur à travers une restitution très déformée et donc malgré la distorsion du spectre des fréquences. En effet, le timbre est un phénomène complexe qui ne se réduit pas au spectre acoustique et dépend également de l'évolution dynamique des sons (attaque ou décroissance), c'est-à-dire des variations dans le temps de leurs intensités. Chaque voix conserve une couleur qui lui est particulière même lorsque, par filtrage, les intensités relatives des partiels affectent sa qualité." (Ducard, 2002, p. 41-42)

iv "On a beau voir une corde vibrer, le rapport n'est pas très évident entre ce fuseau, que la stroboscopie analyse pour l'œil, et l'unité sonore si convaincante qui le signale à notre oreille. D'un gong, d'une 
trompette, on ne voit rien". (Schaeffer, 2002 ,p. 161).

v"Les grands structuralistes - Jakobson, Hjelmslev, Troubetzkoy - sont solidaires quant à cette mise entre parenthèses de la voix, et ils n'hésitent pas à prendre l'axiomatique saussurienne en témoin." (Parret, 2002, p. 52)

vi"Ce que l'on perçoit et sent quand une voix nous atteint, n'est pas une voix "libérée" du corps qui la profère, mais c'est le corps même fait voix. Et pourtant la voix est l'indécidable du corps. Elle naît de lui mais elle l'oublie, l'efface." (Parret, 2010, sem paginação)

vii "Sobald eine Stimme nicht mehr auf die Anwesendheit einer konkreten Person bezogen werden kann, auf keinen Ort und keinen Körper, [...], wirkt sie mächtiger und bedrohlicher als jedes überraschende Geräusch. Davon zeugen viele Berichte aus der Geschichte der Religionen und den Archiven moderner Psychiatrie: Götter und Dämonen manifestieren sich häufiger in köperlosen Stimmen als in Visionen." (Macho, 2006 ,p. 131)

viii “[... a land of disembodiment where cancellation of the visual and the bodily is successfully imagined." (Grover-Friedlander, [s/d] ,p. 205-206)

ix "In its biological function, then, the auditory system is both the danger sense as well as a portent of the future ('what is happening as an indication of what is likely to happen'). Hearing warns us of changes behind us or at a distance, that is to say, in places we cannot see, and in this way prompts us to action" (Kassler, [s/d], p. 327)

x"Confident of their auditory acuity, listeners feel themselves directly and aurally linked to a source in the acoustic world. So strong is the source orientation of environmental listening, that listeners project the fundamental premise of their auditory logic onto the data it is meant to interpret and subjective auditory sensation onto a world of sources until sound equals source. We say - I hear a cricket; not - I hear a sound that may indicate the presence of a cricket." (Fales, 2002, p. 63)

xi“"Mais l'aspect qualitatif représente encore une source de difficultés pour une transcription complète. La seule indication de l'instrument paraît insuffisante lorsque le timbre est, dans le cas de la valiha, traité comme élément fondamental de variations et de stylisation du répertoire. Une solution possible consisterait à caractériser la « palette sonore » du musicien après que l'ethnomusicologue l'ait préalablement déterminée, en prenant en compte certains points déterminants dans la production du son. Le choix des matériaux de fabrication (bambou, acier, tôle?), des dispositifs particuliers de jeu (élastique, doublés ou triplés de cordes, micro-contact?) doivent être spécifiés." (Razafindrakoto, 1999,p. 16)

xii "No amount of notational intricacy can account for the extreme and relatively unpredictable complexity and flux in musical timbre [...]" (Reed, 2005,p. 21)

xiii "En effet, une des marques de l'épistémologie structurale est l'indifférence pour les morphogénèses." (Zilberberg, 2011a,p. 68)

xiv"Il ne s'agit pas de savoir si nous percevons le réel tel qu'il est [...] puisque précisément le réel est ce que nous percevons." (Lyotard, 1954,p. 58)

xv"J'ajoute seulement que toute approche phénoménologique devrait accepter le fait que l'expérience spatialisante, entre autres - est déterminée par, et relative à la culture, à l'état de société dans laquelles nous percevons des objets musicaux. La corporéité, dont nous parlent Merleau-Ponty et Barthes, source de toute expérience synesthésique (celle qui nous fait percevoir de l'espace dans la durée musicale), n'est pas une donnée de la nature, un a priori duquel le monde socio-culturel et artistique se construit." (Parret, 1988 ,p. 148)

xvi “À cause de son espace de déploiement, la voix est un inter-corps touchant l'oreille. L'aisthèsis de la voix se transmet ainsi dans la sensualité de l'écoute, dans la sensitivité de l'oreille, elle est dans le toucher de l'oreille." (Parret, 2002 ,p. 28) 


\section{Capítulo 2}

\section{Timbre E CATEGORIZAÇÃO}




\section{Capítulo 2}

\section{Timbre e categorização}

\subsection{Nomear e qualificar: categorizações ambivalen- tes}

Conforme revelado em levantamento bibliográfico ${ }^{1}$, descrições linguísticas de timbre se valem principalmente de duas estratégias. A primeira consiste em nomear a fonte sonora, atribuível a uma entidade do mundo natural. A segunda estratégia é qualificar o objeto sonoro, valendo-se para tal de adjetivações metafóricas. Essa duplicidade descritiva é capturada com concisão lapidar pela seguinte passagem:

Frequentemente explicamos nossas percepções simplesmente nomeando a fonte sonora como etiqueta para o timbre, ou por uma combinação de metáfora, onomatopeia, mímica vocal e gestualidade. Poderíamos usar metáforas multimodais como 'brilhante' ou 'áspero' para descrever essas impressões sensoriais, com variados graus de concordância entre os ouvintes a respeito do significado específico desses termos. (Heidemann, 2016, p. 3, tradução nossa ${ }^{\text {xvii }}$ )

Tal como colocada, a constatação parece não ir além do senso comum sobre o tema. Ao invés de desdenhar tais fatos como triviais, o semioticista de bom senso deveria buscar tirar proveito deles, mantendo certa atitude de suspeição positiva. Desse modo, cumpre agora perseguir as pistas fornecidas por esse material para desdobrar todas as suas consequências desse duplo caráter do timbre.

\footnotetext{
${ }^{1}$ Cf. Cap. 1.
} 


\subsubsection{Categorização por nomeação}

A primeira estratégia de categorização mencionada pelo excerto acima remete à já tradicional definição de timbre como identificação da fonte sonora. Dar-se por satisfeito com uma definição reducionista de fonte é uma atitude tão infértil quanto ignorar por completo a problemática, proclamando-a impertinente. Embora possa ser mais cômodo desviar o olhar da questão da fonte sonora, sua recorrência é indício de uma importante propriedade do timbre que ainda aguarda uma resolução semiótica suficientemente satisfatória.

Da formulação tal como apresentada, merece destaque a ideia de "nomeação". Para identificar e designar a fonte por trás do timbre, recorre-se a substantivos concretos, sejam eles próprios (antropônimos) ou comuns. Tal observação sobre a forma gramatical da descrição não é gratuita, mas sim um indício da organização dos timbres em um sistema global. Referir-se à identidade sonora do timbre usando substantivos significa associá-lo a entidades e/ou classes de entidades do mundo e, portanto, pertinentes à ordem do inteligível. Para reconhecer, por trás de um evento sonoro, um timbre de clarinete, violão, violino, Chico Buarque, Frank Sinatra, etc., é preciso que essas entidades estejam já previamente discretizadas dentro de uma dada comunidade de sentido. Da mesma maneira, os substantivos concretos das línguas naturais denotam classes e indivíduos delimitáveis.

De fato, essa característica de identificação tem inegável impacto empírico em nossa experiência cotidiana. Uma evidência cabal disso é a identificação de falantes pelo procedimento de "perícia de voz" no campo da fonética forense. ${ }^{2}$ Tal pregnância do timbre com a identidade está também por trás de projetos comerciais especializados em síntese de voz, não só para restituição da identidade vocal de pacientes afetados por distúrbios de linguagem, mas também para a homogeneização do branding sonoro de clientes corporativos por meio da criação de vozes exclusivas ${ }^{3}$. A despeito de sua banalidade anedótica, casos como esses são sintomas inequívocos da relevância dessa função de remissão à fonte sonora.

Se insistimos nesse ponto, é porque reconhecemos nele uma causa reincidente do desconforto frente às dificuldades de descrição do timbre. Se entendida de maneira demasiado reducionista, essa visada nominalizante forçaria a conclusão de que existiriam tantos timbres quanto fossem as entidades do mundo identificáveis como fonte sonora. Sem dificuldades, entende-se por que o não-fechamento e a variabilidade dos inventários

\footnotetext{
${ }^{2}$ Segundo o Instituto Brasileiro de Peritos, "[o]s termos "identificação de falantes" e "perícia de voz" se referem à tarefa de verificar se determinada voz/fala armazenadas em gravações de áudio e/ou vídeo são oriundas do aparelho fonador de um indivíduo." Disponível em: < https://ibpbrasil.com.br/fonetica/ identificacao-humana-pela-voz/43/>. Acesso em 21/08/2019

${ }^{3}$ Cf. ACapela Voice Banking. Disponível em: < https://www.acapela-group.com/voices/voice-banki ng $>$. Acesso em 21/08/2019.
} 
assim construídos motivam os pesquisadores a superar a nomeação da fonte.

\subsubsection{Categorização por qualificação}

Além da remissão à fonte sonora, a descrição do timbre também recorre ao uso metafórico de adjetivos qualificativos que remetem a outras ordens sensoriais. ${ }^{4}$ A passagem citada acima menciona os termos "brilhante" e "áspero", mas também é frequente falar de timbres opacos, macios, cortantes, doces, entre outros (Parret, 2002, p. 41-47). A descrição por meio de adjetivos metafóricos não é uma "deficiência" por falta de metalinguagem descritiva, como insinua o pouco caso dispensado por certos autores a esse modo de categorização . Ao contrário, essa questão tem um robusto respaldo fenomenológico:

Da mesma maneira, no ruído de um automóvel ouço a dureza e a desigualdade dos paralelepípedos, e com razão fala-se em um ruído 'frouxo', 'embaçado' ou 'seco'. Se se pode duvidar de que a audição nos dê verdadeiras 'coisas', pelo menos é certo que ela nos oferece, para além dos sons no espaço, algo que 'rumoreja' e, através disso, ela se comunica com os outros sentidos. (Merleau-Ponty, 1999, p. 309)

O resgate do pensamento de Merleau-Ponty (1999) nesse momento deve também reafirmar o caráter inelutavelmente somático e corporalizante de tais descrições sinestésicas. Por sua ancoragem ao corpo próprio do sujeito, tais adjetivações remetem ao domínio do sensível e, portanto, do contínuo. Designações como "timbre seco", "timbre áspero" ou "timbre metálico" apontam para categorias amplas, apenas vagamente delimitadas e de fronteiras fluídas. É parte dessa estratégia descritiva certo grau de indeterminação.

Nesse aspecto, não é ocasional que os qualificativos sinestésicos se manifestem como adjetivos, uma vez que essa categoria gramatical denota uma qualidade ou classe de entidades. Desde longa data, a linguística já reconhece a indeterminação como uma das peculiaridades semânticas da classe dos adjetivos. A exemplo das diferentes tonalidades cromáticas denotadas pelo adjetivo "branco", Gomes \& Mendes (2018) ilustram didaticamente esse ponto e sintetizam de forma lapidar: "Propriedades, como a brancura, não existem por si só, mas são encontradas nos indivíduos e substâncias que as apresentam." (2018 , p. 154). Essa mesma amplitude de espectro extensional se verifica também no uso de adjetivos metafóricos para descrever e categorizar o timbre.

\footnotetext{
${ }^{4}$ Cf. Cap. 1.2 .2 , p. 25.
} 


\subsubsection{Qualidades e entidades: uma articulação possível?}

Diante desse cenário, pode-se de boa fé questionar: haveria algum ponto de articulação entre esses dois modos de categorizar o timbre? Caso positivo, como ele se constroi? Esse caráter ambíguo do timbre impõe à semiótica o desafio de propor uma abordagem descritiva capaz de contemplar ambas as facetas de maneira unificada e coerente. De um lado, fala-se de timbre nomeando sua fonte sonora. São empregados substantivos que designam entidades discretas específicas, inteligíveis e, portanto, da ordem do conceptual. De outro lado, o timbre é descrito de maneira apenas inespecífica por suas qualidades sensíveis. São empregados adjetivos sinestésicos calcados na ordem do sensível e do perceptual. Sistematizemos essas características subjacentes às duas principais visadas categorizantes sobre o timbre (cf. Tabela 2.1):

\begin{tabular}{ll}
\hline Nomear & Qualificar \\
Fonte sonora & Qualidade sonora \\
Substantivos & Adjetivos \\
Entidades & Qualidades \\
Discreto & Gradual \\
Conceptual & Perceptual \\
Inteligível & Sensível \\
\hline Violino, flauta, guitarra, oca- & som metálico, fosco, brilhante, \\
rina, trombone, Caetano Veloso, & áspero, escuro. rouco, sibilante \\
Ella Fitzgerald etc. & etc. \\
\hline
\end{tabular}

Tabela 2.1: Visadas categorizantes sobre o timbre e suas propriedades. Fonte: elaboração própria.

Embora deixe intocada a questão do não-fechamento do inventário de timbres, essas constatações criam condições para estabelecer os parâmetros de sua descrição. Desde já é preciso enfatizar incisivamente que não é objetivo do presente trabalho inventariar e categorizar o vocabulário descritivo do timbre. Embora tal mapeamento tenha seu interesse e tenha sido já ensaiado por outros pesquisadores (Parret, 2005), uma tal abordagem resvalaria nos mesmos impasses que levaram Greimas a abandonar a lexicografia (cf. Fiorin, 2017a). Ao invés de elaborar apenas mais uma nova tipologia, é mais proveitoso buscar uma abordagem alternativa que dê conta desse caráter ambivalente do timbre. Para resolver essa tensão, o conceito semiótico de figuratividade oferece uma via promissora.

\subsection{Uma ferramenta de análise: a figuratividade}

A escolha pela figuratividade não é uma decisão de livre escolha. Ao contrário, ela visa explorar as potencialidades e os limites da hipótese aventada em Dietrich (2008) 
segundo a qual o timbre funciona como uma figura do mundo. O que isso significa, afinal de contas? Quais são as decorrências (teórico-metodológicas e aplicativas) de tal assunção? A busca por essas respostas exige forçosamente uma revisão das principais características da figuratividade conforme estabelecida na semiótica. ${ }^{5}$

Para início de discussão, pode-se recuperar as explanações do Dicionário de semiótica I (Greimas \& Courtés, 2012 [1979], p. 209-213), que definem a figurativização como investimento semântico dos actantes instalados no nível narrativo. Dentro do quadro teórico geral do percurso gerativo de sentido, sujeito e objeto nada mais são do que posições sintáticas puramente relacionais. O estatuto de sujeito só pode ser avaliado em função de sua relação juntiva com o objeto. Até esse ponto, nada permite identificá-los a qualquer entidade do mundo natural.

É com a operação de figurativização que esses actantes passam a ganhar concretude. Greimas \& Courtés (2012 [1979],p. 211) apresentam como exemplo um enunciado elementar de estado, em que um sujeito está em conjunção com um objeto-valor investido da modalidade do poder. Na etapa seguinte do percurso gerativo de sentido, esse objeto pode vir a ser figurativizado como um automóvel, mas também como uma espada, uma bicicleta, um tapete voador etc. Essa figura inicial encaminha quais figuras serão selecionadas no desdobramento do texto, de modo a instaurar uma grade de leitura coerente. É o que estabelece Greimas quando assim afirma: "Dir-se-á, então, que a figurativização instala percursos figurativos e, se estes forem coextensivos às dimensões do discurso, farão aparecer isotopias figurativas." (Greimas \& Courtés, 2012 [1979] , p. 211, verbete 'figurativização', §3). ${ }^{6}$

Pode-se resumir dizendo que a figuratividade assume dois papeis principais: (i) recriar, dentro do texto, entidades identificáveis a figuras do mundo; (ii) conferir sensorialidade e concretude a elementos narrativos e discursivos do texto (cf. Barros, 2004). Essa identificação de figuras do mundo não se dá de maneira ingênua como mero reflexo da realidade. Não se trata de simplesmente transplantar, dentro dos textosenunciados, uma coleção de objetos já pré-prontos no assim chamado mundo do senso comum. Ao contrário, trata-se de uma atividade de re-construção por meio da linguagem e, assim sendo, pode assumir diferentes graus de adesão ao mundo assumido como "real". Esse caráter gradual prevê, então, que a figuratividade não é só uma reunião acidental de figuras identificáveis a objetos do mundo. Ao invés disso, esse é apenas o polo mais concreto de um largo espectro contínuo, em cujo extremo oposto encontram-se as figuras rarefeitas.

Para melhor esclarecer essas propriedades do conceito, bem como sua aplicabili-

\footnotetext{
${ }^{5}$ Para uma revisão exaustiva, cf. Farias (2002) e Prado \& Santos (2017).

${ }^{6}$ Cf. também Cap. 4, p. 135 ss.
} 
dade ao timbre, faz-se necessária agora uma explanação mais pormenorizada e organizada em três momentos. Em primeiro lugar, discute-se a figuratividade como mecanismo de conversão de figuras do mundo para figuras do discurso. Em segundo lugar, passa-se a debater a figuratividade como um continuum abrangendo do icônico ao abstrato. Por fim, esses aspectos da figuratividade serão sistematizados para demonstrar como ela dá conta do caráter dúplice do timbre.

\subsubsection{Figuratividade e percepção: da figura do mundo para a figura do discurso}

O primeiro aspecto do conceito de figuratividade a ser discutido aqui é aquele mais explicitamente associável à definição corrente de timbre como identificação da fonte sonora. Conforme prenunciado anteriormente, o repositório de figuras tende, em princípio, a coincidir com aqueles objetos que povoam o mundo do senso comum. Essa primeira impressão decorre da relação estreita entre figuratividade e percepção.

A figuratividade é o lugar teórico em que se pode flagrar o momento de conversão das qualidades sensíveis, apreensíveis pela percepção em si mesma, em traços semânticos constitutivos das línguas naturais. Em outros termos, trata-se da interface de conversão de figuras do mundo, alimentadas pelo ato perceptivo, em figuras do discurso, já autônomas e emancipadas de seu substrato material originário (cf. Farias, 2002). Mais do que apenas um capricho intelectual descartável, tal distinção entre figura do mundo e figura do discurso é essencial para garantir a coerência epistemológica da descrição. Não se trata aqui de apenas atribuir etiquetas linguísticas a entidades naturais, mas sim de reconstruí-las na e pela atividade discursiva.

Farias (2002, p. 52-60) aponta que essa conversão é mediada pelo corpo-próprio do sujeito da percepção; corpo esse concebido como uma unidade proprioceptiva semiotizada, e não mais em sua constituição psico-biológica. Assim sendo, pode-se bem dizer que a figuratividade está apoiada no vértice de articulação entre plano da expressão da macrossemiótica do mundo natural e plano do conteúdo da semiótica da língua natural. A esse respeito, é útil retomar as palavras da própria autora: "É ele, o corpo, que permite a mediação entre o mundo natural e a língua natural ou mais do que isso: o corpo permite a passagem das figuras do mundo para as figuras do discurso." (Farias, 2002, p. 70).

O excerto resume de maneira sintética o entendimento consensual na literatura semiótica sobre a interrelação entre figuratividade e percepção, bem como seu papel de conversão entre mundo natural e língua natural. Em Bertrand (2003), essa conversão é referida pelo termo "transcodificação": "[...] : o conceito de figuratividade, indicando a transcodificação das figuras da expressão do mundo natural em figuras do conteúdo 
das línguas naturais, foi introduzido, substituindo as propriedades exteroceptivas; [...]" (Bertrand, 2003, p. 259). Nesse excerto, o autor bem aponta como a noção de figuratividade foi paulatinamente substituindo aquela de exteroceptividade, tomada de empréstimo à fenomenologia e mais marcadamente presente nos primeiros momentos do desenvolvimento da disciplina (cf. Greimas, 1976 [1966]).

O verbete "exteroceptividade" do Dicionário de Semiótica I (Greimas \& Courtés, 2012 [1979]) distingue as propriedades exteroceptivas das interoceptivas, apontando que as primeiras correspondem sempre a elementos do assim chamado mundo exterior, ou seja, aquele apreendido pela percepção. Na sequência, o autor continua debatendo certos problemas terminológicos e assim declara: "Parece-nos que figurativo, em se falando das categorias e dos inventários sêmicos desse plano, pode substituir exteroceptivo e semiológico." (Greimas \& Courtés, 2012 [1979], p. 199, verbete 'exteroceptivo'). No excerto em questão, "figurativo" é proposto como substituto mais conveniente para esses traços que remetem ambiguamente ao plano da expressão do mundo natural e do plano do conteúdo das línguas naturais, referidos até então como exteroceptivos. Vê-se, assim, como a figuratividade e seu termo correlato "figurativo" podem bem se aplicar, em semiótica, para fazer referência às categorias sêmicas alimentadas pelas qualidades sensíveis capturadas pela percepção. ${ }^{7}$ Essa linha de leitura se confirma com uma breve consulta ao verbete "figurativo" nessa mesma obra:

Ao contrário do termo figura (que é polissêmico) do qual deriva, o qualificativo figurativo é empregado somente com relação a um conteúdo dado (de uma língua natural, por exemplo), quando este tem um correspondente no nível da expressão da semiótica natural (ou do mundo natural). (Greimas \& Courtés, 2012 [1979] ,p. 212, verbete 'figurativo', $\S 1)$

Indo na mesma direção, as definições apresentadas no verbete "mundo natural" corroboram esse entendimento. Ao menos ao se pautar pela linha de raciocínio ali desenvolvida, pode-se assumir como plausível essa relação direta entre figuratividade e qualidades sensíveis:

Por outro lado, e sobretudo, o mundo natural é uma linguagem figurativa, cujas figuras - que encontramos no plano do conteúdo das línguas naturais - são feitas das 'qualidades sensíveis' do mundo e agem diretamente - sem mediação linguística - sobre o homem. (Greimas \& Courtés, 2012 [1979] , p. 325, verbete 'mundo natural')

\footnotetext{
${ }^{7}$ Cf. Greimas \& Courtés (2012 [1979] ,p. 449, verbete 'semiótica'): "os femas do mundo natural correspondem, no plano figurativo, aos semas das línguas naturais; [...]".
} 
Do cruzamento de tais definições, depreende-se como a noção de figuratividade permite dar conta do universo sensorial do mundo que nos rodeia. Ele é concebido como uma macrossemiótica cujo plano de expressão se constitui da torrente de impressões sensoriais que nos atinge via percepção. Alocada na interface entre o plano da expressão do mundo natural e o plano do conteúdo da língua natural, a figuratividade converte as qualidades sensíveis capturadas pela percepção em primitivos semânticos nas línguas naturais. O respaldo a esse entendimento é oferecido pela conceptualização de Courtés (1991):

Qualificaremos de figurativo todo significado, todo conteúdo de uma língua natural e, de maneira mais abrangente, de qualquer sistema de representação (visual, por exemplo), que tenha um correspondente no plano do significante (ou da expressão) do mundo natural, da realidade perceptível. Logo, será considerado figurativo, num determinado universo de discurso (verbal ou não-verbal), tudo que puder ser diretamente referido a um dos cinco sentidos tradicionais [...]; em suma, tudo que se liga à percepção do mundo exterior. (Courtés, 1991,p. 163)

A passagem destaca que, embora concebido visando as linguagens verbais, o conceito de figurativo se aplica também a todo tipo de linguagem de manifestação. Isso permite vislumbrar uma categorização do timbre em função de seu grau de investimento figurativo, conforme seu poder maior ou menor de iconização de entidades do mundo. Antes de passar aos detalhes dessa proposta, convém-nos contudo insistir ainda mais um instante sobre esse caráter mestiço da figuratividade, a meio caminho entre o que é da ordem do percebido e o que é da ordem do concebido.

Para tal, é útil se debruçar sobre a seguinte esquematização visual elaborada em Estay-Stange \& Bertrand (2014a). Os autores apontam que o quadro se pretende menos uma formalização estrita do percurso gerativo do que uma disposição panorâmica de grandes problemáticas a serem trabalhadas pela semiótica discursiva. Optando por passar ao largo de tudo aquilo que não concerne diretamente ao nosso problema de pesquisa, fica então o leitor instado a centrar sua atenção no quadrante direito superior intitulado "iconicidade"8 (cf. Figura 2.1).

Fazendo um balanço avaliativo dos principais desafios de pesquisa mapeados por tal representação visual, os autores colocam uma observação crucial para sua correta leitura e que acrescenta elementos decisivos para entender as interrelações entre figuratividade e percepção. Nas palavras dos autores:

\footnotetext{
${ }^{8}$ A relação entre figuratividade e iconicidade será esmiuçada a seguir (cf. Seção 2.2.2)
} 


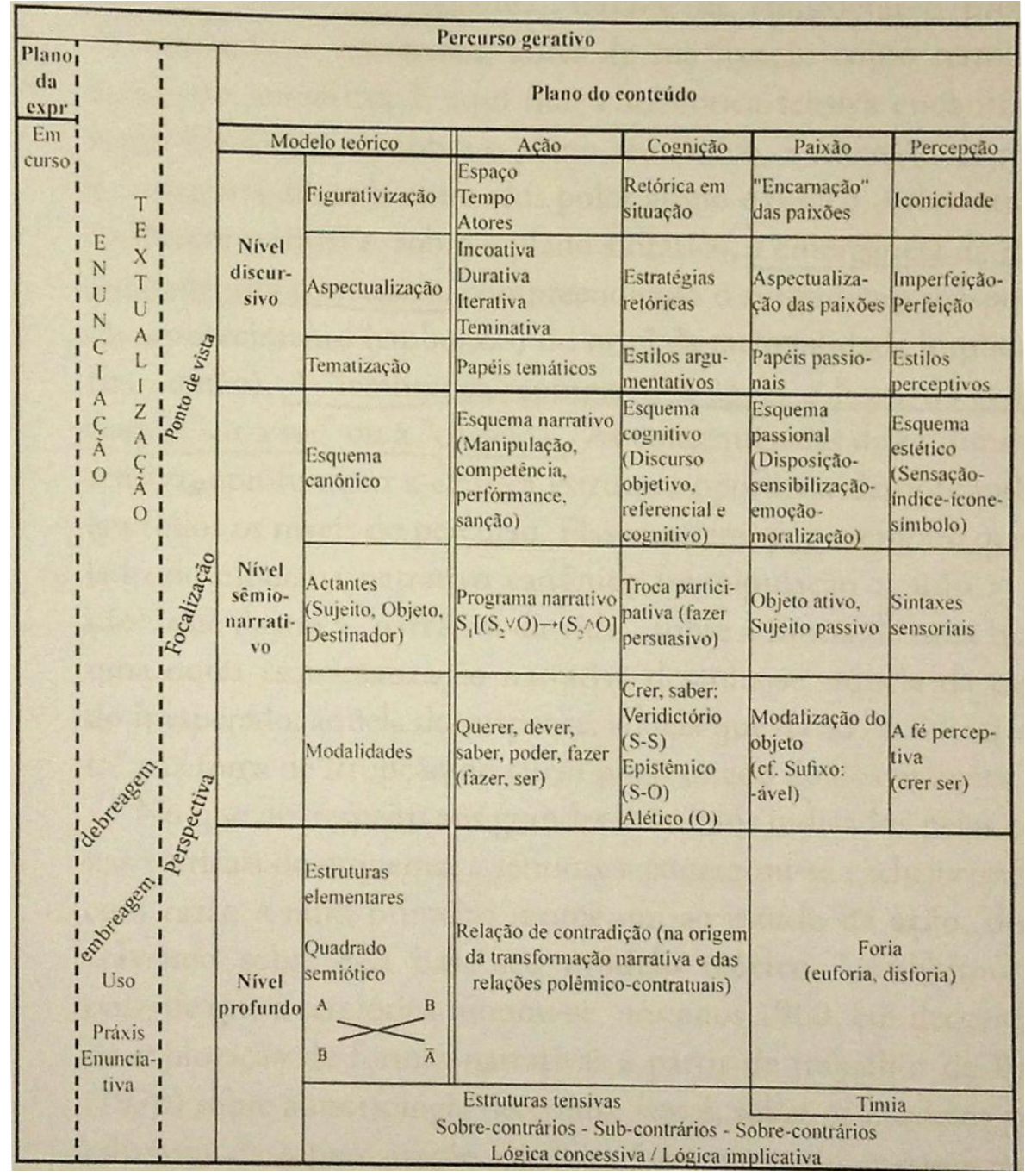

Figura 2.1: Percurso gerativo da significação. Fonte: Estay-Stange \& Bertrand (2014a,p. 15)

Pode-se, contudo, formular a hipótese de que a coluna da percepção une precisamente aquela do plano de expressão, como se o quadro se fechasse para formar uma espécie de cilindro. De fato, como as pesquisas atuais mostram ao apelarem para a fenomenologia, a configuração do plano da expressão está estreitamente correlacionada à estrutura mesma da percepção que a apreende. (Estay-Stange \& Bertrand, 2014a, p. 20, grifos no original)

Tendo essa informação em mãos, pode-se enxergar com mais clareza o nicho ocupado pela figuratividade (mais especificamente em sua forma mais condensada, a saber, a iconicidade) no edifício teórico da semiótica. No eixo vertical, a figuratividade se localiza no mais alto grau de concretude do percurso gerativo. Assim sendo, ela é um dos componentes mais imediatamente palpáveis ao sujeito-enunciatário. Ao mesmo tempo, no eixo horizontal, a figuratividade se encontra também exatamente nas margens 
onde plano de expressão e plano de conteúdo se encontram, segundo a representação em cilindro proposta pelos autores. Assim sendo, não é fortuita a dificuldade classificatória experimentada pelo analista diante dos termos empregados nas descrições do timbre. Eles são extraídos do repositório de figuras disponíveis que, como se pode atestar, emanam do alagadiço terreno do sentido irrigado pelas qualidades sensíveis provindas da percepção. Nessa visada perceptiva, apreende-se tanto as figuras em seu estágio mais bem acabado quanto os primitivos figurais que lhe subjazem, como bem notam as reflexões de Keane (1991):

A percepção aparece, nesse sentido, como o lugar estratégico privilegiado para uma investigação semiótica, pois ela designa assim as principais direções, a um só tempo, da abstração e da concretização da pesquisa. Uma vez admitido isso, pode-se em seguida proceder por indução, partindo das figuras iconizadas encontradas nos textos para desvesti-las em busca do figurativo mais profundo que estaria subjacente aos ícones. (Keane, 1991, p. 15, grifos nossos, tradução $\left.\operatorname{nossa}^{\text {xviii }}\right)$

Nesse momento, deve-se evitar desde já o risco de resvalar em uma homologação imediata com os dados do mundo natural. Mais do que mero decalque de qualidades sensíveis, a construção do repositório figurativo é necessariamente intermediada por formas linguageiras, bem como os códigos culturais que lhe são correlatos. Sobre o papel imprescindível de tais grades de leitura, as reflexões de Bastide (1983) sobre o tema dissipam todas as dúvidas:

É necessário observar que essa definição do figurativo pressupõe a existência de uma segmentação do plano da expressão do mundo natural em elementos reconhecíveis para que uma correspondência possa ser estabelecida. Ora, a noção de 'elementos reconhecíveis' depende da cultura do leitor [...] A ideia de 'elemento' supõe a existência de uma grade de interpretação do mundo [...]. (Bastide, 1983, p. 16, tradução $\operatorname{nossa}^{\mathrm{xix}}$ )

O excerto em questão deixa claro que a depreensão dessas figuras só pode resultar inteligível graças à mediação de estruturas de linguagem. Para jogar com os termos da própria autora, os "elementos" só se tornam "reconhecíveis" dentro de um crivo de leitura particular. Mais adiante, a explanação volta a insistir na questão do reconhecimento como elemento-chave dessa conversão entre qualidades sensíveis em figuras: " [...] : a figura é um elemento do mundo que não é reconhecível senão em um discurso particular" (Bastide, 
1983 , p. 17, tradução nossa ${ }^{\mathrm{xx}}$ ). Reafirmar a dependência da figura ao discurso significa, no fundo, reconhecer seu estatuto de construto linguístico, e não mais de pré-dado natural. Esse entendimento é também corroborado em Bertrand (2003), que por sua vez reitera a questão do reconhecimento:

A análise de textos visuais mostrou que um crivo de leitura do mundo natural era necessário para transformar os objetos visíveis em figuras iconizáveis, assim permitindo sua identificação e seu reconhecimento numa representação figurativa. (Bertrand, 2003,p. 248, grifos nossos)

Se insistimos em chamar atenção para os termos "identificação" e "reconhecimento", é porque eles nos fornecem pistas reveladoras para entender o comportamento semiótico do timbre. ${ }^{9}$ Além disso, tal escolha de palavras evidencia também a necessária participação do sujeito nesses processos. Para ser reconhecida como tal, a figura depende da validação do enunciatário. O reconhecimento comum de um "mundo natural" por trás da figuratividade é possibilitado pelo / crer-verdadeiro/ que enleia enunciador e enunciatário em um pacto fiduciário (Bertrand, 2003,p. 235 ss.). Discorrendo sobre a abordagem semiótica da imagem, Floch (1985b) resgata em primeira mão as definições de Greimas (1983b) sobre contrato de veridicção para mostrar como o efeito de simulacro do real criado pela figuratividade depende desse acordo prévio entre sujeitos:

Dir-se-á que a 'parecença' pressupõe a instalação (logicamente anterior) duma espécie de conivência entre o enunciador, o produtor, e o enunciatário, o receptor. [...] Uma tal comunicação supõe um saber do enunciador sobre o saber do enunciatário, um saber sobre o que este último considera ser a 'realidade' e sobre o que ele julga ser fiel a esta realidade. (Floch, 1985b, p. 77). ${ }^{10}$

Essas reflexões corroboram as proposições de Greimas (1984) sobre semiótica visual publicadas um ano antes. Em "Semiótica figurativa e semiótica plástica", esse semioticista confere ainda mais amplitude para esse entendimento, atribuindo-lhe o poder de conferir inteligibilidade à percepção:

É essa grade [figurativa] de leitura que torna o mundo significante para nós, permitindo identificar as figuras como

\footnotetext{
${ }^{9}$ No que diz respeito especificamente aos aspectos enunciativos dessa distinção, cf. Cap. 5 adiante.

${ }^{10}$ Em momento anterior, o autor aborda essa questão em termos de "contrato de iconidade" (cf. Floch, 1978).
} 
objetos, classificá-los, ligá-los entre si, interpretar os movimentos como processos, atribuíveis ou não a sujeitos, etc.: de natureza semântica - [...] - ela serve de 'código' de reconhecimento que torna o mundo inteligível e manejável. (Greimas, 1984 ,p. 9, tradução nossa ${ }^{\text {xxi }}$ )

Tecidas inicialmente para os textos visuais, tanto as reflexões de Greimas (1984) quanto as de Floch (1985b) se aplicam igualmente a todo tipo de texto, à revelia de sua linguagem de manifestação. Ao contemplar uma fotografia, organizamos intuitivamente seus formantes visuais (linhas, formas, volumes, cores etc.) para reconhecer aí objetos do mundo. Da mesma maneira, quando a leitura de um romance nos convence de sua verossimilhança e seu efeito de "realismo", é graças a certa conformidade às grades de leitura culturalmente impostas e partilhadas pelos sujeitos. A situação não é diferente com textos sonoros, sejam eles musicais, cancionais ou verbais. Se identificamos um instrumento musical ou uma pessoa específica por trás de um timbre, é porque essa figura do mundo já foi semioticamente construída por nós em algum momento anterior e, assim sendo, integra nosso entendimento do que deve ser assumido como "real" ou "realista".

O mesmo se aplica também ao cenário oposto, isto é, quando o objeto sonoro não nos remete a nenhuma figura claramente identificável, como acontece com sons sintetizados. Se não somos capazes de reconstituir nenhuma entidade do mundo, é porque esse objeto sonoro escapa a essa grade figurativa de leitura. Para um leitor mais apressado, essa possibilidade poderia parecer invalidar nossa proposta de entender o timbre como figuratividade. Se há cenários em que o timbre não remete a nenhum objeto do mundo, poder-se-ia então colocar em cheque a semiotização da fonte sonora como figura. Essa objeção é refutada por outros aspectos do conceito de figuratividade, sobre os quais convém agora lançar luz.

\subsubsection{Do figurativo ao plástico}

A pista para solucionar esse impasse se encontra no mesmo estudo de Greimas (1984) quando assim afirma: "A iconização e a abstração não são senão graus e níveis variáveis da figuratividade" (Greimas, 1984, p. 11, grifos nossos, tradução nossa xxii). Já em sua versão inicial, a proposta do semioticista lituano para a semiótica visual assumia que o reconhecimento de objetos do mundo era consequência de um ápice de investimento figurativo. Desde então, tem-se denominado "iconização" esse estado de máxima concentração sêmica que cria a ilusão referencial. Essa propriedade é assim sumarizada em Barros (2004): "O efeito de realidade é obtido pelo uso da figurativização em grau extremo, ou iconização, pois leva ao reconhecimento de figuras do mundo, que o destinatário do texto interpreta como 'reais'.' (2004, p. 14) 
Segundo o entendimento corrente na área, essa ilusão é um construto linguageiro que cria o efeito de sentido de real, emulando-o no discurso tal como concebido como o mundo do senso comum. O emprego de termos como "ilusão", "simulacro", "efeito" não é fortuito. Ao contrário, eles reiteram o caráter discursivo da impressão de "realismo" produzida pela iconicidade ${ }^{11}$, que não deve ser entendida como simples réplica biunívoca do mundo natural (Greimas \& Courtés, 2012 [1979], p. 251). Na sequência, os mesmos autores prosseguem a explanação refinando o entendimento de iconização em semiótica e sumarizam essa distinção conceitual da seguinte forma:

Esse conjunto de considerações nos leva a introduzir o termo iconização para designar, no interior do percurso gerativo dos textos, a última etapa da figurativização do discurso em que distinguimos duas fases: a figuração propriamente dita, que responde pela conversão dos temas em figuras, e a iconização que, tomando as figuras já constituídas, as dota de investimentos particularizantes, suscetíveis de produzir a ilusão referencial. (Greimas \& Courtés, 2012 [1979], p. 251, grifos nossos)

Esse modo de conceptualizar a iconização é rentável para um estudo sobre o timbre porque permite distinguir diferentes graus de investimento semântico e figurativo. Nessa perspectiva, o reconhecimento de objetos do mundo é apenas um dos diferentes efeitos possíveis da figuratividade. Debatendo o emprego desse expediente no romance realista francês, Bertrand (2003) sintetiza essa distinção de maneira lapidar: "Essa iconicidade, portanto, nada mais é do que uma forma dentre outras possíveis de explorar componentes figurativos da expressão linguística" (Bertrand, 2003, p. 208).

Tal reflexão sobre a iconicidade registra detalhes conceituais indispensáveis para entender semioticamente o timbre. Na passagem em questão, merece atenção a noção de "investimentos particularizantes", relacionada à produção de ilusão referencial. Da maneira como formulada, a explanação permite traçar uma correlação direta entre iconização, grau de particularização e ilusão referencial.

Assim sendo, o efeito de sentido de realismo é tanto mais intenso quanto maior for o grau de "investimento particularizante". Esse efeito de particularização é consequência de uma alta iconização, entendida esta como etapa última do acabamento figurativo do discurso. Tal relação entre ilusão referencial e grau de especificação encontra respaldo direto na arquitetura conceitual da semiótica:

\footnotetext{
${ }^{11}$ Ao longo desse trabalho, o conceito de "iconicidade" e seus correlatos ("ícone", "iconização" etc.) são empregados conforme sua acepção na semiótica greimasiana clássica e em determinados desdobramentos posteriores, e não tem relação com conceituações homônimas no paradigma teórico de C. S. Peirce. Embora dignos de nota, os desenvolvimentos propostos por Bordron (2018) não serão por ora contemplados devido à sua singularidade no cenário atual dos estudos semióticos.
} 
Sendo a figurativização caracterizada pela especificação e a particularização do discurso abstrato, [...], a introdução de antropônimos, topônimos e de cronônimos [...] que se podem inventariar como indo dos genéricos (o 'rei', a 'floresta', o 'inverno') aos específicos (nomes próprios, índices espaçotemporais, datações, etc.), tal introdução, repetimos, confere ao texto, segundo se supõe, o grau desejável de reprodução do real. (Greimas \& Courtés, 2012 [1979],p. 212 , verbete 'figuratividade', grifos nossos)

Desse excerto, gostaríamos de destacar enfaticamente como a figuratividade se atrela a um processo de particularização articulável em uma escala gradual do genérico ao específico. No primeiro polo dessa escala, o investimento figurativo rarefeito engendra ancoragens de tempo, espaço e pessoa generalizantes. No polo oposto, a figuratividade concentrada torna essas coordenadas particularizadas e específicas. A explanação dos autores permite identificar essa rarefação figurativa em gêneros discursivos como a fábula e o conto maravilhoso, mas também a parábola e o apólogo. Neles, é precisamente esse caráter inespecífico que lhe confere a presumível universalidade de sua interpretação arquetípica. Indo na direção contrária, a concentração figurativa máxima confere especificidade e, assim procedendo, emula um efeito de "reprodução do real", para retomar as palavras dos próprios autores. Não é outra a premissa que sustenta o trabalho de Bertrand (1982, 1985) sobre o papel da iconicidade e da "roupagem descritiva" na construção de efeitos de referencialização no realismo francês. ${ }^{12}$ A respeito dessa escala gradual da figuratividade, esse autor assim sintetiza:

A diferença semântica precisa entre os polos icônico e abstrato é interpretada pela semântica estrutural em termos de densidade sêmica. [...] A iconicidade ocorrerá se os traços que o formante reúne forem suficientes para "permitir sua interpretação como representante de um objeto do mundo natural'." (Bertrand, 2003,p. 210, grifos nossos)

No trecho em questão, vê-se essa escala gradual do abstrato ao concreto ser referida pela expressão "densidade sêmica". Desdobrando o potencial desses termos até as últimas consequências, podemos então considerar como icônico o mais figurativamente denso e o abstrato como o menos denso, ou mesmo "rarefeito". Na mesma direção das reflexões de Bertrand (1982, 2003), o termo "densidade" é atestado também em Zilberberg

\footnotetext{
${ }^{12}$ Acerca desse mesmo universo estético, Barthes (1968) observa que a profusão de "detalhes inúteis" descritivos, descartáveis para uma análise estritamente em funções narrativas, visa recriar um efeito de real: "Os resíduos irredutíveis da análise funcional têm isso de comum, de denotar o que se chama comumente de o « real concreto »". (1968, p. 87, tradução nossa ${ }^{\text {xxiii }}$ )
} 
(2011b , p. 193) referindo-se ao alto grau de detalhamento das anedotas e da assim chamada "pequena história" documentada por certa vertente do jornalismo.

A reincidência da noção de densidade não é apenas uma comodidade terminológica fortuita. Ao contrário, ela está presente no Dicionário de Semiótica I (Greimas \& Courtés, 2012 [1979]), considerado como a grande súmula dos conceitos mais canônicos da teoria. Nele, a densidade sêmica é definida como um critério semântico que "permite medir o grau de abstração de um conceito" (2012 [1979], p. 123, verbete "densidade sêmica"). Corrobora esse entendimento a definição, constante da mesma obra, de que "um termo qualquer [...] é abstrato quando sua densidade sêmica é fraca" (2012 [1979], p. 17, verbete "abstrato"). Mais tarde, essa noção será resgatada por Greimas (1983a) em suas proposições sobre a semiótica plástica. Trabalhando naquele momento com a distinção conceitual entre icônico e abstrato, o autor assim pontua:

Uma vez que o desenvolvimento desse discurso [referencial] leva em conta um número cada vez mais elevado de figuras 'gestálticas', sua densidade sêmica aumenta, permitindo falar então de figuras icônicas e de iconização do figurativo. (Greimas, 1983a, p. 49, grifos nossos, tradução nossa xxiv)

Alguns anos depois, esse instrumento conceitual continuará a ser esmerado. Ainda que permutando o termo "icônico" por "figurativo", permanece como premissa de base o entendimento de figuratividade como uma escala gradual de densidade sêmica:

Isso significa, ao mesmo tempo, que o figurativo e o abstrato não se opõem no plano categorial, mas como dois polos numa escala, que admitem posições intermediárias: o figurativo não é outra coisa senão o menos abstrato, do mesmo modo que o abstrato pode ser considerado como o menos figurativo (o que pode ser interpretado, de acordo com A. J. Greimas, em termos de 'densidade sêmica' maior ou menor). Tratase, pois, somente de uma relação (entre um mais e um menos), variável de um contexto a outro: [...] (Courtés, 1986 [1979],p. 76, grifos nossos)

Vale a pena enfatizar aqui a expressa recusa de uma concepção categórica em benefício de uma concepção gradualizada, escalar e reversível entre um "mais" e um "menos". Essa postura oferece o respaldo necessário e suficiente para a nossa proposta de sistematizar o amplo inventário de timbres conforme seu poder de iconização, esta entendida, por sua vez, em termos de densidade sêmica/figurativa.

Tal como apresentado acima em Courtés (1986 [1979]), figurativo (i.e. icônico) e abstrato se espelham mutuamente de maneira simétrica e inversa. Nesse sentido, a 
formulação se mostra inesperadamente semelhante à ambivalência e à reversibilidade das dimensões e das subdimensões do esquematismo tensivo (cf. Zilberberg 2004, p. 125-126). Tal compatibilidade sugere, convenientemente, certo potencial de rendimento da aplicação desse aparato analítico na organização do universo figurativo dos timbres.

Chegando a esse ponto, convém agora sintetizar os principais achados até o momento para, em seguida, proceder à sua sistematização. Em primeiro lugar, constatouse que a figuratividade resulta da conversão de qualidades sensíveis do mundo natural pela percepção e pelo corpo próprio do sujeito. Observou-se também que as figuras assim obtidas não têm todas o mesmo estatuto. Ao invés disso, elas assumem diferentes graus de especificação, traduzíveis em termos de densidade sêmica. Homologando essas duas categorias, pode-se então alocar, em uma extremidade da escala, o específico e o denso e, na outra extremidade, o genérico e o rarefeito. De posse desses ingredientes conceituais elementares, torna-se possível agora avançar uma proposta de organização que, delineando as condições de controle necessárias, confere sistematicidade ao tratamento semiótico do timbre.

\subsection{Um dispositivo gradual: sistematizando os graus de figuratividade do timbre}

Usualmente, os casos de reconhecimento de timbres mais debatidos são aqueles em que é identificado um sujeito único, particular e exclusivo, como parece insinuar a definição corriqueira de "impressão digital sonora". No entanto, os dispositivos teóricos acima levantados permitem enxergar que, embora seja o mais proeminente, esse é apenas um dos cenários possíveis, que em nada difere do reconhecimento de uma classe timbrística fechada contendo mais ou menos representantes. Entre a identificação de um sujeito exclusivo ("Chico Buarque", "Frank Sinatra" etc.) e um exemplar de uma família timbrística ("violão", "bandolim", "viola caipira" etc.), a diferença é apenas de grau de especificidade. Essa homologia entre especificação e densidade figurativa pode ser representada graficamente lançando mão de um gradiente tensivo, conforme mostrado na Figura 2.2.

$\begin{array}{cccc}\underset{\text { denso }}{\mathrm{S}} & \mathrm{S} 2 & \mathrm{~S} 3 & \mathrm{~S} 4 \\ \text { específico } & & & \begin{array}{l}\text { rarefeito } \\ \text { genérico }\end{array}\end{array}$

Figura 2.2: Homologação entre densidade figurativa e grau de especificação. Fonte: Elaboração própria com base em Zilberberg (2011b). 
A representação visual linear ao invés da tabular frequentemente empregada em Zilberberg $(2011 b$, 2012) coloca em evidência o caráter contínuo, gradual e biorientado dessa escala. Para validar essa homologação, cumpre agora pormenorizar cada passo da linha de raciocínio que leva a esse resultado. Para tal, faz-se necessário explorar em profundidade os mecanismos conceituais do esquematismo tensivo (cf. Fontanille \& Zilberberg, 2001; Fontanille, 2007; Zilberberg, 2004, 2006a, 2011a,b, 2012).

\subsubsection{Densidade figurativa e inteligibilidade}

A organização aqui proposta assume que o grau de densidade figurativa investido no timbre pode ser concebido como uma medida intensiva, contínua e suscetível a operações de aumentos e diminuições. Por sua vez, essas últimas traduzem semioticamente a progressiva construção perceptiva do repositório timbrístico estocado na memória do sujeito. Em conformidade com a grade teórica da abordagem tensiva, essa dimensão da intensidade é mapeável por meio de uma matriz articulada pela oposição de sobrecontrários e subcontrários, em que os primeiros representam limites e os segundos, graus, conforme sistematizado em Zilberberg (2012,p. 51 ss.; 2011b,p. 78 ss.) (cf. Tabela 2.2). ${ }^{13}$

\begin{tabular}{llll}
\hline S1 & S2 & S3 & S4 \\
supremo & forte & fraco & nulo \\
sobrecontrário & subcontrário & subcontrário & sobrecontrário \\
\hline
\end{tabular}

Tabela 2.2: Matriz da dimensão da intensidade. Fonte: adaptado de Zilberberg (2012, p. 72, tradução nossa) e Zilberberg $(2011 b$,p. 79-84)

Renomeando os termos dessa matriz em função da escala gradual de densidade figurativa, obteríamos então a seguinte disposição (cf. Tabela 2.3):

\begin{tabular}{llll}
\hline S1 & S2 & S3 & S4 \\
icônico & denso & rarefeito & abstrato \\
sobrecontrário & subcontrário & subcontrário & sobrecontrário \\
\hline
\end{tabular}

Tabela 2.3: Matriz da dimensão da intensidade aplicada à densidade figurativa do timbre. Fonte: elaboração própria adaptada a partir de Zilberberg (2012,p. 72 ss.) e Zilberberg (2011b,p. 79-84)

\footnotetext{
${ }^{13}$ No que diz respeito à orientação dessa escala, Zilberberg (2012, 2011a) e Zilberberg (2011b) se contradizem frontalmente. Em Zilberberg (2012, p. 70 ss.) e Zilberberg (2011a,p. 55 ss.), o termo S1 é designado como "sobrecontrário átono" e o termo S4 como "sobrecontrário tônico". Por sua vez, em Zilberberg (2011b,p. 81 ss.) essa atribuição é invertida: S1 é qualificado como valência paroxística e S4 como valência nula. Diante dessa flagrante discrepância, adotamos deliberadamente a formulação apresentada em Zilberberg (2011b). Essa escolha se baseia em nada além de mera conveniência, uma vez que a opção alternativa deixaria intacta a validade dos argumentos, bastando apenas permutar a disposição dos termos no gradiente tensivo.
} 
Tirando um decalque da terminologia extraída de Greimas (1984) e Floch (1985), nomeamos provisoriamente como "icônico" o limite superlativo de densificação figurativa do timbre. Sem ignorar o caráter apenas provisório de tais etiquetagens, propomos denominar "abstrato" o estágio de mínima densificação figurativa. Entre eles, interpolam-se os termos subcontrários que, devido à atonia própria dos graus intermediários da escala, se prestam menos bem às lexicalizações com as quais o analista se vê obrigado a lidar.

A densidade figurativa contrai relação direta com nossa capacidade de reconhecer as entidades por ele iconizadas. Timbres figurativamente rarefeitos se mostram menos compreensíveis para nós. Defrontamo-nos com um evento sonoro ao qual não conseguimos associar nenhum objeto do mundo conhecido. Não somos capazes de atribuir ao timbre em questão uma fonte sonora claramente identificável. Recaímos, então, na descrição por meio de metáforas sinestésicas, as quais nada nos dizem sobre a natureza exata dessa fonte. Um exemplo concreto disso é toda sorte de ruídos indistintos cuja identidade não conseguimos precisar: um guincho agudo à noite na mata pode ser um pássaro inofensivo ou um animal ameaçador e essa indefinição enche de apreensão um caminhante solitário. A despeito de sua discrepância aparente, esse é o mesmo caso de um ouvinte que se aventura na apreciação musical de composições completamente distantes de seu próprio universo cultural. Para além do exercício hedonista de fruição estética, a inespecificação timbrística também cumpre inegável papel pragmático quando vem proteger o anonimato de testemunhas em casos policiais ou quando ameaça vítimas de chantagens telefônicas (cf. Schilling \& Marsters, 2015), como ocorre no assim chamado trote do falso sequestro. ${ }^{14}$

Em contrapartida, timbres figurativamente densos nos permitem identificar uma entidade do mundo inequivocamente reconhecível. É tipicamente o caso do reconhecimento de nosso intérprete favorito ao rádio, mas também de um interlocutor em um mero "alô" ao telefone. É o que acontece também em anúncios publicitários radiofônicos, dublagens e na instalação de narradores em textos audiovisuais por meio da técnica conhecida como voice over. ${ }^{15}$

Nos termos da semiótica greimasiana, tal competência de identificação e reconhecimento é um fazer-interpretativo, um /crer-verdadeiro/ que se processa no universo cognitivo do sujeito (cf. Greimas, 2014 [1983]) e, como tal, inegavelmente atinente ao âmbito do inteligível. Assumindo como plausível essa equiparação, pode-se sintetizar essa correlação da seguinte maneira: quanto maior a densidade figurativa do timbre, mais inteligível ele se apresenta. Raciocinando na direção inversa, essa equivalência pode ser formulada ao avesso: quanto menor a densidade figurativa do timbre, menos compreensível ele será ao sujeito. Essa correlação pode ser visualizada mais claramente com auxílio de

\footnotetext{
${ }^{14}$ Cf. Cap. 5, p. 164 ss.

${ }^{15}$ Cf. Cap. 5, p. 160 ss.
} 
uma curva conversa (cf. Figura 2.3).

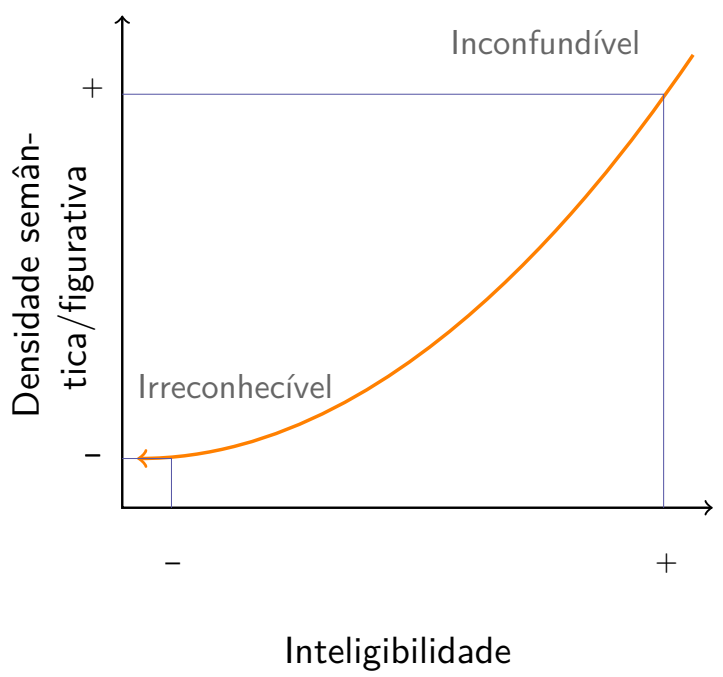

Figura 2.3: Relação conversa entre densidade figurativa e grau de inteligibilidade do timbre. Fonte: elaboração própria.

Arriscando uma lexicalização provisória, propomos denominar "inconfundível" o ápice desse percurso ascendente converso. Esse extremo especulativo corresponderia a um hipotético timbre que iconizasse uma entidade específica a tal ponto de não poder ser confundida com nenhuma outra. Na extremidade oposta dessa curva, a atenuação nessas duas dimensões corresponderia a um evento sonoro que não pudesse ser associado a absolutamente nenhuma figura inequivocamente nomeável, ou mesmo "irreconhecível". Entre esses dois pontos extremos, desdobra-se toda a miríade de graus intermediários de especificidade e inteligibilidade que nos rodeia na vida cotidiana. Nesse aspecto, tal percurso de adensamento e rarefação figurativa se assemelha à "caminhada do 'touro' à "tauridade"' apontada por Silva (1995, p. 42) na série de litogravuras de Picasso intitulada As metamorfoses de um touro (cf. Figura 2.4).

\subsubsection{Densidade figurativa e graus de especificidade}

Tal como disposta acima, essa sistematização convoca inevitavelmente a questão da extensão das figuras do mundo iconizadas pelos timbres. A seleção do termo "inconfundível" para designar a culminância da densidade figurativa toca - indireta e involuntariamente em um questão numérica. Declarar que uma figura não pode ser confundida com nenhuma outra significa chancelar seu caráter de exclusividade. Em termos quantitativos, isso vale dizer que há uma e apenas uma entidade identificável como fonte sonora desse hipotético timbre. Projetando essa mesma linha de raciocínio na direção oposta, o cenário inverso 

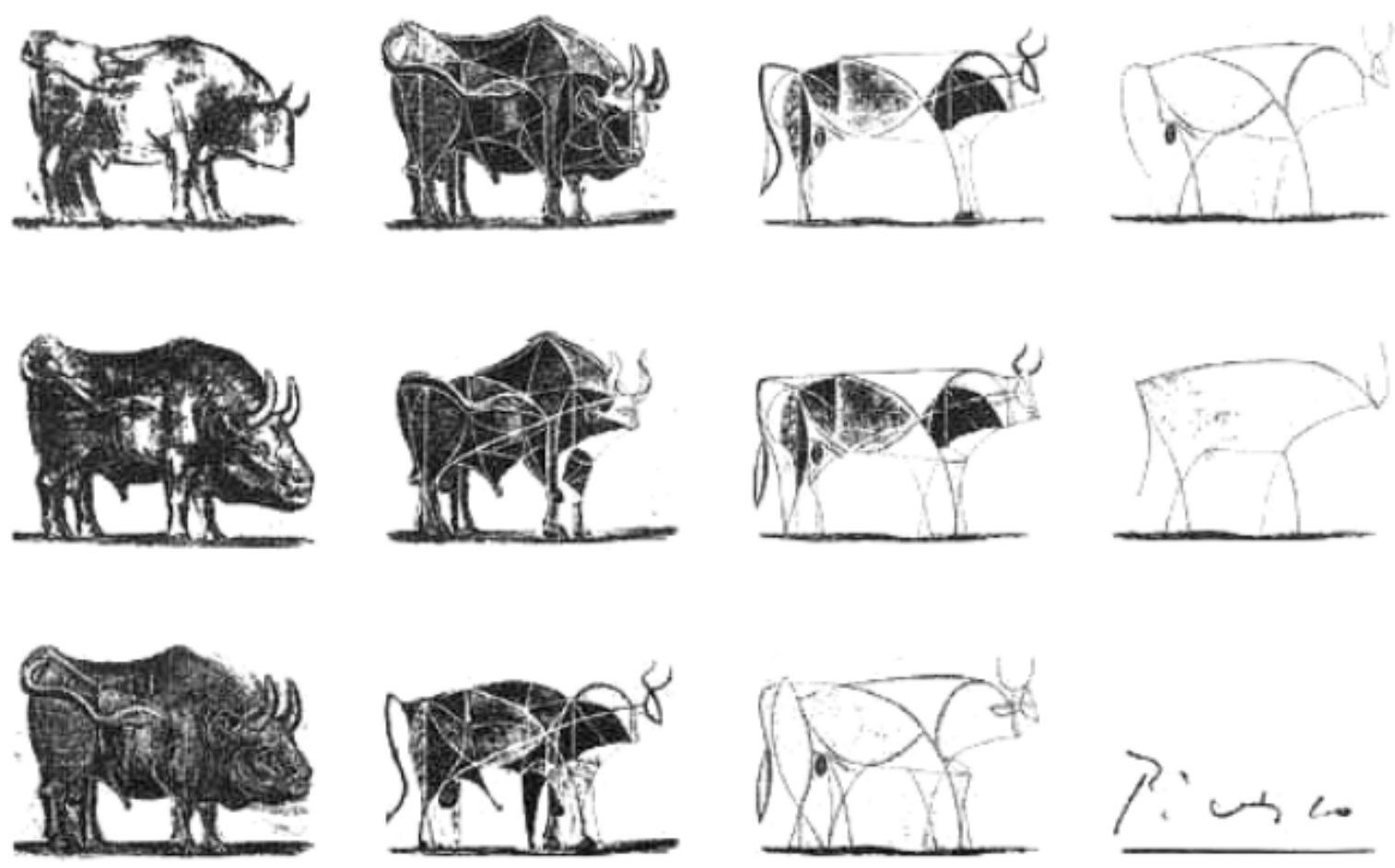

Figura 2.4: Metamorfoses de um touro, de Pablo Picasso. Fonte: Silva (1995,p. 42)

se delineia: timbres de baixa densidade figurativa são irreconhecíveis por remeter a um universo aberto de figuras do mundo. Nesse caso, a impossibilidade de reconhecimento deriva exatamente do não-fechamento do escopo de entidades abarcadas.

Recuperando agora a homologia entre densidade figurativa e grau de especificação já aventada acima (cf. Figura 2.2), pode-se então organizar essa variável quantitativa projetando-a em uma matriz semelhante, inspirada dessa vez na dimensão da extensidade. O modelo para tal é fornecido pela sistematização apresentada em Zilberberg (2012) (cf. Tabela 2.4).

\begin{tabular}{llll}
\hline S1 & S2 & S3 & S4 \\
exclusivo & raro & comum & universal \\
sobrecontrário & subcontrário & subcontrário & sobrecontrário \\
\hline
\end{tabular}

Tabela 2.4: Matriz da dimensão da extensidade. Fonte: adaptado de Zilberberg (2012,p. 73, tradução nossa) e Zilberberg (2011b,p. 79-84)

Uma transposição dessa matriz para o universo dos timbres não permite renomeações senão com muito custo e, talvez, com benefício analítico duvidoso. Sendo assim, convém então justapor a essa escala exemplos concretos de cada termo imediatamente identificáveis em nossa experiência cotidiana e selecionados para fins de mera clareza expositiva (cf. Tabela 2.5). 


\begin{tabular}{llll}
\hline $\begin{array}{l}\text { S1 } \\
\text { exclusivo } \\
\text { sobrecontrário }\end{array}$ & S2 & S3 & S4 \\
saro & subcontrário & subcontrário & $\begin{array}{l}\text { universal } \\
\text { sobrecontrário }\end{array}$ \\
\hline$(?)$ & Violino & $\begin{array}{l}\text { Instrumento } \\
\text { corda friccionada }\end{array}$ & $\begin{array}{l}\text { Evento sonoro contí- } \\
\text { nuo, agudo e pene- } \\
\text { trante }\end{array}$ \\
\hline Chico Buarque & Voz masculina & Voz humana & $\begin{array}{l}\text { Evento sonoro con- } \\
\text { tínuo, médio-grave, } \\
\text { de intensidade mé- } \\
\text { dia, suave etc. }\end{array}$ \\
\hline
\end{tabular}

Tabela 2.5: Matriz da dimensão da extensidade. Fonte: adaptado de Zilberberg (2012, p. 73, tradução nossa) e Zilberberg $(2011 b$,p. 79-84)

O mérito dessa disposição é fazer enxergar que, contrariando o senso comum sobre o tema, o efeito de "impressão digital sonora" subjacente ao reconhecimento de sujeitos únicos e exclusivos é, na verdade, apenas um cenário extremo dentre outros previstos, resultante do máximo grau de densidade figurativa investida no timbre. O exemplo mais emblemático disso é o uso de antropônimos (i.e. Chico Buarque, Frank Sinatra etc.) para etiquetar a fonte sonora do timbre. Um timbre que aponta dubiamente para mais de uma entidade ainda não está suficientemente denso. Encontra-se aqui em pleno âmbito da triagem.

Conforme essa carga sêmica vai se rarefazendo, o timbre passa a instaurar figuras ainda nomeáveis, porém menos específicas. É o que ocorre tipicamente com os instrumentos musicais e suas "famílias". Reconhecer, por trás de um evento sonoro, um timbre de oboé ou de saxofone significa fazer referência a uma classe fechada de figuras, em número restrito e forçosamente maior do que um. A tensão dialética entre esses domínios é sintetizada de maneira lapidar por Parret (2002) quando assim observa:

[...] aprendemos a discriminar o som de uma flauta de um som de um oboé, a sonoridade de uma soprano e a de uma contralto. Mas trata-se aí, evidentemente, de 'classes' convencionais de sons, e não de sons específicos, individuais, idiossincráticos. Não se trata de identificar a voz de uma soprano quando o ouvido é roçado pela voz de Callas, mas sim de identificar a voz de Callas. (Parret, 2002 , p. 101, tradução nossa ${ }^{\mathrm{xxv}}$ )

Se, por recursividade, essa densidade figurativa continuar a se reduzir, então o timbre passará a figurativizar entidades apenas genéricas e não inequivocamente associáveis a uma entidade particular do mundo. É o que ocorre, por exemplo, com o emprego de 
descritores sinestésicos ("áspero", "seco", "brilhante" etc.) que nada mais fazem do que caracterizar vagamente o objeto sonoro. Nesse caso, a extensão das figuras compreendidas pela classe se amplia e as misturas são inevitáveis. Essa articulação entre densidade figurativa e grau de especificidade pode ser sintetizada como uma correlação inversa: quanto mais denso o investimento figurativo do timbre, menos entidades são atribuíveis a ele. ${ }^{16}$

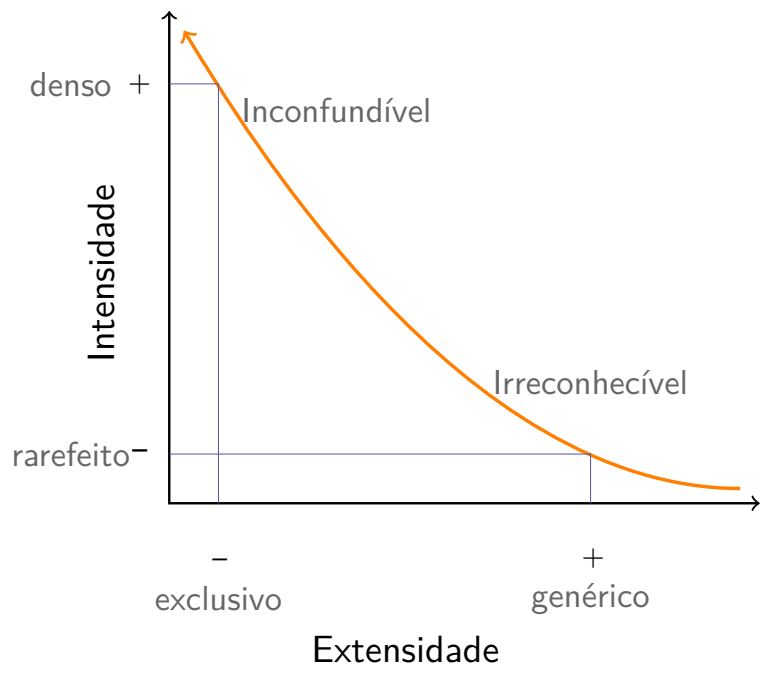

Figura 2.5: Correlação inversa entre densidade figurativa e grau de especificidade. Fonte: elaboração própria.

Não é fortuito constatar que, no estágio máximo de rarefação figurativa, os termos utilizados para designar o timbre são adjetivos. A incapacidade de nomear os timbres é sintoma inequívoco do alargamento do escopo de figuras atribuíveis ao timbre. Essa imprecisão é, aliás, justamente uma das mais citadas causas de incômodo frente a essas adjetivações (Parret, 2002 , p. 41 ss.). Proibindo-nos tal julgamento de valor, estranho ao fazer verdadeiramente científico, reconhecemos aí uma evidência forte que nos permite reinterpretar e ressignificar as duas atitudes descritivas do timbre: nomear e qualificar. ${ }^{17}$

Aparentemente ingênuas em um primeiro momento, essas abordagens parecem escamotear, em surdina, as duas regiões mais salientes do esquematismo tensivo, a saber, os valores de absoluto e os valores de universo (Fontanille \& Zilberberg, 2001, p. 15-59). Transpondo esse dispositivo conceitual ao universo de timbres, os valores de universo

\footnotetext{
${ }^{16}$ Tal alocação dos termos "denso" e "rarefeito" no eixo da intensidade não é unívoca, uma vez que essa oposição pode ser interpretada como uma grandeza da ordem da extensidade. Isso exigiria questionar se o emprego do esquematismo tensivo é imprescindível ao invés de uma correlação inversa simples. Ainda que admitindo a maior elegância teórica dessa reformulação, o modelo como apresentado aqui se baseia em um argumento de natureza terminológica da teoria, conforme apontado adiante nas ressalvas da subseção 2.4.2.
}

${ }^{17}$ Cf. Seção 2.1. 
abarcam as classes de timbres figurativamente rarefeitos e designados por adjetivações. Aqui, as categorias são poucas e amplas. ${ }^{18}$ Por sua vez, os valores de absoluto abrangem os timbres exclusivos, de altíssima densidade figurativa e designados por substantivações (e, no limite, por antropônimos). Aqui, as categorias se multiplicam e as entidades nelas contidas se dividem até atingir o mínimo unitário. Para fins de síntese, pode-se incrementar o esquematismo tensivo apresentado acima acrescentando esses novos achados.

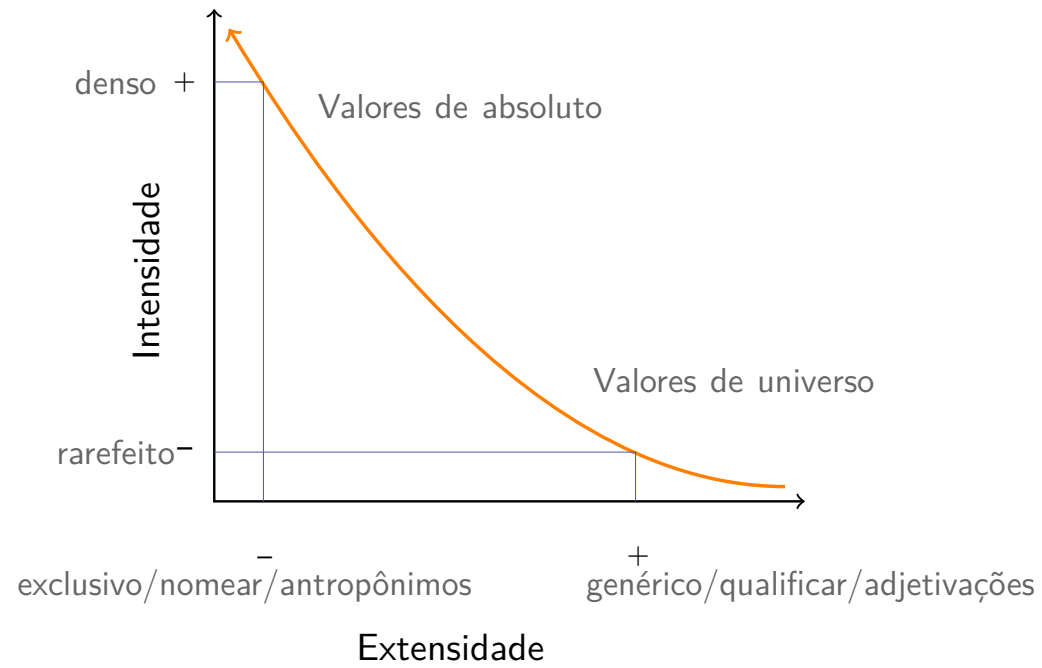

Figura 2.6: Versão enriquecida da correlação entre densidade figurativa e grau de especificação. Fonte: elaboração própria.

É proveitoso relembrar que tal distinção entre diferentes graus de densidade semântica encontra respaldo nos estudos de léxico nas línguas naturais. Desde longa data, a linguística reconhece que certos itens lexicais são mais carregados semanticamente (substantivos, adjetivos, verbos), quando comparados aos itens puramente gramaticais. É, aliás, a vagueza semântica que permite fenômenos como a polissemia e a metáfora. (Cançado, 2008, p. 58-67, 105-107)

O modelo mais bem acabado dessa elasticidade semântica e seu respectivo grau de especificidade nos é oferecido pela categorização dos lexemas em hierarquias de hiperônimos e hipônimos. Porque não convém sacrificar a concisão de nossa exposição para dedicar a esse vasto campo de estudos a merecida atenção, limitar-nos-emos a sintetizar essa estrutura lexical lançando mão de uma representação visual simplificada extraída da literatura da área (cf. Figura 2.7).

\footnotetext{
${ }^{18}$ Cf. Cap. 3.
} 


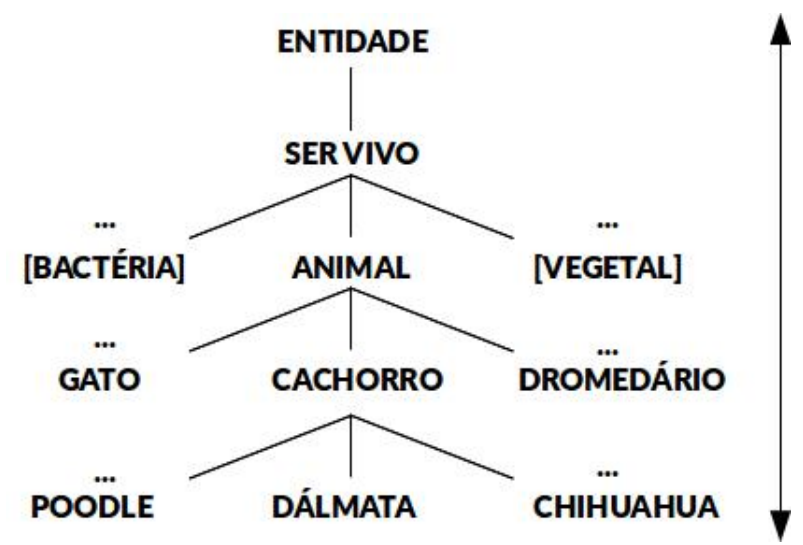

Figura 2.7: Extrato da hierarquia semântica das lexias (centrado em torno de ANIMAL). Fonte: Polguère (2018,p. 161)

A visualização pela arborescência hierárquica explicita com nitidez a relação de inclusão contraída entre hiperônimos e hipônimos. Um lexema é considerado hipônimo de outro quando o conjunto de entidades denotadas pelo primeiro está integralmente contido no conjunto do segundo. Para recobrar um exemplo já dado na Figura 2.7, é o que ocorre com a relação entre POODLE e CACHORRO, assim como entre POODLE e ANIMAL. Parafraseando em termos simples, pode-se sintetizar essa relação de inclusão extensional afirmando que "todo poodle é necessariamente um cachorro", ou então "todo poodle é necessariamente um animal". Conforme a disposição do diagrama, os termos inferiores da hierarquia contraem hiponímia com os termos superiores, seja direta ou indiretamente. Invertendo essa orientação de leitura, deduz-se a relação de hiperonímia. Um lexema é considerado hiperônimo de outro quando o escopo extensional do primeiro contém integralmente o do segundo. Ainda atendo-se ao domínio semântico capturado pelo diagrama, pode-se dizer que SER VIVO é hiperônimo de ANIMAL; igualmente, é válido dizer que ANIMAL é hiperônimo de CACHORRO e também de POODLE, DÁLMATA etc.

Essa hierarquização semântica fornece uma evidência linguística forte que valida nossa categorização do timbre em termos de densidade sêmica/figurativa. De maneira semelhante, a oposição entre hiperônimos e hipônimos é também codificável em termos de enriquecimento semântico: "Diremos que o sentido de um hipônimo é mais rico do que o de seu hiperônimo e, inversamente, que o sentido de um hiperônimo é menos rico do que o de seu(s) hipônimo(s)." (Polguère, 2018, p. 160, grifos nossos). Não poderia ser mais explícita a relação entre hiperonímia-hiponímia e densificação semântica, apresentada, aliás, por conveniente coincidência, por meio de operadores tensivos de aumentos (mais) e diminuições (menos) (cf. Zilberberg, 2011b).

No que diz respeito à variação quantitativa das grandezas selecionadas por hiperônimos e hipônimos, Pietroforte \& Lopes (2004) resumem essa correlação inversa de maneira lapidar: "Esse modo de classificar o mundo envolve um adensamento de semas, 
de modo que a quantidade de semas é inversamente proporcional à extensão do sentido da palavra: quanto mais semas, mais específica é a sua aplicação e vice-versa." (2004, p. 128, grifos nossos). Essa proporcionalidade inversa já tinha sido pontuada, aliás, em Greimas \& Courtés (2012 [1979],p. 123) com base em B. Pottier em termos de compreensão sêmica e extensão de emprego. O mesmo princípio pode ser aplicado ao universo dos timbres. Quanto mais denso o investimento figurativo do timbre, mais específico ele será e, portanto, menor é o número de "fontes sonoras" a ele atribuíveis. Inversamente, quanto menor a densidade figurativa, mais amplo é o escopo de entidades abarcadas.

Embora não diretamente relacionada a essa proporcionalidade inversa, existe ainda uma outra propriedade dessas redes hierárquicas aplicável à análise do timbre. Trata-se do caráter dinâmico das relações entre hiperonímia e hiponímia. Em outras palavras, um dado lexema pode fazer parte de múltiplas redes hiperonímicas ao mesmo tempo, a depender da visada categorizante da análise. Exemplifiquemos: o lexema CACHORRO pode ter como hiperônimo tanto ANIMAL DOMÉSTICO quanto CANÍDEO; no primeiro caso, ele será co-hipônimo de GATO, PAPAGAIO, HAMSTER etc. ao passo que, no segundo caso, ele será co-hipônimo de LOBO, CHACAL, HIENA entre outros. Assim sendo, diferentes redes categorizantes se constroem em torno dos lexemas e o mesmo se dá com os timbres. A título de exemplo, timbres como o de saxofone ou o de trompa podem se relacionar ambiguamente tanto com as madeiras quanto com os metais.

Vê-se, assim, que a categorização de timbres pouco se distancia da organização do léxico na língua. Mais do que apenas uma semelhança superficial fortuita, esse é o desdobramento mais concreto daquela assunção de base que postulava, sem calcular todas as suas consequências, o timbre como "figura do mundo". ${ }^{19}$

\subsection{Advertências sobre o uso do esquematismo ten- sivo e suas diferentes possibilidades de leitura}

Nesse momento, é necessário pontuar algumas ressalvas acerca do emprego do esquematismo tensivo na organização do inventário de timbres conforme proposto aqui. Apesar do ganho analítico propiciado por esse dispositivo teórico, seu emprego acrítico pode gerar resultados pouco proveitosos, tanto para o semioticista atento às máximas exigências epistemológicas, quanto para o musicista e/ou analista interessado em agregar algo de semiótico a seu ferramental analítico. Se é verdade que as lentes teóricas nos fazem enxergar mais e melhor, também é verdade que sua calibragem teórica e metodológica não pode ser negligenciada.

\footnotetext{
${ }^{19}$ Cf. p. 25 ss. acima.
} 


\subsubsection{Sobre a correlação inversa}

A primeira advertência a ser colocada diz respeito à correlação inversa entre densidade figurativa e o grau de especificidade das entidades figurativizadas pelo timbre. O recurso à curva tensiva para articular essas duas valências não deve sugerir nada além do que isso mesmo: uma correlação inversa. Embora supérflua em aparência, essa observação se faz necessária tendo em vista certa tendência a ler a curva tensiva apenas pelo prisma das reflexões de Zilberberg $(2006 b$, 2007, 2011b) sobre o acontecimento. Tal postura interpretativa é menos um imperativo teórico e epistemológico do que um viés de leitura.

Apenas para contextualizar a discussão ao leitor menos familiarizado com os desenvolvimentos recentes da semiótica discursiva, convém recapitular aqui de maneira resumida as grandes balizas teóricas da reflexão sobre o acontecimento conforme traçadas em Zilberberg (2006b, 2007, 2011b, 2012). Resultando da correlação entre o grau máximo de intensidade (sensível) e o grau mínimo de extensidade (inteligível), o acontecimento acomete o sujeito subitamente e apassiva-o em um estado de estupor que esgota sua capacidade de ação e de intelecção. É o que Zilberberg denomina "surpresa", tomando de empréstimo os termos a Valéry. Do lado diametralmente oposto, temos a correlação entre o mínimo grau de intensidade com o máximo grau de extensidade. Sem qualquer prejuízo teórico, a nomenclatura para designar tal situação varia, a depender da fonte consultada, entre fato, exercício, rotina ou estado. Em pleno domínio de si, o sujeito da ação recoloca o sensível sob controle do inteligível e sob a previsibilidade da espera.

Essa grade de leitura se impôs, em larga medida, como consequência da decomposição das dimensões do esquematismo tensivo em suas respectivas subdimensões, nomeadamente tonicidade e andamento para a intensidade, espacialidade e temporalidade para a extensidade (cf. Zilberberg, 2006b). Se, para o semioticista contemporâneo, esse entendimento do aparato teórico parece consensual, também é verdade que ele nem sempre foi hegemônico. Em suas primeiras versões, o espaço tensivo se mostra bem menos atrelado às questões do acontecimento e da experiência estésica do sujeito.

Em Fontanille \& Zilberberg (2001, p. 19 ss.), os gradientes tensivos são concatenados para sistematizar as valorações semióticas subjacentes aos lexemas "cachorro" e "gato" no discurso lexicográfico dos dicionários da língua francesa. Para ser mais específico, a curva tensiva apresentada em Fontanille \& Zilberberg (2001, p. 21) correlaciona profundidade classemática e profundidade tímica. Mais adiante, as valências articuladas são profundidade funcional e profundidade afetiva (2001, p. 24). Segundo a argumentação dos autores, o cruzamento dessas grandezas explica que, nesse domínio discursivo, o cão é valorizado pelas funções que cumpre para o homem, ao passo que o gato é valorizado pelo seu elo afetivo. 
Esse não é, porém, um caso isolado de uso do esquematismo tensivo desvinculado da questão do acontecimento. Em Fontanille \& Zilberberg (2001, p. 47), a curva tensiva é empregada para demarcar o lugar dos sistemas aristocrático e democrático conforme o entendimento de Tocqueville em De la démocratie en Amérique. Sob esse ângulo, a aristocracia se caracteriza pela concentração de valores materiais e sociais a um grupo de extensão restrita. Em contrapartida, a democracia visa a distribuição máxima desses valores para o "bem-estar geral", mesmo ao custo de sua diluição. Nesse momento, a elaboração ainda incipiente dessas ideias constitui um embrião do que viria a ser, mais tarde, desdobrado em detalhes em Zilberberg (2011a, p. 25-49). A representação dessa correlação inversa em uma curva tensiva conforme apresentada em Zilberberg (2011a,p. 30 e p. 67) concretiza, mais uma vez, um uso produtivo desse dispositivo conceitual distante do universo afetivo do sujeito atingido pela surpresa e pelo sobrevir (cf. Figura 2.8).

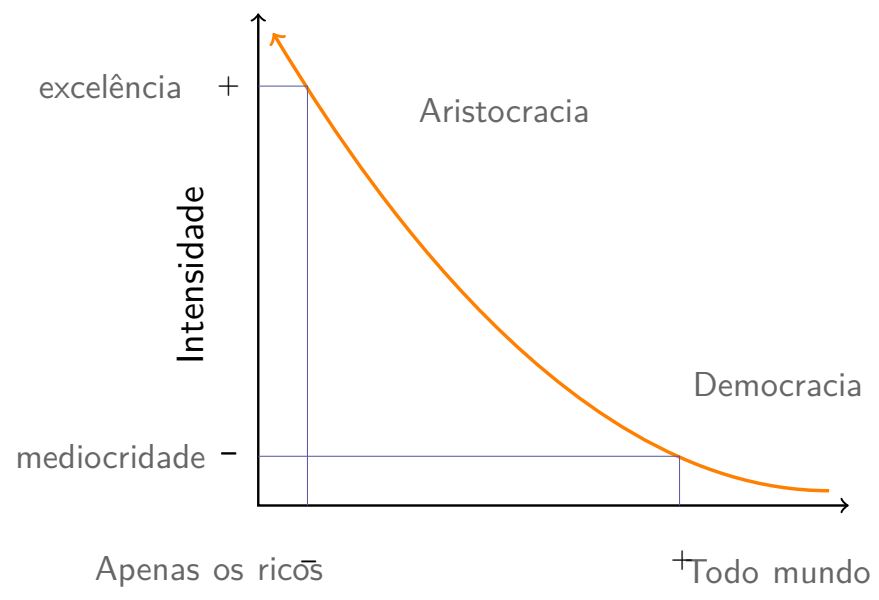

Extensidade

Figura 2.8: Distribuição dos valores sociais nos sistemas aristocrático e democrático. Fonte: Zilberberg (2011a , p. 30, tradução nossa).

Evitando resvalar em uma exposição desnecessariamente exaustiva de contraevidências ${ }^{20}$, pode-se generalizá-las apontando que a usual oposição entre valores de absoluto e valores de universo atesta que nem toda correlação inversa corresponde à dinâmica entre impacto do acontecimento e a re-estabilização do exercício. Se, por contingências de recepção, essa linha de leitura acabou se tornando a preferencial entre boa parcela dos semioticistas, nem por isso ela é a única possível.

\footnotetext{
${ }^{20}$ Cf. Zilberberg $(2011 a$, p. 52, 59, 60, 77)
} 


\subsubsection{Sobre o uso da expressão "densidade figurativa"}

A segunda advertência diz respeito ao uso do termo "densidade" para designar o grau de figuratividade investido no timbre. Em nossa proposta, essa grandeza foi alocada na dimensão da intensidade, domínio próprio do que é da ordem do sensível, do percebido e do massivo. Aos leitores mais rigorosos, não passará despercebido que as acepções de "densidade" e suas variações na língua corrente sugerem uma interpretação como concentração espacial e, portanto, atinente à dimensão da extensidade. Além disso, tal entendimento encontra respaldo também no aparato teórico:

Para a extensidade, voltada para os estados de coisas, ela diz respeito à densidade do campo de presença: se as grandezas forem pouco numerosas, diremos que é a modalidade da concentração que é válida; se for o oposto, diremos que é a modalidade da difusão que será escolhida." (Zilberberg, 2012 , p. 14, tradução nossa ${ }^{\text {xxvi }}$ )

Também corrobora essa linha de leitura a definição do verbete "extensidade" apresentada no glossário dessa mesma obra: "Do ponto de vista tensivo, a dimensão da extensidade tem por tensão geradora: [concentrado vs. difuso]". (Zilberberg, 2012, p. 135, tradução nossa ${ }^{x x v i i}$ ) Tal interpretação não se aplica dentro do estrito horizonte de reflexões sobre o timbre aqui delineado. Se optamos por herdar as designações "densidade (figurativa)", "denso", "rarefeito" e correlatos, é antes por certa postura de respeito à sua anterioridade na literatura da área. De fato, não é outra a expressão empregada em Greimas (1984) para trabalhar a seminal distinção entre icônico e abstrato. Conforme mostrado anteriormente ${ }^{21}$, essa terminologia acabou por se espraiar em outros trabalhos ulteriores em torno da mesma problemática.

Trata-se aqui, antes, de um caso de infeliz coincidência terminológica, em que termos idênticos em superfície remetem a conceptualizações distintas em profundidade. Para evitar mal-entendidos desnecessários, convém conceber o grau de iconização do timbre em termos de alto/baixo investimento figurativo. Uma tal reformulação poderia dissipar associações indevidas da concentração com a extensidade. Porque a lexicalização dos conceitos é menos importante do que a construção de seus mecanismos de base, ficam assinaladas aqui essas considerações apenas como advertência contra eventuais extrapolações falaciosas.

\footnotetext{
${ }^{21}$ Cf. seção 2.2 .2 e especificamente p. 47 ss.
} 


\subsection{Cristalização timbrística como fenômeno discur- sivo}

A organização do repositório de timbres no espaço tensivo goza de grande flexibilidade analítica. Um dos motivos para tal é a conversão dos timbres em valores semióticos, resultantes do cruzamento de valências graduais. Seu caráter continuista permite conceber, com maior coerência e adequação, a porosidade entre categorias e o livre trânsito de timbres entre elas.

Se o modelo aqui proposto consegue atingir tal maleabilidade, é porque ele não pretende impor uma categorização única e universal. Ao contrário, ele é apenas um "molde vazado" a ser preenchido caso-a-caso com os timbres pertinentes a cada domínio particular de aplicação. Essa maleabilidade é propiciada pelo caráter geral das grandezas articuladas no esquematismo tensivo, a saber, grau de especificidade e investimento figurativo.

Isso significa dizer que é impossível determinar a priori quais são os timbres inconfundíveis ou irreconhecíveis. Os candidatos (variáveis) a ocupar essas posições (invariáveis) são atribuídos em parte pelo sujeito, em parte pela norma estética coletiva. É na dialética entre essas duas instâncias que se desenvolve o processo de cristalização figurativa do timbre.

De um lado, os indivíduos gozam de certa margem de liberdade na construção e na organização de seu inventário timbrístico particular. Pelo exercício da intencionalidade (Greimas \& Courtés, 2012 [1979], p. 168), o sujeito se apropria de seu universo sonoro circundante e dele extrai a matéria prima para tipificar os timbres. ${ }^{22}$ Conforme lembram Fontanille \& Zilberberg (2001, p. 23), a organização da categoria e a seleção de seus protótipos exige sempre a inscrição de um sujeito observador. É assim que, por exemplo, aprendemos desde muito cedo a reagir ao timbre vocal de nossos pais e familiares, mas também ao de nossos intérpretes favoritos. Tal variabilidade atesta o caráter construído (e não pré-dado) da cristalização timbrística.

De outro lado, essa liberdade em nível individual encontra seus limites na validação intersubjetiva. O reconhecimento de timbres e sua colocação em discurso precisa necessariamente passar pelo crivo daquilo que é chancelado coletivamente em um dado contexto sociocultural e histórico. ${ }^{23}$ Caso contrário, cairíamos no risco solipsista de categorizar aleatoriamente e a bel prazer o material sonoro do mundo sem qualquer critério

\footnotetext{
${ }^{22}$ Em uma abordagem de forte cunho fenomenológico, Parret (2002) descreve esse processo em termos de contato táctil entre um "corpo-feito-voz" e o corpo próprio do sujeito da percepção, reconceptualizado pelo autor como um "Ouvido-maiúsculo".

${ }^{23}$ Sobre o caráter histórico e social do timbre, recomendamos fortemente o trabalho de Eidsheim (2008, p. 25 ss.) sobre a projeção de marcadores sociais de etnia sobre a voz no canto lírico e popular, bem como o etnocentrismo velado nos julgamentos de valor dela decorrentes.
} 
intersubjetivo de controle. Refletindo sobre o timbre enquanto qualidade vocal, Parret (2002) relembra que essa forçosamente exige, ao lado das condicionantes psicológicas, "uma certa avaliação estética largamente influenciada pela norma cultural" (2002, p. 49, tradução nossa $\left.{ }^{\text {xxviii }}\right)$. Para dizer em termos especificamente semióticos, tais coerções de ordem coletiva se enquadram no domínio da práxis enunciativa (Bertrand, 1993; Fontanille \& Zilberberg, 2001,p. 171 ss.).

Isso explica por que determinados timbres tendem a ser apreendidos como específicos em alguns contextos socioculturais, mas passam despercebidos em outros. É o que acontece tipicamente com locutores de rádio, celebridades, apresentadores de televisão e cantores, mas também com a fisionomia timbrística construída pelos profissionais da voz para personagens de animações e jogos eletrônicos. Esses exemplos são os mais evidentes, pois extremamente sensíveis a variáveis sociais e culturais. Observa-se sem dificuldade que o timbre de um apresentador de televisão ou político é imediatamente reconhecível em determinada região ou camada social e absolutamente ignorado em outra - e vice-versa.

Tal variabilidade apresentada aqui de um ângulo sincrônico se aplica também em perspectiva diacrônica. Com o passar do tempo, uma dada paleta timbrística pode, por hiperespecificação, se compartimentar em novas subdivisões. De maneira semelhante e na direção inversa, ela também pode se subespecificar, passando por um processo de paulatina rarefação figurativa que a condena à indiferença das misturas. ${ }^{24}$

Esse filtro de validação também é decisivo para compreender como a cristalização do timbre em protótipos socialmente reconhecíveis enviesa a seleção de seu respectivo material linguístico e/ou musical de base. ${ }^{25}$ A partir de certo grau de densificação figurativa, o timbre passa a contrair relações mais fortes de (in)compatibilização com a estrutura rítmico-melódica que ele reveste, bem como com a organização morfossintática, lexical e enunciativa do componente linguístico propriamente dito.

Em outras palavras, isso significa dizer que, a despeito de sua ampla margem de variabilidade, a seleção do timbre não é ilimitada. Parcialmente socioletal, parcialmente idioletal, o investimento figurativo do timbre e sua categorização no espaço tensivo é dinâmico, adaptativo e indócil a toda tentativa de esquadrinhamento definitivo. Ao invés de enxergar nessa labilidade uma aporia, é preferível saber usufruir dela.

\subsection{Balanço intermediário}

Chegando a esse ponto, é proveitoso sintetizar os pontos principais da proposta em elaboração. Em primeiro lugar, constatou-se que as descrições de timbre costumam designá-

\footnotetext{
${ }^{24}$ Cf. Cap. 4.

${ }^{25}$ Cf. Cap. 5, seção 5.4.3.
} 
lo ora por nomeação, ora por qualificação. Verificou-se também que essa duplicidade descritiva consubstancia, em superfície, uma oposição profunda entre específico e genérico.

Em seguida, essa oposição foi operacionalizada semioticamente em termos de graus de densidade figurativa. Entre essas duas grandezas, instaura-se uma correlação conversa. Disso decorre que, quanto mais figurativamente denso um timbre, tanto mais específico ele será - e vice-versa. Esse achado vai ao encontro das reflexões semióticas sobre a iconicidade e o efeito de sentido de "realismo" no campo da visualidade e da literatura. Distinguem-se, assim, timbres icônicos e timbres abstratos. Os primeiros são figurativamente densos e instauram fontes sonoras específicas que se deixam facilmente identificar pelo sujeito-ouvinte. Esses timbres são designados por substantivos próprios e substantivos comuns concretos. Os segundos são figurativamente rarefeitos e põem em cena fontes sonoras genéricas, de difícil reconhecimento. Tratam-se daqueles timbres descritíveis apenas por adjetivações.

Por fim, a homologação entre essas duas categorias foi articulada a uma terceira, a saber, a quantidade. Timbres figurativamente densos são raros e pouco numerosos; timbres figurativamente rarefeitos são comuns e muito numerosos. Essa correlação conversa tem como corolário a designação de timbres exclusivos por meio de antropônimos. Em via de regra, um nome próprio deve denotar uma e apenas uma entidade do mundo. Prova cabal disso é a consequente ampliação numérica ocasionada pela figura retórica da antonomásia. ${ }^{26}$

No domínio do timbre, o mesmo se dá com comediantes "imitadores de voz". Não por acaso, os timbres mais frequentemente imitados são também aqueles mais idiossincráticos. Só são passíveis de imitação timbres exclusivos e/ou com altíssima densidade figurativa. Caso contrário, não haveria aí nada a ser imitado, uma vez que o mérito da imitação é justamente atingir a maior semelhança possível. Assim, o comediante acaba por forçar, ainda que involuntariamente, uma transformação em classe daquilo que era até então apenas elemento. Vê-se, assim, como o modelo teórico é corroborado, e não refutado, pela miríade de cópias vocais ${ }^{27}$ (ainda que imperfeitas) de "Sílvios Santos" e "Galvãos Buenos", entre outros timbres tornados célebres no contexto sociocultural brasileiro.

\footnotetext{
${ }^{26}$ Reboul (1998,p. 122) define sucintamente a antonomásia como uma "sinédoque que consiste em designar uma totalidade ou uma espécie pelo nome de um indivíduo considerado seu representante". Tringali $(1988$, p. 136) exemplifica de maneira direta e concisa: "Em vez de dizer que uma pessoa é hipócrita, digo: 'é um Tartufo'. Tartufo é um personagem teatral que se caracteriza pela hipocrisia de um modo destacado. O personagem se notabiliza tanto pela qualidade que seu nome [próprio] se torna comum. Dizemos de um bom orador que ele é um Cícero". A antonomásia extrai as propriedades semânticas mais salientes do antropônimo para fundar uma classe de elementos. Cf. também Fontanier (1968, p. 95-97), Flaux (1991); Siblot \& Leroy (2000); Noailly (2005); Jonasson (1991).

${ }^{27} \mathrm{~A}$ técnica de imitação é empregada pela fonética experimental para aferir a modulação de parâmetros acústicos em disfarces vocais (cf. Passetti \& Barbosa, 2018).
} 
Conclusões dessa natureza levantam mais evidências do caráter inelutavelmente culturalizado e discursivo do timbre, em detrimento de suas condicionantes materiais. O fenômeno da imitação é particularmente revelador uma vez que seu sucesso depende em larga medida do fazer-veridictório do sujeito-ouvinte na posição de enunciatário. É nesse domínio que se processa o reconhecimento dos timbres - para muito além do cenário anedótico dos imitadores de voz. Sem a participação ativa do sujeito, torna-se impossível a categorização de timbres em genéricos e específicos, bem como todos os efeitos de sentido dela decorrentes.

Assim, impõe-se como fio condutor da presente investigação a categorização em termos de grau de especificidade e de densidade figurativa. Essa é a espinha dorsal que sustenta todo o corpo de desdobramentos analíticos efetuados daqui em diante. Uma segmentação aproximativa dessa escala de especificidade resulta em duas regiões extremas de máximo e mínimo investimento figurativo, interpoladas por uma região intermediária. Esses macro-domínios também se distinguem pela coerção combinatória posta entre a estrutura linguístico-musical do enunciado e o timbre selecionado para revesti-lo.

Densidade mínima No nível mínimo de densidade figurativa, o timbre é inespecífico e só permite o reconhecimento de qualidades abstratas, manifestas na forma de adjetivos sinestésicos. Aqui, as categorias são amplas e heterogêneas, pois selecionam apenas os denominadores comuns mais elementares, usualmente o perfil temporal do objeto sonoro (ataque, sustentação e decaimento). Como consequência, congregam-se timbres aparentemente discrepantes entre si. ${ }^{28}$

Quando o timbre é figurativamente rarefeito, são minimizadas também suas restrições de compatibilização com o substrato linguístico-musical do enunciado. Esse cenário corresponde à livre permutabilidade do timbre prevista em Tatit (1997, p. 158). Nele, a seleção do timbre é indiferente e não-distintiva, configurando uma substituição (cf. Hjelmslev, 2006 [1943], 1991). No quadro teórico da semiótica greimasiana, essa livre variabilidade pode ser convertida em modalidades deônticas na fórmula /não-deverser/+/não-dever-não-ser/.

Densidade intermediária No patamar intermediário, a densidade semântica já permite uma discretização mais refinada do que aquela propiciada pelo perfil temporal do timbre. O investimento semântico é maior do que o mínimo, porém ainda pode deixar certa margem de indefinitude quanto à atribuição da fonte sonora. É o que acontece quando um certo registro timbrístico iconiza indecidivelmente duas ou mais entidades, à maneira de uma polissemia lexical nas línguas naturais. Sua desambiguização exige a colocação em

\footnotetext{
${ }^{28}$ Cf. Cap. 3.
} 
contexto. Nesse estágio, pode-se identificar grandes famílias timbrísticas, designadas por substantivos comuns: flauta, violão, saxofone, voz, marimba, vibrafone etc. As fronteiras entre essas famílias podem ser mais bem delineadas verificando sua (in)compatibilidade intertimbrística mútua, semioticamente traduzíveis em termos de triagens e misturas. ${ }^{29}$

Essa linha de investigação encontra um parentesco distante no estudo de Fontanille (2001) sobre a pátina e sua função de instaurar uma coesão figurativa e uma "concordância" subreptícia entre objetos (2001, p. 33 ss.). Essa frente de trabalho possibilita conferir um tratamento isotopante às restrições de seleção e combinação em nível intertimbrístico. Essa é uma consequência direta da premissa de base avançada por Dietrich (2008) que concebe o timbre como "figura do mundo". ${ }^{30}$ Quando põe em cena as compatibilidades e incompatibilidades entre timbres, essa perspectiva abre caminho para o estabelecimento de um sistema autônomo do universo timbrístico, articulado em torno de relações contratuais e polêmicas contraídas no espaço sonoro.

Densidade máxima No último grau de densidade semântica, encontramos os timbres atribuídos a entidades únicas e exclusivas no mundo natural. Frequentemente, esses timbres são designados por nomes próprios. É o que acontece com timbres célebres (seja na música ou na mídia comercial) e também com pessoas de nosso convívio social mais próximo.

Timbres com alta densidade figurativa assumem a propriedade de ativar operações enunciativas concorrentes e paralelas àquelas desencadeadas pelo aparelho formal da enunciação. Aqui, a troca de revestimento timbrístico pode neutralizar ou contradizer o efeito de autenticidade gerado pela ilusão enunciativa. ${ }^{31}$ Nesse cenário, o timbre é suscetível à operação de comutação, para resgatar os termos de Hjelmslev (2006 [1943]). Essa força coercitiva de prescrições e interdições do revestimento timbrístico se deixa traduzir na fórmula modal /dever-ser/+/dever-não-ser/.

Essas coerções combinatórias com o substrato linguístico-musical assumem também outras formas. Em âmbito propriamente musical, trata-se do que se conhece comumente por "linguagem do instrumento". Nesse cenário, o timbre contrai compatibilidade preferencial com determinadas configurações rítmico-melódicas, avaliadas como mais "idiomáticas", em detrimento de outras, tidas por inusitadas ou desusadas. Sua contraparte linguística se manifesta como constituição duplamente orientada do éthos do sujeito. Em outras palavras, os semantismos do componente linguístico (isotopias temáticas, figurativas, perfis patêmicos etc.) se calcificam no timbre que os profere; ao mesmo tempo, o timbre também projeta sobre o conteúdo linguístico sua sombra ética. Para garantir visão

\footnotetext{
${ }^{29}$ Cf. Cap. 4.

${ }^{30}$ Cf. Cap. 1, p. 25.

${ }^{31}$ Cf. Cap. 5.
} 
de conjunto, convém agora sintetizar visualmente esses achados (cf. Tabela 2.6).

\begin{tabular}{cll}
\hline - Específico & Densidade figurativa mínima & $\begin{array}{l}\text { Envelope sonoro, perfil temporal, } \\
\text { qualificativos sinestésicos }\end{array}$ \\
& Densidade figurativa intermediária & Constituição de famílias timbrísti- \\
& & cas, (in)compatibilizações intertim- \\
& brísticas, triagens e misturas \\
+ Específico & Fensidade figurativa máxima & Fontes sonoras exclusivas, designa- \\
& ção por antropônimos, operações \\
& enunciativas desencadeadas pelo \\
& timbre \\
\hline
\end{tabular}

Tabela 2.6: Quadro sinóptico das macrozonas de densidade figurativa do timbre. Fonte: elaboração própria

Avanços É preciso relembrar aqui que essas zonas de especificação se divisam por fronteiras porosas. Por um processo de particularização ${ }^{32}$, o timbre pode ir ganhando densidade figurativa e rumar, assim, ao patamar mais profundo de especificidade. Na direção oposta, um timbre pode perder em densidade figurativa. Em decorrência disso, ele passa a se generalizar e fundar uma família. Nesse caso, ele se torna o melhor exemplar de um conjunto que abarca outros integrantes assemelhados, no que arriscamos designar como uma antonomásia sonora. ${ }^{33}$

Assim sendo, um dos avanços conquistados por essa perspectiva é resolver a tensão criada pela natureza dúplice do timbre, apontando ora para a identificação de uma entidade no mundo natural, ora para uma identidade apenas genérica, descrita em termos de qualidade sensíveis. Até então, as tipologias de timbres se limitavam a apresentar recortes mais ou menos arbitrários, seguindo critérios de ordem acústica ou articulatória. A despeito dos diferentes níveis de complexidade e refinamento, tais categorizações sempre resultavam estáticas e insuficientes para lidar com timbres que escapam às divisões já estipuladas de antemão.

\footnotetext{
${ }^{32}$ Mesmo sem recorrer ao conceito greimasiano de figuratividade, também Eco (2008) chega a uma semelhante conclusão ao refletir sobre as relações entre reconhecimento, memória e particularização de indivíduos: "Esse é o único mecanismo por meio do qual somos capazes de reconhecer hoje alguém com quem nos tenhamos encontrado dez anos atrás mesmo que seu peso, a quantidade de pelos de sua barba, as rugas em seu rosto ou o número de seus dentes tenham mudado. Reconheço $\mathrm{X}_{1}$, objeto de minha percepção atual, como sendo o mesmo que $\mathrm{X}_{2}$, objeto de minha percepção passada, se eu tiver conservado na memória um tipo abstrato X que levou em conta apenas alguns traços pertinentes. (...) Não há regra geral para estabelecer os critérios de pertinência. Estes dependem de várias exigências práticas. Um comandante que necessite mandar três soldados atacar o inimigo, requer poucos traços pertinentes para reconhecer um soldado: presumivelmente idade mediana, sexo masculino e um uniforme. O comandante não está interessado nas diferenças entre Paulo, Pedro ou José. Já um jovem apaixonado que procurá reconhecer a amada depois de muitos anos, exige um número maior de traços pertinentes." (Eco, 2008 ,p. 192).

${ }^{33}$ Cf. p. 64 acima.
} 
Com o esquematismo tensivo, essa limitação é superada pois ele mobiliza propriedades suficientemente gerais que garantem o caráter dinâmico da categorização. Esse avanço só pode ser conquistado quando se entende que não compete à ferramenta analítica decretar quais e quantos são os timbres. Ao contrário, ela deve apenas fornecer um modelo de previsibilidade que satisfaça as mais diversas condições de aplicação. Tal perspectiva recupera um dos princípios de Hjelmslev (2006 [1943] ,p. 20) quando advoga que uma linguística geral não deve descrever essa ou aquela língua particular, mas sim os mecanismos subjacentes a todas as línguas naturais. Tendo erigido a escala de especificidade e densidade figurativa como pilar central de sustentação conceitual, cumpre agora assentar as bases de cada patamar de investigação que nele se apoiam.

\section{Citações traduzidas no original}

xvii "We often explain our perceptions by simply naming the sound source as our label for timbre, or through a combination of metaphor, onomatopoeia, vocal mimicry, and gesture. We might use cross-modal metaphors like 'bright' or 'harsh' to describe these sensory impressions, with varying degrees of agreement between listeners as to the specific meaning of these terms." (Heidemann, 2016,p. 3)

xviii "La perception apparaît, dans ce sens, comme le lieu stratégique priviliégié pour une enquête sémiotique, car elle désigne ainsi les principales directions à la fois de l'abstraction et de la concrétisation de la recherche. Ceci une fois admis, on peut ensuite procéder par induction, en partant des figures iconisées que l'on trouve dans les textes, pour les déshabiller en quête du figuratif plus profond qui serait sous-jacent aux icônes." (Keane, 1991,p. 15)

xix "Il faut cependant remarquer que cette définition du figuratif présuppose l'existence d'une segmentation du plan de l'expression du monde naturel en éléments reconnaissables pour qu'une correspondance puisse être établie. Or la notion d'éléments reconnaissables' pour dépend de la culture du lecteur : [...] . L'idée d'élément' suppose l'existence d'une grille d'interprétation du monde, [...]." (Bastide, 1983,p. 16) xx“[...] : la figure est un élément du monde que n'est reconnaissable que dans un discours particulier." (Bastide, 1983, p. 17)

xxi "C'est cette grille [figurative] de lecture qui nous rend le monde signifiant en permettant d'identifier les figures comme des objets, de les classer, de les relier entre eux, d'interpréter les mouvements comme des procès, attribuables ou non à des sujets, etc. : de nature sémantique - [...] - elle sert de 'code' de reconnaissance qui rend le monde intelligible et maniable." (Greimas, 1984, p. 9)

xxii "L'iconisation et l'abstraction ne sont donc que des degrés et des niveaux variables de la figurativité." (Greimas, 1984, p. 11)

xxiii "Les résidus irréductibles de l'analyse fonctionnelle ont ceci de commun, de dénoter ce qu'on appelle couramment le « réel concret »."(Barthes, 1968,p. 87)

xxiv "Le déroulement de ce discours [référentiel] prenant en compte un nombre de plus en plus élevé de figures 'gestaltiques', leur densité sémique augmente, permettant de parler alors de figures iconiques et de l'iconisation du figuratif." (Greimas, 1983a,p. 49)

xxv [...] on a appris à discriminer le ton d'une flûte du ton d'un hautbois, la tonalité d'une soprano et d'un contralto. Mais il s'agit là évidemment de «classes» conventionnelles de tons, et non pas de tons spécifiques, individuels, idiosynchratiques. Il ne s'agit pas d'identifier la voix d'une soprano quand l'oreille 
est chatouillée par la voix de Callas, mais d'identifier la voix de Callas. (Parret, 2002, p. 101)

xxvi "Pour l'extensité, tournée vers les états de choses, elle a affaire à la densité du champ de présence : si les grandeurs sont peu nombreuses, nous dirons que c'est la modalité de la concentration qui est valide ; si c'est l'inverse, nous dirons que c'est la modalité de la diffusion qui sera retenue." (Zilberberg, 2012 ,p. $14)$.

xxvii "Du point de vue tensif, la dimension de l'extensité a pour tension génératrice : [concentré vs diffus]". (Zilberberg, 2012 ,p. 135)

xxviii [il faut pour qu'il y ait qualité, également des déterminants psychologiques concernant la personnalité, l'émotivité, le tempérament, le goût,] et même une certaine évaluation esthétique largement influencée par la norme culturelle. (Parret, 2002,p. 49) 


\section{Capítulo 3}

\section{TIMBRE E TEMPORALIDADE}




\section{Capítulo 3}

\section{Timbre e temporalidade}

\subsection{Pontos de partida}

Desde as reflexões de Lessing ${ }^{1}$, é senso comum assumir a música como uma arte do tempo por excelência. O entendimento de que a música depende necessariamente do decorrer temporal é facilmente reconhecível no devir melódico (alturas), nas repetições e desdobramentos de motivos rítmicos (durações) e nas nuanças dinâmicas de crescendo e decrescendo em uma peça (intensidade).

Tal reflexão despretensiosa pode nos levar à seguinte questão: é possível também reconhecer uma temporalidade subjacente ao timbre? Assumir aprioristicamente que o timbre comporta uma temporalidade em si apenas por pertencer a uma arte do tempo seria uma opção cômoda. Ainda que pareça um juízo aceitável à primeira vista, a coerência teórica e empírica de tal proposição deve ser posta à prova com o ferramental analítico da semiótica. Mais do que deliberadamente proclamar esse caráter temporalizante, é preciso acima de tudo verificar como ele opera e em que medida ele possibilita uma descrição mais simples (do ponto de vista da teoria) e mais adequada (do ponto de vista da aplicação empírica). Para ilustrar a falta de consenso acerca dessa problemática, daremos voz a um dos mais proeminentes semioticistas da música:

O Tratado dos objetos musicais de [Pierre] Schaeffer apenas faz um inventário de uma taxonomia de objetos, o que já é muito, entretanto não chega a propor uma sintaxe, sem a qual não pode existir uma linguagem. Por quê? Talvez porque o timbre, diferentemente da altura e do ritmo - parâmetros lineares e horizontais que ordenam uma sequência temporal e exigem, de modo imperioso, prolongamentos -

\footnotetext{
${ }^{1}$ Remetemos aqui à clássica divisão entre artes do tempo (música, poesia, dança e teatro) e artes do espaço (pintura, arquitetura) proposta por esse filósofo.
} 
possua uma dimensão vertical, sendo petrificado no tempo $e$ incapaz de criar por si mesmo um devir. Objetos, definidos unicamente em função de suas propriedades timbrísticas e morfológicas, não podem gerar uma sintaxe, implícita ou explícita. (Nattiez, 2005 , p. 250-251, grifos nossos)

Em outro momento, Nattiez (2005) lança mão de uma categoria binária do tipo ruído vs. som para afirmar que, por estar intimamente entrelaçado com os demais parâmetros musicais, o timbre assume caráter monolítico e, por isso, é incapaz de produzir sentido por si só (cf. Nattiez, 1990 apud Reed, 2005, p. 16, nota de rodapé 29). A oposição colocada por Nattiez entre parâmetros "horizontais" (altura e ritmo) e parâmetros "verticais" (timbre) remete à ideia amplamente difundida acerca da impossibilidade de organizar o universo de timbres existentes em uma escala linear unidimensional (cf. Krumhansl, 1989). No entanto, a declarada impossibilidade de gerar "sintaxe implícita ou explícita" pelo timbre precisa ser investigada pelo semioticista, já habituado a depreender desdobramentos de tipo sintático desde o princípio de linearidade de Saussure (1991 [1916],p. 842)2 ${ }^{2}$, passando pela "capacidade memorial" das operações do quadrado semiótico (Greimas \& Courtés, 2012 [1979], p. 475), pelos desdobramentos sintagmáticos da narratividade (Greimas \& Courtés, 2012 [1979] , p. 328, 336; 475-477) e indo até ao pensamento essencialmente temporalizado de Zilberberg (2011b, 2006a,b, 2011a,b).

A ideia de timbre como unidade monolítica indivisível remete também à já consagrada concepção de "cor do som" (cf. Howard \& Angus, 2006, p. 217; Kennedy, 1996 ,p. 153 e Dahlhaus \& Eggebrecht, 2001,p. 296-298). Costumeiramente, tanto timbre como cor tendem a ser considerados como grandezas estáticas não-analisáveis. ${ }^{3}$ Todavia, o mesmo Tratado dos objetos musicais citado por Nattiez (2005) serviu também de referência ao compositor Flo Menezes (2003) para argumentar que, do ponto de vista acústico, a percepção de timbres depende forçosamente do desenvolvimento temporal do envelope dinâmico sonoro (2003, p. 173, 205-231).

Essa divergência de leituras do Tratado dos objetos musicais de Schaeffer (2002) deixa claro que a atribuição de um caráter temporal ao timbre é antes uma questão de visadas distintas do objeto. Enquanto Nattiez (2005) opõe o timbre ao devir harmônico, melódico e rítmico tipicamente estruturantes na composição, Menezes (2003) traça suas reflexões sobre o pano de fundo da música eletroacústica, a qual alça o timbre a um patamar privilegiado. Para além dos universos estéticos distintos vislumbrados por esses autores, cabe-nos nesse momento recuperar brevemente o entendimento de timbre corrente

\footnotetext{
${ }^{2}$ Cf. especialmente a leitura crítica apresentada em Lindenberg Lemos (2017)

${ }^{3}$ Cf. por exemplo a discussão sobre "primitivos cromáticos" em Thürlemann (2004,p. 93-97). Ainda a esse respeito, a análise de Zilberberg (2008) explicitando cifras tensivas subjacentes aos diferentes tons de rosa sugere que o mesmo procedimento poderia, em princípio, ser aplicado também ao timbre.
} 
nos trabalhos da Semiótica da Canção para, em seguida, buscar uma resolução mediadora desse impasse.

\subsection{A temporalização do timbre em semiótica da can- ção}

Segundo Tatit (2007, p. 256-260), o timbre funciona como um elemento de presentificação enunciativa necessário para a manifestação do texto cancional. Tratado como um prolongamento do corpo do sujeito, o timbre co-participa dessa dilatação da duração do presente efetuada pelo momento de execução $\left(2007\right.$, p. $260^{4}$ ). Tal constatação revela, no entanto, pouco sobre a temporalidade do timbre. No caso dos parâmetros de altura, duração e intensidade, os efeitos da temporalidade foram abordados em termos de concentrações e expansões operadas pelo andamento (cf. Tatit, 1997). Nessa esteira, pode-se bem perguntar se é possível temporalizar o timbre nesses mesmos termos. Se sim, em que medida essa abordagem seria compatível com o tratamento já dado aos demais elementos - melodia, ritmo, letra?

Partindo em busca dessas respostas, o trabalho de Coelho (2007) propôs uma tipologia dos instrumentos musicais de acordo com a sua capacidade de sustentar o som (Coelho, 2007 , p. 130-136). Retomando o papel do andamento e das durações nos processos de tematização, passionalização e figurativização conceptualizados por Tatit (1997), o autor propõe que o arranjo de canções tematizantes (regidas pelo andamento acelerado) tende a privilegiar instrumentos com menor capacidade de duração, denominados "percussivos". Por sua vez, nas canções passionalizantes, o arranjo congregaria instrumentos com maior capacidade de duração, denominados "melódicos" (cf. Coelho, 2007 , p. 132). Consequentemente, os termos subcontrários do quadrado semiótico recobrem as categorias não-melódico e não-percussivo (cf. Figura 3.1).

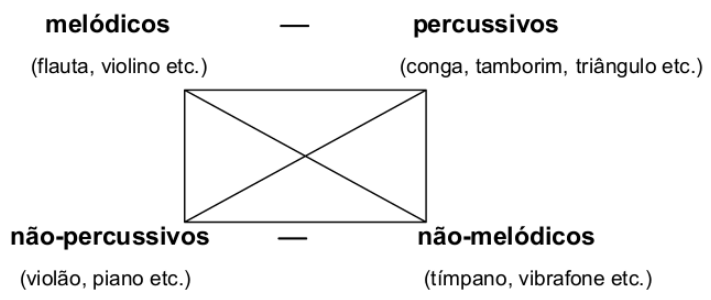

Figura 3.1: Quadrado semiótico da tipologia dos instrumentos musicais conforme seu ataque e sua capacidade de sustentação. Fonte: Coelho (2007,p. 131).

${ }^{4}$ Cf. Cap. 1.2.1, p. 16. 
Em primeiro lugar, vale ressaltar aqui que a abordagem de Coelho (2007) se apoia sobre uma forma ideal do timbre em sua manifestação prototípica. Não se ignora que os instrumentos assim como circulam no mundo empírico são capazes de produzir uma múltipla gama de sons. ${ }^{5}$ Trata-se aqui de uma abstração depreendida das manifestações de cada instrumento tornadas mais canônicas pela prática musical ocidental.

Banal apenas em aparência, essa observação é crucial para uma abordagem semiótica do timbre na medida em que o considera como uma unidade formal autônoma emancipada de suas realizações materiais contingentes. No fundo, a proposta de Coelho (2007) consiste em categorizar timbres instrumentais a partir de sua configuração morfológica, construída de maneira abstrata e geral a partir de dois critérios: o modo de ataque (percussivo vs. não percussivo) e sua duração (melódico vs. não-melódico).

\subsection{Uma proposta de reformulação}

Apesar de derivar adequadamente os termos contrários e contraditórios de seu quadrado semiótico, o resultado final da proposta de Coelho (2007) traz alguns dados que podem ser questionados, especialmente com relação aos termos subcontrários (denominados não-percussivos e não-melódicos). A esse respeito, Coelho (2007) argumenta que instrumentos como violão e piano negam o seu caráter percussivo em favor de sua natureza melodizante, isto é, de sua capacidade de produzir sons com altura definida e construir melodias com eles. Por isso, eles deveriam ser categorizados no polo dos instrumentos não-percussivos. Simetricamente, em percussões de altura definida, como o tímpano e o vibrafone, é o seu caráter percussivo que ganha proeminência (Coelho, 2007, p. 131). Em ambos os casos, a percussividade e a melodicidade dos instrumento são tratadas por esse autor em termos de "caracteres recessivos" e "caracteres dominantes".

Apesar de satisfazer as regras da sintaxe fundamental do quadrado semiótico, categorizar o timbre do piano como não percussivo é contrassensual. Para além da sua capacidade de fazer sustentar seu som, é arriscado dizer que seu caráter percussivo é negado sem resvalar em discussões ora sobre a anatomia do instrumento, ora sobre os diversos estilos de composição e execução. ${ }^{6}$ Levando às últimas consequências a oposição entre caracteres dominantes e recessivos trabalhada por Coelho (2007,p. 131), é razoável perguntar então: no caso do piano, qual característica deveria ser considerada dominante: a percussividade de seu ataque ou sua sustentação sonora?

Antes de optar precipitadamente por uma ou outra via, é interessante desdobrar

\footnotetext{
${ }^{5}$ Pode-se mencionar aqui as técnicas estendidas para cada instrumento, as composições para piano preparado entre outros exemplos.

${ }^{6}$ Em Bela Bartók, por exemplo, o piano assume um caráter destacadamente percussivo; o mesmo já não poderia ser dito do piano presente nas obras de Claude Debussy ou Erik Satie, por exemplo.
} 
ainda essa mesma questão considerando as percussões de altura definida (como tímpano, vibrafone, metalofone entre outros) e as cordas beliscadas/dedilhadas (como violão, harpa, cavaquinho entre outros): seriam elas instrumentos melódicos que ganham certo grau de percussividade ou antes instrumentos percussivos que ganham certo grau de melodicidade? Extrapolando esse espectro de possibilidades, pode-se vislumbrar o cenário oposto e interrogar: seriam esses casos de instrumentos melódicos aos quais é subtraído certo grau de melodicidade? Ou ainda, analogamente: pode-se falar em instrumentos percussivos aos quais é subtraído certo grau de percussividade? ${ }^{7}$

Nesse momento, é preciso frisar que tal impasse sobre a negação e a asserção do caráter percussivo ou melódico do timbre dos instrumentos decorre do fato de que a tipologia de Coelho trabalha, na verdade, com duas propriedades distintas: o modo de ataque do som (percussividade) e a sustentação do som (melodicidade). Essa denominação comporta alguns problemas na medida em que trata como "melódico" a capacidade de sustentação do som, embora não se trate exatamente da mesma propriedade. Pode-se questionar se sons com longa sustentação e altura indefinida deveriam ser considerados como melódicos, como é o caso do sibilar constante de aparelhos de ar-condicionado, chuveiros elétricos e o farfalhar de folhas. Da mesma maneira, sons de brevíssima sustentação (cliques, estalos e estampidos) podem ser sequencializados de modo a construir o efeito de sentido de melodia. Essa dedução é corroborada pela descrição que Almada (2014 [2000], p. 73) faz do bandolim, atribuindo seu caráter essencialmente melódico ao aspecto percussivo de sua "natural agilidade".

Uma possível saída para o dilema é oferecida pelo quadrado semiótico de segunda geração, cuja articulação de eixos semânticos resulta em um termo complexo (s1+s2), um termo neutro (não·s1+não·s2), uma dêixis positiva (s1+não·s2) e uma dêixis negativa (não·s1+s2) (Greimas \& Courtés, 2012 [1979],p. 403). ${ }^{8}$

Nessa reformulação, a oposição de base entre sustentação sonora (referida provisoriamente até aqui como "melodicidade") e proeminência de ataque (sua "percussividade" ') geraria então quatro categorias. No termo complexo $(\mathrm{s} 1+\mathrm{s} 2)$ seriam agrupados os timbres que portam um ataque e sustentação sonora bem marcados: é o caso de grande parte das cordas beliscadas (como o violão, a harpa entre outros), das percussões com altura definida (incluíndo aí o piano) e também, ainda que de maneira menos evidente, das cordas friccionadas (violino, viola, violoncelo, etc.). Por sua vez, o termo neutro

\footnotetext{
7 Pode-se conjecturar aqui a possibilidade de aplicação do esquematismo tensivo na organização desses dados. Devido aos limites desse trabalho, essa linha de investigação poderá ser desenvolvida apenas em trabalhos futuros.

8 Não é demasiado frisar que as denominações "positivo" e "negativo" indicam originalmente apenas a axiologização dos termos no quadrado e não implicam qualquer julgamento de valor apriorístico. Para nossos propósitos nesse trabalho, essa denominação não tem qualquer consequência exceto designar os termos posicionados usualmente à esquerda e à direita do quadrado semiótico de segunda geração.
} 
(não·s1+não·s2) recobriria os timbres que não possuem um ataque bem marcado e também não se estendem na duração. No limite, o termo neutro implica a própria anulação da pertinência da categoria (Greimas, 1976 [1966] , p. 35). Por isso, essa posição da estrutura dificilmente encontra exemplo em ocorrências empíricas.

Na dêixis negativa ( $1+$ não·s2), seriam reunidos os timbres com capacidade de longa sustentação, porém sem ataque destacado. Exemplos concretos são os aerofones (flauta, saxofone, clarinete, acordeão, órgão de tubo etc.) e também o suave toque da baqueta apelidada popularmente de "vassourinha", utilizada em larga medida na bossa nova e em certas correntes do jazz. Nesse caso também poderiam ser considerados os diversos tipos de sons contínuos, tais como o ruído branco ${ }^{9}$, o ruído rosa, e outras formas de "perfumes sonoros" usados para mascarar o ruído ambiente (Schafer, 2011,p. 145). Por fim, a dêixis positiva (não·s1+s2) congregaria os timbres com ataque bem marcado porém com fraca capacidade de se sustentar no tempo, como é tipicamente o caso das percussões sem altura definida: pandeiro, conga, agogô entre tantos outros (cf. Figura $3.2)$.

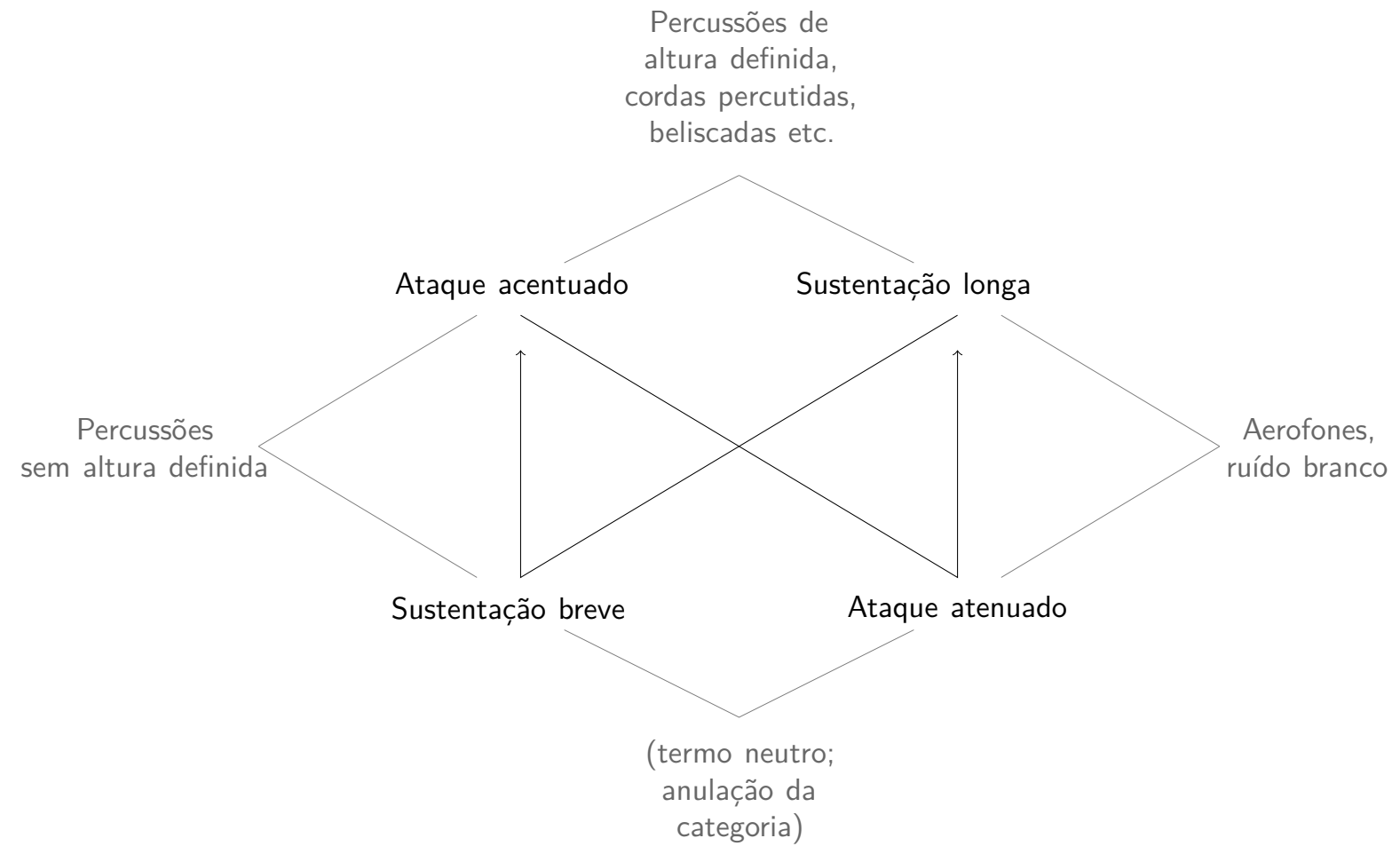

Figura 3.2: Quadrado semiótico de segunda geração articulando ataque e extinção do som. Fonte: elaboração própria com base em Greimas \& Courtés (2012 [1979], p. 532).

Reorganizada dessa maneira, essa tipologia consegue recobrir o amplo espectro

\footnotetext{
${ }^{9}$ Um exemplo clássico é o som constante produzido pelo mar.
} 
de timbres com simplicidade e economia teórica na medida em que esclarece a confusa distribuição de timbres entre os termos subcontrários do quadrado de primeira geração. Apesar disso, um exame mais acurado dessa distribuição revela aí certos pontos frágeis. Uma leitura mais exigente poderá bem se perguntar - e não sem razão - que tipo de objetos sonoros corresponderiam aos termos simples do quadrado de primeira geração. De fato, seria pouco satisfatório construir uma categoria de timbres tomando como critério um único traço, tal como "ataque acentuado" ou "sustentação alongada". Uma maneira de sanar essa deficiência seria conjugar ambas as grandezas em um quadrado semiótico simples, aos moldes do que faz Greimas (1983b, p. 79-101; 2012 [1979] , p. 25-26, 124, 134-136, 172-173, 184-186 314-316, 372-374, 406) com as modalidades (cf. Figura 3.3). Apesar de sua adequação aparentemente idêntica, essa solução propicia uma descrição mais simples e, por isso, goza de maior elegância teórica.

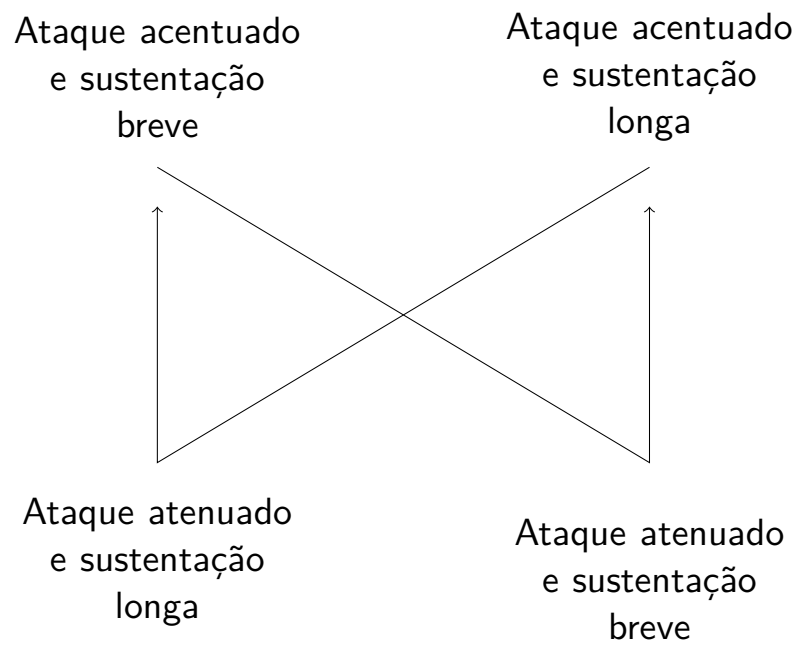

Figura 3.3: Quadrado semiótico de primeira geração articulando ataque e extinção do som. Fonte: elaboração própria com base em Greimas (1983b,p. 79-101).

Mais do que mero capricho conceitual, o esforço em reorganizar essa tipologia visa, acima de tudo, tornar explícita a articulação dos componentes temporalizantes do timbre. Apesar de sua maior simplicidade com relação à sua versão anterior, essa formulação comporta ainda certos pontos questionáveis, especialmente no que concerne a seu percurso sintáxico. Esse motivo nos leva a crer que é possível obter uma organização ainda mais enxuta mantendo o mesmo grau de adequação descritiva, como advogaremos a seguir. 


\subsection{Aspectualizando o envelope sonoro tímbrico}

\subsubsection{Andamento e aspectualidade do timbre}

O modelo discutido aqui propõe uma descrição morfológica dos timbres baseada em duas variáveis: o ataque e a sustentação do som. Tais critérios remetem à já consagrada divisão do envelope sonoro, proposta por Helmholtz no final do século XIX, em três fases de caráter essencialmente temporal: ataque (attack), regime estacionário (sustain) e extinção (release) (cf. Menezes, 2003 , p. 31). A inevitável tentação de homologar diretamente essas diferentes fases do devir sonoro aos aspectos incoativo, durativo (ou cursivo) e terminativo conforme empregados na semiótica discursiva (Greimas \& Courtés, 2012 [1979], p. 40) não deve ser aceita sem as devidas ressalvas.

Em um primeiro momento, duas correspondências parecem evidentes. De um lado, as percussões sem sustentação seriam caracterizadas pelo aspecto pontual, subsumindo os traços incoativo e terminativo. De outro lado, o aspecto durativo/cursivo corresponderia aos timbres de sustentação alongada e sem ataque pronunciado. Posta dessa forma, a distinção entre timbres cursivos/durativos e pontuais poderia ser equiparada à oposição entre limiares e limites conforme trabalhada por Zilberberg (1991).

Apesar de promissora à primeira vista, essa equiparação não é isenta de complicações, pois a distinção entre aspectos durativo e terminativo aplicados ao timbre é menos clara. Analisando o papel da evolução temporal do espectro dinâmico na constituição dos timbres, Menezes (2003) observa que não é razoável falar em transientes de sustentação, mas apenas em transientes de ataque e de extinção (2003, p. 220-223). Tais observações no campo da acústica podem ser corroboradas do ponto de vista semiótico. De fato, tudo o que sucede o momento incoativo constituído pelo ataque sonoro pode ser considerado já a sua terminação - ou ainda, em termos mais corriqueiros, o início de seu fim. ${ }^{10}$

Sendo assim, aquilo que chamaríamos de aspecto terminativo do timbre seria interpretado antes como uma extinção acelerada. Por sua vez, o efeito de sentido de duratividade manifestado em superfície resulta, na verdade, de uma extinção desacelerada. No limite, a extrema desaceleração da terminatividade geraria aqui o efeito de duração eterna. ${ }^{11}$

Seguindo a mesma linha de raciocínio, é possível também vislumbrar os efeitos do andamento predicando a fase de ataque sonoro. Sendo assim, aceleração e desaceleração

\footnotetext{
10 Sobre a comparação dessa proposta com o modelo de silabação de Saussure, conferir p. 80 abaixo.

11 Semelhante efeito de eternização resultante de um alentecimento extremo está por trás da cifra aspectual da personagem Nenha do conto "Nenhum, nenhuma" de Guimarães Rosa (Tatit, 2009, p. 409-411), em conformidade com Zilberberg $(2011 b$,p. 71) quando diz: "[...] : quanto mais elevada é a velocidade, menos longa é a duração - o ser, nesse caso, seria apenas um efeito da extrema lentidão".
} 
da incoatividade resultariam, respectivamente, em um ataque abrupto (percutido) e um ataque suave, como ocorre mais tipicamente com aerofones (sopros, órgãos de tubo, instrumentos de foles etc.) mas também com o ruído branco (cf. tabela 3.1).

\begin{tabular}{rll}
\hline Ataque $\downarrow$ Extinção $\rightarrow$ & Acelerado & Desacelerado \\
\hline Acelerado & agogôo, conga, etc. & sinos, pianos, vibrafones etc. \\
Desacelerado & sons abafados & aerofones, ruído branco \\
\hline
\end{tabular}

Tabela 3.1: Declinação do andamento pelas grandezas de ataque e extinção do som

Lançando mão das ferramentas semióticas para a temporalização do timbre, essa proposta vai ao encontro da distinção feita, em campo acústico, entre ataques rígidos, de duração entre 3 e 10 milissegundos, ataques de rigidez percebida variável (durando entre 10 e 50 milissegundos) e ataques ditos imperceptíveis que, durando mais do que 50 milissegundos, tendem a se fundir com a fase estacionária do som (Menezes, 2003, p. 179). Independentemente dos valores obtidos por meio da mensuração laboratorial, importa-nos aqui acima de tudo concluir que a distinção entre ataques abrupto e suave é determinada em função de grandezas temporais, conforme já apontado aliás também por Menezes (2003): "A natureza desse tipo de evolução inicial do som depende de seu ataque. Ataques mais abruptos ou duros atingem mais rapidamente a amplitude máxima do som, ataques mais brandos ou moles precisam de mais tempo para isto." (2003, p. 29).

Reduzindo de três para dois os momentos constitutivos da percepção de timbres, a intervenção do andamento sobre a fase incoativa e terminativa cria o efeito de elasticidade temporal manifestado em superfície. Por permitir um tratamento gradualizado, essa maneira de temporalizar o timbre torna a descrição mais refinada por ser mais fiel à nossa experiência empírica como ouvintes. Categorizações estáticas levantariam inevitavelmente a questão das nuanças implicadas em cada categoria: como conceber diferentes graus de incoatividade, de terminatividade ou - caso ainda mais delicado - de duratividade?

Por esse motivo, a noção de aspecto propicia maior refinamento descritivo ao ser predicada pelo andamento. Assim, é possível cifrar nuanças graduais de aceleração ou desaceleração para cada timbre ou família de timbres e distinguir, por meio do andamento, os diferentes modos de ataque (beliscado, friccionado, percutido, etc.) e extinção (abafado, fade-out, etc.).

\subsubsection{Extrapolações da noção de aspecto}

Essa interpretação das fases do envelope sonoro em termos de aspectualidade e andamento só pode ser conduzida às custas de certas extrapolações conceituais. A essa altura, já se faz claro que o uso da noção de aspecto aplicado ao timbre ultrapassa 
os limites de sua conceptualização original como categoria verbal das línguas naturais para assumir o papel de modulador global de limites e limiares (Zilberberg, 1991). Não é demais relembrar com Zilberberg (2011a) que "[...] a semiótica, divergindo de suas escolhas iniciais, terminou por conceder ao aspecto um alcance extraordinário, muito além de sua aplicação ao processo" (2011a,p. 16).

No caso do timbre, é necessária ainda uma ressalva adicional. Importada do plano do conteúdo para o plano da expressão, a noção de aspecto se afasta das questões relacionadas à dissociação entre um actante narrador e um actante observador em narrativas verbais - associadas pelo próprio Greimas à aspectualização do discurso (Greimas \& Courtés, 2012 [1979] , p. 39-40). ${ }^{12}$ Trata-se, então, de aspectualização em um sentido mais alargado e, como notado por Zilberberg (2011a), com alcance mais amplo do que aquele previsto em sua concepção original.

Conduzido dessa forma, esse movimento de alargamento confere à aspectualização as feições do modelo silábico de Saussure (1991 [1916] ,p. 62-78), baseado em explosões e implosões. É interessante notar que, no pensamento de Saussure, a sílaba compreende também apenas duas fases componentes (e não três), sendo que o ponto vocálico já é considerado como parte do momento implosivo da sílaba (cf. Saussure, 1991 [1916], p. 70-71). Tal esquematização corresponde à síncopa da fase durativa que explanamos anteriormente (cf. p. 78) em favor de uma leitura em termos de sobremodalização do andamento. Guardadas as devidas proporções, pode-se afirmar que o modelo em construção aqui se assemelha portanto a um perfil de sílaba tímbrica.

\subsection{Precedentes do emprego da aspectualização a ele- mentos do Plano da Expressão}

Apesar do risco aí implicado, tal aplicação da aspectualidade a elementos do plano da expressão não chega a ser inédita nos estudos semióticos. Ao discutir os desdobramentos temporais implicados na experiência olfativa, Fontanille (2001) recorre ao que seria uma sintaxe aspectual da matéria:

Foi possível observar notadamente: (1) que o odor obedecia a uma sintaxe principalmente aspectual e genérica e que ela suspendia as distâncias espaciais e temporais; (2) que o sabor obedecia em contrapartida a uma sintaxe actorial (as redes de atores responsáveis por predicados gustativos),

\footnotetext{
12 Conforme registrado pelo argumentário do simpósio "A aspectualização em semiótica" realizado em Abril de 2017 por ocasião do X Congresso Internacional da Associação Brasileira de Linguística (ABRALIN). Cf. http://www.abralin.org/congresso2017/lista-simposios
} 
sob a condição de um alentecimento e de uma segmentação da sensação; por consequência, ela implica também uma sintaxe temporal e espacial analítica. (Fontanille, 2001,p. 95 , tradução nossa ${ }^{\mathrm{xxix}}$, grifos nossos)

Em seu trabalho sobre as sintaxes figurativas, Fontanille (1999) segmenta a sintagmática olfativa em três fases aspectuais (nascimento, degradação e decomposição) e mostra como elas se homologam à axiologização dos odores: cheiros desagradáveis são correlacionados ao fim de processo (tipicamente a putrefação e a deterioração) ao passo que cheiros agradáveis são associados à incoatividade, portando valores de frescor e vitalidade (Fontanille, 1999 , p. 25-27). Mais adiante, esse autor sumariza a aplicação da aspectualização aos dados sensoriais da seguinte forma:

Quanto à categorização pelas fases aspectuais de um processo, nós mostramos (1) que o processo aspectualizado é o do devir do ser vivo e (2) que a categorização aspectual do ser vivo domina todas as outras, notadamente no momento de identificação do odor. (Fontanille, 1999, p. 63, tradução $\left.\operatorname{nossa}^{\mathrm{xxx}}\right)$

De maneira semelhante, Parret (2006) põe em cena uma morfologia aspectualizada para analisar a experiência estésica da degustação do vinho e compará-la com a apreensão do timbre (referida pelo autor como "qualité de la voix"). Esse autor declara que não é possível descrever a percepção olfativa, gustativa e auditiva sem necessariamente introduzir morfologias temporais (Parret, 2006, p. 50). Tal abordagem de natureza sintáxica e temporalizada viabiliza a descrição semiótica (ainda que não totalizante) da experiência gustativa e, portanto, sua maior inteligibilidade:

Se há sintaxe, é porque a degustação do vinho é linear, se desenvolve em uma temporalidade fortemente aspectualizada. Os predicados se organizam em torno de três aspectos semióticos canônicos: a incoatividade, a duratividade e a terminatividade, que Bordron reintitula: ataque, evolução e final. (Parret, 2006 , p. 51, tradução nossa ${ }^{\text {xxxi }}$ )

Em que pesem as diferenças entre a apreensão estésica do vinho e da voz sublinhadas por Parret (2006), interessa aqui sobretudo enfatizar que, longe de ser uma inovação proposta pelo presente estudo, a aplicação do conceito de aspectualização a dados de sensorialidade já não é inédita nas análises semióticas. 


\subsection{Sobre a necessidade e a insuficiência do trata- mento aspectual}

O exame do timbre sob as lentes da aspectualidade trouxe à luz estruturas invariantes subjacentes à sua multiplicidade de manifestações, caóticas apenas em aparência. Em contrapartida, certas insuficiências da abordagem temporalizante aqui proposta foram se revelando ao longo dessa investigação. O percurso traçado mostrou que, contrariando o senso comum sobre a questão, o universo dos timbres não é um contínuo magmático e indivisível. O procedimento de classificação conforme a natureza de seu ataque e de sua sustentação - que, como argumentamos, pode ser entendido como o retardamento da extinção do som - aponta já uma direção para esclarecer semioticamente os critérios de seleção e combinação de timbres em textos cancionais e musicais. Embora esse encaminhamento não contemple ainda outras questões prementes relativas à produção de sentido do timbre (notadamente a iconização), ele revela já diretrizes fundamentais gerais para o tratamento semiótico do timbre para além de seu suposto caráter inefável.

Observar a morfologia temporal do timbre sob lentes semióticas permite também esclarecer certas imprecisões criadas pelas tipologias de instrumentos musicais tornadas mais canônicas. A título de exemplo, é proveitoso olhar para o caso de instrumentos como bandolim e cavaquinho. Tradicionalmente classificáveis como "cordas beliscadas", tais instrumentos demonstram, em comparação com seus congêneres como o violão e a harpa, uma duração marcadamente abreviada que os aproximaria das percussões. Para além da categorização discreta, o tratamento temporalizante proposto aqui permite discriminar tais nuanças com maior economia teórica na medida em que dispensa a criação de novas subcategorias ou novos dispositivos conceituais para tal.

Além disso, o tratamento aspectualizante dispensado ao timbre se mostra compatível com o ferramental teórico herdado de Zilberberg por Tatit (1997, 2004b, 2007) sem, no entanto, forçar homologias unívocas, porém tendencialmente artificiosas, com os regimes de tematização e passionalização cunhados pelo semioticista brasileiro (cf. Tatit, 2002; Tatit, 1997, p. 101-160). Ao manejar os mesmos instrumentos conceituais de base, tal abordagem atende ao princípio de economia teórica. Outro ganho analítico da aplicação da aspectualidade ao timbre é o caráter sintaticizante dessa abordagem, reconhecível tanto na sintaxe elementar do quadrado semiótico quanto no protomodelo de "sílaba tímbrica" esboçado aqui. A dissecção de uma sintagmática do timbre se revela mais proveitosa do que a mera enumeração em inventários, de natureza forçosamente lacunar e não-exaustiva. ${ }^{13}$

13 Hjelmslev (2006 [1943], p. 123-125) nota o caráter não-sistemático desse modo de proceder ao discutir o método de "extração" de variáveis e variantes na análise de semióticas conotativas. Vale a pena 
No caso particular do timbre, a construção de paradigmas resvala com frequência na problemática da fonte sonora. Uma das vantagens de uma descrição em termos aspectuais é desvencilhar parcialmente o timbre dessa ancoragem à macrossemiótica do mundo natural. Nessa etapa da descrição, a figurativização de uma entidade do mundo é deixada em segundo plano em favor do estilo aspectual do timbre, definido pela declinação do andamento com as fases aspectuais de ataque e extinção.

Do mesmo modo, o caráter suficientemente abstrato dessa abordagem permite ainda contemplar fenômenos da ordem do sensível que não podem ser explicados de maneira satisfatória pelo encadeamento linear de transformações juntivas entre sujeitos e objetos, conforme trabalhado pela sintaxe narrativa na semiótica greimasiana (Greimas \& Courtés, 2012 [1979], p. 475-477). Colocada, assim, em patamar de maior abstração, tudo leva a crer que a determinação do perfil aspectual do timbre corresponde a um primeiro nível de descrição, que, guardadas as devidas proporções, é comparável ao nicho ocupado pelo nível fundamental no modelo do percurso gerativo (Greimas \& Courtés, 2012 [1979] , p. 232-235). O fato de que a cifra aspectual se manifesta de maneira menos explícita na superfície textual de peças musicais e canções não contradiz tal constatação; ao contrário, corrobora sua pertinência aos níveis mais abstratos de descrição do timbre.

Admitir, portanto, a aspectualidade como primeiro nível mais geral e mais abstrato de descrição do timbre se revela então como o principal ganho e o principal limite da abordagem aqui proposta. Assim como ocorre com toda categorização de maior grau de generalidade, as tramas grossas dessa malha tecida aqui deixa escapar ainda outras características não negligenciáveis do timbre e, assim, acaba por criar classes heterogêneas. Se é verdade que o tratamento aspectual permite fazer uma primeira limpeza de terreno do universo de timbres e estabelecer balizas para sua descrição, é preciso reconhecer também que, cedo ou tarde, o semioticista deverá se ocupar dos dados residuais não contemplados por tal grade de leitura.

A respeito da heterogeneidade de classes amplas, as próximas investigações deverão procurar critérios para distinguir timbres de mesma cifra aspectual. Um caso claro é o termo complexo $(\mathrm{s} 1+\mathrm{s} 2)$ do quadrado de segunda geração deduzido no presente trabalho (cf. Figura 3.2, p. 76). Da maneira como apresentada nesse modelo, tal categoria abrange timbres consabidamente distintos entre si, como as cordas friccionadas (violino, viola, violoncelo, contrabaixo, rabeca etc.), os diversos tipos de cordas beliscadas (violão, bandolim, banjo, cavaquinho, harpa, shamisen entre tantos outros) e as assim chamadas

relembrar também, de passagem, que essa foi justamente a ruptura proposta em Greimas \& Fontanille (1993) a respeito do estudo das paixões: não criar apenas mais uma taxionomia dentre as inúmeras já existentes, mas sim analisar os dispositivos passionais em sua sintagmática interna. Conferir também as observações críticas de Lindenberg Lemos (2015,p. 19-58) a respeito do procedimento de catalogação em inventários. 
percussões de altura definida (prototipicamente o piano, mas também o vibrafone, o xilofone, a celesta, a Glassharmonika entre outros).

Da mesma maneira, os diversos tipos de aerofones precisam ser distintos semioticamente entre si, embora portem todos eles o mesmo perfil aspectual. Tendo em mãos os instrumentos conceituais que mobilizamos aqui, é razoável reunir sob a mesma categoria aspectual flautas, ocarinas, clarinetes, saxofones, fagotes, trombones, trompas, órgãos de tubo, gaitas de foles, sanfonas etc.; mas seria razoável dar-se por satisfeito com a identidade profunda de todos esses timbres, inegavelmente distinguíveis em nossa experiência empírica como ouvintes? Colocando a questão em outras palavras: a coerência interna de uma categorização de tal amplitude poderá saciar o apetite do semioticista por uma descrição adequada de seu mundo circundante?

Se retomamos em primeiro lugar o exemplo do termo complexo, é porque ele parece reunir casos problemáticos de maneira mais facilmente visível. Nessa categoria, é premente desenvolver ainda outros subcritérios para distinguir timbres aos quais não se pode atribuir indubitavelmente nem uma aspectualidade pontual, nem uma aspectualidade cursiva. Questionamentos como esse levam à conclusão de que restam ainda outros componentes responsáveis pela distinção de timbres para além de sua temporalização.

A descrição aspectual encontra seus limites quando confrontada com a distinção e reconhecimento de diferentes nuanças de um mesmo tipo tímbrico. Parret (2006) faz referência à problemática da voz humana, mas o questionamento poderia ser igualmente colocado para a distinção entre dois violões, duas flautas, dois violinos etc. Propondo a um ouvinte qualquer identificar um instrumento específico dentre dois de mesma classe, a seguinte pergunta se coloca: a quais caracteres semióticos recorrerá esse sujeito além do perfil aspectual de seu envelope sonoro?

Outro viés que evidencia a necessidade de refinamento da descrição do timbre é a problemática da permutabilidade dos timbres em uma instrumentação dada. ${ }^{14}$ Seria ainda insuficiente de nossa parte encerrar essas reflexões sem mencionar uma última lacuna deixada em aberto pelo tratamento aspectual proposto aqui, a saber, a questão da miscibilidade de timbres. Tomando como base exclusivamente a categorização aqui elaborada, pode-se presumir que dois timbres pertencentes à mesma categoria sejam livremente permutáveis. Contrariando essa expectativa, dados empíricos apontam, no entanto, para a interferência de um subconjunto de restrições regulando a mistura de timbres, mesmo quando apresentam a mesma cifra aspectual subjacente. Essa problemática pode ser flagrada de maneira explícita no seguinte depoimento do compositor e arranjador Radamés Gnatalli:

\footnotetext{
${ }^{14}$ Fenômeno alcunhado "alotimbria" em Coelho (2004).
} 
Até aquele tempo, música brasileira só se tocava com regional: dois violões, cavaquinho, pandeiro e flauta ou bandolim. Quando eu comecei a fazer os arranjos para o Orlando Silva, usava violinos nas músicas românticas e metais nos sambões. Aí começaram a reclamar, até por cartas, dizendo que eu estava deturpando o samba com os violinos e que música brasileira só podia ter violão e cavaquinho. (Gnatalli, 1979 , p. $35)$

Apesar de idênticos com relação a sua morfologia temporal, os timbres mencionados não eram tomados por equivalentes pela norma estética vigente à época. Isso atesta que não apenas a morfologia interna do timbre determina sua seleção, mas também sua compatibilização com os demais timbres co-ocorrentes. ${ }^{15}$ Em que pese a amplitude de seu alcance, essa visada temporalizante deixa ainda resíduos que esperam pacientemente receber do semioticista um tratamento adequado em camadas ulteriores de análise. A ele, nada mais resta agora do que elaborar os artefatos conceituais adequados para tal operação de risco.

\section{Citações traduzidas no original}

xxix On a pu remarquer notamment : (1) que l'odeur obéissait à une syntaxe principalement aspectuelle et générique, et qu'elle suspendait les distances spatiales et temporelles : (2) que la saveur obéissait en revanche à une syntaxe actorielle (les réseaux des acteurs responsables des prédicats gustatifs), sous condition d'un ralentissement et d'un découpage de la sensation ; par conséquent, elle implique aussi une syntaxe temporelle et spatiale analytique.

${ }^{\mathrm{xxx}} \mathrm{Du}$ coté de la catégorisation par les phases aspectuelles d'un procès, nous avons montré (1) que le procès aspectualisé est celui du devenir du vivant et (2) que la catégorisation aspectuelle du vivant domine toutes les autres, notamment au moment de l'identification de l'odeur.

xxxi S'il y a syntaxe, c'est que la dégustation du vin est 'linéaire', se déploie dans une temporalité fortement aspectualisée. Les prédicats s'organisent autour des trois 'aspects sémiotiques' canoniques: l'inchoativité, la durativité et la terminativité, que Bordron réintitule: attaque, évolution, finale.

\footnotetext{
${ }^{15}$ Cf. Cap. 4.
} 
Capítulo 4

TRIAGENS E MISTURAS TIMBRÍstiCAS 


\section{Capítulo 4}

\section{Triagens e misturas tímbricas}

\subsection{Descrições morfologizantes e sintaticizantes de timbre}

Cada qual em seu campo de atuação, incontáveis análises do timbre procuraram segmentá-lo e limiarizá-lo em algum tipo de morfologia temporal interna. Hoje tidos indiscutivelmente como divisores de águas, trabalhos como o Traité des objets musicaux (Tratado dos objetos musicais) de Pierre Schaeffer (1966) e o Die Lehre von den Tonempfindungen als physiologische Gründe für die Theorie der Musik (Teoria das sensações sonoras como base fisiológica para a teoria da música) de Hermann von Helmholtz (1981 [1863]) contribuíram para consolidar tal abordagem morfologizante. A despeito dos notáveis avanços proporcionados por tais investigações, tal modo de proceder não é isento de questionamentos sobre seus limites.

Uma categorização de timbres construída exclusivamente em função das fases de ataque, sustentação e extinção está sujeita a resvalar em generalizações que contrariam nosso senso de adequação aos objetos empíricos. Mesmo quem não se declara musicista reconhece as deficiências de um modelo que agrupa, por exemplo, pandeiro, atabaque e cavaquinho sob um mesmo rótulo apenas devido ao seu caráter percussivo. ${ }^{1}$ É igualmente insatisfatório arregimentar acordeão, órgão e flauta sob a mesma categoria apenas por partilhar o mesmo perfil temporal-aspectual, a saber, ataque desacelerado e sustentação sonora alongada.

Embora não seja falsa em sentido estrito, tal tipologia carece de fidelidade descritiva aos objetos por criar categorias heterogêneas baseadas unicamente na morfologia temporal. Complementando essa abordagem, pode-se conjugar uma observação de outro ângulo que contemple, ao lado da morfologia interna do timbre, também suas circunjacên-

\footnotetext{
${ }^{1}$ Cf. Capítulo 3, em especial p. 82 ss.
} 
cias sonoras. Antes de mergulhar na aparelhagem conceitual semiótica propriamente dita e na sua aplicação na análise do timbre, convém recuar alguns passos para delinear os grandes traços dessa abordagem e justificar o recurso a ela.

\subsubsection{Dois modos de caracterizar um objeto: intra- e inter-}

Em estudo sobre a questão da interface entre objetos, Zinna (2005) distingue duas maneiras de caracterizar um objeto dado. A primeira delas consiste em decompô-lo em suas partes constituintes. Resgatando o pensamento de René Thom, Zinna (2005) aponta que é imperativo das ciências, em um dado estado de desenvolvimento, construir famílias de objetos classificando-os por sua morfologia (2005,p. 162). Na sequência, o autor relembra que esse método pautou em grande medida a classificação das "coisas minerais" pela geologia, das "coisas vegetais" pela botânica e das "coisas animais" pela zoologia. A segunda delas consiste em observar o objeto em suas interfaces objeto-sujeito e objeto-objeto (Zinna, 2005 ,p. 174 ss.).

No que diz respeito aos objetos sonoros, interessa sobretudo tirar proveito da noção de interface como alternativa à descrição de caráter morfologizante. Essa oposição apresentada em Zinna (2005) pode ser generalizada nos termos mais abstratos possíveis, tratando essas duas abordagens respectivamente como descrições de tipo "intra-" e de tipo "inter-". Não havendo em princípio nenhuma predeterminação imperativa, a opção por esses termos se dá pela conveniência dos prefixos disponíveis na língua.

Sendo assim, pode ser considerada uma descrição de tipo "intra-" toda e qualquer análise que decompõe um todo em suas partes constituintes. Grosso modo, todo procedimento de caráter morfológico (no sentido lato desse termo) põe em prática o modo "intra-". Tal foi a abordagem que levou os botânicos de outrora a descrever os vegetais segmentando-os em raiz, tronco, galhos, folhas, flores e frutos. É também pela mesma lógica que veio à luz a tradicional divisão da anatomia humana em cabeça, tronco e membros (superiores e inferiores). Para retornar ao domínio das ciências da linguagem, não é diferente o modo de proceder de semanticistas e foneticistas quando propuseram uma análise componencial das unidades mínimas de som e de sentido em traços distintivos. Virtualmente, essa lista de exemplos poderia se estender ao infinito. Conscientes das peculiaridades de cada campo particular, basta apenas apontar tal operação de divisão, de decomposição e de desmembramento de um todo em suas partes como o grande denominador comum desse procedimento de tipo "intra-".

Essa abordagem se deixa complementar por uma descrição de tipo "inter-". Opera no modo "inter-" toda análise que centra foco sobre as relações de um objeto com sua circunvizinhança e com seus congêneres. Segundo esse modo de proceder, um objeto se deixa descrever menos por sua constituição formal interna do que pela sua função em 
determinado contexto ou pelo seu modo de interação com outros elementos.

Esse tratamento "inter-" se revela especialmente proveitoso naqueles casos em que os objetos observados têm características superficiais de difícil discretização. Tal abordagem é comparável à discussão entabulada em Groupe $\mu$ (2015,p. 156) quando relembra que as substâncias químicas podem ser definidas em função das reações que desencadeiam. Ainda que pareça discrepante a uma reflexão semiótica, tal caso hipotético não é em nada diferente do problema da homofonia e da homonímia no âmbito do léxico das línguas naturais. As diferenças subjacentes a duas palavras idênticas em sua cobertura fonética podem ser reveladas observando seus contextos sintáticos e os termos com os quais elas co-ocorrem com mais frequência.

É assim que se pode resolver a homofonia, como ocorre com o termo "peça" em português brasileiro. A depender de seu entorno sintático, ele se revela ora como substantivo (pedaço ou parte de algo), ora como forma conjugada do verbo "pedir" no modo subjuntivo ("que eu/ele peça"). O mesmo procedimento se aplica também a termos homônimos. A título de exemplo, o termo "banco" em português brasileiro denota ora "instituição financeira", ora "peça de mobiliário" a depender de seus termos co-ocorrentes. ${ }^{2}$ Assim sendo, a expressão "banco privado" certamente evocará a primeira acepção, ao passo que a segunda será mais provável em expressões como "banco metálico" ou "banco recém-pintado". Note-se que, em um e outro caso, é a observação das adjacências do termo que permite a desambiguação. Certamente existem intersecções entre termos homônimos e nem todos os contextos conseguem discriminá-los univocamente (cf. Polguère, 2018, p. 200-201). ${ }^{3}$ Mais do que esgotar todas as possibilidades lógicas de tal raciocínio, interessa aqui antes de tudo demonstrar a operacionalidade daquilo que vem sendo designado como abordagem "inter-".

É proveitoso ainda sublinhar que o prefixo "inter-" pressupõe certa equanimidade dos termos postos em relação. Assim, o adjetivo "internacional" se refere à qualidade de algo "entre nações". Da mesma forma, é "intertextual" tudo aquilo que se dá "entre textos", assim como um estudo "interdisciplinar" deve se colocar forçosamente "entre disciplinas". 4 A constância do substantivo plural é prova de que os elementos postos em relação "inter-" são sempre, de alguma forma, congêneres e equiparáveis.

Aparentemente alheias a uma investigação semiótica, tais considerações devem chamar a atenção para uma forma de raciocínio eminentemente semiótica, segundo a qual a relação prevalece sobre os termos (Hjelmslev, 2006 [1943], p. 28-29). Por sua vez,

\footnotetext{
${ }^{2}$ Esse fenômeno linguístico é denominado colocação. Cf. Dubois (2011 [1973] , p. 116); Crystal (1988,p. $51)$.

${ }^{3}$ No exemplo em questão, uma sentença como "o banco quebrou" configura um exemplo de ambiguidade pluriisotópica irresolúvel.

${ }^{4}$ Uma interessante reflexão sobre o caráter "inter-" da interdisciplinaridade partindo da etimologia do prefixo pode ser consultado em Fiorin (2008b).
} 
essa premissa se põe em continuidade com o pensamento de Ferdinand de Saussure (1991 [1916] , p. 139 ss.), segundo a qual uma dada unidade do sistema linguístico só pode ser definida negativamente e por oposição às demais. Essa primazia da relação imprimirá sua marca por toda parte no projeto teórico da semiótica greimasiana.

\subsubsection{As relações na semiótica}

\section{Estruturalismo clássico e o desafio do léxico}

Descrever semioticamente o timbre observando suas relações mútuas pode soar uma proposta pouco original àqueles mais familiarizados com o conceito de valor linguístico de Saussure (1991 [1916] , p. 130-141). Nos textos do fundador da linguística moderna, já se encontram os fundamentos da abordagem provisoriamente alcunhada aqui como "inter-". Ao comentar sobre a determinação do significado dos lexemas de uma língua, o autor assim afirma: "Para esgotar o que é contido em 'espírito', por oposição a 'alma' ou ao 'pensamento', ou o que é contido em 'ir' por oposição a 'marchar', 'passar', 'caminhar', 'se transportar', 'vir' ou 'ficar', uma vida humana poderia, sem exagero, se passar.' (Saussure, 2004 , p. 71).

$\mathrm{Na}$ passagem acima, pode-se entrever como pano de fundo a noção saussuriana de valor, segundo a qual significado e significante se deixam analisar não por propriedades internas apriorísticas, mas sim por relações diferenciais contraídas dentro do sistema. Isso implica que o papel desempenhado por um conceito ou uma imagem acústica é dinâmico, mutável e pode assumir diferentes feições conforme a reorganização global do sistema no qual se insere. Nas palavras do próprio Saussure:

Tudo o que precede equivale a dizer que na língua só existem diferenças. [...] O que haja de ideia ou de matéria fônica num signo importa menos do que o que existe ao redor dele nos outros signos. A prova disso é que o valor de um termo pode modificar-se sem que se lhe toque quer no sentido quer nos sons, unicamente pelo fato de um termo vizinho ter sofrido uma modificação. (Saussure, 1991 [1916] ,p. 139)

Na mesma discussão sobre o caráter negativo e opositivo do valor linguístico, o fundador da linguística moderna assim pontua: "No interior de uma mesma língua, todas as palavras que exprimem ideias vizinhas se limitam reciprocamente: sinônimos como recear, temer, ter medo só têm valor próprio pela oposição; [...]. Assim, o valor de qualquer termo que seja está determinado por aquilo que o rodeia; [...]" (Saussure, 1991 [1916], p. 134-135). Indo na mesma direção, também Hjelmslev (1991) notou as dificuldades impostas pela descrição do vocabulário. Refletindo sobre as condições de 
construção de uma semântica estrutural, esse linguista reconhece no vocabulário um "campo de aventura" e um "terreno de jogo" e, em seguida, pontua os desafios de avançar nesse território de pesquisa:

Em oposição aos fonemas (em sentido amplo) (e aos grafemas, etc.), do mesmo modo que aos morfemas, os elementos do vocabulário, os vocábulos ou palavras têm em particular a circunstância de ser numerosos, talvez mesmo em número em princípio ilimitado e incalculável. Mais: o vocabulário é instável, muda constantemente, num estado de língua há um vaivém incessante de novas palavras que se forjam à vontade e segundo as necessidades, assim como palavras antigas que caem em desuso e desaparecem.(Hjelmslev, 1991, p. 113).

O embaraço apontado por esses linguistas no infindável trabalho de descrever um por um os vocábulos das línguas naturais pode ser facilmente transposto para o estudo dos timbres. Assim como ocorre com o léxico das línguas naturais, o valor do timbre se determina negativamente pela oposição que ele contrai com os demais. Descrever individualmente cada timbre existente no mundo é um trabalho de Sísifo com resultados de confiabilidade questionável.

\section{Semiótica greimasiana: do léxico ao discurso}

Semelhante motivo levou A. J. Greimas a abandonar os métodos da lexicografia tradicional para partir em busca de um projeto de semântica capaz de desvelar, sob as unidades lexicais, as estruturas elementares da significação. Em sua tese de doutoramento subsidiária, Greimas (2000 [1948]) empregou os métodos da lexicologia social preconizada por G. Matoré ${ }^{5}$ na análise textos sobre a moda francesa de 1830. Já àquela altura, Greimas buscava compreender o vestuário não como um inventário contingencial de vestimentas, mas sim como um sistema articulado. A esse respeito, o próprio autor afirmava:

Nosso estudo é consagrado à descrição das vestimentas do homem civilizado numa época determinada. Essas roupas não se apresentam como uma mistura acidental de elementos heterogêneos, mas antes como uma unidade orgânica em que as diversas partes da indumentária se harmonizam entre si. (Greimas, 2000 [1948], p. 19, apud Fiorin, 2017a,p. 16, grifos nossos).

Cerca de trinta e cinco anos depois, em testemunho prestado por ocasião do colóquio em Cerisy-la-Salle, o próprio Greimas avalia retrospectivamente sua passagem

\footnotetext{
${ }^{5}$ Sobre a lexicologia de Matoré, cf. Cambraia (2013)
} 
pela lexicologia e se pronuncia sobre sua insatisfação com um método focado mais nas unidades do que no sistema subjacente:

Foi porque vi, depois de um trabalho de cinco ou seis anos, que a lexicologia não levava a lugar algum - que as unidades /lexemas/ ou /signos/ não conduziam análise alguma, nem permitiam a estruturação, a compreensão global dos fenômenos - que entendi que é "sob" os signos que as coisas acontecem. Evidentemente, uma semiótica é um sistema de signos, mas sob a condição de ultrapassar esses signos e observar o que está subjacente a eles. (Arrivé; Coquet, 1987, p. 302-303, apud Hénault, 2017 , p. 8, tradução nossa xxxii)

A passagem acima esclarece como, para uma semiótica discursiva, interessam menos os signos do que os mecanismos discursivos que os engendram. O estudo da significação deve primar por seu caráter sintagmático e "explicar não as unidades lexicais particulares, mas sim a produção e a interpretação do discurso" (Greimas \& Courtés, 2012 [1979], p. 434, verbete "semântica"). Assim como o aporte teórico proposto por Greimas "busca estabelecer o sistema semântico que está na base da organização de um discurso" (Fiorin, 2017 a,p. 17), a presente investigação não visa pormenorizar à exaustão a identidade de timbres individuais, mas sim explicitar seu sistema de organização subjacente, reconhecível através de suas regras combinatórias tácitas.

$\mathrm{Na}$ forma do quadrado semiótico proposto por Greimas, esse sistema subjacente de organização trouxe inovações ao propor o encadeamento sintagmático de grandezas semânticas abstratas. As oposições míticas "vida vs. morte" e "natureza vs. cultura" foram articuladas em eixos semânticos construídos por meio de relações de contrariedade, contraditoriedade e implicação (Greimas, 1975b ,p. 110-216). O caráter sintaticizante dessas operações permitiu à semiótica greimasiana operacionalizar os achados dos estudos de Lévi-Strauss e generalizá-los para além do universo das narrativas míticas.

Semelhante guinada rumo às relações também possibilitou Greimas se apropriar dos estudos de Propp (1984) acerca da estrutura dos contos populares maravilhosos russos e ampliar seu rendimento analítico. Em sua Morfologia do conto maravilhoso, Propp demonstrava já um raciocínio linearizante na sua maneira de conceber a seleção e o encadeamento das diversas funções narrativas, pois havia entre elas restrições obrigatórias de antecedência e consequência. Sendo assim, a "traição" deveria necessariamente ocorrer após o "pacto" - mas nunca o inverso. Ampliando o poder de generalização desse modelo nas etapas do percurso narrativo canônico e nos actantes, Greimas postula que sujeito e objeto se interdefinem unicamente pela relação contraída, que pode ser ora contratual, ora polêmica (cf. Greimas, 1975b, p. 144-170). ${ }^{6}$ A contratualidade ou a polêmica se instauram

\footnotetext{
${ }^{6}$ As diversas possibilidades combinatórias entre actantes e estruturas narrativas gestados ao longo dos
} 
sobre o pano de fundo de uma relação, que permanece como denominador comum. ${ }^{7}$

\section{Da narratividade ao tratamento da matéria}

Mesmo em domínios menos antropomórficos, as relações contratuais e polêmicas se deixam observar, como demonstrado em "A sopa ao pesto e a construção de um objeto de valor" (Greimas, 1983b , p. 167-179). Nele, a análise mostra como as transformações efetuadas em uma receita culinária podem ser entendidas em termos de programas narrativos de separação e de mistura. Retomando explicitamente esse estudo, a semioticista Françoise Bastide (1987) aprofunda essas reflexões conferindo-lhes maior amplitude em seu seminal "Le traitement de la matière" (O tratamento da matéria).

Nele, a autora propõe uma semiotização das operações mais elementares aplicáveis à matéria (no sentido lato desse termo), tomando como corpus de análise receituários químicos e culinários. Nesse universo discursivo, os objetos se definem mais pelo seu percurso de construção do que por sua circulação "de mão em mão" entre sujeitos e antissujeitos, como habitualmente trabalhado pelo veio narrativo da semiótica greimasiana (Bastide, 1987 , p. 24-25). Isso se mostra proveitoso em grande medida na aplicação a universos discursivos de caráter menos marcadamente antropomórfico, o que contempla não só receitas culinárias e instruções laboratoriais farmacotécnicas, mas também arranjos orquestrais e instrumentais. ${ }^{8}$ Generalizando a concepção do programa narrativo básico como transformação de estados, a autora depreende um inventário fechado de operações elementares do tratamento da matéria, organizadas nas seguintes oposições hierarquizadas: abertura vs. fechamento, destruição vs. estruturação, mistura vs. triagem, expansão vs. concentração (Bastide, 1987, p. 22).

Sem intenção de reproduzir passo-a-passo todos os pormenores metodológicos e terminológicos do raciocínio da autora, basta por ora apenas sinalizar como as relações intertimbres podem ser mais claramente compreendidas por meio de operações elementares de combinação e de decomposição $(1987$, p. 8), bem como pela passagem do estado amorfo para um estado estruturado $(1987$, p. 11). Na acepção convocada pela autora, caracterizase como "estado amorfo" a dissolução das partes de uma matéria em outra, formando um todo indistinto. No universo culinário, esse estado é atestado quando ingredientes individuais perdem sua forma e gosto particulares para constituir uma composição amorfa (Bastide, 1987, p. 11). Para uma reflexão centrada sobre o timbre, o que interessa aqui é,

anos em diversos estudos da semiótica greimasiana se encontram sumarizadas em Hébert (2018 [2007] , p. 137-140).

${ }^{7}$ No âmbito das relações intersubjetais, essa ambivalência é evidenciada com clareza pelo neologismo de língua inglesa frenemy ("uma pessoa a quem se trata amigavelmente apesar de uma aversão ou rivalidade profunda". Cf. Oxford Dictionary (s/d)). No âmbito das relações sujeito-objeto, essa ambivalência se concretiza no pharmakón grego, a um só tempo veneno e remédio.

${ }^{8}$ Cf. adiante p. 99 ss. 
sobretudo, a ideia de dissolução plena de duas componentes para compor uma terceira, cuja aparência superficial mascara a composição que lhe deu origem. Mais adiante, definindo seu entendimento sobre o que ela trata como "estado discreto", a autora comenta: "Entretanto, o estado discreto parece, no conjunto do corpus, investido de um importante valor de uso: ele permite a mistura e a triagem, duas operações fundamentais no tratamento da matéria para fabricar objetos de valor." (Bastide, 1987,p. 12, grifos nossos, tradução nossa $\left.^{x x x i i i}\right)$. Não é sem propósito que destacamos aqui as noções de triagem e mistura. De fato, em nossa experiência sensorial, o estado "discreto" se deixa reconhecer nas situações em que divisamos as diferentes partes constituintes de um conjunto dado:

(...) um saco de grãos pode ser considerado como um objeto em um estado discreto e, entretanto, cada grão tem sua estrutura, e o saco propriamente dito pode ser estruturado: se ele for suficientemente chacoalhado, os grãos mais densos ficarão ao fundo, os mais leves em cima, formando uma estrutura em camadas. (Bastide, 1987,p. 12, tradução $\left.\operatorname{nossa}^{\text {xxxiv }}\right)$.

Logo na sequência, a autora prossegue apontando que um dado objeto pode ser considerado "simples" (quando constituído por partes idênticas ou indistinguíveis) ou composto (quando constituído por partes heterogêneas entre si) (Bastide, 1987, p. 13). Sendo assim, um objeto simples pode passar a composto por uma operação de união. Na direção inversa, um objeto composto pode vir a ser simples quando submetido a uma operação de seleção (cf. Bastide, 1987, p. 12). Resumindo em linhas bem gerais, tratase aqui de inventariar semioticamente as diversas transformações da matéria conforme percebidas pela experiência sensorial mundana, como observado pela introdução assinada por Greimas (Bastide, 1987, p. 5).

Mesmo não tendo completado ainda o panorama semiótico sobre as diferentes facetas do modo "inter-", gostaríamos de convidar o leitor a já refletir sobre como esses diferentes graus de homogeneidade podem ser transpostos para entender as combinações timbrísticas que compõem os arranjos orquestrais e instrumentais. Antes de passar para a aplicação prática dessas ideias à matéria sonora do timbre, convém apresentar ainda outros desenvolvimentos teóricos que proporcionarão maior operacionalidade e precisão à análise.

\section{Do tratamento da matéria à mestiçagem}

Por antecipar certas direções tomadas por estudos posteriores (Fontanille \& Zilberberg, 2001; Zilberberg, 2004, 2006a,b, 2011a,b), o trabalho de Bastide (1987) tem sido frequentemente considerado como um ensaio de semiótica tensiva avant la lettre. 
Em comentário avaliativo sobre suas próprias propostas apresentadas em "Condições semióticas da mestiçagem", (Zilberberg, 2004, p. 75) cita explicitamente as propostas de Bastide (1987) e Greimas (1983b) como precursores: "O que se está esboçando aqui é uma semiótica do afeto, um processamento analítico do afeto, comparável ao "processamento da matéria', abordado com êxito por F. Bastide e Greimas." (Zilberberg, 2004, p. 75)

Em franco diálogo com Bastide (1987), Zilberberg (2004) operacionaliza as ideias dessa autora convertendo em operações tensivas os processos de triagem e mistura por ela aventados. A título de lembrete, convém recapitular o lugar ocupado pela extensidade no esquematismo tensivo": "A constituição do sentido estaria situada na junção entre uma medida intensiva e um número extensivo. [...] A nosso ver, o número está para a extensidade assim como a medida está para a intensidade." (Zilberberg, 2004,p. 73). Segundo suas propostas, a extensidade concerne ao que é contável e à sua distribuição em classes.

\begin{tabular}{rllll}
\hline matriz & $\begin{array}{l}\text { sobrecontrário } \\
\text { átono (s1) }\end{array}$ & $\begin{array}{l}\text { subcontrário } \\
\text { átono (s2) }\end{array}$ & $\begin{array}{l}\text { subcontrário } \\
\text { tônico (s3) }\end{array}$ & $\begin{array}{l}\text { sobrecontrário } \\
\text { tônico (s4) }\end{array}$ \\
$\begin{array}{rlll}\text { Semântica intensiva } \\
\text { Sintaxe intensiva }\end{array}$ & $\begin{array}{l}\text { supremo } \\
\text { aumento }\end{array}$ & forte & fraco & $\begin{array}{l}\text { nulo } \\
\text { diminuição }\end{array}$ \\
\hline $\begin{array}{r}\text { Semântica extensiva } \\
\text { Sintaxe extensiva }\end{array}$ & triagem & raro & comum & $\begin{array}{l}\text { universal } \\
\text { mistura }\end{array}$ \\
\hline $\begin{array}{rlll}\text { Semântica juntiva } \\
\text { Sintaxe juntiva }\end{array}$ & $\begin{array}{l}\text { supreendente } \\
\text { concessão }\end{array}$ & inesperado & esperado & $\begin{array}{l}\text { necessário } \\
\text { implicação }\end{array}$ \\
\hline
\end{tabular}

Tabela 4.1: Sintaxe e semântica intensiva, extensiva e juntiva. Fonte: Traduzido e adaptado de Zilberberg (2011a,p. 66) em conformidade com as observações da nota de rodapé 13 à p. 50 acima.

O mesmo autor aponta ainda que as taxionomias e classificações, tão caras à antropologia - e também ao estudo semasiológico do léxico, acrescentaríamos por nossa conta - , podem ser concebidas como resultantes de operações recíprocas de triagens e misturas (Zilberberg, 2011b,p. 122, 210-214). Esse autor não deixa margem de dúvida quanto ao papel dessas operações no exercício de categorização das entidades do mundo:

No que tange à extensidade, é preciso avaliar, a partir das triagens e misturas toleradas ou interditadas, o grau de entrelaçamento ou de exclusividade que a grandeza admite: constituiria ela, por si só, uma classe, ou participaria 'amigavelmente' de outras classes? (Zilberberg, 2011b, p. 67-68)

\footnotetext{
${ }^{9}$ Ao leitor não-familiarizado, recomenda-se uma síntese didatizada dos fundamentos da semiótica tensiva conforme apresentada em Fiorin (2015).
} 
Toda a sintaxe extensiva desenvolvida por Zilberberg (2004) está apoiada sobre a reciprocidade interna dessas operações. Nas palavras desse semioticista, "[...] só se fazem distinções, de um lado, à custa de misturas, do outro. Referidas umas às outras, as classificações operam decretando ora a identidade dos contrários, ora a contrariedade dos idênticos." (Zilberberg, 2004,p. 74, grifos nossos).

Cristalizada em provérbios e expressões idiomáticas, a sabedoria popular revela um farto manancial de exemplos que sintetizam de forma mais transparente essa concatenação entre, de um lado, identidades e diferenças ${ }^{10}$ e, de outro lado, triagens e misturas. Num percurso rumo à generalização, proclama-se a identidade dos contrários. No fundo, é essa neutralização de particularidades que está por trás do ditado "À noite, todos os gatos são pardos". Esse mesmo gesto de indistinção faz o sujeito desiludido exclamar: "é tudo farinha do mesmo saco!" ou então "é tudo da mesma laia!". Aqui, toda diferença e individualidade é abstraída em nome de uma equivalência generalizada e levada ao extremo pelo quantificador totalizante ("tudo"). Disso decorre certa propensão à mistura indiscriminada em que tudo se equivale a tudo à revelia de suas singularidades. Valendo-se do raciocínio concessivo tão caro ao pensamento de Zilberberg (2004, 2011a), pode-se sintetizar essa lógica na seguinte fórmula: apesar de diferentes em aparência, os elementos devem ser tratados como iguais.

Ainda no mesmo universo dos cereais, a expressão "separar o joio do trigo" vai na direção diametralmente oposta na medida em que recomenda uma distinção mais refinada de elementos a princípio semelhantes. É o que se reconhece em expressões como "passarinhos e pardais, não são todos iguais". Não é outro o raciocínio por trás da inegável recusa à generalização presente em "cada cabeça, uma sentença", como se reafirmasse a necessidade de contemplar as idiossincrasias de cada caso. Diga-se de passagem, não é fortuito aqui o uso do quantificador individualizante "cada", especialmente se confrontado aos totalizantes ("tudo", "todos") atestados no cenário anterior. Assim, poderíamos mais uma vez recorrer à concessividade para sintetizar esse raciocínio invertendo a fórmula anterior: apesar de iguais em aparência, os elementos devem ser tratados como diferentes. Mais do que mero capricho estilístico, o quiasmo das fórmulas-síntese que propomos vem ecoar o espelhamento estrutural entre a triagem e a mistura conforme apontado em Zilberberg $(2004,2006 b, 2011 a, b)$. A esse respeito o autor afirma que “[...] o sujeito semiótico não pode evitar de triar misturas, visando a um valor de absoluto, e de misturar triagens, visando a um valor de universo." (Zilberberg, 2011b, p. 122). Na mesma direção, o autor pormenoriza esse raciocínio de forma menos lacônica. Em suas próprias próprias palavras:

\footnotetext{
${ }^{10}$ Cf. Cap. 2.
} 
[...] a dimensão da extensidade tem, como intervalo de referência, [concentrado vs. difuso], ou ainda [puro vs. impuro], isto é, justamente, miscigenado, misturado e, mediante catálise, misturado com... A sintaxe da extensidade operaria exclusivamente por triagens e misturas, de tal sorte que cada operação teria sempre a outra por objeto: a triagem recai sobre misturas que ela desfaz, na exata medida em que a mistura incide sobre as resultantes de triagens anteriores. (Zilberberg, 2004,p. 72)

Nessa passagem, é preciso ressaltar ainda como certa "memória" das operações anteriores (cf. Greimas \& Courtés, 2012 [1979]) de triagem e mistura se deixa entrever em suas marcas e vestígios. Partindo do raciocínio de que a extensidade corresponde à distribuição dinâmica de entidades em classes, o autor aponta que uma classe qualquer com [n] elementos está apta a "ganhar" elementos, passando a $[n+1]$, ou então a "perdêlos", passando assim a [n-1]. Para que sejam percebidos como tais, esses acréscimos e diminuições exigem como condição certa reminiscência do estágio anterior (Zilberberg, 2004 , p. 73).

As operações de triagem e mistura não estão isentas de apreciações valorativas e cada qual pode ser avaliada ora positiva, ora negativamente. Quando a triagem extrai grandezas tidas como positivas, trata-se de um processo de seleção. Na direção oposta, configura um processo de profanação a inclusão de grandezas indesejáveis. Invertendo a polaridade da operação, se essas mesmas grandezas negativas forem extraídas de um dado conjunto, estaremos então diante de um processo de expurgo, de depuração ou de eliminação. Como consequência, o acolhimento de grandezas positivas na categoria corresponderá a um processo de enriquecimento (cf. Tabela 4.2.).

\begin{tabular}{rll} 
operação $\downarrow$ axiologia $\rightarrow$ & MELHORAÇÃo & PEJORAÇÃo \\
\hline TRIAGEM & $\begin{array}{l}\text { seleção (extração de uma } \\
\text { grandeza boa) }\end{array}$ & $\begin{array}{l}\text { eliminação (extração de uma } \\
\text { grandeza má) }\end{array}$ \\
MISTURA & $\begin{array}{l}\text { enriquecimento (inclusão de } \\
\text { uma grandeza boa) }\end{array}$ & $\begin{array}{l}\text { profanação (inclusão de uma } \\
\text { grandeza má) }\end{array}$ \\
\hline
\end{tabular}

Tabela 4.2: Triagens e misturas e suas respectivas axiologias. Fonte: Zilberberg (2004, p. 89).

Delineadas essas quatro possibilidades, um olhar em recuo detecta aí facilmente o pareamento dos quadrantes em diagonal. Quando a triagem é positivamente valorizada, a mistura é vista como indesejável. Trata-se dos valores de absoluto (Zilberberg, 2011a, p. 7-45). É o que ocorre, por exemplo, com os regimes aristocráticos (Zilberberg, 2011a,2549), em que uma elite seleta, menos numerosa e positivamente valorizada se destaca sobre uma maioria negativamente valorizada. Esse regime semiótico subjaz também a panteões, 
cânones, comitês, conselhos de notáveis e a todo tipo de pequeno grupo de "poucos e bons".

Em contrapartida, quando a triagem é indesejável, a mistura se afigura como valor desejável. Nesse cenário, estamos no domínio dos valores de universo. Esses estão na base dos regimes democráticos (Zilberberg, 2011a ,25-49), em que a equanimidade da maioria é o bem último almejado. Ainda segundo Zilberberg (2011a), esse é o regime semiótico subjacente a movimentos como a revolução francesa, a declaração universal dos direitos do homem e a toda iniciativa de acolhimento "amplo, geral e irrestrito".

Uma das decorrências mais patentes dessa linha de raciocínio é a assimetria numérica posta em jogo nos valores de absoluto e de universo. Nos primeiros, a operação de triagem visa reduzir o conjunto o tanto quanto possível para nele reter apenas a mínima parcela necessária. Nos segundos, essa fração minoritária permanece alheia à ação da mistura, que vem maximizar a inclusão dos excluídos.

Entre triagem e mistura, há um espelhamento estrutural. Quando a triagem se eleva a seu máximo grau, a mistura é reduzida à nulidade: temos aí o estado denominado separação. No estado denominado fusão, invertem-se os valores: a triagem é anulada em favor da mistura plena. Interpolando esses limites extremos, os estágios intermediários resultam de relações de dominância relativa da triagem e da mistura e denominados respectivamente como contiguidade e mescla (Zilberberg, 2004, p. 76-77), conforme sintetizado em representação visual provisória aventada pelo próprio autor (cf. Figura 4.1). É proveitoso relembrar que triagem e mistura oferecem pontos de vista opostos e complementares de um mesmo processo, apenas permutando sua direcionalidade.

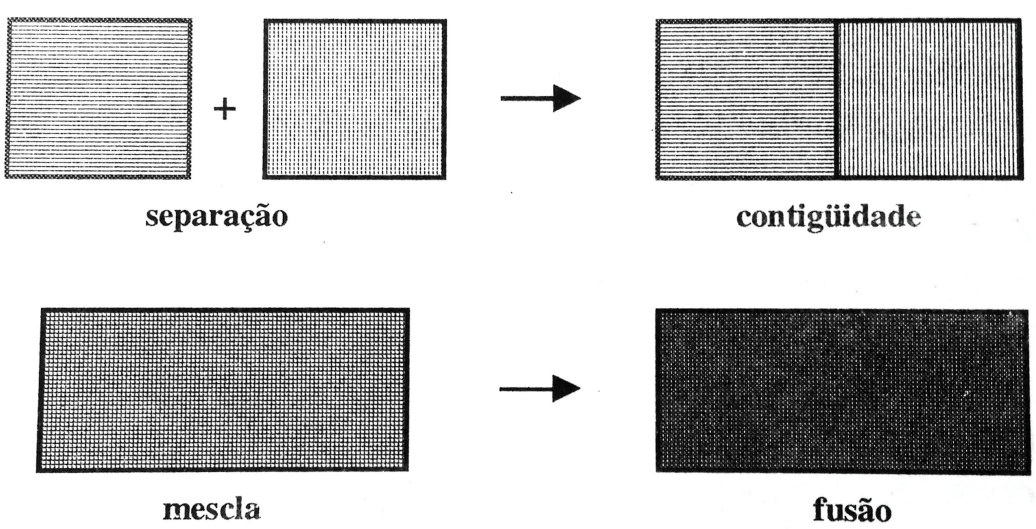

Figura 4.1: Representação visual dos estágios da sintaxe extensiva. Fonte: Zilberberg (2004,p. 76-77)

Nesse breve apanhado panorâmico, apresentamos em linhas gerais e de maneira sintetizada os fundamentos da sintaxe extensiva, uma das grandes dimensões do esquematismo tensivo (Zilberberg, 2004, 2006b, 2011a,b; Fontanille \& Zilberberg, 2001). A presente revisão conceitual atesta como a semiótica pode operacionalizar a descrição do 
timbre olhando para suas relações de tipo "inter-". ${ }^{11}$ Ao recorrer às operações de triagem e mistura, a análise das relações intertimbrísticas em termos tensivos possibilita resultados mais objetivos e comparáveis àqueles obtidos por aplicações desse mesmo aparato conceitual a outros objetos. Até o presente momento, viemos discorrendo sobre as operações de triagem e mistura em termos propositalmente abstratos, tais como "elementos", "itens", "grandezas" etc. De ora em diante, passaremos a explorar o rendimento analítico dessas noções aplicadas especificamente ao timbre.

\subsection{Sintaxe extensiva aplicada ao timbre: estágios de miscibilidade}

Em um domínio consabidamente refratário a oposições binárias, como é o caso do timbre, a preferência pelo conceito hjelmsleviano de dependência ostensivamente convocado por Zilberberg representa uma vantagem heurística: "Que não haja vínculo necessário entre os conceitos de diferença e de oposição, é o que demonstra a obra de Hjelmslev, que deliberadamente ignora o conceito de oposição, preferindo-lhe, de longe, o de dependência." (Zilberberg, 2004, p. 80). Esse argumento sustenta de que maneira os timbres podem se distinguir entre si mantendo sua dependência mútua. Esse princípio pode ser posto em prática por meio de uma análise em termos de triagens e misturas de casos concretos recolhidos de nosso corpus de análise.

Para que a mistura de timbres aconteça, impõe-se como condição certo grau de compatibilidade de tessitura e dinâmica. Conforme adverte Belkin (2001, sem paginação, tradução nossa $\left.{ }^{\mathrm{xxxv}}\right)$ : "elementos musicais que estão em registros separados não são percebidos no mesmo plano sonoro". Atendidas essas condições, os timbres estarão aptos à mistura que, contudo, não ocorrerá forçosamente. A pergunta que se coloca é: uma vez que a altura e a intensidade de dois objetos sonoros permite sua fusão, o que os faz resistir à mistura em princípio desimpedida? Essa resistência é sintoma de uma incompatibilidade profunda entre timbres, como se entre eles se interpusesse certo intervalo em latência.

Evidências de tais afinidades e incongruências intertimbrísticas podem ser encontradas fixadas por escrito em manuais de arranjo e orquestração. Na impossibilidade de capturar o conjunto integral de avaliações estéticas e éticas sobre o timbre vigentes em dada cultura ou sociedade, o recurso a esse tipo de obras abre uma via de acesso para revelar as restrições semióticas que, veladamente, regem as relações de compatibilidade e incompatibilidade entre timbres. Essas relações podem ser vislumbradas em quatro grandes formações timbrísticas, que podem ser descritas pela dinâmica entre triagens e

\footnotetext{
${ }^{11}$ Cf. 88.
} 
misturas e seus respectivos estágios resultantes, a saber, fusão, mescla, contiguidade e separação (Zilberberg, 2004). ${ }^{12}$

\subsubsection{Fusão - a mistura absoluta}

Quando a mistura atinge seu ponto máximo, resulta o estado de fusão. No grau mais extremo, os contornos particularizantes de cada timbre se apagam e se consubstanciam em uma nova massa sonora uniforme e homogênea que oblitera a identidade dos timbres mesclados. A esse estado, designado "liga" em Zilberberg (2004,p. 85-87), corresponde o "aglomerado sonoro" abordado por Menezes (2003, p. 25) a partir de uma perspectiva acústica e remetendo diretamente à ideia de "massa sonora" elaborada por Schaeffer (1966). Apontando a importância das misturas e ruídos para a música eletroacústica, Menezes (2003, p. 25-29) traça um percurso progressivo que parte da onda senoidal pura e desemboca no ruído branco, tido como o mais extremo grau de mistura sonora. Segundo a exposição desse autor, isso ocorre porque, no ruído branco, todo o espectro audível de frequências é saturado simultaneamente com ondas sonoras de idêntica intensidade. Análises acústicas à parte, o que está em jogo aqui é a indistinção resultante de um recrudescimento da mistura. O ruído branco é apenas o produto mais extremo de um processo de mistura que se efetiva em diferentes graus. No domínio da música erudita ocidental, o caso mais prototípico é a fusão no naipe de cordas, de maior homogeneidade timbrística em comparação com as demais famílias instrumentais:

Consequentemente, as cordas apresentam menos problemas de mescla. E elas não variam em potência de registro para registro tanto quanto as madeiras. Isso significa que o equilíbrio é mais facilmente calculável. (Kennan, 1983,p. 179, tradução nossa ${ }^{\mathrm{xxxvi}}$ )

Ao notar que as cordas possuem "menos problemas" de mescla, o autor insinua ao mesmo tempo maior dificuldade em misturar timbres da família das madeiras. Fatores relacionados à história do desenvolvimento técnico das cordas propiciaram sua homogeneização interna antes das demais famílias. Em obra dedicada à história da orquestração, Carse (1964 [1925]) registra esse amadurecimento precoce: "O grupo que gozava da maior homogeneidade timbrística, o que menos cansava o ouvido e o que oferecia a mescla mais perfeita, a saber, a orquestra de cordas, podia falar por si só e exibir seu próprio timbre

\footnotetext{
${ }^{12}$ Essa interpretação dos estágios da sintaxe extensiva como grau de compatibilidade é legitimada por uma formulação anterior apresentada em Fontanille \& Zilberberg (2001,p. 37). Nela, um quadrado semiótico simples aloca os termos "incompatível" (s1) e "separado" (não-s2) na dêixis da triagem e os termos "adequado" (s2) e "compatível" (não-s1) na dêixis da mistura.
} 
particular sem alterações constantes." (Carse, 1964 [1925], p. 246, grifos nossos, tradução nossa $\left.^{\text {xxxvii }}\right)$.

De nossa parte, gostaríamos de dar especial destaque à intuição de que a "mescla mais perfeita" é possibilitada pelo alto grau de afinidade mútua entre os timbres das cordas. Prevista já em hipótese, essa correlação entre miscibilidade e homogeneidade aparece explicitamente assinalada na história da orquestração. Não é demasiado relembrar que, para uma investigação verdadeiramente semiótica, aspectos materiais relacionados à técnica de construção dos instrumentos interessam menos do que sua consequente uniformização sonora e sua aplicação em contextos musicais. A homogeneização do timbre das cordas se acentuou a ponto de, em determinado momento, ir apagando as sub-distinções entre os membros dessa família. Qualquer obra de divulgação musical registra esse processo de pasteurização timbrística:

Tendo em conta que, na primeira fase do Barroco a instrumentação era variável, não denotando, por conseguinte, preocupação da parte dos compositores com cores determinadas (em que pesem as exceções), a criação e estabilização da orquestra de cordas significa uma mudança acentuada. Os demais instrumentos - madeiras, metais, percussão - adquirem, a partir deste momento, relevo e função colorística por contraste. (Kiefer, 1987,p. 78)

Nessa passagem, há dois fatores em jogo. O primeiro deles é a consolidação da orquestra de cordas, que marca, na história da orquestração, a passagem de uma fase de livre projeção do timbre para uma fase de maior determinação timbrística. O segundo deles diz respeito aos papéis atribuídos aos demais naipes instrumentais, que assumem função ornamental sobre o fundo homogêneo constituído pelos timbres das cordas. É interessante notar como o risco de indistinção trazido pelo alto grau de miscibilidade mútua entre as cordas é atenuado pelos contrastes criados com timbres dos instrumentos de sopros e das percussões. A ameaça de saturação - de um "somente mais" (Zilberberg, 2011 b p. 254) - de homogeneidade é refreada por um acréscimo de diversidade timbrística.

Mais facilmente reconhecível na família de cordas a princípio, a fusão de timbres não fica apenas nela circunscrita. Ao contrário, constitui-se como um procedimento elementar que se expandiu também a outros conjuntos timbrísticos ao longo da história. Sua extensão aos "novos" integrantes da orquestra se deu paulatinamente e, com o tempo, as novas fusões de timbres passaram a integrar a técnica orquestral. Conforme apontado acima, as fusões na família de cordas foram as primeiras a se estabelecer na práxis musical. Mais tempo foi necessário para que fusões entre madeiras e metais se efetivassem, ao menos nos cânones da música erudita ocidental. Foi apenas no século XIX que os sopros 
conquistaram miscibilidade. Uma vez estabilizadas com êxito também nas regiões graves, as misturas de sopros foram legadas de compositor a compositor para, enfim, passar de fato a integrar a técnica orquestral da música europeia:

As misturas graves de clarinetes e fagotes, ou de fagotes, trombones e oficleide, os grupos agudos de partes divididas de violinos, e muitos outros efeitos encontráveis nas partituras de Meyerbeer, todos eles se destacam como patentes de muitos dos famosos mecanismos colorísticos de Wagner. (Carse, 1964 [1925] ,p. 254, tradução nossa ${ }^{\text {xxxviii }}$

Esse estágio tensivo de fusão encontra, em Wagner, sua manifestação mais notória. Não apenas a expansão numérica dos grupos instrumentais contribuem para esse efeito, mas também a composição timbrística maciça das massas sonoras de sua linguagem orquestral, conforme apontado pela seguinte passagem:

As partes de cordas na mesma ópera [Tristão e Isolda] são mais complexas, menos facilmente separáveis em material melódico ou de acompanhamento, frequentemente composta por fases minúsculas cuja função é unificar formando um tecido de movimento no qual cada parte não pode ser, e não deve ser, ouvida distintamente, uma textura sonora movente, cujos constituintes agem co-operativamente ao invés de individualmente. Partes de madeiras e trompas se entrelaçam no tecido sem anunciar sua entrada, e podem ser descobertas quando sua presença era insuspeita. (Carse, 1964 [1925] , p. 277, tradução nossa xxxix )

Tais fusões sonoras se consolidaram como uma característica própria à linguagem orquestral dos compositores alemães a partir da segunda metade do século XIX. Em Brahms, por exemplo, as partes raramente exibem sua própria qualidade sonora particular sem a conjunção de algum outro instrumento de igual tessitura, mas de timbre dissimilar (cf. Carse, 1964 [1925] , p. 295). Outro caso emblemático da mistura timbrística levada aos limites da saturação é Robert Schumann. Ainda segundo Carse (1964 [1925]), Schumann se coloca no exato oposto de Meyerbeer e Berlioz ao embaralhar todas as cores orquestrais. Para esse autor, tal descomedimento das misturas acaba erodindo o valor estético das composições desse compositor:

Menos perdoável era seu [de Schumann] frequente fracasso em garantir um equilíbrio sonoro satisfatório entre partes melódicas e harmônicas e, o menos perdoável de tudo, sua consistente negligência em permitir que as cores primárias 
da orquestra sejam escutadas em seu estado nativo e em contraste nítido com as demais. O tingimento continuamente rico de sua coloração se deve ao emprego de cordas, madeiras e trompas em constante combinação. (1964 [1925], p. 264, tradução nossa ${ }^{\mathrm{xl}}$ )

Tal avaliação negativa da saturação das misturas em Schumann não passou despercebida também aos ouvidos de Tchaikovsky, que não mede palavras para depreciar a indistinção timbrística desse compositor:

Sem entrar em detalhes técnicos, posso explicar para os meus leitores que a arte da instrumentação (i.e. a distribuição de material entre diversos instrumentos) consiste em entender como empregar alternativamente os grupos instrumentais individuais; como mesclá-los apropriadamente; como economizar efeitos fortes - isso é, a aplicação do timbre (cor do som) a ideias musicais. Esse conhecimento, Schumann não adquiriu. Sua orquestra trabalha continuamente; todos os instrumentos participam da exposição e desenvolvimento de suas ideias. Eles não são usados em destaques, não há nenhum contraste entre eles (e efeitos de contraste são inesgotáveis em orquestração); a maior parte do tempo, eles se fundem em um rugido contínuo, frequentemente arruinando as melhores partes de uma obra. (Newmarch, 1900, apud Carse, 1964 [1925],p. 306, tradução nossa ${ }^{\text {xli }}$ )

Não sem certo tom de depreciação, Carse (1964 [1925]) reporta o espraiamento do uso ostensivo dos tutti orquestrais também às operas italianas e francesas.

Os tutti orquestrais marcaram o início de uma tendência de parte de muitos compositores de óperas italianos e franceses a se contentar com um tipo ruidosamente explosivo de tutti no qual partes esguias de violino e flauta se debatem contra uma pesada harmonia do restante da orquestra. Mesmo se uma parte de piccolo socorresse, às vezes, a parte melódica de ser completamente tragada por uma torrente de acompanhamento harmônico, não se pode dizer que o tipo de tutti tão frequentemente encontrado nas aberturas operísticas, como em Boieldieu, Rossini, Hérold e Auber, se degenerando, como frequentemente o faziam, em um ruído mais ou menos extravagante, seja em qualquer coisa semelhante ao bom equilíbrio daquele [tutti] de Weber. (Carse, 1964 [1925], p. 239, tradução nossa xlii)

Sem ocultar suas preferências estéticas, Carse (1964 [1925]) reitera os efeitos negativos da fusão timbrística. Em uma interessante projeção hipotética, o autor mostra como 
a sucessão vertiginosa da máxima saturação de variedade acaba, no limite, aniquilando a própria percepção da mistura como tal. Sendo assim, o efeito de heterogeneidade exige a manutenção de certa margem mínima de distinção entre os timbres. ${ }^{13}$

Compositores escrevendo ao final desse século [XIX] frequentemente corriam o risco de exaurir o ouvido por trocas de timbres demasiadamente frequentes ou, em outras palavras, por uma variedade agrupada com demasiada proximidade. O fato de que há um risco pode ser provado ao levar esse processo a extremos. Se fosse possível produzir sessenta variedades diferentes de timbres em sucessão durante o curso de um minuto, e se fosse possível então continuar a proverlhes em variedade infinita por um quarto de hora, o ouvido não estaria consciente de ter escutado nenhum deles; eles simplesmente se mesclariam em uma avalanche contínua de som da mais mortal monotonia. Portanto, ao prover a maior variedade de timbres em intervalos demasiadamente breves, o ouvido, não tendo tempo de se demorar em nenhum deles, fracassa em reconhecer qualquer variedade que seja." (Carse, 1964 [1925] , p. 332-333, tradução nossa xliii )

Quando levada a seus limites extremos, a mistura desemboca em um estado de saturação suprema, em que a adição de novos timbres chega a ser virtualmente impossibilitada. É interessante notar que, aqui, o que está sendo negativamente valorado é o excesso, assinalado pela recorrência de termos como "demasiadamente", "extremo" e seus correlatos, como se conclamasse por uma diminuição (menos mais) e um retorno à justa medida. Nessa fronteira final da mistura, somente a incorporação do ruído (tais como aqueles produzidos por maquinários e aparelhos elétricos) poderia redemarcar esses limites, expandindo-os. Antes que os movimentos vanguardistas do século XX propusessem tal repatriação sonora (cf. Russolo, 2003 [1913]) e movimentos como o impressionismo e o minimalismo viessem refrear essa hipertrofia timbrística, a orquestra do final do século XIX se viu paralisada diante da impossibilidade de acrescentar variedade a seu conjunto.

Nenhuma variedade posterior poderia ser obtida mesmo dessa gigantesca orquestra enquanto o mesmo percurso de desenvolvimento estivesse sendo perseguido. Nenhuma coloração nova poderia ser criada pelo mero aumento em volume de som; Strauss obteve tantas cores em sua paleta orquestral que sua mistura contínua não produzia nuanças novas. (Carse, 1964 [1925] ,p. 321, tradução nossa ${ }^{\text {xliv }}$ )

\footnotetext{
${ }^{13}$ Aplicando esse mesmo ferramental analítico ao estudo da intolerância em contexto social, Barros (2014a) faz notar que o grau paroxístico de mistura acaba por desembocar na aculturação e na supressão da alteridade de grupos minoritários.
} 
Mais adiante, o autor volta a enfatizar o "beco sem saída" alcançado pelo aumento recursivo da mistura, em uma operação de mais mais que chegou a esgotar a renovação de possibilidades combinatórias. Não apenas a variedade da paleta timbrística atingiu seu limite à época, mas também sua sequencialização exagerada e demasiadamente constante reduzia o poder de impacto pretendido pelos contrastes entre timbres. Vale a pena chamar a atenção para a ideia de indistinção e monotonia - de nossa parte, acrescentaríamos ainda "atonia" - decorrentes da sobrecarga de cores orquestrais:

[...] porém, se as lições da orquestração teutônica dos primeiros anos desse século foram apropriadamente aprendidas, elas certamente comprovarão ter mostrado que a orquestração não tem nada mais a ganhar com o mero aumento de volume de som; que variedade de cor, de tratamento e de textura, têm mais a oferecer; que o ouvido julgará, a longo prazo, a tensão contínua e a complexidade de construção tão monótonas quanto uma indistinção contínua, e que períodos de repouso por si só podem servir para proporcionar aos períodos de entusiasmo e energia seu devido efeito. (Carse, 1964 [1925], p. 322, grifos nossos, tradução nossa ${ }^{\text {xlv }}$ )

Impedida de crescer em variedade, restou à orquestra europeia do final do século XIX apenas o aumento numérico de seus membros. Essa expansão quantitativa não surte, porém, os mesmos efeitos estéticos de contraste timbrístico. ${ }^{14}$ Tal excesso de mistura chega ao limite de demandar um movimento contrário de atenuação, um certo "menos mais" (cf. Zilberberg, 2011b) de timbres a lhes devolver sua margem mínima de identidade:

Ao adicionar mais ao número de instrumentos já representado, e ao adicionar ainda mais representantes do mesmo tipo, porém de altura mais alta ou mais baixa, o volume de som disponível foi aumentado, porém sem ganho correspondente de variedade de efeito. O tempo provavelmente mostrará que o ápice do crescimento da orquestra, isto é, meramente considerando seu tamanho ou número, foi atingido por volta do início do presente século $[\mathrm{XX}]$, e que a orquestração àquela época não devia seus avanços ulteriores para o ampliado volume sonoro, mas antes à ampliada variedade de tratamento dos instrumentos, ou dos grupos instrumentais, que já eram membros combinatórios estabelecidos firmemente e desde longa data. (Carse, 1964 [1925], p. 314 , tradução nossa ${ }^{\text {xlvi }}$ )

\footnotetext{
${ }^{14}$ Grosso modo, trata-se aqui de uma distinção semelhante àquele, corrente em linguística, entre tipo (type) e ocorrência (token).
} 
Já se afastando dos modelos que se consolidaram até o Romantismo, boa parte da música do século XX também lançou mão da mistura extrema de timbres. Para ir um pouco além dos casos mais ilustres, como Schoenberg, Weber, Xenakis e Ligeti, um compositor menos relembrado como Giacinto Scelsi revelou todas as potencialidades das ligas de timbres. Sobre essa particularidade estilística, assim nota Bonnet (2012):

A música de Giacinto Scelsi, por exemplo, é uma música de indistinção. Ela própria não é puramente indistinta, mas ela procede por indistinção pelo menos em dois níveis. [...] As obras de Scelsi são, antes de tudo, massas, fluídos em fusão em que se amalgamam de maneira fantástica as sonoridades dos instrumentos e em que o fenômeno acústico prima sobre uma organização nota por nota. [...] A música de Scelsi prefigura a possibilidade de um uso único do drone como paradigma musical. [...] Em Scelsi, como nos drones, a música se concebe bem mais como uma matéria fluída, uma energia, do que como a manifestação de um discurso se desenvolvendo no tempo. (Bonnet, 2012 , p. 200, tradução nossa $\left.{ }^{\text {xlvii }}\right)$

Não é demasiado frisar que esse procedimento de mistura máxima de timbres se estabelece como um recurso semiótico intrínseco à linguagem orquestral-instrumental em si e não está restrito ao capricho idiossincrático de compositores ou de escolas estéticas. Aqui, o que está em jogo são os mecanismos tensivos subjacentes que regulam o equilíbrio de timbres na orquestração. Como se pode observar, a saturação extrema da mistura acaba demandando inevitavelmente um contramovimento de atenuação - um "menos mais" na terminologia de Zilberberg $(2011 a, b)$. No entanto, esse jogo de misturas (e suas triagens consequentes) não se limitam apenas a combinatórias timbrísticas a bel prazer, mas também trazem consequências para a organização melódica e harmônica global do texto.

Tendencialmente, fusões de timbres são atribuídas a texturas polifônicas e/ou acompanhamento harmônico. Entre outras coisas, a construção de uma polifonia bemsucedida precisa levar em conta também o grau de miscibilidade dos timbres postos em cena. Por toda parte, a crítica estética e as histórias da orquestração dão evidências da estabilidade dessa correlação. Ao discorrer sobre a música barroca, Harnoncourt (1982) aponta a importância das mesclas timbrísticas bem integradas ao conjunto sonoro total:

[...] : a música dos séculos passados desenvolvia todas as suas forças no refinado tecido polifônico ; cada instrumento, cada musicista era uma parte anônima do todo. Cada instrumento deveria desenhar sua linha tão claramente quanto 
possível e misturar ao mesmo tempo sua tinta particular à sonoridade do conjunto. Ora, por volta de 1600, novas forças entraram em jogo. [...] Mesmo a música puramente instrumental foi arrastada por essa onda e o solista sai do anonimato que era aquele do musicista de conjunto. (Harnoncourt, 1982 ,p. 146-147, grifos nossos, tradução nossa ${ }^{\text {xlviii }}$ )

O emprego metafórico do termo "anonimato" para designar a fusão timbrística parece corroborar a hipótese de que timbres com investimento figurativo rarefeito se desindividualizam e, com isso, tendem à mistura. Esse caminho é o oposto daquele traçado pelos timbres exclusivos que, ganhando em adensamento figurativo ${ }^{15}$, começam a se inclinar à triagem. ${ }^{16} \mathrm{Na}$ passagem em questão, esse movimento aparece assinalado no ganho de autonomia do solista, que, nas palavras do próprio autor, "sai do anonimato".

Na história da orquestração, a conquista dessa autonomia chegou em diferentes tempos para cada timbre que, hoje, integra o corpo da orquestra. A título de exemplo, a família de sopros foi se desenvolvendo paulatinamente ao longo dos séculos. Por longo tempo, instrumentos como fagote, clarinete e oboé foram relegados ao papel subalterno de "recheio timbrístico", recebendo apenas uma escrita melodicamente simples. A esse respeito, Harnoncourt (1982) faz os seguintes apontamentos sobre as inovações orquestrais trazidas por Telemann:

O fagote não tem voz própria e acompanha simplesmente os violoncelos e os contrabaixos; [...] No entanto, Telemann exige um quarteto completo de sopros: três oboés e fagote. [...] Essa possibilidade conduz a um modo de escrita particular: agora, o diálogo não se desenvolve mais apenas no interior de sonoridades homogêneas por alternância de motivos e figuras, mas sim entre grupos sonoros fundamentalmente diferentes. (Harnoncourt, 1982 , p. 224, tradução $\operatorname{nossa}^{\text {xlix }}$ )

A passagem merece atenção por flagrar o exato ponto de virada em que o fagote deixa de ser apenas um timbre componente de fusão completa e passa a ganhar uma fisionomia própria, gerando assim grupos sonoros mais heterogêneos. Nesse exato ponto, uma interessante transformação ocorre: um timbre que, até então, nada fazia além de engrossar misturas timbrísticas começa a ganhar traços particularizantes que fazem emergir sua individualidade timbrística por sobre a "multidão sonora" dos tutti e das polifonias maciças. Passa-se, assim, do estado de fusão para o estado de mescla.

\footnotetext{
${ }^{15}$ Cf. Cap. 2.

${ }^{16}$ Cf. p. 130 adiante.
} 


\subsubsection{Mescla - dominância parcial da mistura}

O estágio de mescla pode ser obtido por duas vias: ora por uma operação de mistura que já se encaminha rumo à sua consumação, ora por uma operação de triagem ainda incipiente. Ambos os caminhos desembocam, no entanto, na mesma composição mereológica de superfície. A título de exemplo, esse segundo cenário será o estado resultante após a dissolução da fusão do fagote no corpo da orquestra, ilustrado pela passagem comentada acima.

É por esse mesmo processo de triagem que a família das madeiras e, mais tarde, a dos metais, vão se emancipando. Esses timbres ainda conservam, no entanto, certo grau de miscibilidade e não atingem independência absoluta. Sob determinadas condições, as mesclas com outros tipos timbrísticos permanecem possíveis, o que garante às técnicas de orquestração sua flexibilidade e amplitude criativa. Grosso modo, pode-se reconhecer uma mescla sempre que determinado timbre (ou conjunto de timbres) começa a receber material musical autônomo, como o mostra o seguinte excerto:

O grupo das madeiras, menos coeso mas bastante distintivo, podia igualmente ter sua parte como um grupo independente, apesar de uma tendência a se amalgamar frequentemente com o som das trompas. Os metais, agora usufruindo do grande benefício de pelo menos três membros completamente cromáticos, a saber, os trombones, tinham se tornado mais ou menos autônomos harmonicamente, e poderiam falar por si só sem a cooperação de tipos intrusos de instrumentos. (Carse, 1964 [1925] ,p. 246, tradução nossa ${ }^{1}$ )

Ao dispensar outros "tipos intrusos de instrumentos", os metais deixam de funcionar apenas como estofo timbrístico, o que aponta para um processo de triagem começando a se efetivar. Ainda nesse mesmo trecho, a afinidade entre o timbre das madeiras e o das trompas demonstra como a mescla pode resultar também de uma operação de mistura já em vias de se completar. Ao contrário dos demais integrantes da família de metais, o timbre de trompas se deixa imiscuir mais facilmente aos timbres do naipe de madeiras. Evidência disso é a frequente ocorrência, na linguagem orquestral, de mesclas sonoras do tipo [trompa+fagote], [trompa+flauta+clarinete] entre outras (cf. Rimsky-Korsakov 1922a [1873-1874],p. 24). Comportando-se à maneira de um "aglutinante timbrístico", o timbre de trompa se coloca em uma interface entre metais e madeiras que, de outro modo, permaneceriam inaderentes entre si:

Por causa do timbre, [a trompa] é por muitos considerada um instrumento pertencente tanto ao naipe dos metais quanto ao 
das madeiras. De fato, a trompa combina excepcionalmente bem com os instrumentos desta última classe (em especial, com a clarineta), sendo talvez o melhor exemplo o já visto quinteto de sopros, uma das formações camerísticas mais consagradas dentre as existentes. (Almada, 2014 [2000], p. 261)

Ocupando essa mesma intersecção, pode-se mencionar como simétrico oposto da trompa o timbre de saxofone. Sendo em princípio um membro da família das madeiras, o saxofone é frequentemente aglutinado a trombones e trompetes para compor trios de metais (Almada, 2014 [2000], p. 126-127), como ocorre por exemplo em formações de frevo e big band. Para retornar ao domínio da música erudita, outro exemplo de mescla consagrada pelo uso e tornada idiomática é a simbiose entre violino e oboé, amplamente produtiva na linguagem orquestral do período barroco.

A orquestra da primeira metade do século XVIII era um 'instrumento' ajustado muito finamente em seus timbres e na fusão de suas cores. [...]. É evidente que, para uma instrumentação tal, é de grande importância a maneira particular pela qual as sonoridades dos instrumentos se mesclam entre si. Assim, por exemplo, a sonoridade misturada do oboé e do violino é verdadeiramente a espinha dorsal da sonoridade da orquestra barroca. Essa escrita colla parte é preenchida por solos instrumentais em concerto, nos quais os diversos grupos instrumentais (trompetes, flautas, oboés, cordas) se destacam avulsos da sonoridade fundida dos blocos em tutti [...]. (Harnoncourt, 1982 ,p. 151, tradução nossa ${ }^{\text {li }}$ )

No excerto acima, vale a pena também destacar o jogo de contrastes timbrísticos entre os blocos em tutti, típicos exemplares do estado de fusão descrito anteriormente ${ }^{17}$, e o timbre dos solistas. Não é ocioso registrar que, enquanto estes são enumerados um a um - ainda que de maneira apenas alusiva - os componentes do tutti mal se deixam discriminar em sua individualidade. Essa correlação entre grau de mistura e identidade timbrística $^{18}$ é uma evidência sintomática da produtividade da sintaxe extensiva aplicada à distinção e categorização de timbres.

Ainda sobre o período barroco, Harnoncourt (1982) aponta também certa tendência a mesclar o fagote com outros timbres para conferir maior nitidez de contorno melódico: "O fagote barroco faz soar realmente [o naipe de] madeira, quase como um instrumento de cordas, [...] . Ele é concebido de maneira a se fundir de maneira ideal com o violoncelo e o cravo no baixo contínuo, mas ao mesmo tempo a dar ao baixo um

\footnotetext{
${ }^{17}$ Cf. Seção 4.2.1.

${ }^{18}$ Cf. Cap. 2.
} 
traçado e um contorno claros." (1982, p. 156, tradução nossalii). Mais adiante, o autor volta a enfatizar como essas mesclas no baixo contínuo contribuíram para consagrar a paleta timbrística hoje associada tipicamente à música do período barroco: "Porém, para destacar e reforçar a linha de baixo de maneira correspondente, a gamba, o violoncelo ou o contrabaixo, às vezes mesmo o fagote, executam a voz mais grave com o cravo o mais frequentemente possível." (1982,p. 158, tradução nossa liii $)$

De fato, aglutinar timbres para ampliar a densidade sonora de partes determinadas constitui um expediente produtivo na técnica orquestral. Seja para tonificar efeitos expressivos construídos na harmonia ou para criar contrastes entre partes, esse recurso depende em grande medida de um ajuste equilibrado entre timbres, alguns dos quais destinados unicamente para esse fim. Nos dias de hoje, pode parecer difícil conceber um instrumento musical incapaz de assumir melodias por si só. No entanto, isso nem sempre foi verdadeiro, ao menos a considerar a história da música erudita ocidental. Tome-se como exemplo os trombones, cujo timbre não revestia melodias autônomas antes de meados do século XIX; até então, ele funcionava apenas como preenchimento harmônico:

Estes últimos [o trio de trombones] eram tratados quase completamente como harmonistas, exceto ocasionalmente, quando material adequado na parte dos baixos propiciava algum interesse temático. Mais recente era o uso de trombones para harmonia muito suave, conforme ocorre em algumas das últimas sinfonias de Schubert e nas óperas de Weber. O uso de trombones em certos momentos unicamente com o fim de dar mais volume para acordes particulares, ou para construir e enfatizar um clímax, mostra algum avanço sobre o estilo mais antigo, o qual mantinha esses instrumentos soando mais continuamente nos movimentos dos quais eles participavam. [...]; assim, o som de metais não misturados era um efeito amplamente negado a compositores do início do século XIX. (Carse, 1964 [1925] ,p. 229-230, tradução nossa ${ }^{\text {liv }}$ )

A passagem em questão mostra como o trombone não tinha autonomia e, durante certo tempo, sequer podia ser empregado a não ser para compor misturas timbrísticas. Essa circunscrição afeta toda uma classe de timbres impossibilitada de carregar melodias solistas. Eventualmente, pode-se ainda objetar que, ao longo do tempo, o trombone conquistou plena autonomia melódica, como testemunhado fartamente por estilos populares como a gafieira. Embora possa parecer trivial, tal constatação atesta o resultado da ação paulatina do processo de triagem incidindo sobre toda essa gama de timbres que, até então, estavam fadados à mistura. No âmbito da música erudita europeia, um dos casos mais emblemáticos é a viola. 
Para além das frases imitativas que ocorriam ao longo da polifonia de quatro partes para cordas, a viola como naipe e sem reforço quase não era reconhecida como melodista e também não há razão para crer que o timbre particularmente atraente e individual da viola fosse apreciado nesse período, apesar da sugestiva iniciativa de Gluck e da prontidão de Weber para explorar as possibilidades dramáticas desse instrumento negligenciado. Tanto Berlioz quanto Wagner testemunharam o status e a habilidade inferior dos violistas mesmo em uma época posterior e não é difícil ver como as condições vigentes são refletidas nas partes de viola escritas no início do século. (Carse, 1964 [1925] , p. 226-227, tradução nossa ${ }^{\text {lv}}$ )

A exemplo da viola, o excerto em questão sintetiza como se dá o imbricamento mútuo entre, de um lado, a predisposição latente ${ }^{19}$ de um timbre às misturas e, de outro lado, a atrofia melódica que caracteriza sua escrita. Um forte indício disso é a consabida escassez de peças para viola solo na literatura musical, que só no século XX ganhou proeminência nesse papel. (cf. Druce, 2015) Inversamente, pode-se inferir um cenário simétrico oposto: o protagonismo melódico de um dado timbre evidencia sua propensão à triagem. Em termos mais amplos, há uma dependência íntima entre a cifra tensiva subjacente de um timbre e a configuração de seu subtrato rítmico-melódico. ${ }^{20}$

Esse vínculo explica também o longo processo de emancipação do naipe de madeiras, que, em meados do século XIX, ainda não tinha conquistado plena autonomia com relação à orquestra de cordas, como o mostra o seguinte trecho acerca da orquestração de Brahms: "As madeiras como um naipe ganham uma parcela bem generosa de material musical, dobrando umas as outras cada qual em seu respectivo registro ou então, com menos frequência, atuando como um grupo independente, mas raramente como solistas desimpedidos." (Carse, 1964 [1925] , p. 295-296, tradução nossa lvi) O mesmo se aplica também ao uso das trompas por esse mesmo compositor: "As trompas agem como material de ligação e são quase sempre empregadas continuamente como tal, provendo uma coesão algo monótona por meio de partes que não são exatamente melódicas, porém são mais do que mero estofo harmônico." (Carse, 1964 [1925], p. 296, tradução nossa lvii)

É digna de nota a observação de Carse (1964 [1925]) sobre o caráter híbrido da escrita para trompas de Brahms - além do acompanhamento harmônico e aquém de um verdadeiro protagonismo melódico. Nas entrelinhas de uma passagem sucinta e aparentemente trivial como essa, pode-se entrever a ação de um percurso tensivo ascendente, flagrado no uso não-incidental de expressões como "mais do que mero". Ainda

\footnotetext{
${ }^{19}$ Pode-se questionar aqui a causa de tal predisposição: procederia ela do timbre intrinsecamente ou das normas estéticas vigentes em determinado contexto socio-histórico? Embora seja mais provável uma interação cruzada de ambos os fatores, uma resposta mais precisa a essa questão exige mais evidências a serem levantadas por estudos posteriores.

${ }^{20}$ Cf. Cap. 5.3.3, p. 182 ss.
} 
sem maturidade melódica para agir como solistas, as trompas em Brahms servem antes como aglutinante sonoro, costurando mesclas timbrísticas entre partes que, de outro modo, correriam o risco de apenas se justapor incongruentemente.

Ainda no século XIX, vemos essa técnica de entrelaçamento timbrístico ser amplificada ao extremo por um compositor como Edward Elgar. Valendo-se de toda a paleta timbrística disponível na orquestra de seu tempo, Elgar esmaeceu as linhas separadoras entre partes que, em outros compositores, permanecem nitidamente distintas. As peculiaridades desse estilo não passaram despercebidas na história da orquestração: "Contrastes muito acentuados são, em geral, evitados atenuando os contornos colorísticos por um processo de sobreposição de timbres, uma característica de Elgar que foi crescendo conforme se deu o desenvolvimento de seu estilo orquestral." (Carse, 1964 [1925] , p. 326, tradução nossa lviii $)$. Mais adiante, o autor volta a sublinhar o caráter singular dessa técnica:

A individualidade de Elgar em sua orquestração repousa em sua capacidade altamente desenvolvida de mesclar timbres; as cores primárias da orquestra raramente são empregadas em estado puro. [...] As partes são distribuídas de maneira a prover contrastes colorísticos em abundância, mas esses se mesclam uns nos outros sem expor limites claramente definidos. (Carse, 1964 [1925], p. 327, tradução nossa ${ }^{\text {lix }}$ ).

A preferência explícita desse compositor pelas mesclas é empregada para criar contrastes matizados por sutis gradações. Nesse sentido, a técnica empregada por Elgar se assemelha ao apagamento de contornos típico da pintura barroca, para retomar o estudo semiótico de Zilberberg (1992) sobre os estilos picturais. Por esse ângulo, seu estilo se opõe diametralmente àquele praticado por outros compositores que, reforçando contornos e fronteiras entre as partes, dispõem de características semelhantes ao estilo da pintura renascentista, ainda para resgatar Zilberberg (1992). É o que mostra a seguinte passagem, comparando o estilo desse compositor com o de Tchaikovsky:

Enquanto Tchaikovsky visava uma definição muito clara de cada parte concentrando instrumentos de timbre análogo em uma parte qualquer, Elgar seleciona vários tipos de timbres e lhes assegura riqueza e sonoridade idênticas porém contornos de partes menos claramente definidos. (Carse, 1964 [1925], p. 327 , tradução nossa ${ }^{\mathrm{lx}}$ ).

Mais do que exclusividade dos caprichos criativos deste ou daquele indivíduo, a mescla é parte inerente do mecanismo tensivo que subjaz a toda textualização orquestral 
e instrumental. Se, de livre escolha, optamos por apresentar Elgar como exemplo emblemático do emprego das mesclas, isso não implica porém que ela não tenha sido produtiva nas mãos de outros compositores. É o caso de Schubert. Ao comentar o estilo orquestral de sua fase madura, Carse (1964 [1925]) aponta como característica marcante a distinção equilibrada entre uma função melódica e uma função harmônica, sendo esta última sempre assentada sobre mesclas timbrísticas bem balanceadas.

Suas [de Schubert] atraentes melodias de cordas são acompanhadas por mesclas robustas de madeiras; suas melodias de madeiras [são acompanhadas] por cordas bem discretas. Trompas são usadas para dar riqueza e corpo para as harmonias nas madeiras, ou para se mesclar aos fagotes em suave cooperação.(Carse, 1964 [1925], p. 236, tradução nossa ${ }^{\text {lxi }}$ )

Nessa passagem, observa-se como a base harmônica em Schubert é constituída frequentemente por mesclas timbrísticas estáveis conglomerando trompas e madeiras ou trompas e fagote, corroborando a observação sobre o papel de facilitador de mesclas desempenhado pela trompa. ${ }^{21}$ Além disso, são citadas também as mesclas homogêneas de madeiras e cordas como possibilidades timbrísticas para o alicerce harmônico.

Vale a pena também notar a oposição implícita entre sonoridades suaves ${ }^{22}$ e ásperas. Essa distinção pode ser depreendida quando o autor descreve o uso do timbre de trompas mesclado aos de fagotes com o intuito de amenizar a sonoridade destes últimos, presumivelmente mais incisivos e ásperos em estado puro. Esse testemunho sugere que o timbre de trompas se comporta como um atenuador, operando um "menos mais", para fazer valer a terminologia de Zilberberg (2011b). Esse efeito de atenuação se associa também à sua constituição morfológica, tendo em vista a já notada correlação entre a cifra de andamento da fase de ataque de um timbre e sua percepção como mais "macio" ou mais "incisivo". ${ }^{23}$ Desdobrando esse raciocínio com mais vagar, pode-se predizer que a inclusão de timbres com ataque desacelerado - como é o caso da trompa, da flauta doce e de aerofones de maneira geral - resultará em uma mescla timbrística suavizada. É exatamente o que captura Harnoncourt (1982) na seguinte passagem a respeito do emprego do órgão na função de baixo contínuo: "A suavidade de sua [do órgão] sonoridade permite preservar as inúmeras pinturas sonoras muito sutis que realizam os instrumentos de cordas - o que não é o caso com o ataque incisivo do cravo." (Harnoncourt, 1982 , p. 195, grifos nossos, tradução nossalxii).

No excerto em questão, é digna de nota a imbricação mútua entre perfil aspectual (notadamente, a oposição implícita ataque incisivo vs. ataque suave) e a lógica de misturas e

\footnotetext{
${ }^{21}$ Cf. p. 108.

${ }^{22}$ Smooth-toned no original em inglês

${ }^{23}$ Cf. p. 79 ss.
} 
triagens implicada na interação entre baixo contínuo e naipe de cordas. O melhor equilíbrio da mistura está condicionado à seleção de um timbre de perfil aspectual compatível com o conjunto timbrístico como um todo. Semelhante processo se deu também com a paulatina agregação do clarinete ao corpo da orquestra. Por concretizar de maneira clara muitos dos mecanismos semióticos debatidos aqui, tomamos a liberdade de apresentar na íntegra um excerto mais longo sobre a questão:

A despeito do exemplo de Mozart, o clarinete começou a se impor apenas muito gradualmente como um instrumento solo e, nessa capacidade em particular, não estava em pé de igualdade com as demais madeiras até o começo do fim do primeiro quarto do século XIX. A facilidade com a qual o som de clarinete se mescla com o som dos fagotes, das trompas e com o som das cordas tinha uma influência muito mais abrangente na orquestração como um todo do que o ganho de uma nova voz solista. As combinações suaves de clarinetes e fagotes, ou clarinetes, fagotes e trompas, começaram a substituir as combinações de madeiras, nas quais o som mais incisivo do oboé sempre tinha lugar antes quando, no começo do século XIX, os recém-chegados tinham garantido por último um lugar seguro em todas as orquestras. Uma preferência distinta pelas mesclas mais quentes e arredondadas, nas quais o som do clarinete substituiu amplamente o som até então predominante do oboé, é uma marca da orquestração que se tornou muito proeminente durante a maturidade de Beethoven, Weber e Schubert, e assinala o fim do longo reinado do oboé como chefe e condutor do naipe de madeiras. Outras mesclas sem oboés, e que se tornaram mais comuns durante o mesmo período, eram trompas e fagotes, assim como flautas e clarinetes. (Carse, 1964 [1925], p. 228-229, grifos nossos, tradução nossa ${ }^{\text {xiii }}$ )

O caráter incisivo do oboé mencionado de passagem se deixa relacionar com seu ataque mais pronunciado, semiotizável em termos de perfil aspectual. ${ }^{24} \mathrm{~A}$ busca por uma mescla mais arredondada - para retomar os termos do autor - implicava não só a diminuição das sonoridades cortantes, para a qual contribuiu a exclusão do timbre de oboé, mas também, correlativamente, o acréscimo de timbres com ataque mais suave, i.e. em termos temporais-aspectuais, aqueles com a fase de ataque mais desacelerada.

A maneira de efetivar essas mesclas timbrísticas nunca pode ser estabelecida em termos universalizantes, motivo que levou tratadistas a dedicar volumosas obras a um ofício que resiste a descrições exatas. A busca pela "receita" ideal teve de se defrontar com o fato de que o timbre não se comporta de maneira idêntica na totalidade de seu registro.

\footnotetext{
${ }^{24}$ Cf. Capítulo 3, p. 79 .
} 
Se os atuais sintetizadores eletrônicos conseguem atingir um grau antes inimaginável de uniformidade timbrística, o mesmo não se pode dizer dos instrumentos de sopro, cujo timbre está irremediavelmente atrelado às oscilações somáticas do sujeito. ${ }^{25}$ Apenas a título de exemplo, a flauta transversal assume maior proeminência dinâmica em seu registro mais agudo (Koechlin, s/d, p. 8), ao contrário do que ocorre com o fagote (Piston, 1955, p. 193). ${ }^{26}$ Ainda na mesma linha, o timbre de clarinete ganha em nasalidade e volume sonoro em seu registro grave, ao passo que a flauta transversal perde em projeção sonora e apenas raramente consegue atingir uma intensidade que ultrapassa o mezzoforte. Para além desses casos meramente ilustrativos, o que os estudos no campo da instrumentação e da orquestração revelaram é a relevância da distinção entre um registro forte e um registro fraco para cada instrumento. Mais do que insistir nesse fato consensual entre musicistas, arranjadores e compositores, queremos sublinhar aqui suas imbricações com a miscibilidade entre timbres. Quando aborda a maneira ideal de construir acordes usando flauta e oboé, Piston (1955) alerta enfaticamente para a necessidade de respeitar o registro forte de cada timbre, sob o risco de obliterar o equilíbrio sonoro resultante:

Em geral, uma disparidade resulta da associação, em um acorde de um registro fraco com um registro forte do mesmo instrumento (Fig 154a). Da mesma forma, combinar sons do registro fraco de um instrumento com os sons do registro forte de outro instrumento provavelmente resultará em um equilíbrio precário.

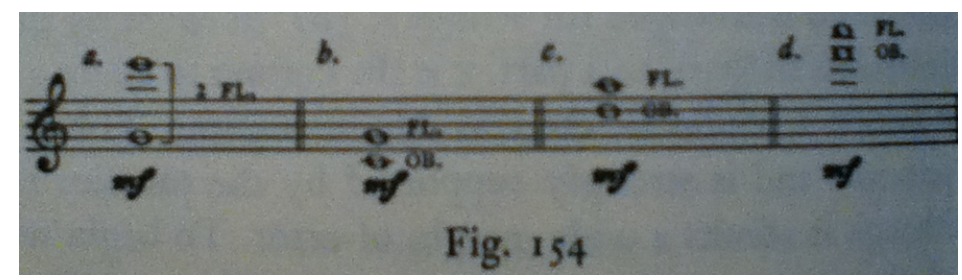

Não é demasiado enfatizar que exemplos de acordes para combinações instrumentais são válidos apenas para a altura na qual eles foram dados. Se um acorde é transposto, a relação entre registros muda. Na figura 154(c), flauta e oboé estão equilibrados adequadamente, ao passo que em (d) a flauta tem uma clara vantagem sobre o oboé.

(Piston, 1955 ,p. 446, tradução nossa ${ }^{\text {lxiv }}$ )

Tomamos a liberdade de expor esse trecho mais longo em sua íntegra para mostrar que mesmo as ligas timbrísticas mais equilibradas não estão isentas de restrições

\footnotetext{
${ }^{25}$ Em termos semióticos, essa variabilidade está vinculada ao que Carmo Jr. (2005) trata como grau de inerência das próteses musicais.

${ }^{26}$ A respeito especificamente dessa correlação entre timbre e altura, cf. Shimoda (2015).
} 
relacionadas à compatibilização do registro de seus componentes. No abstrato plano das harmonias, uma transposição de acordes não interfere em sua estruturação. No entanto, a consubstanciação desses sons em timbres concretos demandará a fixação em um registro específico. Assim, a transposição não se faz sem prejuízo do equilíbrio das mesclas timbrísticas. Note-se que, das combinatórias possíveis apresentadas pelo autor, apenas (c) é considerada bem-formada; nos demais cenários, observa-se um desequilíbrio indesejável entre os timbres da flauta e do oboé.

Tal tendência da flauta a esmaecer perante outros timbres mais marcantes é observada também na seguinte advertência de Almada (2014 [2000]): "Por exemplo, uma flauta em registro demasiadamente grave (onde é muito frágil), tocando em uníssono (ou em terças etc.) com um fagote em sua região superaguda (que o leva, naturalmente, a soar de forma tensa e áspera), tende a 'desaparecer' por completo." (Almada, 2014 [2000] , p. 109). Na mesma direção, a relativa fragilidade timbrística da flauta baixo e do sax soprano exige que eles sejam combinados preferencialmente com outros instrumentos que não ofusquem a identidade de seu timbre (cf. (Almada, 2014 [2000], p. 118, 124)). Cumpre notar que tal dissimetria nem sempre é um defeito a ser corrigido. Em certos casos, ela é empregada propositalmente para matizar as colorações do arranjo. Conforme aponta esse mesmo autor, o "timbre algo neutro" da clarineta na região do clarino para cima se deixa assimilar em combinação com instrumentos de "personalidade tímbrica forte" e, com isso, torna-a mais propensa aos dobramentos harmônicos (2014 [2000], p. 120).

Nos limites a que se propõe o presente trabalho, seria improdutivo abordar casoa-caso todas as combinatórias possíveis; explorá-las é ofício do arranjador e do compositor. Por seu lado, o que interessa a uma investigação semiótica é, antes, apontar como a miscibilidade entre timbres não se dá em absoluto, mas sim pode covariar também em função dos parâmetros sonoros de altura e intensidade. Até o momento, ajustamos nosso foco sobre os estados tensivos da fusão e da mescla. Chegando a essa altura, é preciso no entanto se perguntar: o que acontece quando a triagem passa a prevalecer sobre a mistura? É o que passaremos a investigar desse ponto em diante.

\subsubsection{Contiguidade - dominância parcial da triagem}

Definível como o simétrico inverso da mescla, a contiguidade é o estágio tensivo onde a mistura se curva perante a força da triagem sem que essa, no entanto, atinja ainda sua força absoluta. Zilberberg (2004) sintetiza tal dominância relativa pelas fórmulas $[\mathrm{m}>\mathrm{t}]$ para a mescla e $[\mathrm{t}>\mathrm{m}]$ para a contiguidade, sendo que $t$ designa a triagem e $m$ designa a mistura. Embora apenas aproximativa, tal representação simbólica tem o mérito de explicitar como se dá a relação de subcontrariedade entre mescla e contiguidade.

Devido a sua vizinhança no gradiente tensivo, a passagem entre esses estágios 
é porosa, o que é apontado em Zilberberg (2002, 2004) como característica dos limiares. Em consequência disso, a distinção entre mescla e contiguidade nem sempre se deixa reconhecer nos objetos empíricos com imediata clareza. A permeabilidade entre esses dois estados exige alto refinamento do olhar do analista para distinguir a predominância da triagem ou da mistura em cada caso particular. Segundo a conceptualização de Zilberberg (2004), o estado de contiguidade pode resultar ora de uma mistura ainda em fase inicial, ora de uma triagem já em fase final. Tanto em um quanto em outro cenário, o que justifica a denominação "contiguidade" é a fronteira bem demarcada entre os elementos justapostos.

No caso do timbre, isso ocorre nas sonoridades que conservam certa identidade particular dos timbres a despeito da ação da mistura que os justapõe. Na práxis orquestral, esse recurso frequentemente é empregado para realçar contrastes. Para que a contiguidade se mostre como tal, os timbres postos em jogo devem portar suficiente grau de dessemelhança entre si.

Um exemplo ilustrativo de uso proficiente dessa técnica é a orquestração de Liszt, quando comparada àquela de seu contemporâneo Wagner. Contrapondo-se à predileção deste por grandiloquentes emaranhados sonoros, o estilo de Liszt se afigura como um gesto de triagem que leva as combinações timbrísticas um passo adiante rumo à separação. Ao destacar a concentração, a clareza e a atribuição de funções nítidas a cada grupo timbrístico, Carse (1964 [1925]) registra os indícios sintomáticos do estado tensivo de contiguidade.

O agrupamento de seus timbres é bem concentrado, de clareza excelente, porém óbvio em sua concepção. Sua inclinação a explorar todos os novos recursos é patente em todas suas partituras e é mais na textura diversificada de seu material musical do que na intenção que seus efeitos orquestrais se distinguem daqueles de Wagner. Cordas, madeiras e metais recebem funções claramente distintas. Os grupos são harmonicamente satisfatórios e bem mesclados e o livre uso e poder do uníssono de metais contrapondo formações de cordas é ostensivamente apreciado. (Carse, 1964 [1925],p. 282 , tradução nossa ${ }^{\text {lxv }}$ )

Nesse ponto, gostaríamos de dar especial ênfase ao contrapeso entre metais em uníssono e cordas apontado em Liszt. Esse é um emblemático caso em que a contiguidade vem realçar a identidade individual dos timbres justapostos. Avizinhar timbres distintos para reafirmar sua individualidade é uma ideia que pode soar, em princípio, contraintuitiva. No entanto, é precisamente a aproximação - movimento fundamental instaurador da contiguidade - que traz à tona o contraste entre os diferentes. 
Em universo estético bem distinto, esse efeito de realce recíproco e contraste se deixa reconhecer também nas adjunções timbrísticas postas em cena por toda sorte de parcerias e participações especiais, como ocorre com Caetano Veloso e Gilberto Gil (2015), Chico Buarque e Caetano Veloso (1972) e a regravação de "O que é que a Baiana tem" com Caetano Veloso, Chico Buarque e Gilberto Gil em 2014 - só para ficar com alguns exemplos mais emblemáticos. Essa mesma técnica está por trás do efeito cômico na justaposição dos timbres de Chico Buarque e dos integrantes do grupo humorístico Os Trapalhões na regravação da canção "Meu caro Barão" que integra o disco "Saltimbancos trapalhões" (1981). O que essas colagens timbrísticas fazem é justapor timbres idiossincráticos para criar algo como um efeito-surpresa no ouvinte.

Retornando ao terreno propriamente semiótico da reflexão, esse efeito de saliência decorrente da adjunção de elementos díspares é bem sintetizado por Zilberberg (2011a) quando recupera a concepção de poesia surrealista de A. Breton: "A poesia 'deve tender cada vez mais a exercer seu poder inigualável, único, que é fazer aparecer a unicidade concreta de dois termos colocados em relação e comunicar a cada um deles, quaisquer que sejam, um vigor que lhes faltava quando eram tomados isoladamente'." (Zilberberg, $2011 a$,p. 22, grifos nossos, tradução nossa $\left.{ }^{\text {lxvi }}\right)^{27}$ Em um exercício de meta-reflexão teórica, é possível destrinchar o trecho do próprio autor para depreender daí uma correlação diretamente proporcional: quanto maior a proximidade dos termos, mais tônica sua "unicidade concreta". A aproximação de elementos distintos restabelece e recrudesce o brilho de sua identidade própria, antes deficitário ("um vigor que lhe faltava") em função de sua proximidade mínima ("tomados isoladamente").

Também não deve passar despercebida a compatibilidade da noção de "unicidade" com a função de identificação frequentemente atribuída ao timbre. ${ }^{28}$ Se é verdade que a contiguidade realça o caráter único dos elementos, então as contiguidades timbrísticas manifestarão, em superfície, o grau de afinidade entre a identidade profunda de suas componentes. Para dizer em outras palavras, pode-se trazer à tona as relações de maior ou menor similitude entre timbres fazendo-os avizinhar-se.

Embora trivial, esse raciocínio traz consigo consequências não-negligenciáveis para entender a compatibilização intertimbrística e seus efeitos de sentido. Para que o estado de contiguidade se mantenha estável e não acabe resvalando inadvertidamente em mescla ou mesmo em fusão, é preciso que os timbres preservem certa margem diferencial entre si. Isso significa que o grau de mistura requerido para uma contiguidade bem-formada precisa ser cuidadosamente comedido, refreando qualquer excesso que porventura desencadeie uma assimilação e consequente apagamento parcial das identidades particulares dos timbres

\footnotetext{
${ }^{27} \mathrm{~A}$ propósito, é essa estratégia de adjunção de elementos figurativos discrepantes que está, aliás, na base da poética surrealista de pintores como René Magritte.

${ }^{28}$ Cf. Cap. 2.
} 
componentes. $^{29}$ A justaposição das paletas timbrísticas exige do sujeito um apurado conhecimento técnico do instrumentário para atingir esse equilíbrio dinâmico de forças agregadoras (mistura) e desagregadoras (triagem) - com parcial vantagem dessas últimas no caso da contiguidade. É o que mostra a seguinte passagem acerca da orquestração italiana:

Tanto Bellini quanto Donizetti estavam prontos para se apropriar das vantagens melódicas e harmônicas das trompas e trompetes valvulados e fazer bom uso do naipe de madeiras não-misturado com o timbre de cordas. Ambos afastaram a inevitável monotonia de combinar cordas, madeiras e trompas com demasiada constância e entenderam plenamente o valor de permitir que as cores primárias da orquestra sejam escutadas separadamente como realce umas das outras. (Carse, 1964 [1925] ,p. 251, tradução nossa lxvii $)$

Um pequeno detalhe nesse trecho justifica categorizar tal estilo orquestral como contiguidade. A única coisa que se impõe contra o domínio pleno da força da triagem, implicada no gesto de separação das cores orquestrais, é a função de realce que aparece assinalada nas palavras finais da passagem em questão. Desemaranhando os timbres de suas mesclas, o gesto de separação não chega porém a se consumar integralmente. Ao invés disso, ele conserva ainda as cores timbrísticas em adjacência, preservando assim o efeito de contraste resultante dessa justaposição. Para obter esse resultado com sucesso, é preciso que a ação da triagem seja dosada na medida exata, uma vez que a separação absoluta apartaria por completo os timbres e acabaria, com isso, inibindo a aproximação necessária para esse tipo de efeito.

Nessa passagem, é proveitoso notar também como o estado de contiguidade é apresentado como uma solução criativa para atenuar o uso excessivo de misturas timbrísticas. Isso se deixa ver com especial clareza na avaliação depreciativa implícita na "monotonia" ocasionada pela "demasiada constância" das misturas entre cordas, madeiras e trompas. Outro indício de tal valoração negativa é a ideia de "permissão"30 dos timbres para soar não-misturados como se, até então, eles estivessem forçosamente subordinados às mesclas e fusões.

Ainda a respeito desse excerto, não pode passar despercebida a ênfase no excessivo uso da mistura, sintetizada na expressão "demasiada constância"31. O que está sendo negativamente avaliado aqui é menos a mistura propriamente dita do que o abuso desse recurso. Quando reivindica uma moderação do uso julgado excessivo da mistura, o

\footnotetext{
${ }^{29}$ Cf. subseção 4.2 .2 .

${ }^{30}$ Allowing no original em inglês

${ }^{31}$ Too constantly combining no original em inglês
} 
autor deixa entrever os mecanismos semióticos e tensivos que subjazem a esse tipo de posicionamento valorativo. Nos termos de Zilberberg (2011b), esse gesto de atenuação pode ser cifrado nos operadores elementares "menos mais", que viriam restabelecer o desejado equilíbrio entre triagem e mistura.

Esse controle da ação potencialmente excessiva da mistura se encontra aliás na descrição do estilo orquestral de Rossini. Seguindo Carse (1964 [1925]), esse compositor preza pela preservação das cores timbrísticas individuais, embora justapostas umas às outras. Como pano de fundo, reconhece-se a mesma configuração em contiguidade, que tolera as misturas de timbres contanto que sua fisionomia particular não seja transfigurada por tal adjunção.

[...] Ele [Rossini] tomou a iniciativa em manter claramente diferenciadas as cores da orquestra puras e elementares e, em certa medida, contrariou uma tendência à monotonia, causada pelo emprego excessivamente constante de diversos tipos de timbres em combinações de cores neutras e não-características. As partes solo de Rossini se destacam fortemente contra os fundos harmônicos de seus acompanhamentos. A clara dicção das partes melódicas de sopros não é obliterada pelo alicerce harmônico em vozes de timbres demasiadamente relacionados; a ornamentação contrapontística não interfere nas funções nem das partes melódicas, nem das partes de acompanhamento, e nem uma delas perde sua individualidade como resultado de um excesso de mescla ou entrelançamento de cores. (Carse, 1964 [1925], p. 240, tradução nossa lxviii)

Nesse trecho, não deve passar despercebido o interessante recurso à negação para descrever o estado de contiguidade. Ao invés de apenas afirmar a ação da triagem, o autor vai paralelamente negando a mistura, à qual atribui certa valoração depreciativa.

Em um primeiro momento, a negação se manifesta de maneira apenas implícita quando o autor aponta que Rossini "contraria" o emprego excessivo de misturas. É preciso sublinhar aqui como, segundo o autor, a profusão desmesurada dos tipos timbrísticos postos em mistura pode se degenerar em uma massa de "cores neutras e não-características". Do ponto de vista semiótico, essa indistinção pode ser lida como uma rarefação extrema do grau de densidade figurativa investida no timbre. ${ }^{32}$ Em um habilidoso movimento de negação da negação, o autor coloca Rossini no polo oposto, advogando pela preservação das peculiaridades características de cada timbre componente.

Em seguida, vê-se novamente o mesmo movimento de negação da misturas, dessa vez focado no destaque nítido recebido pelas melodias de sopros, que devem permanecer

\footnotetext{
${ }^{32}$ Cf. Cap. 2.
} 
impermeáveis aos timbres do acompanhamento harmônico ${ }^{33}$. Ainda nesse trecho específico, há também outra evidência que não pode passar despercebida. Ao apontar o iminente risco de obliteração trazido por timbres "demasiadamente relacionados"34, Carse (1964 [1925]) fornece mais uma evidência da relação direta entre o potencial de miscibilidade entre timbres e seu grau de semelhança mútua. ${ }^{35}$ Essa correlação foi absorvida pela linguagem orquestral contemporânea e consta mesmo nos manuais introdutórios mais acessíveis a amplo público: "Como um princípio geral, timbres que se mesclam bem em acordes apresentam pouco ou nenhum contraste quando escutados em sucessão; timbres que não se mesclam bem em acordes geram contrastes mais fortes." (Belkin, 2001, tradução nossalxix).

Se, tais formulações parecem pacíficas nos abstratos planos da teorização - como o é a investigação semiótica - a experiência concreta da práxis orquestral não se deixa limitar por tais fronteiras imaginárias e persegue, a seu próprio modo, os meios de instaurar contiguidades mesmo entre timbres demasiadamente semelhantes para tal. Um dos expedientes empregados para obter esse efeito é a mera disjunção espacial dos instrumentos. Para que a adjunção de timbres afins não se transmute em uma mescla indesejada, pode-se simplesmente posicioná-los o mais distante possível, visando dissimilar essas vozes. É o que recomenda Harnoncourt (1982) na seguinte passagem sobre o uso de cravos e pianos na formação em concertino.

A disposição separada do concertino (o grupo solista de um concerto) e da orquestra era usada por toda parte, a fim de tornar claro o diálogo ou esse efeito de eco. A esse respeito, coloca-se um problema particular no caso dos concertos para muitos cravos ou pianos. Hoje em dia, estes são dispostos mais frequentemente de tal maneira que o diálogo entre os instrumentos desejado pelo compositor passa despercebido, pois eles são colocados o mais próximo possível um dos outros. Assim, obtém-se mais a sonoridade de um cravo ou piano único, reforçado, e não aquela de numerosos instrumentos que falam entre si. Para criar as condições ideais, seria necessário tentar dispor os instrumentos o mais longe possível uns dos outros, para chegar em um resultado ótimo na separação do som, sem arriscar contudo o indispensável arranjo do conjunto. (Harnoncourt, 1982 , p. 117, tradução $\left.\operatorname{nossa}^{\operatorname{lxx}}\right)$

O risco de fusão timbrística vem assinalado de maneira explícita na quarta frase do trecho em questão. A contraposição entre "um cravo ou piano único, reforçado" e "numerosos instrumentos que falam entre si" manifesta claramente a oposição uno vs.

\footnotetext{
${ }^{33}$ Not blurred no original em inglês

${ }^{34}$ Too closely related no original em inglês

${ }^{35}$ Cf. Cap.5.5 p.201.
} 
múltiplo, que subjaz à dimensão da extensidade no esquematismo tensivo (Zilberberg, 2004, 2006b, 2011a,b). Especificamente no caso comentado acima, a similaridade dos timbres postos em jogo traz consigo certa propensão à assimilação mútua, o que pode comprometer o efeito de justaposição de vozes. Esse excerto testemunha ainda como a contiguidade pode ser obtida (e, consequentemente, também subvertida) por expedientes posteriores ao momento da composição. Isso mostra como as categorias semióticas oferecidas pela sintaxe extensiva não se limitam a esquadrinhar combinações timbrísticas cifradas em estado latente na partitura, mas se expandem a toda a gama de impressões sonoras possíveis nos diferentes momentos de composição, arranjo e execução/interpretação.

O caso em tela mostrou uma das possíveis interferências entre a sintaxe extensiva do timbre e a macroforma musical. Para que o diálogo entre concertino e ripieno, típico do concerto grosso, se afigure bem-formado, é forçoso que os timbres sejam empregados em estado de contiguidade. De mesma natureza é também a relação entre os timbres de uma melodia acompanhada, como se pode entrever na seguinte passagem:

A orquestração dos compositores do início do século XIX demonstra ostensivo apreço pela importância da nitidez ao lidar com as cores da orquestra. O som de cada instrumento pode ser escutado em seu estado nativo bem como em adjunção com outros timbres; partes solo são acompanhadas cuidadosamente por outras cujo timbre não subtrai nem atenua a individualidade do instrumento solo e os vários grupos consistindo de instrumentos de timbres relacionados são contrastados livremente, bem como combinados uns com os outros. Orquestração monocromática ou de cores neutras, resultado de combinações excessivamente constantes entre cordas, madeiras e trompas, foi uma decorrência posterior pela qual os compositores alemães foram amplamente responsáveis. (Carse, 1964 [1925], p. 230, grifos nossos, tradução $\left.\operatorname{nossa}^{\mathrm{lxxi}}\right)$

Apresentadas aqui como valores positivos, as noções de nitidez, clareza e adjunção das cores orquestrais consubstanciam de maneira clara o estágio de contiguidade. Ademais, os trechos colocados em destaque revelam um processo velado de restabelecimento, uma operação tensiva de "menos menos" que denega a subtração dos traços fisionômicos particulares de cada timbre. Esse gesto de preservação de singularidades timbrísticas é sintoma da sempre presente ameaça de uma indistinção indesejável, concretizada nesse excerto pela "orquestração monocromática" composta por "cores neutras".

Nesse ponto, o engenhoso recurso às metáforas visuais ilustra de maneira quase didática o resultado do excesso de similitude dos timbres justapostos. Empregada aqui apenas pela licença poética, a ideia de neutralidade das "cores" orquestrais insinua como, 
nesse caso em particular, a mistura de semelhantes resulta trivial, inespecífica e uniforme, como o atesta a ideia de unidade implicada no prefixo "mono-" (em "orquestração monocromática"). Essa constatação explicita um elo direto com o grau de densidade figurativa investida no timbre. ${ }^{36}$ Ocupar o estado tensivo de contiguidade se mostra então como uma solução eficaz para deter a ação da mistura que, especificamente nesse caso, teria como consequência uma indesejada pasteurização timbrística.

Disso não se deve presumir, porém, que a contiguidade seja sempre apenas um expediente provisório para frontear o ímpeto da mistura. Ao contrário, ela se deixa reconhecer em toda sorte de duplicidades e congeminações timbrísticas. Não raro, o efeito estético objetivado pelo arranjo e pela orquestração é exatamente essa dualidade. Para obter esse resultado, não basta no entanto apenas acoplar dois timbres escolhidos a esmo, nem mesmo bipartir timbragens distintas aqui e ali de maneira equânime. Em boa parte dos casos, o equilíbrio dinâmico característico da contiguidade exige do sujeito uma profunda intimidade com as incongruências latentes entre os timbres e a melhor maneira de compensá-las. Em situações como essa, uma contiguidade balanceada demandará, portanto, uma dosagem desigual entre os timbres componentes. Um exemplo disso pode ser encontrado no seguinte comentário de Carse (1964 [1925]) acerca da orquestração de Berlioz.

\begin{abstract}
Novamente, Berlioz não tinha ilusões com a potência das madeiras frente à retumbante e plena grandiloquência do material [sonoro] nas cordas. Se necessário, ele concentrava todo o naipe de madeiras em oitavas em uma parte, de modo que material independente ou essencial deveria se destacar claramente e abrir seu caminho pela espessa muralha do som de cordas. (Carse, 1964 [1925], p. 260, tradução nossa lxxii $)$
\end{abstract}

Conforme apontado anteriormente, o excerto destaca como a desproporção inerente aos timbres de cordas e de madeiras demanda certa compensação para resultar em um agregado sonoro congruente. Nesse cenário específico, tal contrapeso timbrístico é feito agrupando, de um lado, todos os timbres de madeiras com o intuito de equiparar o poder sonoro das cordas soando sozinhas do outro lado. Uma passagem breve como essa nos permite reconhecer, mesmo em proporções reduzidas, a ação simultânea das forças de triagem e mistura que regem a sintaxe extensiva. A patente potência sonora das cordas lhes permite competir por si só com todas as demais madeiras, que se veem obrigadas a se imiscuir para gerar, em um plano global, a contiguidade visada. O efeito sonoro global resulta de um intrincado jogo de triagens e misturas que, incidindo umas sobre as outras, (co)operam em dominâncias dinâmicas e parciais.

\footnotetext{
${ }^{36}$ Cf. Cap. 2.
} 
Ao contrário da mescla - seu sub-contrário correlato no domínio da mistura a contiguidade tende a ir acentuando diferenças e delineando limites entre os timbres adjuntos. Sob ação da triagem, a contiguidade retém timbres em adjacência sem, no entanto, permitir que se apartem de fato. Nesse aspecto, a orquestração de Saint-Saëns parece pôr em cena o último ponto de coalescência timbrística antes de seu desligamento total no estado tensivo de separação.

A segregação da função de cada instrumento ou grupo de instrumentos em qualquer momento particular, a distinção clara entre os timbres, o espaçamento das mudanças de timbres, a habilidade em usar pouquíssimas notas com eficiência e em evitar combinaçôes nas quais cada timbre cancela a individualidade de outro; tudo isso dá variedade, clareza e equilíbrio para a obra de Saint-Saëns, e coloca seu trabalho no extremo oposto de Brahms e muitos de seus contemporâneos alemães. (Carse, 1964 [1925], p. 300, grifos nossos, tradução nossa lxxiii )

No excerto em questão, vê-se novamente o uso de uma metáfora visual-espacial, sugerida na ideia de "espaçamento" entre timbres, para designar a força da triagem apartando progressivamente os timbres postos em jogo. O estado de contiguidade se deixa reconhecer também no gesto, destacado por nós na passagem acima, de rechaçar a sempre iminente neutralização da "individualidade" dos timbres. Essa operação de negação da negação das identidades timbrísticas particulares assinala o derradeiro momento anterior à afirmação positiva de suas diferenças, conforme predito pela sintaxe elementar do quadrado semiótico (cf. Greimas, 1975b). Como se pode constatar, o caso de Saint-Saëns é peculiar pois demarca exatamente o ponto de virada em que o equilíbrio estável da contiguidade timbrística se transmuta no estado tensivo de separação.

\subsubsection{Separação - a triagem absoluta}

Configurando o estágio de separação (Zilberberg, 2004), o domínio absoluto da triagem isola um timbre em particular, que assume o primeiro plano frente aos demais. Nesse cenário, rege entre os timbres algo como uma incompatibilidade mútua a impedir o menor gesto de assimilação colorística. Tudo se passa como se os timbres em questão se fizessem inconciliáveis uns aos outros em uma espécie de rivalidade sonora, na qual toda tentativa de mistura resulta em choques, fricções e incongruências esteticamente mal-formadas.

Nesse sentido, o exemplo mais bem acabado da ação da triagem são as composições a capella. Nelas, a ausência de outras colorações timbrísticas cumprindo a função de 
acompanhamento abrem espaço para o domínio pleno de um e somente um timbre. Configura também o estado de separação todas as formações instrumentais monotimbrísticas, como é o caso das assim chamadas "orquestras de flautas", "orquestras de violoncelos", "orquestras de guitarras" entre outras congêneres. ${ }^{37}$ Seja no domínio da música erudita ou da música popular, a máxima uniformização em todo o espectro da tessitura demonstra de maneira concreta os efeitos individualizantes do estado de separação, perceptível nesse caso na exclusão de todas as demais timbragens dessemelhantes e mais distantes de um dado epicentro timbrístico. Aqui, nota-se mais uma vez a sobredeterminação mútua entre triagem e mistura: o destaque dos eleitos acarreta forçosamente a mistura dos preteridos.

Se, para alguns timbres, essa uniformização parece uma inovação criativa, para outros, ela se constituiu e se impôs desde longa data. É o que aconteceu, por exemplo, precocemente com o naipe de cordas, conforme testemunhado pelo seguinte excerto acerca da manufatura de gambas e violinos e sua passagem à família de cordas como atualmente conhecida:

Desde o começo do século XVI, a gamba fora construída em coros, isto é, fabricava-se instrumentos de tamanhos diferentes para o soprano, o contralto, o tenor e o baixo. Com tais formações, executava-se essencialmente obras vocais, que eram adaptadas aos instrumentos por meio de uma ornamentação apropriada. [...] Nessa época, o violino não figurava ainda entre os instrumentos respeitáveis e servia em primeiro lugar à música de dança improvisada. (Harnoncourt, 1982 , p. 141 , tradução nossa lxxiv )

O progressivo aumento de coesão da orquestra ocidental se deu às custas de certa homogeneização timbrística e dissimilação dos demais naipes. Nesse percurso, o processo de triagem se deixa flagrar na uniformização das famílias instrumentais. Na passagem abaixo, essa exclusão é negativamente valorizada, como indicado pelo uso do termo "empobrecimento", em benefício de uma euforia das misturas na instrumentação da orquestra barroca:

No conjunto, observa-se um empobrecimento da paleta sonora, pois na orquestra moderna, todos os instrumentos tendem a uma sonoridade arredondada, pobre em harmônicos agudos ao passo que, na orquestra barroca, a diferenciação dos grupos instrumentais era mais marcada e portanto mais rica. (Harnoncourt, 1982 , p. 140, tradução nossa ${ }^{\text {lxxv }}$ )

\footnotetext{
${ }^{37}$ Mesmo cientes de que qualquer tentativa de enumeração aqui é vã, recomendaríamos àqueles menos familiarizados com esse repertório a audição de grupos como Orquestra Paulistana de Viola Caipira, Sujeito a Guincho, Orquestra Sanfônica 'Seu Dominguinhos', Orquestra Portuguesa de Saxofones entre outros.
} 
Certos timbres tendem a ser empregados preferencialmente no primeiro plano das melodias solistas, o que, no limite, desemboca no estágio tensivo de separação. No entanto, esses papéis não são estáticos e irrevogáveis. Ao contrário, a história da orquestração põe em cena todas as vicissitudes e os meandros dessas transfigurações, como o mostra o seguinte excerto:

Uma característica muito importante no crescimento da orquestração desse período se deu ao uso ampliado do violoncelo como uma voz independente. De mero instrumento baixo em um primeiro momento, o violoncelo se tornou um instrumento tenor ocasional por volta do final do século XVIII, e agora na orquestra como um melodista pleno o qual, em acréscimo às suas funções anteriores, estava pronto e apto para assumir a responsabilidade de apresentar material melódico na íntegra, com ou sem o auxílio de outros instrumentos. (Carse, 1964 [1925], p. 225-226, tradução nossa ${ }^{\text {lxxvi }}$ )

A passagem em questão aborda a transmutação do violoncelo de mero suporte harmônico para instrumento melodista. O ganho de autonomia melódica põe em cena um processo de triagem até consumar a separação, uma vez que esse timbre não está mais subordinado ao anonimato das misturas. Composições em melodia acompanhada configuram exemplos frequentes do estado de separação, embora menos perfeitos do que aquele colocado pelas composições a capella. Ainda que intercalando contiguidades, peças construídas com essa textura se baseiam em ampla medida no estado de separação. No limite, toda melodia acompanhada acaba colateralmente acarretando uma separação.

Tal ganho de autonomia melódica está relacionado em larga medida à prototipização do timbre e sua relação de compatibilização entre revestimento timbrístico e substrato linguístico-melódico. ${ }^{38}$ A maior independência melódica-cromática de um timbre diz respeito sobretudo aos padrões previstos pela práxis enunciativa vigente. Em outros termos, é isso que está em jogo quando musicistas se referem à "linguagem" de um instrumento. ${ }^{39}$ Para uma investigação semiótica calcada sobre o princípio de imanência, importa menos o instrumento musical propriamente dito do que a cristalização discursiva de sua fisionomia timbrística.

Esse grau de particularidade e idiossincrasia pode ser mensurado pelo conceito semiótico de densidade figurativa. ${ }^{40}$ No excerto abaixo, essas duas variáveis são associadas de maneira direta pelo autor ao colocar que a particularidade do timbre dos instrumentos

\footnotetext{
${ }^{38}$ Cf. Seção 5.4.3.

${ }^{39}$ Cf. Seção 5.3.3.

${ }^{40}$ Cf. Cap. 2.
} 
barrocos motivou sua atribuição preferencial para as linhas melódicas solistas. Sob essa perspectiva, tudo se passa como se o próprio caráter idiossincrático desses timbres os impelisse ao estado de separação inerente aos solos.

Esses instrumentos [oboé d'amore, oboé da caccia], em razão de seus timbres particulares, eram antes de tudo empregados para os solos, mas às vezes dobravam igualmente as vozes intermediárias da orquestra de cordas. A flauta transversal é um instrumento solista típico e só em poucas obras da época barroca ela é empregada exclusivamente como instrumento de tutti. (Harnoncourt, 1982 , p. 156, grifos nossos, tradução nossa lxxvii )

Também é digna de nota aqui certa ambivalência tensiva do timbre de flauta. Embora passível de contrair misturas, ela demonstra predominante tendência à triagem em sua notória propensão a assumir solos. É interessante assinalar esse traço em termos de prototipia para deixar claro que não se trata de atribuir categoricamente a estes ou aqueles timbres um rótulo de triagem ou de mistura, mas sim de apreender seus usos considerados mais conformes às orientações estéticas vigentes em determinada comunidade de sentido. ${ }^{41}$ A despeito de certa tendência à separação, semelhante caso de ambivalência se dá também na emergência dos sopros no período barroco. Embora não apresente uma amostra tão nítida do estado tensivo de separação, a passagem seguinte dá a ver a ação da triagem trazendo para si registros timbrísticos que, de outro modo, poderiam resvalar no anonimato das misturas.

Os instrumentos de sopro da época barroca eram construídos de modo que tivesse, de um lado, uma sonoridade claramente reconhecível em solo e, de outro lado, que pudessem facilmente se unir a outros instrumentos de mesma tessitura em uma mescla sonora nova. O exemplo mais característico disso é o oboé (a aliança do oboé e do violino constitui de fato a essência sonora da orquestra barroca). (Harnoncourt, 1982 , p. 155 , tradução nossa lxxviii $)$

O estado de separação se faz especialmente relevante no ponto em que consagra a emancipação completa de timbres mais recentemente incorporados em uma formação instrumental dada. Esse foi, por exemplo, o caso dos timbres de metais no corpo da orquestra. Ao menos em comparação com o naipe de cordas e com algumas madeiras, os metais foram mais tardiamente introduzidos e incrementados. Seu emprego de forma

\footnotetext{
${ }^{41}$ Cf. Cap. 2, seção 2.5.
} 
autônoma é testemunhado, por exemplo, na instrumentação do compositor alemão Meyerbeer: "Meyerbeer em particular não hesitava em apresentar timbres de metais imaculados com uma riqueza até então inédita, o que se deu simplesmente devido à livre escolha de notas à sua disposição nas partes agudas de metais." (Carse, 1964 [1925] , p. 249, tradução $\operatorname{nossa}^{\text {lxxix }}$ )

Em proporções reduzidas, o excerto em questão apresenta como se dá esse jogo de oposições estilísticas no interior de um espaço discursivo. Vê-se, assim, desenhar dois vetores de orientações opostas quanto à promoção das misturas ou triagens timbrísticas. Se, por um lado, a mistura de timbres propicia efeitos estéticos bem apreciados, por outro lado, seu emprego excessivo parece ter suscitado um contramovimento, como se conclamasse por um restabelecimento da pureza e das feições sonoras originais. É o que demonstra a seguinte passagem acerca da instrumentação do compositor russo M. Glinka:

Os três principais grupos instrumentais eram, para Glinka, corpos tão distintos e autônomos cujas funções deveriam ser claramente separadas, e cujas cores deveriam ser usadas em alto contraste umas com as outras, ao invés de três partes de um todo cujas características individuais deveriam ser modificadas e nuançadas tanto quanto possível por meio de combinação, mescla e mistura de timbres. (Carse, 1964 [1925] , p. 266, tradução nossa ${ }^{\mathrm{lxxx}}$ )

O excerto acima contrapõe de maneira quase didática dois cenários diametralmente opostos. Em um dos lados, encontramos a máxima dissimilação e separação dos naipes instrumentais em "alto contraste" conforme praticada por Glinka. No outro, antagonizalhe um estilo orquestral caracterizado por toda sorte de gradientes e nuances a matizar a sonoridade geral da orquestra.

Até o momento, procuramos demonstrar como as combinações timbrísticas efetuadas pela práxis orquestral e instrumental se deixam categorizar pelos estágios de fusão, mescla, contiguidade e separação. Por motivos de clareza expositiva, apresentamos os dados extraídos de nosso material de análise da maneira mais compartimentada possível com o intuito de mostrar ostensivamente exemplos prototípicos de cada caso em questão. Acerca desses, resta ainda pronunciar-nos sobre seu caráter dinâmico. 


\subsection{Interpretação e debate}

\subsubsection{Dialéticas da triagem e da mistura e práticas de rearranjo musical}

Mais do que categorizações estanques e impermeáveis, os estágios de separação, contiguidade, mescla e fusão representam antes pontos salientes de um processo contínuo de triagem-mistura, sendo estes vetores opostos, mutuamente dependentes e constituintes da dimensão da extensidade (Zilberberg, 2004, 2011b). A abordagem semiótica tal como delineada aqui não autoriza nenhum analista a tomar isoladamente timbres e etiquetá-los como "pertencentes" à triagem ou à mistura. Um timbre que, a princípio, tende a se isolar por força da triagem pode, de repente, se render à mistura e se deixar assimilar docilmente a um matiz timbrístico particular. Raciocinando na direção inversa, pode-se conceber também que um timbre em aparência mais afeito às misturas se revele, contrariando todas as expectativas, resistente a uma dada combinação específica.

Uma tal abordagem revela um inesperado caráter rítmico de fundo na medida em que contempla o timbre em seus agrupamentos e combinações, e não como unidade isolada. Esse ponto está em plena consonância com Zilberberg (2004) quando, resgatando Hjelmslev (1991, 2006 [1943]), declara que "a relação é afirmada como invariante e como condição da comparação, e os termos, como variáveis, [...]" (2004, p. 79). Vê-se, assim, como as triagens e misturas de timbres manifestam de maneira direta o princípio glossemático de prevalência da relação sobre os termos.

Em suma, trata-se aqui de organizar um sistema autônomo e geral de todas as combinatórias intertimbrísticas possíveis, cujas realizações concretas serão determinadas caso a caso pelas orientações estéticas vigentes em cada contexto sociocultural e histórico. Procedendo dessa forma, a abordagem semiótica dá conta não apenas das técnicas de arranjo e orquestração já atestadas ao longo da história da música, mas também daquelas que ainda aguardam ser exploradas. Assim, coloca-se em prática a diretriz epistemológica de que uma teoria verdadeiramente geral deve explicar não apenas os realizados, mas sim os realizáveis: "O linguista, como qualquer outro teórico, deve portanto ter a precaução de prever todas as possibilidades concebíveis, incluindo-se aqui aquelas que são ainda desconhecidas e as que não estão realizadas." (Hjelmslev, 2006 [1943] , p. 20).

Aplicado à orquestração da assim chamada música ocidental erudita, esse ferramental analítico pode ser empregado da mesma maneira para o entendimento de outros universos estéticos. Se, na orquestra europeia, os naipes de cordas se afiguram como exemplo mais bem acabado de mescla e fusão, nada nos impede de declarar o mesmo para a feliz comunhão de trompetes, pistões, bombardinos, saxofones e trombones que 
consagrou a formação das big bands americanas. Mais abaixo da linha do equador, não é em nada diferente o caso da emergência e da estabilização dos regionais de choro que, por uma filtragem paulatina, foram agregando e temperando diferentes timbragens até se consolidar na formação que conhecemos atualmente (Cazes, 1998, p. 47). Os exemplos poderiam se multiplicar ao infinito. Cabe a cada comunidade de sentido arbitrar sobre a razoabilidade das misturas e/ou triagens timbrísticas nela praticadas.

A construção da paleta sonora se faz sempre pela ação simultânea e ambivalente da triagem e da mistura, que vão mesclando uns timbres enquanto subrepticiamente excluem outros. A olhos leigos, dão-se mais facilmente a perceber os timbres que de fato marcam presença em um dado arranjo. É preciso, todavia, observar também esse fenômeno em negativo, prestando atenção aos timbres em ausência. É assim que triagem e mistura jogam, por baixo da mesa, um jogo dinâmico e velado. Seu caso mais emblemático é o do naipe de cordas que, atingindo um grau superlativo de fusão interna, acabou por se apartar dos demais matizes timbrísticos. Curiosamente, o recrudescimento paroxístico da mistura acaba por desembocar em uma triagem, quando observada a relação entre famílias de timbres.

Essa delicada dinâmica entre triagem e mistura é um desafio permanente para todo aquele que se dedica à prática do arranjo e da instrumentação. Para além das dificuldades impostas pela transposição da linguagem de um instrumento para outra, o equilíbrio sonoro do rearranjo depende sobretudo da compatibilização recíproca entre os integrantes da nova formação instrumental. É regido pela triagem todo (re)arranjo que vem reduzir e uniformizar a paleta timbrística empregada, excluindo e equiparando todos os demais timbres à revelia de seu maior ou menor grau de semelhança mútua. Esse é prototipicamente o caso de composições para instrumento solo, de arranjos a capella e das transcrições (para piano, violão, órgão etc.) de peças concebidas originalmente para grandes formações, como é o notório caso das transcrições de Franz Liszt. Em âmbito brasileiro, é digno de nota o estilo minimalista "voz-e-violão" consagrado por João Gilberto, que sintetiza o movimento mais amplo de depuração designado por Tatit (2004b , p. 91-110; 177-200) como "gesto bossa-nova". Ainda em contexto nacional, é particularmente ilustrativo o episódio da passeata contra a guitarra elétrica em 1967, emblemático gesto de preservação da brasilidade pura contra uma suposta profanação timbrística americanizante (Tatit, $2004 b$, p. 210). Esse rol não pode ser dado por completo sem mencionar ainda toda sorte de "orquestras" e ensembles constituídos por um único tipo de instrumento. Por fim, deve-se incluir aqui a cristalização do timbre de voz de intérpretes consagrados, que se alçam a primeiro plano por sobre um acompanhamento tido como menos distinto.

Indo na direção oposta, a mistura se deixa reconhecer em toda reescrita para 
orquestra de peças originalmente compostas para um único instrumento ou família de instrumentos. Nessa passagem, o rearranjador se vê forçado a redistribuir em diversos timbres diferentes material melódico e harmônico que, até então, vinha manifestado em um único registro timbrístico. ${ }^{42}$ No domínio da música erudita europeia, o caso mais emblemático é a orquestração consagrada por Ravel da peça Quadros de uma exposição, composta originalmente por Mussorgsky apenas para piano. Em outro campo estético sensivelmente distinto, encaixa-se aqui também aquilo que Tatit (2004b, p. 200-212) apresenta como "gesto tropicalizante" na história da canção brasileira, cujo representante mais notório é o álbum "Panis et circensis" (cf. Favaretto, 2007 [1979], p. 78 ss.). São também exemplos legítimos dessa operação de mistura os diversos álbuns que agregaram formações orquestrais a um conjunto originalmente menor. ${ }^{43}$ Já em outro domínio estético, não é outra a proposta de grupos como a Transversal Frevo Orquestra (2010) quando agrega um naipe de flautas transversais à formação instrumental do frevo ou as gravações do bandolinista brasileiro Aleh Ferreira (2010) quando agregam um quarteto de cordas à formação tradicional do regional de choro.

Se, por um lado, proliferam os registros timbrísticos passíveis de figurar no arranjo, por outro lado, essa apoteose sonora não se faz sem o ostracismo dos ruídos (cf. Wisnik, 1989), vocalizações animais entre tantas outras abjeções sonoras. Aqui, a triagem age unicamente para impedir a profanação sonora por um timbre negativamente valorizado. O eventual contraexemplo da música concreta, da acusmática, do ruidismo e da música experimentalista (cf. Russolo, 2003 [1913]) nada mais faria do que corroborar essa ideia, uma vez que tais movimentos estéticos tendem a evitar os timbres tidos por mais convencionais. No final de contas, a triagem apenas deslocou sua mira dos ruídos para as timbragens até então tidas por bem-formadas.

\subsubsection{Sintaxe extensiva e norma estética}

Nunca é demasiado advertir que tal dominância da triagem ou da mistura só se faz reconhecer nos arranjos a partir de uma perspectiva intertextual e interdiscursiva. É na relação com os demais textos circulantes em uma dada esfera cultural que estimamos o quantum de triagem e/ou de mistura timbrística em uma dada peça musical. Isso justifica em parte as dificuldades de aplicar essa abordagem a domínios culturais e estéticos menos

\footnotetext{
${ }^{42}$ A título de exemplo, cf. Pereira (2011, p. 259 ss.) para uma proposta concreta de rearranjo orquestral dos Choros 5 de Villa-Lobos.

${ }^{43}$ Cf. a título de exemplo álbuns de rock como "Moment of glory" (2001), gravado pela banda alemã Scorpions com a Orquestra Filarmônica de Berlim e "Metallica: S\&M" (1999), gravado pela banda homômima junto com a Orquestra Sinfônica de San Francisco. Destaquemos também o premiado "Os Saltimbancos Sinfônico", regravação do clássico de Chico Buarque e Sérgio Bardotti pela Orquestra Petrobrás Sinfônica do Rio de Janeiro (2016).
} 
familiares. Se não conseguimos aplicar impecavelmente triagens e misturas a um corpus etnomusicológico, é menos devido a uma limitação do ferramental analítico do que à nossa carência de referências intertextuais pertinentes.

O que exemplificamos aqui no âmbito das diferentes esferas culturais se aplica de igual maneira aos diferentes contextos históricos e sociais. Suas respectivas normas estéticas dominantes ditam quais combinações timbrísticas são consideradas conformes ao consenso estético em vigor e quais delas são consideradas desviantes. Nos termos próprios à semiótica tensiva, diríamos então que uma mistura e/ou triagem pode ser respectivamente implicativa ou concessiva (Zilberberg, 2012, p. 66 ss.).

Quando da ordem da implicação, a triagem e/ou mistura de timbres é vista como sensata, óbvia, esperada e até mesmo trivial. Confirmam-se expectativas, como tipicamente ocorre no regime do pervir (Zilberberg, 2011b). Aqui, as triagens implicativas agem eliminando os timbres discrepantes. Por sua vez, as misturas implicativas congregam os timbres semelhantes mais aptos à miscibilidade mútua e repatriando os excluídos. Assim as paletas timbrísticas herdadas já prontas da práxis enunciativa musical vão sendo reproduzidas, sem abrir espaço para qualquer intervenção inovadora. Encontra-se aí em pleno terreno do exercício (Zilberberg, 2011b).

Do outro lado, a concessão está na base das escolhas orquestrais e instrumentais tidas por inusitadas e contraintuitivas. Rompendo com as expectativas instauradas pela norma estética vigente, a mistura concessiva não se acanha em cometer a extravagância de mesclar timbres díspares entre si. De maneira semelhante, a triagem concessiva vem "separar os inseparáveis", dilatando sua margem diferencial até então considerada mínima. Para fazer jus às fórmulas-síntese caras a Zilberberg (2004), pode-se resumir esse movimento da seguinte maneira: apesar de "membro da família", um determinado timbre foi excluído do arranjo. ${ }^{44}$

Extraídas graças a essas operações da sintaxe extensiva, tais constatações fazem contraponto às ideias de Coelho (2007) quando semiotiza o arranjo em termos de modos de existência e de perfil temporal dos instrumentos selecionados. ${ }^{45}$ Os resultados levantados pela análise mostram que mesmo timbres de idêntico perfil temporal-aspectual ${ }^{46}$ apresentam diferentes graus de compatibilidade e de (i)miscibilidade mútua. Esse é mais um indício de como a seleção e a combinação de timbres não pode ser explicada unicamente em função de suas características morfológicas internas. Um olhar para o caráter "inter-" de suas relações revela nuanças mais refinadas.

\footnotetext{
${ }^{44}$ Aqui, estamos diante do gesto de proclamação da "contrariedade dos idênticos" (cf. p. 96).

${ }^{45}$ Cf. Cap. 1.

${ }^{46}$ Cf. Cap. 3.
} 


\subsubsection{Fenômenos análogos}

A abordagem do timbre via combinação e seleção se justifica pela recorrência consistente desse princípio em outros domínios semióticos, verbais e não-verbais. Nesses últimos, o domínio cromático consuma convenientemente a metáfora do timbre como "cor do som". Em sua Doutrina das Cores, J. W. Goethe (2013 [1810]) distribui o espectro cromático em um círculo, no qual os pontos diametralmente opostos se convocam e criam assim um equilíbrio dinâmico. Segundo o pensamento desse autor, é de mesma natureza a relação de totalidade complementar entre vermelho e verde, entre violeta e amarelo e entre azul e laranja (Goethe, 2013 [1810] , p. 95, §60). Dessa forma, o pensador alemão teoriza as combinações de cores e seus efeitos organizando-as em um sistema relacional que, diferenças epistemológicas à parte, demonstra semelhanças inesperadas com a abordagem estruturalista que só viria a nascer pelo menos dois séculos depois. ${ }^{47}$

No âmbito das linguagens verbais, a analogia mais evidente é a fonotática, área da fonologia que estuda "o conjunto de condições que determinam as sequências sonoras bem-formadas de uma língua" (Silva, 2017,p. 119). Essa autora aponta que, em português brasileiro, encontros consonantais na mesma sílaba devem necessariamente ser constituídos de uma consoante obstruinte seguida de uma consoante líquida. ${ }^{48}$ Vetado pelas regras fonotáticas do português brasileiro, um encontro consonantal como /spr/ é, porém, perfeitamente aceitável em uma língua como o alemão. Essa é apenas uma ilustração pontual de um vasto campo de estudos linguísticos dedicado a mapear o inventário de sequências sonoras possíveis e impossíveis para cada língua natural.

Para um estudo semiótico do timbre, o interesse dessa analogia é que a fonotática estabelece seu próprio jogo de regras combinatórias, à revelia de qualquer ancoragem ao plano do conteúdo. Os encadeamentos sonoros de segmentos e acentos se organizam sintagmaticamente em um sistema autônomo. A intuição de falante distingue sequências sonoras realizáveis (mas não necessariamente realizadas) na língua, como é o caso das assim chamadas pseudopalavras. ${ }^{49}$ Mutatis mutandis, esse é o mesmo princípio estruturante que

\footnotetext{
${ }^{47}$ Cf. Estay-Stange (2014b) para uma exaustiva revisão bibliográfica e histórica desse paradigma dos complementares nas artes plásticas, bem como sua contribuição para um modelo de análise transversal do sentido nas artes, contempladas aí também a poesia e a música.

${ }^{48}$ Alguns exemplos de encontros consonantais bem-formados em português figuram nas palavras: branco, prato, blusa, plástico, tranco, atlântico, drástico, classe, cratera, glândula, grande, flácido, fraco, livro etc. A sensibilidade linguística do leitor rapidamente intuirá aqui que certos padrões ocorrem mais raramente na língua (/vl/ e /dl/, por exemplo).

${ }^{49}$ Estudos da fonologia designam por "pseudopalavras" sequência de sons que "compõem um todo pronunciável, mas carente de significado" (Capovilla et al., 2006, p. 48). Embora bem-formados segundo as regras fonológicas de uma dada língua, tais encadeamentos fonêmicos não constituem nenhum item vocabular reconhecido como tal. Segundo Needle (2017,p. 3, tradução nossa $\left.{ }^{\text {lxxxi }}\right)$ : “Um objetivo central da fonologia é caracterizar as possíveis palavras das línguas individuais. Em qualquer língua, o léxico contém apenas uma parcela das formas fonologicamente possíveis. Todas as outras formas possíveis (porém sem significado) são pseudopalavras.”. Exemplos de pseudopalavras extraídos de Benevides (2017, p. 125)
} 
vislumbramos para as combinações e seleções de timbres.

Além da fonotática, outros domínios de análise linguística trazem ainda mais indícios da recorrência desse princípio. Essas mesmas regras de restrições e combinações operam também no campo do significado, nomeadamente na semântica lexical e na fraseologia da língua. Todo falante de português brasileiro reconhece certa impropriedade em construções como "eu bebi feijão" e "eu comi leite", uma vez que esses verbos exigem objetos conceptualizados respectivamente como líquidos e sólidos.

A violação dessas regras de seleção gera anomalias semânticas (Gomes \& Mendes, 2018 , p. 52). ${ }^{50}$ No exemplo em questão, intui-se sem dificuldades como a permuta de objetos gera as construções bem-formadas "eu bebi leite" e "eu comi feijão".

Uma coerção de mesma natureza está por trás também de combinações lexemáticas altamente estáveis, tais como as colocações (cf. Crystal, 1988, p. 51; Dubois, 2011 [1973] , p. 116), as expressões idiomáticas e os clichês. A intuição de qualquer falante de português brasileiro certamente reconhecerá como familiares colocações como "cometer um erro", "desperdiçar chances", "pleitear uma vaga" entre tantas outras. O mesmo se aplica também para idiomatismos cristalizados pelo uso como "dar a volta por cima", "estar por fora", "dar com os burros n'água" entre outros. No caso desses últimos, a combinação lexical se cristalizou a tal ponto que não é possível comutar os termos para criar novos sentidos. Em outras palavras, não se pode alterar o sentido da expressão idiomática "rodar a baiana" substituindo o verbo por um sinônimo qualquer ("girar" ou "virar", por exemplo) e somente a criatividade imprudente de um falante ousaria produzir uma expressão como "rodar a mineira", "rodar a paraibana", "rodar a carioca" ou outra variante assemelhada.

Essa mesma estabilidade de co-ocorrência que confere aos idiomatismos sua imutabilidade também estigmatiza negativamente os clichês, condenando-os a figurar entre os assim chamados "vícios de linguagem" das gramáticas escolares e dos manuais de redação. "Erro crasso", "grande maioria", "ideia brilhante": abundam os exemplos registrados em manuais de estilo jornalísticos, bem como as alternativas sugeridas para evitar tais combinações já desgastadas pelo constante abuso. É interessante notar como, inoperante no caso dos idiomatismos, a paráfrase por meio da sinonímia dissipa facilmente

para o Português Brasileiro são "casemi", "gazonar", "malanto", "dercali" entre outros. As pseudopalavras funcionam como "conchas vazias" de sons, aptas a ser eventualmente preenchidas com sentidos pela neologia.

${ }^{50}$ Tais combinações desviantes têm sido designadas pelo Groupe $\mu$ como alotopia e, em certos casos, chegam a assumir certo caráter retoricizante: "A figura [retórica] é, de fato, descritível como uma das modalidades possíveis da gestão dos desvios, o desvio não sendo nada além de uma violação das regras de combinação previstas pela grade [de expectativas] (a coexistência da pelagem e do bico no ornitorrinco constitui uma dessas violações, da mesma maneira que o enunciado 'o pneu X bebe o obstáculo', no qual constata-se a aparição de um substantivo não comportando o sema 'liquidez' atrás de um verbo selecionando o classema 'liquidez'). Damos a essa violação o nome de alotopia, [... ]." (Groupe $\mu, 2015$,p. 464, tradução nossa $\left.{ }^{\text {lxxxii }}\right)$. Cf. também Groupe $\mu$ (1970, 1977, 1992). 
a valoração negativa contraída pelo clichê sem descaracterizar seu sentido. Vislumbra-se aí um curioso paralelismo entre idiomatismos e clichês: nestes, uma combinação lexical específica é indesejável; naqueles, ela é não apenas desejável, mas também imperativa.

Embora ingênua em aparência, essa reflexão sobre a co-ocorrência de termos lexicais inspirou as primeiras reflexões de Greimas (1976 [1966],p. 93-97) ainda em Semântica Estrutural sobre a noção de isotopia. Tomando como exemplo o humor criado pela ambiguidade irresolúvel do termo toilettes ${ }^{51}$ em uma anedota espirituosa e pela ambiguidade sintática na sentença "o cão do comissário ladra", o autor mostra como o desencadeamento das diferentes isotopias decorre diretamente de uma combinação lexemática particular. ${ }^{52}$ Em ambos os casos, o efeito de humor se dá pela dupla leitura dos enunciados que, por sua vez, só resulta possível pelo encadeamento dos vocábulos em uma sequência específica. Essa mesma ideia de fundo permanece em formulações posteriores. A definição de percurso figurativo como encadeamento de figuras não deixa dúvidas quanto ao papel fundamental da combinação e da linearidade na construção da isotopia:

Esse encadeamento, fundamentado na associação das figuras - próprio de um universo cultural determinado - , é em parte livre e em parte obrigatório, na medida em que, lançada uma primeira figura, essa exige apenas algumas, com exclusão de outras. [...]: nesse caso, o desdobramento figurativo da sequência se encontrará afetado por elas; [...], de acordo sempre com a figura inicialmente escolhida. (Greimas \& Courtés, 2012 [1979], p. 213, grifos nossos)

Cumpre destacar como a figura inicial afunila o espectro de possibilidades das figuras subsequentes. Exemplifiquemos: a emergência de uma figura como "castelo" em um romance histórico induzirá o leitor a antever figuras afins, tais como "espada", "princesa", "cavaleiro" etc., enquanto outras figuras, como "computador", "forno micro-ondas", "automóvel" etc., poderão prejudicar a verossimilhança e destruir a ilusão referencial necessária para esse gênero literário. ${ }^{53}$ Da mesma maneira, no caso específico de nosso objeto de estudo, a ocorrência de um determinado timbre induz nossa expectativa de ouvinte na direção de uma certa paleta timbrística em detrimento de outras. Se, nos primeiros momentos da audição de uma peça musical, um timbre de violino se dá a reconhecer, nossos ouvidos ficarão imediatamente em guarda à espera de violoncelos, violas, contrabaixos, oboés, flautas, trompas, entre outros timbres co-partícipes de seu

\footnotetext{
${ }^{51} \mathrm{Na}$ língua francesa, esse substantivo pode significar tanto 'vestimentas' quanto 'sanitários'.

${ }^{52}$ Cf. Seção 3, p. 89.

${ }^{53}$ É oportuno assinalar que a combinação insólita de universos figurativos pode ensejar o nascimento de novos gêneros e orientações estéticas, como é o caso da ficção científica e da literatura steampunk.
} 
campo estético, ao passo que outros tenderão a escapar desse horizonte de expectativas. Gaitas de foles, ocarinas, bandolins, shakuhachis e berimbaus exemplificam apenas alguns dos inúmeros tipos timbrísticos improváveis nesse cenário, ainda que não absolutamente impossíveis.

Esse cálculo de previsibilidade quase intuitivo é um fazer-interpretativo (cf. Greimas \& Courtés, 2012 [1979] ,p. 271) efetuado pelo sujeito depende inelutavelmente de sua inserção em um dado universo estético. Conforme destacamos na passagem acima, o encadeamento de figuras é "próprio de um universo cultural determinado". Assim sendo, as combinações timbrísticas preferenciais e as incomuns são balizadas por sua colocação em discurso e pelo seu uso, e não por fatores de ordem estrutural (cf. Greimas, 1975b, p. 105 ss.).

\subsubsection{Sintaxe extensiva e especificação semântica intermediária}

As triagens e as misturas se prestam bem para descrever timbres que ocupam certa faixa intermediária de densidade semântica. Não por acaso, as relações de (i)miscibilidade foram tratadas aqui sempre entre famílias timbrísticas, referidas pelo nome de seu representante mais prototípico: flautas, oboés, violinos, violoncelos, trombones, trompetes etc. Emerge aqui uma interessante correlação entre, de um lado, a (i)miscibilidade timbrística e, de outro lado, seu grau de especificação. Quanto mais inespecíficos forem os timbres, maior propensão à mistura; inversamente, quanto mais específicos, maior propensão à triagem.

Observemos com mais vagar os desdobramentos de tal corolário. Quando lida com a noção de "família" de timbres, a análise aqui desenvolvida se coloca em um patamar de maior especificidade semântica do que aquele envolvido na descrição do perfil temporalaspectual. ${ }^{54}$ Com isso, a sintaxe de triagens e misturas permite refinar a granularidade da análise ao nuançar e subdividir as generalizações de ampla envergadura delineadas naquele primeiro estágio de descrição.

Uma das conclusões intermediárias obtidas pelo trabalho de semiotização do envelope sonoro ${ }^{55}$ é a flagrante heterogeneidade dos termos arregimentados em cada categoria. Unicamente com base na semelhança de seu perfil temporal-aspectual, timbres tidos como díspares eram agrupados sob uma mesma categoria. Tal é o caso, por exemplo, da reunião de congas, cavaquinhos, marimbas, pandeiros, etc. devido a seu aspecto pontual; o mesmo ocorre com o agrupamento de todos os instrumentos de sopro em uma única categoria devido a seu aspecto durativo-cursivo (cf. tabela 3.1, p. 79). Essa sensação de mistura entre timbres díspares decorre precisamente de seu grau mínimo de densidade

\footnotetext{
${ }^{54}$ Cf. Cap. 3.

${ }^{55}$ Cf. Seção 3.6.
} 
figurativa.

No mais amplo platô de generalidade, tudo tende a se equivaler a tudo, criando uma impressão de embaralhamento indiscriminado. Se tendemos a julgar tal mistura como imprópria e inadequada, é porque admitimos, implicitamente, a plausibilidade de níveis ulteriores de especificação semântica. Esse próximo degrau pôde ser adequadamente semiotizado pelas relações de triagens e misturas entre timbres.

Indo para a extremidade oposta, no mais profundo grau de densidade figurativa, o nível de especificação semântica é tal que dificilmente se encontram equivalências entre timbres. O melhor exemplo de tal cenário é a voz humana. Os resultados parciais de nossa investigação sugerem que um tratamento semiótico da voz exige mais densidade figurativa do que aquela trabalhada pela sintaxe de triagens e misturas. Conforme apresentada aqui, as relações de triagem e mistura de timbres tratam "voz humana" como representante de toda uma categoria timbrística ampla, exatamente da mesma maneira como as designações genéricas dos instrumentos ("violão", "violino", "trombone", "saxofone" etc.) recobrem certo espectro de variação interna. Nesse grau de densidade semântica, a voz humana é ainda um magma relativamente homogêneo e, até o momento, nada foi dito ainda sobre os efeitos de sentido gerados pela identificação de vozes específicas, ou seja, aquelas que põem em cena um sujeito único e exclusivo (p. ex.: "Chico Buarque", "Nara Leão", "Ney Matogrosso", "Frank Sinatra" etc.). Se, por um lado, esse nível intermediário de densidade semântica parece suficiente para analisar timbres instrumentais, por outro lado, ele parece ainda insuficiente para compreender timbres vocais naquilo que lhe é mais idiossincrático, a saber, a iconização da fonte sonora. Para tal, será necessário avançar mais um degrau em nossa escala de especificação. É o que faremos a seguir (cf. Cap. 5).

\section{Citações traduzidas no original}

xxxii "C'est parce que j'ai vu, après un travail de cinq ou six ans que la lexicologie ne menait nulle part que les unités /lexèmes/ ou /signes/ ne menaient à aucune analyse, ne permettaient pas la structuration , la compréhension globale des phénomènes - que j'ai compris que c'est "sous" les signes que les choses se passent. Evidemment, une sémiotique, c'est un système de signes, mais à condition de dépasser ces signes et de regarder ce qui se passe sous les signes." (Hénault, 2017, p. 8)

xxxiii “Cependant, l'état discret paraît, dans l'ensemble du corpus, investi d'une importante valeur d'usage : il permet le mélange et le tri, deux opérations qui vont apparaître comme fondamentales dans le traitement de la matière pour fabriquer des objets de valeur."(Bastide, 1987, p. 12)

xxxiv“ (...) un sac de grains peut être considéré comme un objet dans un état discret, et pourtant chaque graine a sa structure, et le sac lui-même peut être structuré : s'il est suffisament secoué, les graines les plus denses seront au fond, les plus légères sur le dessus, formant une structure en couches." (Bastide, 1987, p. 12)

xxxv"Musical elements that are in separate registers are not perceived as being on the same plane of 
tone".(Belkin, 2001)

xxxvi“Consequently, the strings present fewer problems of blend. And, they do not vary in strength from register to register as much as the woodwinds do. This means that balance is more easily calculated." (Kennan, 1983, p. 179)

xxxvii "The group which enjoyed the greatest homogenity of tone-colour, which tired the ear least, and which offered the most perfect blend, namely, the string orchestra, was allowed to speak for itself and to display its own particular tone-colour without constant adulteration." (Carse, 1964 [1925], p. 246)

xxxviii "The low-pitched blends of clarinets and bassoons, or of bassoons, trombones and ophicleide, the high-pitched groups of divided violin parts, and many other effects to be found in Meyerbeer's scores, all appear to stand as patents to many of Wagner's well-known colour-devices ; [...]" (Carse, 1964 [1925] , p. 254)

xxxix "The string parts in the same opera are more complex, less easy to separate into either melodic or accompanying matter, often made up of tiny phases whose function it is to unite in forming a tissue of movement in which every part cannot be, and is no intended to be distinctly heard, a moving texture of sound, the constituents of which act co-operatively rather than individually. Wood-wind and horn parts weave themselves into the fabric without proclaiming their entries, and may be discovered when their presence was unsuspected." (Carse, 1964 [1925], p. 277)

xl "Less excusable were his [Schumann's] frequent failure to secure a satisfactory balance of tone between melodic and harmonic parts, and least of all, his consistent neglect to let the primary colours of the orchestra be heard in their native state, and in clear constrast with the other. The continuously rich tint of his colouring, is due to the employment of strings, wood-wind, and horns in constant combination." (Carse, 1964 [1925], p. 264)

xli "Without entering into technical details, I may explain to my readers that the art of instrumentation (i. e., the distribution of a work amongst the various instruments) consists in understanding how to employ alternatively the individual groups of instruments; how to blend them appropriately; how to economize strong effects - that is to say, the application of timbre (tone-colour) to musical ideas. This knowledge Schumann has not acquired. His orchestra works continuously; all the instruments take part in the exposition and development of his ideas. They are not used in detachments; there is no contrast between them (and contrasting effects are inexaustible in orchestration); most of the time they mingle in a continuous roar, often spoiling the best parts of a work." (Carse, 1964 [1925], p. 306)

xlii "These orchestral tutti marked the beginning of a tendency on the part of many Italian and French opera composers to be content with a noisy bustling type of tutti in which rather thinly represented florid first violin and flute parts struggle against a heavy harmony of the rest of the orchestra. Even if a piccolo part sometimes rescued the melodic part from being completely swamped by a torrent of harmonic padding, it cannot be said that the type of tutti, so frequently encountered in the operatic ouvertures of such as Boieldieu, Rossini, Herold and Auber, degenerating as they often did into a more or less exhilarating noise, is anything like so well-balanced as that of Weber." (Carse, 1964 [1925],p. 239) xliii "Composers writing at the very end of that century have often run the risk of tiring the ear by too frequent changes of tone-colour, or in other words, by too-closely packed variety. That there is a risk can be proved by carrying the process to extremes. If one could produce sixty different varieties of tone-colour in succession during the course of a minute, and could then continue to provide them in infinite variety for a quarter of an hour, the hear would not be conscious of having heard any of them; they would simply merge into one continuous roll of sound, and one of the most deadly monotony. Therefore, by providing the utmost variety of tone-colour at too short intervals, the ear, having no time to dwell on any of them, refuses to recognize any variety at all." (Carse, 1964 [1925], p. 332-333) 
xliv "No further variety could be extracted even from this huge orchestra as long as the same course of development was pursued. No fresh colours could be created by a mere increase in tone-volume; Strauss had got so much colour on his orchestral palette that continued mixing of them produced no novel tints." (Carse, 1964 [1925], p. 321)

xlv "[...] but, if the lessons of Teutonic orchestration in the early years of this century have been properly learned, they will surely prove to have shown that orchestration has nothing more to gain from a mere increase in volume of sound; that variety of colour, of treatment and texture, have more to offer; that the ear will find continued stress and complexity of construction in the long run as monotonous as continued dullness, and that periods of restfullness alone can serve to give contiguous periods of excitement and energy their due effect." (Carse, 1964 [1925],p. 322)

xlvi "By adding more to the number of instruments already represented, and by adding still more representatives of the same type, but of either higher or lower pitch, the volume of available sound was increased, but without corresponding gain of variety of effect. Time will probably show that the culmination of the growth of the orchestra, that is, merely as regards its bulk or numbers, was reached by about the beginning of the present century, and that orchestration at that time did not owe its further advancement to any increased volume of sound, but rather to increased variety of treatment of the instruments, or the groups of instruments, which were already long and firmly established members of the combination." (Carse, 1964 [1925], p. 314)

xlvii "La musique de Giacinto Scelsi, par exemple, est une musique d'indistinction. Elle-même n'est pas purement indistincte, mais elle procède par indistinction et ce à au moins deux niveaux. [...] Les œuvres de Scelsi sont avant tout des masses, des fluides en fusion où s'amalgament de manière fantastique les sonorités des instruments et où le phénomène acoustique prime sur une organisation note à note. [...] La musique de Scelsi préfigure la possibilité d'un usage unique du drone comme paradigme musical. [...] Chez Scelsi, comme dans les drones, la musique se conçoit bien plus comme une matière fluide, une énergie, que comme la manifestation d'un discours se développant dans le temps." (Bonnet, 2012 ,p. 200) xlviii "[...] : la musique des siècles passés déployait toutes ses forces dans le savant tissu poliphonique ; chaque instrument, chaque musicien était une partie anonyme du tout. Chaque instrument devait dessiner sa ligne aussi clairement que possible et mêler en même temps à la sonorité d'ensemble sa teinte particulière. Or vers 1600, de nouvelles forces entrèrent en jeu. [...] Même la musique purement instrumentale fut entraînée par cette vague et le soliste sortit de l'anonymat qui était celui du musicien d'ensemble." (Harnoncourt, 1982, p. 146-147)

xlix "Le basson n'a pas de voix propre, et suit simplement les violoncelles et les contrebasses ; [...]. Il arrive toutefois que Telemann requière un quatuor complet de vents : trois hautbois et basson. [...] Cette possibilité conduit à un mode d'écriture particulier : le dialogue ne se déroule désormais plus uniquement au sein de sonorités homogènes par l'alternance de motifs et de figures, mais entre des groupes sonores fondamentalement différents." (Harnoncourt, 1982, p. 224)

1"The wood-wind group, less cohesive but very distinctive, was likewise allowed to have its say as an independent group, in spite of a tendency to rather frequently amalgamate with the tone of horns. The brass, now enjoying the great benefit of at least three completely chromatic members, namely, the trombones, had become harmonically more or less self-contained, and could be trusted to speak alone without the co-operation of unrelated types of instruments." (Carse, 1964 [1925] ,p. 246)

li "L'orchestre de la première moitié du XVIIIe siècle était un « instrument » très finement ajusté dans ses timbres et la fusion de ses couleurs. [...] . Il est évident que, pour une telle instrumentation, la façon particulière dont la sonorité des instruments se fond entre eux est d'une grande importance. Ainsi, par exemple, la sonorité mêlée du hautbois et du violon est véritablement l'épine dorsale de la sonorité 
de l'orchestre baroque. Cette écriture colla parte est assouplie par des soli instrumentaux concertants, dans lequels les divers groupes instrumentaux (trompettes, flûtes, hautbois, cordes) resortent seuls de la sonorité fondue des blocs en tutti [...]." (Harnoncourt, 1982 ,p. 151)

lii "Le bassoon baroque fait vraiment sonner le bois, presque comme un instrument à cordes, [...]. Il est conçu de façon à se fondre de manière idéale avec le violoncelle et le clavecin dans la basse continue, mais en même temps à donner à la basse un tracé et un contour clairs." (Harnoncourt, 1982 ,p. 156)

liii "Pour faire ressortir cependant et renforcer la ligne de basse de manière correspondante, la gambe, le violoncelle ou la contrebasse, parfois même le basson, jouent le plus souvent la voix la plus grave avec le clavecin."(Harnoncourt, 1982 , p. 158)

liv "The latter [ trombone trio] were treated almost entirely as harmonists, except occasionally when suitable matter in the bass part offered opportunity for some thematic interest. More novel was the use of trombones for very soft harmony, such as occurs in some of Schubert's later symphonies, and in Weber's operas. The use of trombones at selected moments simply in order to give more volume to particular chords, or to build up and emphasize a climax, shows some advance on the older style which kept these instruments playing more continuously in the movements in which they took part. [...]; thus the effect of unmixed brass-tone was one which was largely denied to early nineteenth century composers." (Carse, 1964 [1925] , p.229-230)

lv "Apart from the imitative phases which occur in the course of ordinary four-part polyphony for string instruments, the viola as a group, and without reinforcement, were as yet hardly recognised as melodists, nor is there reason to suppose that the peculiarly attractive and individual timbre of viola-tone was really appreciated at this period, in spite of Gluck's suggestive lead, and of Weber's readiness to exploit the dramatic possibilities of this neglected instrument. Both Berlioz and Wagner have testified to the inferior skill and status of orchestral viola players even at a later date, and it is not difficult to see how the prevailing conditions are reflected in the viola parts written early in the century"(Carse, 1964 [1925], p. 226-227)

lvi "The wood-wind as a body take a very generous share of the musical matter, doubling one another each in its respective register, or, rather less frequently, acting as an independent group, but rarely as unencumbered soloists." (Carse, 1964 [1925],p. 295-296)

lvii "The horns act as a binding material, and are almost continuously employed as such, providing a somewhat monotonous cohesion by means of parts which are not exactly melodic, yet are more than mere harmonic padding." (Carse, 1964 [1925], p. 296)

lviii "Very sharp contrasts are, on the whole, avoided by smoothing down the colour-outlines by a process of overlapping the tone-colours, a characteristic of Elgar's which grew as the development of his orchestral style procceeded." (Carse, 1964 [1925],p. 326)

lix"Elgar's individuality in his orchestration lies in his highly developed faculty for blending tone-colours; the primary colours of the orchestra are rarely employed in an unmixed state [...] The parts are distributed in a manner which provides plenty of colour-contrasts, but these merge one into the other without exposing clearly defined boundaries." (Carse, 1964 [1925],p. 327)

lx"While Tschaikovsky aimed at very clear definition of each part by concentrating instruments of allied tone-colour on any one part, Elgar selects from various types of tone-colour and secures equal richness and sonority, yet less clearly defined part-outlines."(Carse, 1964 [1925] ,p. 327)

lxi "His appealing string melodies are accompanied by full-bodied blends of wind-tone, his wind melodies by quiet unobtrusive string tone. Horns are used to give richness and body to the wind harmonies, or to blend in smooth-toned co-operation with the bassoons."(Carse, 1964 [1925], p. 236)

lxii "La douceur de sa sonorité permet de préserver les nombreuses peintures sonores très subtiles que 
réalisent les instruments à cordes - ce qui n'est pas le cas avec l'attaque incisive du clavecin.(Harnoncourt, 1982 , p. 195)

lxiii "As a solo instrument the clarinet began to assert itself only very gradually in spite of Mozart's example, and not till early the end of the first quarter of the [nineteenth] century did it stand on an equality with the other wood-wind instruments in this particular capacity. The readiness with which clarinet-tone blends with the tone of bassoons, horns, and with string-tone, had an even more far-reaching influence on orchestration as a whole than the gain of a new solo voice. The smooth-toned combinations of clarinets and bassoons, or clarinets, bassoons and horns, began to replace the wood-wind combinations in which the more incisive-toned oboe had previously always had a place when, early in the nineteenth century, the new-comers had at last secured an assured place in all orchestras. A distinct preference for the warmer and round-toned blends, in which clarinet-tone largely replaced the hitherto predominant oboe-tone, is a feature of orchestration which became very marked during the maturity of Beethoven, Weber and Schubert, and marks the end of the long reign of the oboe as chief and leader of the wood-wind group. Other blends which excluded oboes, and became more common during the same period, were horns and bassoons, and flutes and clarinets." (Carse, 1964 [1925], p. 228-229)

lxiv "In general, an unevenness results from the association, in a chord, of a weak with a strong register of the same instrument (Fig. 154a). Likewise, combining tones of the weak register of one instrument with tones of the strong register of another instrument will probably result in poor balance (Fig. 154b). It cannot be too strongly emphasized that examples of chords for instrumental combinations have validity only for the pitch at which they are given. If a chord is transposed, the relationship of registers changes. In Fig. 154(c), flute and oboe will be found to be nicely balanced, while in (d) the flute has a distinct advantage over the oboe". (Piston, 1955, p. 446)

lxv "The grouping of his tone-colours is well-concentrated, excellently clear, yet obvious in design. His readiness to exploit all new devices is patent in all his scores, and it is more in the different texture of his musical matter, than in intention, that his orchestral effects differ from those of Wagner. Strings, wood-wind, and brass are given clearly differentiated functions. Groups are harmonically satisfying and well blended, and the free use and power of the brass-unison against string figuration is thoroughly appreciated." (Carse, 1964 [1925],p. 282)

lxvi "La poésie « doit tendre de plus en plus à exercer son pouvoir inégalabe, unique, qui est de faire apparaître l'unicité concrète des deux termes mis en rapport et de communiquer à chacun d'eux, quel qu'il soit, une vigueur qui lui manquait tant qu'il était pris isolément.»”. (Zilberberg, 2011a,p. 22)

lxvii "Both Bellini and Donizetti were ready to seize on the melodic and harmonic advantages of the valve horns and trumpets, and made good use of the wind-band unmixed with string tone. Both avoided the inevitable monotony of too constantly combining strings, wood-wind, and horns, and fully understood the value of allowing the primary tone-colours of the orchestra to be heard separately as foils one to the other." (Carse, 1964 [1925], p. 251)

lxviii “[...], Rossini's contributions to the growth of orchestration were all to the good. He took the lead in keeping the pure and elementary colours of the orchestra clearly differentiated, and to some extent counteracted a tendency towards monotony which was caused by too constantly employing various types of tone-colour in neutral-tinted and non-characteristic combinations. Rossinis solo parts stand out in strong relief against the harmonic backgrounds of his accompaniments. The clear utterance of melodic wind-parts is not blurred by sustained harmonic padding on voices of too closely related tone-colour; contrapuntal decoration interferes with the functions of neither melodic nor accompanying parts, and neither lose their individuality as the result of over-blending or intermixing the colours." (Carse, 1964 [1925], p. 240) 
lxix"As a general principle, timbres which blend well in chords present little or no contrast when heard in succession; timbres which do not blend in chords make for stronger contrasts." (Belkin, 2001, cf.: https://alanbelkinmusic.com/site/en/index.php/orchestration-notions-1/)

lxx“La disposition séparée du concertino (le groupe soliste d'un concert) et de l'orchestre était en usage partout, afin de rendre clair le dialogue ou tel effet d'écho. Il se pose à ce propos un problème particulier dans le cas de concertos pour plusieurs clavecins ou pianos. Ceux-ci sont aujourd'hui disposés le plus souvent de telle manière que le dialogue entre les instruments voulu par le compositeur passe inaperçu, parce que'ils sont placés le plus près possible l'un de l'autre. On obtient ainsi plutôt la sonorité d'un clavecin ou piano unique, renforcé, et non celle de plusieurs instruments qui parlent entre eux. Pour créer les conditions idéales, il faudrait essayer de disposer les instruments aussi loin que possible l'un de l'autre, afin d'aboutir à un résultat optimum dans la séparation du son, sans mettre en péril pour autant l'indispensable jeu d'ensemble." (Harnoncourt, 1982 ,p. 117)

lxxi " Orchestration by early nineteenth century composers shows thorough appreciation of the value of clearness in dealing with the colours of the orchestra. The tone of each instrument is allowed to be heard in its native state as well as with the admixture of alien tone-colour; solo parts are judiciously accompanied by others whose tone-colour does not detract from or smother the individuality of the solo instrument, and the various groups consisting of instruments of related tone-colour are freely contrasted, as well as combined, one with the other. Monochromatic or neutral-tinted orchestration, the result of too constantly combining strings, wood-wind and horns, was a later growth for which certain German composers were largely responsible.(Carse, 1964 [1925],p. 230)"

lxxii "Again, Berlioz had no illusions as to the power of the wood-wind against sonorous, full matter on the strings. If necessary he concentrated the full wood-wind section in octaves on one part, so that independent or essencial matter should stand out clearly, and cut its way through the thick wall of string tone." (Carse, 1964 [1925],p. 260)

lxxiii "The segregation of the function of each instrument or group of instruments at any particular moment, the clear distinction between the tone-colour, the spacing of change of colour, the knack of using very few notes effectively, and of avoiding combinations in which one tone-colour cancels the individuality of another; all these give variety, clearness, and balance to the work of Saint-Saëns, and place his work at the extreme opposite to that of Brahms and many of his German contemporaries." (Carse, 1964 [1925] ,p. 300)

lxxiv“Dès le début du XVIe siècle la gambe fut construire en choeurs, c'est-à-dire qu'on fabriqua des instruments de taille différente pour le soprano, l'alto, le ténor et la basse. Avec de telles formations on jouait esentiellement des oeuvres vocales, que l'on adaptait aux instruments au moyen d'une ornamentation appropriée. [...] A cette époque le violon ne comptait pas encore au nombre des instruments respectables, et servait en premier lieu à la musique de danse improvisée." (Harnoncourt, 1982 ,p. 141)

lxxv "Dans l'ensemble, on observe un appauvrissement de la palette sonore, puisque dans l'orchestre moderne tous les instruments tendent vers une sonorité ronde, pauvre en harmoniques aigus, alors que dans l'orchestre baroque la différenciation des groupes instrumentaux était plus marquée et donc plus riche."(Harnoncourt, 1982, p. 140)

lxxvi "A very important feature in the growth of orchestration of this period was due to the increased use of the violoncello as an independent voice. From being at first only a bass instrument, the violoncello had become an occasional tenor instrument towards the close of the eighteenth century, and now early in the orchestra as a full-blown melodist which, in addition to its former functions, was ready and able to take over the responsibility of presenting entirely melodic matter, either with or without the aid of other instruments." (Carse, 1964 [1925], p. 225-226) 
lxxvii "Ces instruments [hautbois d'amour; hautbois da caccia], en raison de leurs timbres particuliers, étaient avant tout employés pour les soli, mais doublaient également parfois les voix intermédiaires de l'orchestre à cordes. La flûte traversière est un instrument soliste typique, et il n'est que très peu d'oeuvres d'orchestre de l'époque baroque où elle soit employée exclusivement comme instrument de tutti." (Harnoncourt, 1982 , p. 156)

lxxviii "Les instruments à vent de l'époque baroque étaient construits de sorte qu'ils avaient d'une part une sonorité aisément reconnaissable en solo et que d'autre part ils pouvaient facilement s'unir [mistura; fusão] à d'autres instruments de la même tessiture en un mélange sonore nouveau. L'exemple le plus caractéristique en est le hautbois. (L'alliance du hautbois et du violon constitue en effet l'essence sonore de l'orchestre baroque.)" (Harnoncourt, 1982, p. 155)

lxxix "Meyerbeer, in particular, showed no hesitation in displaying unmixed brass-tone of a hitherto unknown richness which was due simply to the free choice of notes at his disposal in the upper brass parts." (Carse, 1964 [1925])

lxxx"The three main instrumental groups of the orchestra were to Glinka so many distinct and selfcontained bodies whose functions should be clearly separated, and whose colours should be used in sharp contrast with one another, rather than as three parts of a whole whose individual characteristics should be modified and toned down as far as possible by means of combination, by intermixing and blending of tone-colours." (Carse, 1964 [1925], p. 249)

lxxxi "A central goal of phonology is to characterize the possible words of individual languages. In any language, the lexicon contains only a fraction of the phonologically possible wordforms. All other forms that are possible (but have no meaning) are pseudowords." (Needle, 2017, p. 3)

lxxxii “La figure est en effet descriptible comme une des modalités possibles de la gestion des écarts, l'écart n'étant rien d'autre qu'une atteinte aux règles de combinaison prévues par la grille (la coexistence de la fourrure et du bec chez l'ornithorynque constitue une de ces atteintes, au même titre que l'énoncé « le pneu X boit l'obstacle », où l'on constate l'apparition d'un substantif ne comportant pas le sème " liquidité » derrière un verbe dégageant le classème " liquidité »). Nous donnos à cette atteinte le nom d'allotopie, [...]... (Groupe $\mu, 2015$,p. 464) 


\section{Capítulo 5}

\section{TIMBRE E BREAGEM: OPERAÇÕES ENUNCIATIVAS}




\section{Capítulo 5}

\section{Timbre e breagem: operações enunciativas}

\subsection{Timbre e enunciação}

Falar em timbre é falar inevitavelmente em "impressão digital sonora". Embora seja a concepção mais corriqueira, ela tem sido relegada a segundo plano até aqui pela presente investigação. Isso acontece porque esse efeito de fisionomia individual exige um máximo grau de densidade figurativa do timbre ${ }^{1}$. Deixada na penumbra pelas análises de perfil temporal-aspectual ${ }^{2}$ e de (in)compatibilidade intertimbrística ${ }^{3}$, ela passa agora a assumir papel central.

Foi a reflexão sobre os sentidos da voz que levou pesquisadores a detectar a função do timbre de ancoragem à pessoa. Essa remissão é sempre referida algo obliquamente por expressões que variam entre "metonímia do sujeito", "extensão corporal do intérprete", "efeito de presença", "ilusão enunciativa" entre outras. ${ }^{4}$ A se basear pelo entendimento corrente nos estudos semióticos, tudo se passa como se o timbre estabelecesse uma ponte direta com o sujeito. Nesse ponto, ele poderia ser comparado aos pronomes dêiticos das línguas naturais ("eu", "tu" etc.). Pode-se, porém, questionar se essa aproximação é de fato legítima e em que medida ela se justifica.

Para responder essa pergunta com conhecimento de causa, é preciso recuperar o conceito de enunciação. Marca distintiva de uma abordagem semiótica de filiação linguística, esse instrumento analítico coloca-a em vantagem frente a outros programas de investigação concorrentes, tais como a musicologia, a organologia, a semiótica peirceana,

\footnotetext{
${ }^{1}$ Cf. Cap. 2, p. 67.

${ }^{2}$ Cf. Cap. 3.

${ }^{3}$ Cf. Cap. 4.

${ }^{4}$ Cf. Cap 2, p. 23 ss.
} 
a fonoestilística entre outros. Por esse ângulo, o timbre pode então ser entendido como marca do sujeito da enunciação no enunciado. O exame do timbre em seu comportamento enunciativo propriamente dito permite descrever, com maior precisão analítica, um fenômeno de sentido caracterizado até então em termos inexatos.

\subsection{A enunciação e suas marcas}

\subsubsection{Definições canônicas}

No grande arco histórico da linguística a partir de Saussure, coube a Émile Benveniste (2006 [1974]) o estudo pioneiro da inserção do sujeito na linguagem por meio da enunciação. Até então, as ciências da linguagem limitavam seu escopo de descrição tanto quanto possível à estrutura interna do enunciado. Aspectos relacionados às condições de produção, ao uso e à assunção da língua pelo sujeito eram, salvo notórias exceções, tratadas como variantes contingenciais não-pertinentes ao objeto de análise.

Quando traz à luz suas reflexões sobre o aparelho formal da enunciação e a subjetividade na linguagem, Benveniste (2006 [1974]) descortina todo um vasto campo de estudos a ser desbravado pela linguística. A língua não pode mais ser vista apenas como um repositório estático de formas fonológicas e morfossintáticas; sua colocação em uso pelo sujeito deve agora ser igualmente contemplada. Consagrando tal gesto de apropriação, assim declara esse autor: "A enunciação é este colocar em funcionamento a língua por um ato individual de utilização" (Benveniste, 2006 [1974], p. 82). A enunciação marca um ponto de virada da língua para o discurso e exige o engajamento do sujeito em seu "ato individual". Essa passagem à colocação da língua em uso não se dá de forma acidental; ao contrário, ela está submetida a certas coerções reguladoras.

A apropriação da linguagem pelo sujeito é norteada por certos modos de uso, reconhecíveis em vestígios concretos: "A relação do locutor com a língua determina os caracteres linguísticos da enunciação.” (2006 [1974],p. 82). Instância de mediação entre sujeito e língua, esses "caracteres linguísticos" são sistematizados por Benveniste (2006 [1974]) no aparelho formal da enunciação, indiscutivelmente estabelecido hoje nos estudos discursivos. Assim procedendo, o autor demonstra que tal apropriação nada tem de contingente, ao contrário do que o qualificativo "individual" pode dar a entender. Ainda que com outras palavras, o autor volta a pontuar o papel desempenhado por esses elementos:

A presença do locutor em sua enunciação faz com que cada instância de discurso constitua um centro de referência interno. Esta situação vai se manifestar por um jogo de formas 
específicas cuja função é de colocar o locutor em relação constante e necessária com sua enunciação. (Benveniste, 2006 [1974], p. 84, grifos nossos)

Cumpre ressaltar a inescapabilidade desse "jogo de formas", que controlam a relação do locutor com a enunciação. Não é possível se apropriar da língua por meio da enunciação sem nela deixar suas marcas. A instauração do sujeito como centro de referência implica inevitavelmente a inscrição de vestígios rastreáveis no enunciado produzido. A organização dessas marcas constituem o que Benveniste (2006 [1974]) trata como uma "gramática do discurso", em contraposição à "gramática da língua". A esse respeito, o autor chama a atenção para uma distinção universal na categoria de pessoa, a partir da qual ele desdobrará toda sua reflexão sobre o sistema enunciativo:

Com efeito, a língua fornece ao falante a estrutura formal de base, que permite o exercício da fala. Ela fornece o instrumento linguístico que assegura o duplo funcionamento subjetivo e referencial do discurso: é a distinção indispensável, sempre presente em não importa qual língua, em não importa qual sociedade ou época, entre o eu e o não-eu, operada por indices especiais que são constantes na língua e que só servem a este uso, as formas chamadas em gramática de pronomes, que realizam uma dupla oposição, a oposição do 'eu' ao 'tu' e a oposição do sistema 'eu/tu' a 'ele'. (Benveniste, 2006 [1974] ,p. 101, grifos nossos)

Grande parte da arquitetura linguística da enunciação está apoiada sobre essa distinção entre "pessoa vs. não-pessoa". Ao primeiro eixo, pertence tudo o que é da ordem da enunciação propriamente dita, posteriormente alcunhado "enunciativo"; ao segundo, pertence o que é da ordem do enunciado, referido como "enuncivo". As duas oposições apontadas por Benveniste (2006 [1974]) foram incorporadas ao repertório conceitual da semiótica greimasiana e, com os shifters (embreantes) propostos por Jakobson (1963), resultaram nas operações enunciativas de debreagem e a embreagem (Bertrand, 2003,p. 89-90). Embora já amplamente estabelecidas na literatura semiótica (cf. Fiorin, 1999), convém recapitular sucintamente tais operações para dar assistência ao leitor menos familiarizado com tal quadro teórico. ${ }^{5}$

A debreagem enunciativa de pessoa diz respeito à projeção no enunciado dos actantes da enunciação (eu/tu), reconstituíveis pelo emprego de formas verbais e pronominais de primeira e de segunda pessoa (Fiorin, 1999, p. 43, 61). Um exemplo trivial é o enunciado "Eu sei que vou te amar". Nele, os pronomes "eu" e "te" e a flexão verbal de

\footnotetext{
${ }^{5}$ Sem ignorar o papel desempenhado pelas categorias de tempo e espaço, a exposição a seguir se concentra na categoria de pessoa por motivos de clareza e concisão.
} 
primeira pessoa em "sei" e "vou" desencadeiam uma debreagem enunciativa de pessoa, pois ancoram o enunciado à instância da enunciação.

Por sua vez, a debreagem enunciva de pessoa trata da instalação dos actantes do enunciado (Fiorin, 1999 , p. 44). Esses são, tradicionalmente, identificáveis pelo uso de expressões nominais, bem como de formas verbais e pronominais de terceira pessoa. Um enunciado como "Carcará lá no sertão é um bicho que voa que nem avião" ilustra bem a debreagem enunciva de pessoa, desencadeada pelas expressões nominais "carcará", "um bicho" e "avião", bem como pelas flexões verbais de terceira pessoa em "é" e "voa".

Por fim, fala-se de embreagem quando há a suspensão dessas oposições. Em outras palavras, formas do sistema enunciativo são empregadas em lugar de formas do sistema enuncivo - e vice-versa. Para ilustrar a embreagem de pessoa, Greimas \& Courtés (2012 [1979] , p. 160) retomam uma fala do general De Gaulle quando se refere a si próprio usando uma forma de terceira pessoa: "O general de Gaulle pensa que ...". Nesse caso, a embreagem decorre de "um efeito de identificação entre o sujeito do enunciado e o sujeito da enunciação", para retomar ainda as palavras dos próprios autores (2012 [1979], p. 160). Na mesma direção, Fiorin (1999, p. 85) dá como exemplo o enunciado "O Papa leva no fundo do coração o desejo e a esperança de que a Nação brasileira trilhe sempre a senda da valorização da dignidade do homem", proferido pelo próprio Papa. Observa-se, mais uma vez, o emprego de uma expressão nominal em lugar de um pronome de primeira pessoa.

Apresentados os fundamentos das operações enunciativas em sua definição mais canônica, cumpre pontuar algumas ressalvas. Usualmente, a inscrição do sujeito se encontra em marcas concretas do enunciado, das quais o sistema pronominal é o exemplo mais proeminente - porém não o único. Conforme foi apropriada e difundida, a noção de aparelho formal da enunciação acabou passando por certas simplificações reducionistas que requerem certa atitude de cautela:

Mas a abordagem de Benveniste implicava, em seus próprios princípios teóricos, que se ultrapasse o estágio das 'marcas formais da enunciação' e se considere o discurso como um indice global de subjetividade. Essas considerações são importantes, na medida em que a atualização das marcas formais da enunciação representa, de fato, a caricatura do que se retém da teoria da enunciação. Acontece aqui o que aconteceu com outros sistemas de pensamento (e, em primeiro lugar, com a linguística de Saussure): a redução de uma teoria a dados formais, diretamente 'utilizáveis' por procedimentos heurísticos ou pedagógicos. Restringir a teoria da enunciação de Benveniste apenas à análise de índices ad hoc da língua traz de fato o risco de ocultar as perspectivas abertas pelo que constitui, antes de tudo, uma teoria global da linguagem. 
(Dessons, 1993, p. 44, grifos no original, tradução nossa lxxxiii)

Em terreno semiótico, semelhante ressalva já foi pontuada em Fontanille \& Zilberberg (2001) ao alertar para o risco de uma interpretação excessivamente restrita e instrumentalizada do pensamento de Benveniste (2006 [1974]).

A apropriação é, de acordo com Benveniste, o ato 'que introduz aquele que fala em sua fala', mas tal definição, situada no contexto do aparelho formal da enunciação, foi geralmente interpretada de maneira restritiva, ou seja, apenas em termos dêiticos e modais. Na verdade, o sujeito do discurso se apropria mais amplamente da língua, [...] (Fontanille \& Zilberberg, 2001,p. 199)

Aos linguistas não passou despercebido esse desvio de percurso na recepção e na propagação das ideias de Benveniste sobre a apropriação da língua pelo sujeito. Nesse trajeto, pronomes e desinências verbais acabaram se impondo como as marcas linguísticas mais evidentes. Elas não podem, porém, ser consideradas como as únicas. Além delas, existem outras marcas indiciais desse gesto de apropriação da língua pelo sujeito. Para poder vislumbrá-las, é preciso contudo lançar o olhar um pouco mais adiante.

\subsubsection{Enunciação e breagem sensível}

O desenvolvimento das reflexões sobre a enunciação, suas marcas e suas operações privilegiaram a linguagem verbal, cujo aparato enunciativo foi formalizado com riqueza de detalhes. Comparativamente, uma semelhante descrição para as linguagens não-verbais se revela bem menos sistematizada, embora prevista em princípio. No atual estágio de avanço da área, nenhuma dúvida resta sobre a pertinência das operações enunciativas às mais diversas línguas naturais e também às mais diversas linguagens de manifestação:

Os mecanismos de debreagem e de embreagem não pertencem a esta ou àquela língua, a esta ou àquela linguagem (a verbal, por exemplo), mas à linguagem pura e simplesmente. Da mesma forma, todas as línguas e todas as linguagens possuem as categorias de pessoa, espaço e tempo, que, no entanto, podem expressar-se de maneira diferente de uma língua para outra, de uma linguagem para outra. (Fiorin, 1999, p. 52)

A declaração encarna plenamente os princípios epistemológicos da semiótica e, no entanto, suas decorrências práticas ainda permanecem subexploradas. Não basta apenas reafirmar a transversalidade dos mecanismos geradores de sentido. É preciso também 
descrever as astúcias enunciativas nessas outras linguagens de manifestação com o mesmo nível de detalhamento atingido pelos trabalhos com as línguas naturais.

Ainda a esse respeito, uma segunda ressalva deve ser colocada. Mesmo no domínio do verbal, a modalidade escrita da língua parece ter sido privilegiada em detrimento da modalidade oral, ao menos a se pautar pelos exemplos apresentados pela literatura corrente (Fiorin, 1999; Greimas \& Courtés, 2012 [1979]; Bertrand, 2003). Quando se trata de examinar as operações enunciativas, as análises parecem abstrair a antecedência da oralidade à escrita, tão cara ao pensamento de Saussure (1991 [1916], p. 34-35) que preside a semiótica discursiva. Tal déficit se assoma ao levarmos em consideração as especificidades que distinguem essas duas modalidades de língua. Essa via não desbravada se encontra, aliás, já esboçada no pensamento do próprio Benveniste (2006 [1974]):

Muitos outros desdobramentos deveriam ser estudados no contexto da enunciação. [...] Seria preciso também distinguir a enunciação falada da enunciação escrita. Esta se situa em dois planos: o que escreve se enuncia ao escrever e, no interior de sua escrita, ele faz os indivíduos se enunciarem. (Benveniste, 2006 [1974] ,p. 90)

Logo após pontuar a necessidade de distinção entre fala e escrita, a argumentação passa, logo em seguida, a se ocupar das características da assim chamada enunciação escrita, deixando para trás a assim chamada enunciação falada. O que afirma Benveniste a respeito da escrita poderia bem ser replicado à enunciação de textos orais. Parafraseandolhe os termos, seria possível dizer então que "o que fala se enuncia ao falar". Mais do que mero jogo de palavras, essa possibilidade de desdobramento mostra que a incorporação da voz e do timbre na enunciação de textos orais não somente é plausível, mas também imperiosa, contanto que se deseje considerar suas singularidades. Cumpre frisar que, ao falar em textos orais, deve-se considerar toda a diversidade de formas de oralidade, desde a conversação coloquial até a prosódia melodizante da palavra cantada, passando por todo o espectro intermediário de falas ritualizadas, tais como a prece, o bordão de torcida esportiva, o pregão, a fala ritmada (joint speech) etc.

Cada qual a seu modo, ambas as citações antecipam tal possibilidade de examinar as marcas da enunciação inscritas na oralidade, considerando aqui o timbre como uma delas. ${ }^{6}$ Essa perspectiva pode ser retomada e ganha relevo com as novas propostas sobre a noção de "debreagem sensível" nas mais diversas linguagens estéticas (cf. EstayStange, 2011, 2014b; Estay-Stange \& Bertrand, 2014a). Segundo esses estudos, uma debreagem sensível é desencadeada por vestígios corporais deixados pelo enunciador no

\footnotetext{
${ }^{6}$ Os trabalhos de fonoestilística constituem uma profícua frente de trabalho nessa direção. A esse respeito, cf. Léon (1993).
} 
enunciado, como é o caso da voz na música e do traço nas artes visuais. Na qualidade de prolongamento corporal e gestual, esse vestígio permite reconstruir a presença do sujeito, sempre logicamente pressuposta ao enunciado.

Assim como a debreagem cognitiva, a debreagem sensível que resulta da emissão da voz ou da produção do traço plástico supõe a projeção de um 'não-eu, não-aqui, nãoagora'. Pois tanto a voz como o traço plástico implicam um desdobramento do sujeito, um destacamento de si mesmo: aquele que fala escuta sua própria voz e aquele que pinta observa seu próprio traçado ou seu próprio toque. (EstayStange, 2011 , p. 20, tradução nossa ${ }^{\text {lxxxiv }}$ )

O já bem estabelecido conceito de marcas da enunciação ganha aqui contornos mais amplos, de modo a integrar também dados da ordem do sensível. Além de reverberar a concepção de voz como metonímia corporal (Tatit, 1997; Parret, 1988, 2002, 2010)7 tal conceito de prolongamento do sujeito permite operacionalizar o comportamento enunciativo do timbre. Assim como as formas dêiticas de primeira pessoa projetam o sujeito no enunciado - rememorando a máxima de Benveniste (2005 [1966]): "É eu quem diz $e u^{\prime \prime}$ ) - o timbre cumpre função equivalente na margem sensível do exercício da enunciação.

Assim sendo, haveria também, paralelamente ao sistema enunciativo verbal, algo como uma "dêixis sensível" em funcionamento e desencadeada pelo timbre. Em respeito à coerência teórica do conjunto, tal operação demanda alargar o escopo de abrangência do conceito de enunciação. ${ }^{8}$ Ao discutir as condições dessa expansão, Estay-Stange (2014b) respalda-se em Merleau-Ponty (1999) para delinear uma enunciação corporal depreensível a partir das "operações perceptivas subjacentes ao gesto dêitico" (2014b, p. 4). Sob essa perspectiva, a instauração do centro de referência interno no qual se instala o "ponto-zero" do eu-aqui-agora da enunciação é vista como uma tomada de posição inerentemente somática e perceptiva. Isso cria condições favoráveis para entender o timbre como marca da enunciação no enunciado, na mesma direção do que Estay-Stange (2014b) tem proposto como debreagem sensível.

\subsubsection{Timbre como desencadeador de breagem sensível}

Essa pertinência enunciativa do timbre já tinha sido vislumbrada em Carmo Jr. (2007, p. 175) quando se refere ao timbre como marcador da categoria de pessoa na

\footnotetext{
${ }^{7}$ Cf. Cap. 1, p. 15.

${ }^{8}$ Faça-se constar que, até o presente momento, tais reconfigurações conceituais não são unânimes na área, a exemplo do que mostra o debate entre Fiorin (2017b) e Mancini (2019a) sobre a conciliação das concepções de enunciação na semiótica dita padrão e no ponto de vista tensivo.
} 
enunciação musical ${ }^{9}$ e também em Dietrich (2008) e em Tatit (1986) na análise da distribuição de timbres para simular diálogos internos na canção. ${ }^{10}$ É contudo em Tatit (2016) que se encontram as evidências mais poderosas a favor do timbre como desencadeador de debreagem sensível. Esse trabalho destaca as idiossincrasias que tornam a linguagem da canção inelutavelmente comprometida com a criação de ilusão enunciativa, esta entendida como a construção do efeito de sentido de alguém que se dirige a outrem em um aqui-agora (Greimas \& Courtés, 2012 [1979], p. 161). Dentre os argumentos apresentados, vale a pena destacar a seguinte passagem colocando em relevo esse papel da voz e do timbre:

As marcas enunciativas contidas nas letras (aquelas que fazem alusão ao 'eu-aqui-agora'), incrementadas pelas unidades entoativas e pela própria linha vocal, indice de um corpo sensivel, estão sempre apontando para o dono da voz e revelando de certo modo o seu comprometimento com tudo que diz. (Tatit, 2016 , p. 133, grifos nossos ${ }^{11}$ )

Paralelamente às marcas enunciativas contidas na letra da canção, também a voz cumpre seu papel de remissão à instância da enunciação. Dessa forma, o efeito enunciativo dos marcadores verbais é corroborado pelo timbre vocal na qualidade de "índice sensível". Assim sendo, é duplo o engate do enunciado cancional com seu sujeito, a um só tempo de natureza verbal e não-verbal.

Na sequência, Tatit (2016,p. 134-139) avalia como o retorno à figura do "eu" operado pela voz funda a credibilidade da linguagem da canção e veio a catalisar o processo de emergência dos "compositores-intérpretes" ao longo da década de 1960 no Brasil. Esse emblemático momento da história da canção popular brasileira é ilustrado por canções como "A Banda", interpretada pelo próprio Chico Buarque, e "Disparada", interpretada pelo próprio Geraldo Vandré e posteriormente por Jair Rodrigues. Daí em diante, compositores passaram a ganhar cada vez mais espaço na interpretação de suas próprias criações. O autor menciona ainda que, até então, era comum que os ouvintes se referissem às canções identificando-as ao intérprete. Comentando a força pregnante daquilo que chama de "efeito bumerangue da voz", Tatit (2016, p. 136) aponta como, para os ouvintes, as vozes das canções criam sempre a impressão de que o sujeito de fato fala de si, à revelia de todos os meandros do processo de composição, produção e arranjo. Essa dupla remissão ao sujeito operada pelo aparelho enunciativo e pelo substrato vocal do intérprete é recorrente. Em comentário sobre a assim chamada "enunciação do

\footnotetext{
${ }^{9}$ Cf. Cap. 1, p. 23.

${ }^{10}$ Cf. Seção. 1.2.1, p. 19 ss.

${ }^{11}$ Essa ideia de comprometimento com o que é dito se mostra particularmente decisiva na análise de textos falados em geral e, com especial ênfase em p. 159 ss. em particular.
} 
cancionista", reincidem evidências que corroboram essa concepção, ainda que despida em grande medida do jargão da área:

Claro que não preciso dizer 'eu' literalmente para me fazer sentir como enunciador do texto. Quando digo 'você', 'tu', 'o senhor' ou qualquer outro indício de que me dirijo a alguém (imperativos, demonstrativos, nomes próprios etc.), imediatamente me instalo como 'eu', já que ninguém pode se dirigir ao outro sem estar presente. E quando o texto é oral (ou cancional), pela participação do corpo do enunciador (como num show), no mínimo pela atuação da voz (como num disco). (Tatit, 2014, p. 312)

A um estudo semiótico, o que interessa é sobretudo esse efeito de sentido de autenticidade gerado pela identificação entre o sujeito do enunciado construído na letra e o sujeito encarnado pelo revestimento timbrístico da voz (Tatit, 1986 ,p. 9-11). ${ }^{12}$ A fusão desses dois sujeitos em um único, corporalizado pelo timbre, evidencia seu comportamento como marcador enunciativo de pessoa, análogo aos dêiticos da língua natural. Para resgatar as formulações pioneiras de Benveniste (2006 [1974]), a relação "constante e necessária" com a enunciação ${ }^{13}$ se impõe já no próprio lastro timbrístico da voz no enunciado.

\subsubsection{Condicionantes da breagem sensível}

A adequação e a coerência dessa proposta precisa, contudo, tomar em consideração uma distinção fundamental. Ao contrário do que ocorre com o aparelho enunciativo na linguagem verbal, forçosamente idêntico para todos os falantes, a debreagem sensível desencadeada pelo timbre exige por parte do enunciatário uma operação de reconhecimento, que pode estar sujeita a variações de ordem individual.

No primeiro caso, não há margem para diferenças de interpretação de falante para falante. Recuperando um exemplo já apresentado anteriormente ${ }^{14}$, um enunciado como "Eu sei que vou te amar" comporta sempre e necessariamente uma debreagem enunciativa de pessoa, desencadeada pelos pronomes pessoais "eu", "te" e pela conjugação de primeira pessoa dos verbos "sei" e "vou" - indiferentemente aos que ocupam a posição de enunciador e enunciatário em cada caso particular. Essas operações enunciativas funcionam de igual maneira para todo e qualquer falante.

Algo distinto se passa com a debreagem sensível desencadeada pelo timbre. Em grande medida, ela depende do reconhecimento de uma identidade particular iconizada

\footnotetext{
${ }^{12}$ Cf. Cap. 1, p. 19 ss.

${ }^{13}$ Cf. Seção 5.2.1, p. 147 acima.

${ }^{14}$ Cf. p. 148 acima.
} 
pelo timbre - reconhecimento esse que não ocorre de maneira uniforme em todas as situações. Ao contrário, ele está sujeito a variações em função do enunciatário e seu fazer interpretativo. Para uns, o timbre pode iconizar um sujeito inequivocamente particular ao passo que, para outros, ele remete apenas a uma identidade inespecífica. ${ }^{15}$ Para mostrar a importância dessa questão da identificação, bem como sua variabilidade no caso do timbre, convém recuperar e reavaliar de maneira pontual aspectos específicos da noção de embreagem conforme conceptualizada e divulgada em trabalhos da área:

A embreagem actancial diz respeito à neutralização na categoria de pessoa. Toda embreagem pressupõe uma debreagem anterior. Quando o presidente diz 'O presidente da República julga que o Congresso Nacional deve estar afinado com o plano de estabilização econômica', formalmente temos uma debreagem enunciva (um ele). No entanto, esse ele significa $e u$. Assim uma debreagem enunciativa (instalação de um $e u$ ) precede a embreagem, a saber, a neutralização da oposição categórica eu/ele em benefício do segundo membro do par, o que denega o enunciado. (Fiorin, 1999, p. 48)

Explanações como essa pretendem didatizar o funcionamento do aparelho formal da enunciação, nomeadamente no que concerne à categoria de pessoa. No entanto, da maneira como colocada, permanece ainda não explicado um dado imprescindível para o desencadeamento da embreagem: de antemão, é preciso saber que o enunciado foi proferido por um sujeito identificado como presidente da República. O efeito de sentido apresentado pelo autor depende necessariamente da coincidência entre o sujeito da enunciação e o sujeito referido no enunciado pela expressão nominal "presidente da República". Nesse ponto, é legítimo se questionar sobre a fonte de evidência dessa informação. Ela deve ser assumida como conhecimento enciclopédico prévio partilhado pelos sujeitos? São pistas contextuais (visuais, gestuais, sonoras etc.) da interação verbal que permitem chegar a essa conclusão? Qualquer que seja a resposta, esse dado é o elo imprescindível para o "bom funcionamento" da embreagem como tal. Outras evidências presentes na literatura semiótica corroboram o papel central dessa operação de identificação para o desencadeamento dessas operações enunciativas.

O verbete "embreagem" do Dicionário de Semiótica (Greimas \& Courtés, 2012 [1979]) menciona que há, nessa operação, um conjunto de procedimentos que, mesmo implícitos, "visam produzir um efeito de identificação* entre o sujeito do enunciado e o sujeito da enunciação" (2012 [1979],p. 160). Nessa passagem, um detalhe aparentemente secundário fornece uma pista decisiva. No texto original (conforme reproduzido ipsis litteris aqui), o termo "identificação" é acompanhado de um asterisco, sinal tipográfico

\footnotetext{
${ }^{15}$ Cf. Cap. 2.
} 
convencionalizado pelos autores para indicar que o metatermo assinalado conta também com uma entrada própria na obra. Não é o que acontece, contudo, com esse termo especificamente. Em lugar dele, encontra-se o verbete "identidade". Sua segunda acepção fornece evidências suplementares para entender essa questão da identificação e seu papelchave no comportamento enunciativo do timbre:

\begin{abstract}
Desse ponto de vista, a identificação é uma operação metalinguística que exige, anteriormente, uma análise sêmica ou fêmica: longe de ser uma primeira abordagem do material semiótico, a identificação é uma operação, entre outras, de construção do objeto semiótico. (Greimas \& Courtés, 2012 [1979], p. 252; verbete "identidade", §2, grifos nossos)
\end{abstract}

Eis aqui, já presente no pensamento greimasiano, os fundamentos para entender como se dá o reconhecimento de entidades por trás do timbre e como esse processo depende forçosamente de uma análise prévia por parte do sujeito. ${ }^{16}$ Isso significa dizer que, em um primeiro contato com o material timbrístico, a identificação de sua fonte sonora será gravemente comprometida. Nesse caso, o timbre apenas dificilmente poderá desencadear um engate enunciativo. Assim sendo, coloca-se como condição imprescindível para tal um investimento semântico e figurativo prévio mínimo. ${ }^{17}$

\title{
5.3 Relações de (in)compatibilidade entre revestimento tímbrico e substrato linguístico/musical
}

Seguindo essa linha de raciocínio, avançaremos então na hipótese de que a sobreposição das componentes timbrística e linguístico-musical resultará em novos efeitos de sentido não previstos inicialmente pelo segundo por si só. A questão pode ser apresentada da seguinte maneira: os timbres selecionados para revestir o enunciado (seja ele verbal, cancional ou musical) reafirmam ou contradizem seus mecanismos enunciativos? Trata-se, no fundo, de discutir a plausibilidade de vislumbrar distintos graus de compatibilização entre um substrato (linguístico, melódico, harmônico etc.) e seu respectivo revestimento timbrístico. Isso implica admitir que a própria configuração linguística e/ou musical do enunciado sugere uma manifestação preferencial em certos timbres em detrimento de outros desfavorecidos.

\footnotetext{
${ }^{16}$ Cumpre observar que, ao colocar a análise sêmica e fêmica em pé de igualdade, a conceptualização original dos autores deixa margem de interpretação suficiente para aplicar essa noção de identificação tanto ao plano da expressão quanto ao plano do conteúdo.

${ }^{17}$ Cf. Cap. 2.
} 
De certo modo, esse fenômeno já tinha sido detectado por Carmo Jr. (2007) quando discute o assim chamado "simulacro de interpretação no imaginário do compositor" (2007 ,p. 144). ${ }^{18}$ Na mesma direção, Mancini (2005,p. 104) também nota que, em certa medida, o intérprete da canção popular está subordinado às possibilidades précircunscritas pelo compositor. A ideia de que uma dada composição nasce "predestinada" a uma manifestação timbrística preferencial aparece com mais ênfase como pano de fundo de toda a discussão conduzida em Coelho (2004, 2007) sobre os processos de rearranjo na canção popular brasileira. Não seria desmensurado afirmar que todas essas proposições remontam à premissa fundamental de que o andamento-base da canção se encontra de certa forma já cifrado em estado de latência no projeto enunciativo ${ }^{19}$ da canção:

Todas as possibilidades oscilatórias entre tensões temáticas e tensões passionais, bem como o processo de desativação dessas tensões, estão inscritas, de algum modo, no seu projeto enunciativo. Quando ouvimos diferentes execuções de uma mesma composição, entramos em contato com diferentes interpretações do mesmo projeto geral criado pelo cancionista. (Tatit, 1997, p. 122, grifos nossos)

Os destaques se devem aqui ao caráter de antecipação embutido na ideia de "projeto". Sem abusar do argumento etimológico, a ideia de um elemento anterior (pro) que se arremessa (do latim, jactum) fornece uma evidência suplementar de que os enunciados verbais-cancionais-musicais comportam em si pistas que antecipam sua manifestação timbrística ótima. Os diferentes graus de explicitude e força coercitiva dessas indicações resultarão em diferentes níveis de compatibilidade entre substrato linguístico-musical e revestimento timbrístico, que se deixam resumir a três cenários básicos.

No primeiro cenário, essas duas instâncias contraem elos fortes de compatibilização. Aqui, o subtrato linguístico-melódico é manifestado por seu revestimento timbrístico preferencial. Da sobreposição ótima desses componentes resultam efeitos de sentido de autenticidade e de veracidade. O segundo cenário é o simétrico oposto do primeiro. Substrato linguístico-musical e revestimento timbrístico se mostram flagrantemente incompatíveis entre si. Essa discrepância força o enunciatário a reconfigurar seu fazer-interpretativo e buscar outras maneiras de interpretar o enunciado como aceitável. O terceiro cenário é, de certa forma, uma suspensão dessa oposição. Nem favorecidas, nem desfavorecidas, as relações entre revestimento timbrístico e substrato linguístico-musical são indiferentes entre si e contraem uma relação de livre variabilidade. São fracos os elos entre essas duas

\footnotetext{
${ }^{18}$ Cf. também acima Cap. 1, p. 21 ss.

${ }^{19}$ Cf. subseção 1.2 .2 , p. 22. Observe-se de passagem que essa noção de "projeto enunciativo" já tem sido empregada com êxito nos trabalhos sobre o fenômeno das traduções intersemióticas conduzidos por Renata Mancini (2014, 2018, 2019a,b).
} 
instâncias e suas restrições combinatórias são neutralizadas. Esse cenário corresponde àquela concepção de timbre como elemento de "livre projeção" sem determinação prévia. ${ }^{20}$

Assim delineada, essa distinção traz o benefício de mostrar que a livre variabilidade do timbre é apenas um dos quadros previstos, e não o único possível. Vislumbradas essas possibilidades teóricas de compatibilização entre timbre e subtrato linguístico-musical, cumpre agora explorar casos concretos de ocorrência na fala, na canção e na música.

\subsubsection{Fala}

Ao contrário do que presume o senso comum, a designação "fala" não se atém apenas à conversação cotidiana, mas inclui também uma ampla gama de manifestações orais que abrange desde o marketing telefônico até o discurso político, passando pela publicidade radiofônica e pela dublagem de filmes e jogos. Cada qual a seu modo, todos esses cenários fornecem evidências concretas do funcionamento do timbre como debreagem sensível, corroborando ou contradizendo o comportamento enunciativo do componente verbal propriamente dito. De agora em diante, desdobraremos as decorrências práticas da premissa de que, como extensão metonímica do corpo do sujeito, o timbre de voz tem propriedades enunciativas análogas ao sistema dêitico das línguas naturais.

\section{Um novo olhar sobre a embreagem}

Para iniciar a investigação, é conveniente resgatar um cenário já aventado acima, a saber, a identificação entre sujeito do enunciado e da enunciação em uma sentença como "O presidente da República julga que o Congresso Nacional deve estar afinado com o plano de estabilização econômica" quando proferido pelo próprio presidente da República. ${ }^{21}$ Esse caso específico ilustra a embreagem em um texto escrito por meio de um exemplo fictício e $a d-h o c$, sem maiores detalhes sobre sua realização em modalidade oral ou escrita da língua. Agora é o momento de recolocar, dessa vez com maior veemência, a seguinte pergunta: como é possível se assegurar que o enunciado em questão foi de fato proferido pelo presidente da República? Que fonte de informação nos provê essa evidência? O que parece ser um detalhe apenas secundário na definição do conceito é, na verdade, decisivo para quem se propõe a observar o comportamento enunciativo do timbre, pois é ele que serve de gatilho para a operação de identificação dos sujeitos.

É o que ocorre com entrevistas radiofônicas, em que o único canal sensorial de manifestação do texto é o auditivo. Demonstremos esse fato por meio de um caso concreto, extraído de entrevista realizada pelo jornal Folha de São Paulo em 30 de Agosto de 2000. ${ }^{22}$

\footnotetext{
${ }^{20}$ Cf. Cap. 1, p. 15.

${ }^{21}$ Cf. p. 154 acima.

${ }^{22} \mathrm{O}$ arquivo sonoro está disponível publicamente por hiperlink da internet (Folha de São Paulo, 2000a).
} 
Da totalidade do texto sonoro, gostaríamos de destacar o trecho entre 0:12 e 0:25 segundos da gravação transcrito abaixo: ${ }^{23}$

Voz 1: Como o senhor vê uma campanha que está sendo desenvolvida pela $[\mathrm{ONG}]$ "Transparência contra o 'rouba, mas faz'" ?

Voz 2: Eu acho que todos os outros catorze candidatos deveriam protestar, porque o Maluf fez muito. Fez mais do que todos. Tá [sic!] há trinta e três anos na vida pública, não tem nenhuma condenação transitado em julgado, nenhuma $[\ldots]$

Na resposta proferida pela segunda voz, verifica-se de início uma debreagem enunciva de pessoa, atestada nas expressões nominais ("Maluf") e nos verbos flexionados na terceira pessoa ("fez", "está", "tem"). Nesse contexto, a ativação da embreagem depende forçosamente do reconhecimento da identidade do político Paulo Maluf por trás do timbre da segunda voz. É a sobreposição do revestimento timbrístico de Maluf sobre esse substrato linguístico, notadamente a expressão "o Maluf" 24 , que corrobora esse efeito de sentido. Idêntico efeito é verificado também em entrevista com Edson Arantes do Nascimento, ao referir-se a si mesmo usando, aliás, dois antropônimos distintos.

Jornalista: E o Edson Arantes do Nascimento é um homem realizado?

Edson Arantes do Nascimento: Sem dúvida é um homem realizado ... eu até brinco e falo assim: 'Edson era antes do nascimento, agora é Pelé, ninguém quer saber do Edson'. (Rede Globo, 2018, 09'50" - 10'10", destaques nossos)

Pode-se generalizar e sintetizar tais achados da seguinte forma: em textos orais, a embreagem de pessoa é desencadeada pela sobreposição particular entre revestimento timbrístico e substrato linguístico remetendo ambos ao mesmo sujeito. De maneira simétrica e inversa, a divergência entre essas duas instâncias desencadeia uma debreagem enunciva de pessoa. Para que o mecanismo de breagens seja acionado, o reconhecimento timbrístico deve disparar algum gatilho já instalado no componente verbal do enunciado.

Cumpre ressaltar que tal reconhecimento depende, por sua vez, de certas condicionantes prévias. É preciso não apenas saber de antemão quem é o sujeito por trás da voz, mas também poder reconstituí-lo por meio de seu timbre. ${ }^{25}$ A ausência de pistas

\footnotetext{
${ }^{23}$ Mais informações circunstanciais sobre a entrevista podem ser obtidas na reportagem escrita (Folha de São Paulo, 2000b).

${ }^{24}$ Sobre a sobreposição de antropônimos e timbres específicos, cf. p. 172 adiante e Seção 2.6, p. 64.

${ }^{25}$ Cf. Cap. 2.
} 
paralinguísticas suplementares (visuais, gestuais etc.) para o reconhecimento da identidade do sujeito alça o timbre a uma posição de privilégio nesse processo.

\section{Propaganda eleitoral}

A relevância desse fenômeno semiótico é de tal monta que pode até mesmo chegar a motivar processos judiciais. É o que ocorreu nas eleições presidenciais do Brasil em 2018. Uma das peças-chave da controversa disputa girava em torno da impugnação da candidatura de Luiz Inácio Lula da Silva, que, até então, liderava com ampla margem de intenções de voto (cf. Deutsche Welle, 2018). A decisão judicial concernia não apenas à candidatura propriamente dita, mas também à restrição à presença de Lula a apenas $25 \%$ do tempo reservado ao partido na campanha (cf. Carta Capital, 2018). Sobre esse pano de fundo conjuntural, o jingle de campanha intitulado "É o Brasil feliz de novo" (Partido dos Trabalhadores, 2018) coloca questões interessantes para pensar o funcionamento enunciativo do timbre. Após um minuto e dezesseis segundos de gravação, ouve-se, interpolada pelos versos do jingle, a seguinte frase declamada em prosódia coloquial pelo timbre de Lula: "Os poderosos podem matar uma, duas ou três rosas, mas jamais conseguirão deter a chegada da primavera". ${ }^{26}$

No caso em tela, interessam menos as isotopias temáticas e figurativas instaladas no plano verbal - bem como suas possíveis leituras alegóricas - do que sua manifestação em um revestimento timbrístico específico. É a assunção dessas palavras por esse sujeito específico que confere seu poder conclamativo, remetendo à reflexão de Tatit (2016) sobre o assim chamado comprometimento do sujeito com seu dizer. ${ }^{27}$ Para garantir sua força perlocutória, não basta que esse verso seja proferido por um timbre incógnito, tomado a esmo dentre tantos locutores profissionais aptos a tal ofício; é preciso, acima de tudo, que sua carne timbrística remeta a um sujeito específico, já infundido de uma série de inclinações temáticas, figurativas e passionais recuperáveis interdiscursivamente. ${ }^{28}$

A esse respeito, é pouco relevante elucubrar se o sujeito de "carne-e-osso" que realizou a gravação é ontologicamente Luiz Inácio Lula da Silva. De um ponto de vista imanentista, a questão central é que esse sujeito seja metonimicamente iconizado pelo timbre da gravação sonora. Um eventual uso de sósias vocais ou de imitadores desencadearia esse processo de igual maneira.

Voltando para o contexto conjuntural, é preciso notar que qualquer decisão acerca dessa peça publicitária passa obrigatoriamente pela questão da iconização do sujeito-Lula

\footnotetext{
${ }^{26} \mathrm{O}$ áudio está disponível publicamente por hiperlink da internet.

${ }^{27}$ Cf. p. 152 acima.

${ }^{28}$ Sobre a constituição da identidade timbrística da voz de Lula, seu uso em contexto político e sua significação, recomendamos enfaticamente os trabalhos de Piovezani (2011, 2014, 2017) sob a perspectiva da Análise do Discurso, bem como a reflexão ensaística de Ab’Saber (2012).
} 
pelo revestimento timbrístico dos versos em destaque. O mérito semiótico da discussão independe da deliberação a favor ou contra: o fato mesmo de que esse jingle tenha sido objeto de disputa judicial já é prova da relevância e do impacto causado pela relação insólita entre um um revestimento timbrístico minuciosamente escolhido e um substrato linguístico apropriado.

Também é digno de nota que o timbre por si só não teria talvez os mesmos efeitos, uma vez que um substrato linguístico aleatório poderia tornar a escolha timbrística até mesmo irrelevante. É a combinação idiossincrática entre o revestimento timbrístico de Lula e o substrato linguístico, aludindo a valores como coletividade e esperança, que motivou seus adversários eleitorais a reivindicar a suspensão dessa peça publicitária. Vale frisar que, a despeito das isotopias temáticas e figurativas, esses versos não portam qualquer ancoragem enunciativa além do timbre. Fica então a encargo do enunciatário efetuar seu fazer interpretativo que, se positivo, reconhecerá o sujeito-Lula.

\section{Áudiovisual e locução voice over}

Esse poder persuasivo do timbre como gatilho de identificação é empregado em toda sorte de textos audiovisuais, tais como publicidade radiofônica, vinhetas televisivas, filmes, seriados entre outros. De maneira análoga ao uso de rostos célebres em anúncios impressos e audiovisuais, a publicidade em meio sonoro se vale da notoriedade dos timbres de voz empregados com o objetivo de conferir credibilidade junto ao público. ${ }^{29}$ Essa questão-chave pode ser colocada algo intuitivamente da seguinte maneira: por que optar por determinada voz célebre ao invés de outra anônima? A resposta reside no grau de densidade figurativa prévia investido no timbre. Assim sendo, não basta que o componente verbal do enunciado esteja modelado para a manipulação - usando esse termo em sua acepção semiótica estrita -, é preciso também que ele seja otimizado por meio da sobreposição por um revestimento timbrístico particular.

Semelhante caso verifica-se na vinheta intitulada "O conto da Marca", lançada pela Rede Globo (2019). Ao longo de seus sessenta segundos de duração, uma trilha puramente musical acompanha um espetáculo que sincretiza dança, luzes, cenografia e efeitos de computação gráfica. Aos quarenta e um segundos, ouve-se uma voz narrando o seguinte texto: "A vida está em movimento. O mundo está em movimento. Você está em movimento. A Globo está em movimento para acompanhar a vida, o mundo e você". Nessa narração, não é fortuito reconhecer o timbre de William Bonner, apresentador da emissora em questão desde 1986 e desde 1996 à frente do noticiário "Jornal Nacional". Tal escolha contribui decisivamente para instaurar o tom institucional do filmete. Mais uma vez, fica a encargo do enunciatário reconhecer, por trás da voz, a identidade do sujeito e

\footnotetext{
${ }^{29}$ Cf. Seção 5.4.4.
} 
extrair daí todas suas possíveis decorrências.

No domínio do audiovisual, esse expediente é conhecido usualmente como "voz over". Nele, uma locução se sobrepõe às imagens na tela para criar o efeito de narrador em primeira pessoa (Xavier, 2017). Ainda segundo essa mesma fonte, tal recurso pode ser considerado, guardadas as devidas proporções, como equivalente cinematográfico da instalação do "eu" na literatura escrita. Em entrevista concedida ao canal virtual do periódico acadêmico Significação, o autor assim sintetiza:

[...] Nesses filmes narrativos que a gente conhece, é difícil você encontrar a construção disso [narrador em primeira pessoa] apenas visualmente. Há filmes experimentais que trabalham com a construção de um narrador em primeira pessoa apenas com posições de câmera. Mas, assim, os filmes narrativos dramáticos que são filmes de ficção e que são aqueles que a gente assiste em geral no cinema, mesmo aqueles mais complexos, são filmes que, em geral, para definir que há uma primeira pessoa, existe [sic!] uma voz" (Xavier, 2017,4 '18" - 4'50")

Essa técnica é empregada para demarcar a convergência entre sujeito-narrador e sujeito da narrativa. Esse sincretismo actancial corresponde ao que se designa corriqueiramente como narrador-personagem. ${ }^{30}$ Tal pareamento timbrístico dessas duas instâncias é um recurso bastante produtivo para criar um efeito de sentido de narração memorial. São abundantes as ocorrências que atestam a produtividade desse expediente.

Do cinema nacional, merece destaque aqui o filme Tropa de Elite (2007), em que os fatos da narrativa apresentados na tela são comentados e avalizados em tom memorial pela voz de Wagner Moura, que também desempenha o papel do protagonista Capitão Nascimento (1'10"-4'30" e 6'30"-7'00"). Não por acaso, o Ministério da Justiça escolheu, mais tarde, empregar seu timbre para protagonizar a locução de vídeos e spots de rádio da Campanha Nacional do Desarmamento lançada no país em maio de 2011 (Portal Brasil, 2011). A força persuasiva dessa estratégia se deve em grande medida à remissão à truculência física e ao temperamento violento pelo timbre que interpela o ouvinte-espectador. Do cinema de entretenimento, pode-se mencionar as cenas iniciais do primeiro filme da trilogia Homem-Aranha (2002), nas quais escuta-se uma voz over que poderá logo em seguida ser reconhecida como a voz do protagonista Peter Parker. Passando ao universo dos seriados em plataformas virtuais, esse mesmo expediente pode ser encontrado na produção espanhola La casa de papel (2017), em que a personagem

\footnotetext{
${ }^{30}$ Cf. Xavier (2000) sobre efeitos estéticos mais complexos decorrentes desse recurso na linguagem cinematográfica.
} 
codinominada "Tóquio" re-narra o desenrolar de um assalto à casa da moeda de que tomou parte.

$\mathrm{Na}$ esteira de suas contrapartes mais realistas, as animações também se valem ostensivamente desse recurso. Na produção em longa metragem 300 de Esparta (2007), é pela identidade timbrística que sabemos que a narrativa é rememorada pelo protagonista Leônidas. Em A nova onda do imperador (2000), o texto que introduz as linhas gerais do enredo é narrado pela mesma voz do personagem principal. Na produção Enrolados (2011) dos estúdios Disney, as cenas de abertura e fechamento são narradas pelo mesmo timbre de voz de um dos protagonistas (Flynn Rider). Também a animação Persépolis (2008) lança mão desse expediente para instalar a protagonista Marianne no epicentro da narração.

Para os fins aqui pretendidos, não é necessário delongar essa lista de ocorrências, que poderia virtualmente se estender ao infinito. Os casos apresentados bastam para evidenciar como a projeção de um revestimento timbrístico sobre um substrato linguístico dado não é aleatória; ao contrário, ela pode funcionar como um mecanismo orgânico de instalação do narrador em enunciados audiovisuais.

\section{Dublagem}

Sobre esse pano de fundo, pode-se tratar também a dublagem como fenômeno análogo. Diferenças de arquitetura narrativa à parte, ambos os procedimentos demonstram casos em que a seleção timbrística não é acidental, mas sim contribui para a co-construção figurativa dos atores do enunciado. Não é por acaso que a célebre cantora Dalva de Oliveira foi eleita em 1937 para emprestar sua voz à Branca de Neve naquela que foi a primeira produção dublada no Brasil (cf. O Estado de São Paulo, 2018). Realizada de maneira algo intuitiva pelos profissionais da área, essa escolha é regida por um processo de compatibilização ótima ${ }^{31}$ entre o personagem (incluindo aí todo o complexo de sua configuração narrativa, passional e figurativa) e o timbre que deverá receber na versão dublada.

Uma evidência disso é a forte reação negativa do público à mudança timbrística na dublagem de um dado ator e/ou personagem. Motivações de ordem comercial à parte, tais trocas são mal-recebidas tanto por produtores quanto pelo público devido a seus efeitos negativos de descontinuidade (cf. News, 2016; JWave, 2016). Desse modo, contornando coerções de natureza material, estúdios e produtoras se empenham para garantir a uniformidade timbrística das versões dubladas. Essa prática é testemunhada pela dubladora profissional Mabel Cezar ao comentar sobre as personagens a quem empresta sua voz: "Também colocam minha voz nos brinquedos e em outros equipamentos

\footnotetext{
${ }^{31}$ Essa compatibilização é uma forma de typecasting, cf. Seção 5.4.4, p. 193 adiante.
} 
eletrônicos. Tudo o que inventarem da Disney, que tenha Minnie, a Jessie ou a Princesa Leia, sou eu que estou ali dublando, em todos esses projetos." (O Estado de São Paulo, 2019 , C3). Como se pode ver, a uniformização timbrística é essencial para assegurar certa coerência figurativa na construção desses personagens.

Outra manifestação do timbre de relevância semiótica no universo da dublagem é o recurso, frequentemente visto como controverso, a vozes de celebridades em detrimento de dubladores profissionais com formação técnica específica. Isso ocorre sobretudo devido ao forte apelo mercadológico proporcionado pela notoriedade pública dos timbres em questão e seus respectivos donos. Avaliações valorativas à parte, é interessante observar como a pregnância do timbre tem tanto peso nessa escolha quanto o treinamento técnico do dublador. De um ponto de vista propriamente semiótico, pode-se dizer que entra em jogo nessa decisão algo como uma "transferência de éthos" nesse empréstimo de voz a um personagem.

É por sua espessura semântica prévia que o timbre de uma celebridade tem maior potencial de enriquecimento figurativo em comparação com outra voz anônima, a despeito de toda flexibilidade técnica desta última. Não é casual, portanto, a escolha da voz do humorista Bussunda para a dublagem do personagem Shrek do longa-metragem animado de mesmo nome (2001), do piloto de Fórmula 1 Rubens Barrichello para a dublagem do personagem Cal Weathers na animação Carros 3 (2017), bem como do humorista Fábio Porchat para o personagem Olaf da animação Frozen - uma aventura congelante (2013), apenas para mencionar alguns casos emblemáticos do circuito comercial (UOL, 2018, 2016). Esse recurso é decisivo no caso das animações gráficas, que dependem inescapavelmente do empréstimo da voz de outrem.

No caso de produções audiovisuais voltadas ao público infantil, a singularização timbrística por meio de modulação vocal parece assumir importância ainda maior. Para assegurar seu efeito de autenticidade, as características idiossincráticas do personagem devem ser incrementadas com um timbre igualmente idiossincrático. Assim, faz-se preciso conferir à voz uma fisionomia timbrística inconfundível e, tanto quanto possível, atribuível exclusivamente ao personagem em questão. ${ }^{32}$

Disso pode-se concluir que o revestimento timbrístico escolhido para dar carne e corpo às palavras do personagem promove um sincretismo de atores que extrapola os limites do texto-enunciado propriamente dito e estabelece pontes intertextuais e interdiscursivas. Não é demasiado ressaltar que a seleção desses revestimentos timbrísticos se torna absolutamente inócua caso o sujeito-enunciatário não os reconheça. Reafirma-se, assim, o papel decisivo do fazer-interpretativo na produção desses efeitos de sentido.

\footnotetext{
${ }^{32}$ Apenas para arrolar alguns personagens anedóticos, pode-se mencionar Pato Donald (Disney), Zé Colméia (Hannah-Barbera), Bob Esponja (Nickelodeon), Quico (Televisa) entre outros.
} 


\section{Conversas telefônicas e trote do falso sequestro}

Tal espessura semântica e figurativa está por trás de outro fenômeno que, embora bastante corriqueiro na vida cotidiana, evidencia com clareza ímpar a pertinência semiótica e a relevância social do timbre. Quando reconhecemos um interlocutor familiar em um mero "alô" ao telefone, presumimos dele uma miríade de informações sobre sua identidade e sobre os saberes e valores que com ele partilhamos. Em um brevíssimo lapso de tempo, tomamos uma série de decisões a respeito de como encaminhar a conversação, evitando resvalar em contribuições irrelevantes de um ponto de vista pragmático (isto é, já dadas como pressupostas por esse saber partilhado comum ${ }^{33}$ ). Mesmo o uso de softwares identificadores de chamada, onipresentes nos aparelhos celulares dos dias atuais, não invalida a pregnância semiótica do timbre nas conversas telefônicas. Uma eventual divergência entre o que o identificador informa e o timbre escutado ao telefone certamente suscitaria desconfiança no sujeito, impelindo-o a replanejar todos os rumos futuros dessa interação verbal.

Sobre esse pano de fundo, um cenário-chave para o estudo semiótico do timbre é o assim chamado golpe do falso sequestro. Apenas para contextualizar em termos gerais, trata-se de uma modalidade de extorsão aplicada por ligação telefônica, na qual encena-se o sequestro de um familiar do interlocutário (cf. Câmara Municipal de Extrema, s/d). Um dos elementos decisivos para garantir a força intimidatória desse tipo de golpe é a súplica por socorro feita ao telefone por uma voz atribuível à pessoa supostamente sequestrada.

Em tal circunstância, o timbre funciona como uma espécie de evidência material que pretende atestar a veracidade da situação encenada e conferir maior poder de intimidação. Cumpre observar que o logro do golpe depende decisivamente de uma identificação errônea do timbre por parte do enunciatário e seu fazer-interpretativo. Não por acaso, as instruções mais comuns de segurança têm como denominador comum uma espécie de "suspensão veridictória" cautelar (cf. G1 - TV Anhanguera, 2014). Manter a calma, duvidar da veracidade dos fatos, exigir outros elementos de identificação da vítima: tudo converge para a manutenção do sujeito em uma postura modal de desconfiança defensiva (/não-crer/). É o que ilustra o seguinte trecho de uma reportagem jornalística a respeito do tema:

'O ideal mesmo é a pessoa manter a calma. Eu conheço essa voz? E não falar nada, "mãe", "irmã". Não falar nenhum nome, por exemplo, Renata, João ... fica quieto. "Quem é"? "Qual é o seu nome, o que está acontecendo?" Não fala nada.

\footnotetext{
${ }^{33}$ Sem pretender complexificar desnecessariamente esse ponto, essa ideia é comparável à noção de "acordo prévio" nos estudos da argumentatividade (Fiorin, 2016, p. 90-94) e de common ground nos estudos da semântica dinâmica (Stalnaker, 1999).
} 
A pessoa mesmo vai se entregar, dizer que é um golpe', diz o humorista [Jonathan Nemer]. (G1 - Globo, 2015, grifos nossos)

Por contingente que seja, o depoimento da vítima põe em relevo justamente dois dos elementos mais salientes para ativação das breagens por timbre que colocamos em destaque no trecho acima e que viemos desenvolvendo no presente trabalho, a saber, o reconhecimento do timbre e os nomes próprios. ${ }^{34}$ Quando recomenda exigir do interlocutor identificações verbais explícitas, o alerta esbarra, de maneira algo intuitiva e involuntária, na questão da interação entre revestimento timbrístico e substrato linguístico. Nesse cenário, somente a sobreposição entre essas duas instâncias chancelaria de fato a identidade do sujeito supostamente sequestrado por trás da voz.

O golpe do falso sequestro mostra como o timbre é um dado de natureza eminentemente semiótica. O ludíbrio sonoro só é possível graças a certa pré-disposição por parte da vítima à credulidade (querer-crer) - tomando esse termo sem qualquer insinuação pejorativa. O cerne de tal fenômeno se constitui, portanto, menos de ondas acústicas do que das certezas, incertezas e recusas esteadas no universo cognitivo do sujeito (Greimas, 2014 [1983] , p. 115-126).

\section{Identidade timbrística incerta: áudios vazados}

Voltando ainda ao contexto conjuntural das eleições de 2018 no Brasil, outros casos vieram à tona que mostram as decorrências concretas dessa operação de reconhecimento de timbres. Dentre os inúmeros episódios relacionados à propagação de notícias falsas naquela ocasião, ganhou destaque a difusão, pela internet e por redes sociais, de mensagens de áudio com autoria falsamente atribuída a personalidades do contexto sócio-político brasileiro. A despeito de detalhes idiossincráticos de cada episódio particular, todos eles orbitam em torno de um epicentro comum, a saber, a interação entre a semântica do substrato linguístico e o sujeito (supostamente) identificado por seu revestimento timbrístico.

Durante a corrida eleitoral daquele ano, foi publicamente atribuída ao Padre Marcelo Rossi uma gravação sonora declarando apoio ao então candidato Jair Bolsonaro. Poucos dias depois, a autoria dessa mesma mensagem foi creditada ao Padre Fábio de Mello, até ser enfim reivindicada por Rinaldo Seixas Pereira, também conhecido como Apóstolo Rina da igreja Bola de Neve (cf. Jornal Folha de São Paulo, 2018b,a). É preciso frisar que, no substrato linguístico dessa gravação, não há nenhuma expressão (nominal ou pronominal) que autorreferencie o falante e possa, assim, identificá-lo. Tal fato foi

\footnotetext{
${ }^{34}$ Cf. Cap. 2.
} 
utilizado pelas agências de checagem do projeto Comprova ${ }^{35}$ como uma das evidências da falsidade do boato.

A mesma instituição agiu também para desmentir a falsa atribuição de autoria a Fernando Haddad e Manuela D'Ávila de uma gravação sonora difundida na internet, na qual é criticada a crescente interferência do exército brasileiro nas decisões políticas. Conforme revelado por apuração jornalística (cf. UOL Confere, 2018), a voz masculina do áudio em questão de fato é de Fernando Haddad; porém, a voz feminina é na verdade de Débora Bergamasco, jornalista da emissora televisiva SBT. Segundo a mesma fonte, o diálogo em questão foi extraído e descontextualizado de uma sabatina realizada conjuntamente pelos veículos Folha de São Paulo, UOL e SBT com os então candidatos à presidência (cf. UOL Mais, 2018). Vale notar aqui que a verossimilhança do boato se apoia em uma distorção apenas parcial. Enquanto a identidade de Fernando Haddad por trás de sua voz permanece intocada, falseia-se a identidade de Manuela D'Ávila por trás da voz feminina do áudio.

Semelhante episódio envolveu também o jornalista e âncora da Rede Globo Chico Pinheiro, a quem foi atribuída a autoria de uma gravação em áudio que toma partido do ex-presidente Lula, critica a atuação do juiz Sérgio Moro na operação Lava-Jato, bem como o viés da cobertura jornalística da própria emissora em que trabalha. Da mesma forma, a polêmica passa pela questão do reconhecimento da identidade do sujeito por trás da voz. O teor semântico do substrato linguístico por si só é menos controvertido do que sua manifestação em um timbre específico - nesse caso, o de um reputado jornalista da emissora televisiva de maior cobertura no país (cf. Negócios - Globo, 2015). Note-se que a identificação desse timbre a um sujeito qualquer, sem proeminência pública, tornaria inócua toda a disputa em torno dessas declarações.

Para recolocar a questão em termos semióticos, a polêmica gerada em todos esses casos remete, no fundo, à questão da identidade do sujeito por trás da voz e, portanto, ao baixo grau de especificação semântica do timbre. É a indeterminação timbrística que abre margem para dubiedades na atribuição de autoria e, por consequência, para toda sorte de inferências derivadas a partir daí. Em certa medida, pode-se considerar tais fenômenos como a situação simétrica e inversa do que se apresenta no jingle eleitoral com a voz de Lula analisado acima. ${ }^{36}$ Neste, a força perlocutória do enunciado se apoiava na alta espessura figurativa do timbre do então presidenciável, reconhecível sem o auxílio de pistas verbais. Tudo se passa como se a própria carne timbrística dos versos carregasse

\footnotetext{
${ }^{35}$ Comprova é um projeto colaborativo encabeçado pela ABRAJI (Associação Brasileira de Jornalismo Investigativo) e executado por uma coalizão de 24 organizações de mídia brasileiras com o objetivo de identificar, checar e combater rumores, manipulações e notícias falsas. Mais informações sobre o tema podem ser encontradas em: <https://projetocomprova.com.br/>

${ }^{36}$ Cf. p. 159 acima.
} 
"por si só" algo como uma carga ética e afetiva prévia, ao contrário dos outros casos, em que a rarefação figurativa do revestimento timbrístico dos áudios abre margem para a falsa atribuição de autoria.

\section{Timbre e anonimato}

A polêmica dos áudios vazados só é possível devido à margem de dúvida deixada em aberto por certa subespecificação dos timbres em questão. No entanto, seria falacioso inferir a partir daí que a rarefação figurativa do timbre em si é problemática ou uma falta a ser reparada. Ao contrário, há certas situações em que essa indeterminação é desejável. A esse respeito, é legítimo se perguntar: o que motivaria a escolha por timbres indistintos e de pouca densidade figurativa?

Um caso corriqueiro pode ser encontrado em sistemas de anúncios sonoros em estações de metrô, trem e aeroportos, bem como com todo tipo de gravação automatizada em serviços de atendimento telefônico ao cliente. Nesses cenários, um timbre desnecessariamente idiossincrático acabaria por criar efeitos de sentido suplementares indesejáveis. Idealmente, o revestimento timbrístico deve ser, tanto quanto possível, desinvestido de semantismos prévios que possam inadvertidamente obliterar a força perlocucional do enunciado . Assim sendo, o timbre deve, em princípio, iconizar um "sujeito sem qualidades" e destituído de traços particularizantes, a despeito do contraexemplo apresentado pela gravação de timbres de celebridades, como o humorista Fábio Porchat (Band - UOL, 2016a) e o ator Morgan Freeman (Band - UOL, 2016b), em comandos vocais de aplicativos móveis de navegação urbana.

Outro cenário de consequências materiais mais palpáveis é o apagamento proposital da identidade de um denunciante ou testemunha com o intuito de proteger seu anonimato. Nas reportagens investigativas audiovisuais, são dois os recursos mais usuais para tal: a ocultação do rosto e a distorção da voz do sujeito por meio de máscara acústica. Essa é uma evidência concreta de que, no processo de reconhecimento de indivíduos, o timbre assume magnitude semiótica comparável à do rosto, região corporal que consabidamente concentra a maior densidade de traços identificadores da individualidade do sujeito. ${ }^{37}$

Mais do que apenas uma discussão teórica abstrata e inconsequente, esse poder de identificação da voz tem impactos concretos na vida cotidiana, podendo mesmo chegar aos tribunais. Segundo informações reportadas pelo Superior Tribunal de Justiça (STJ) em 2003, um técnico em eletrônica vence processo judicial por danos morais por ter sido exposto ao ridículo em rede aberta de televisão. Um dos argumentos utilizados em favor

\footnotetext{
${ }^{37}$ Estudos sobre os aspectos sócio-cognitivos, evolutivos e psicológicos do reconhecimento de indivíduos confirmam que o rosto como principal identificador é uma característica de humanos e primatas (cf. Pascalis, 2011). Em outras espécies, essa diferenciação individual se dá menos pelo canal visual do que pelo canal olfativo ou auditivo (cf. Sheehan \& Nachman, 2014).
} 
do réu foi a negligência da emissora em empregar os recursos de anonimização disponíveis, incluindo aí os filtros sonoros de distorção de voz (Jus Brasil, 2012). Casos como esse mostram como seria falacioso interpretar a indeterminação do timbre como uma deficiência a ser sanada. Ao contrário, também ela cumpre sua função social, que não pode ser ignorada pelo semioticista de bom senso.

\subsubsection{Canção}

Até o presente momento, a investigação se concentrou em textos orais falados. Essa etapa nos habilita a caracterizar de maneira objetiva o componente verbal do substrato linguístico-melódico da canção. Dado seu caráter de objeto sincrético por excelência, as restrições de compatibilidade com o revestimento timbrístico devem levar em consideração também o componente propriamente musical (i.e. rítmico-melódico) do enunciado. Apenas para otimizar o encadeamento da argumentação, iniciaremos expondo as coerções impostas pela letra. Em seguida, passaremos a nos ocupar com as coerções impostas pela configuração rítmico-melódica da linha do canto. Tal compartimentação se deve à necessidade de linearizar a apresentação dos resultados e não tem nenhuma outra motivação além de clareza expositiva.

\section{Letra}

Assim como visto em textos falados, debreagens e embreagens ativadas pelo timbre ocorrem também em textos cantados e demonstram de maneira categórica a compatibilização entre o revestimento timbrístico e o componente linguístico do substrato cancional. Isso ocorre devido à forte ancoragem à cena enunciativa contraída pela linguagem da canção, inevitavelmente fadada a emular uma interlocução entre um "eu" e um "tu". 38

"Meu nome é Gal" (Gal Costa) Exemplo cabal de debreagem sensível ativada pelo timbre pode ser encontrado em "Meu nome é Gal". Por meio de um interessante jogo de remissões à intérprete-narradora, o primeiro verso condensa e prenuncia toda a pregnância perlocutória dessa canção. Nele, uma debreagem enunciativa de pessoa é duplamente desencadeada pelo recurso à primeira pessoa do singular ("meu") e pelo timbre de voz de Gal Costa que, por sua vez, aparece novamente referida pelo antropônimo que encerra o verso. Assim sendo, o efeito de autenticidade da elocução deriva da convergência desses três vetores para um único ponto: Gal. Esse mecanismo de ancoragem não se restringe à expressão "Meu nome é Gal", reiterada à maneira de estribilho, mas compreende

\footnotetext{
${ }^{38}$ Cf. Seção 5.2 .3 , p. 151 ss.
} 
também demais dêiticos de primeira pessoa ("me corresponder", "amo", "tenho [24 anos]", "nasci", "sonho", "acredito", "me dar") e, no limite, a imagem do sujeito-narrador em sua integralidade.

Meu nome é Gal

E desejo me corresponder

Com um rapaz que seja o tal

Meu nome é Gal

E não faz mal

Que ele não seja branco, não tenha cultura

De qualquer altura, eu amo igual

Meu nome é Gal

E tanto faz

Que ele tenha defeito

Ou traga no peito crença ou tradição

Meu nome é Gal, eu amo igual

Ah, meu nome é Gal

(declamado)

"Meu nome é Gal, tenho 24 anos

Nasci na Barra Avenida, Bahia

Todo dia eu sonho com alguém pra mim

Acredito em Deus, gosto de baile, cinema

Admiro Caetano, Gil, Roberto, Erasmo,

Macalé, Paulinho da Viola, Lanny

Rogério Sganzerla, Jorge Ben, Rogério Duprat,

Waly, Dircinho, Nando,

E o pessoal da pesada

E se um dia eu tiver alguém com bastante amor pra me dar

Não precisa sobrenome

Pois é o amor que faz o homem." 
Tal entrelaçamento enunciativo só se faz graças a uma seleção de timbres particular. Aqui, a permuta timbrística comprometeria por completo a eficiência persuasória do texto. Caso o fazer-interpretativo do ouvinte-enunciatário não reconheça Gal Costa iconizada no revestimento timbrístico desse verso (e da canção, por extensão), a debreagem enunciativa ficaria em suspenso e apenas uma inferência pragmática levaria o ouvinte a decidir o impasse e, enfim, aceitar aquilo que o enunciado lhe propõe.

Um revestimento timbrístico incontestemente associado a qualquer figura diferente de Gal aniquilaria qualquer possibilidade de debreagem enunciativa bem-sucedida. A permuta por qualquer voz masculina torna patente essa incompatibilidade. Isso mostra como a configuração do substrato linguístico dessa canção reclama para si um revestimento timbrístico específico, ao contrário do que predizem as assunções correntes sobre a "livre projeção sobre o enunciado".

"Fico assim sem você" (Claudinho e Bochecha) Tal imbricamento íntimo entre letra e timbre cria um efeito de autenticidade elocutiva não ignorado pela indústria fonográfica em sua incessante busca pelo próximo sucesso comercial. É o que acontece com a canção pop "Fico assim sem você", gravada em 2002 pela dupla carioca Claudinho e Bochecha. Antes de desembocar na aberta declaração de amor do refrão, a letra vai desdobrando paradigmaticamente uma série de pares incompletos como forma de mostrar o sentimento de falta causado pela ausência da pessoa amada.

Avião sem asa,

fogueira sem brasa,

sou eu assim sem você.

Futebol sem bola,

Piu-piu sem Frajola,

sou eu assim sem você.

Por que é que tem que ser assim

se o meu desejo não tem fim.

Eu te quero a todo instante

nem mil alto falantes

vão poder falar por mim.

Amor sem beijinho,

Bochecha sem Claudinho,

sou eu assim sem você. 
Circo sem palhaço,

namoro sem amasso,

sou eu assim sem você

Tô louco pra te ver chegar,

Tô louco pra te ter nas mãos.

Deitar no teu abraço,

Retomar o pedaço

que falta no meu coração.

[refrão]

Eu não existo longe de você

e a solidão é o meu pior castigo.

Eu conto as horas pra poder te ver

mas o relógio tá de mal comigo

Neném sem chupeta,

Romeu sem Julieta,

sou eu assim sem você.

Carro sem estrada,

queijo sem goiabada,

sou eu assim sem você

Por que é que tem que ser assim

se o meu desejo não tem fim.

Eu te quero a todo instante

nem mil alto-falantes vão poder

falar por mim

[refrão]

O par incompleto apresentado no décimo terceiro verso ("Bochecha sem Claudinho") é apenas mais um dos muitos apresentados ao longo da canção exceto por um detalhe decisivo: esse verso vem entoado pelo timbre do próprio cantor Bochecha, que refere-se a si mesmo por meio de uma expressão nominal. Dessa sobreposição entre revestimento timbrístico e substrato linguístico ("Bochecha") resulta uma embreagem de 
pessoa pois, iconizado em seu timbre, o sujeito-narrador alude a si próprio usando uma forma de terceira pessoa. A isso acrescenta-se ainda a alternância timbrística dos versos entre um e outro integrante da dupla na criação de um diálogo entre sujeitos do enunciado. Tal efeito cênico é reforçado por certa ambiguidade dêitica instalada no verso-mote ("Sou eu assim sem você"), que pode ser interpretado tanto como o sujeito-interlocutário no plano do enunciado ("Claudinho") como o sujeito-narratário, no caso, o ouvinte da canção.

Tal astúcia enunciativa só pode ter êxito graças a uma combinatória peculiar entre timbre e letra. Analisando apenas sua configuração verbal, nada distinguiria esse verso dos demais pares apresentados, constituídos todos eles por sintagmas nominais e, portanto, desencadeadores de debreagem enunciva de pessoa. O que singulariza o verso em tela é sua possibilidade de contrair embreagem enunciativa de pessoa mediante revestimento timbrístico específico.

Exceto em um improvável mundo imaginário em que objetos inanimados fossem dotados de voz e articulações fônicas aptas ao canto, isso jamais acontecerá com versos como "Futebol sem bola" ou "Fogueira sem brasa", por exemplo. Deles, pode-se dizer que são "imunes" à permuta timbrística pois continuam se comportando como debreagens enuncivas de pessoa. Em contrapartida, o verso "Bochecha sem Claudinho" se mostra sensível ao revestimento timbrístico selecionado, pois dele depende o efeito de embreagem de pessoa aqui constatado. É o que de fato acontece na regravação dessa canção por Adriana Calcanhoto (2004). ${ }^{39}$ Tendo o ouvinte atribuído o timbre da intérprete e os antropônimos ${ }^{40}$ do verso em questão a sujeitos distintos, o verso "Bochecha sem Claudinho" passará então a uma debreagem enunciva de pessoa, idêntica a todas as demais. Aqui, fica mais uma vez evidente o papel decisivo desempenhado pelo fazer-interpretativo e pelo contrato de veridicção no controle dos mecanismos de breagem.

Demonstra-se, assim, como uma operação enunciativa investigada até então exclusivamente em sua dimensão verbal pode ser corroborada ou refutada pela debreagem sensível efetuada pelo timbre. A sobreposição de debreadores enunciativos na camada timbrística e na verbal reforça duplamente o efeito de ancoragem ao sujeito-narrador. Em contrapartida, uma eventual incongruência entre esses dois componentes exigirá que o sujeito-enunciatário recalcule seu fazer-interpretativo.

"Garota do Roberto" (Waldirene) O exame desse objeto revelou outro efeito relevante da seleção timbrística além das breagens, a saber, o redelineamento da imagem do sujeito-narrador. Esse efeito de sentido se mostra igualmente produtivo na linguagem da canção. É o que demonstra, por exemplo, a composição "A garota do Roberto", gravada

\footnotetext{
${ }^{39}$ Disponível on-line por hiperlink da internet.

${ }^{40}$ Assim como observado em "Meu nome é Gal" (cf. p. 168) e na declaração de Maluf (cf. p. 158), a sobreposição do timbre com um antropônimo verificada aqui não é fortuita. Cf. Cap. 2.6, p. 64.
} 
pela intérprete Waldirene em 1967. Dando por conhecidos o contexto histórico e cultural da Jovem Guarda ${ }^{41}$ e a alusão ao artista Roberto Carlos no título, interessa-nos aqui sobretudo o íntimo enlace da letra com seu revestimento timbrístico, o que se verifica pela debreagem enunciativa de pessoa efetuada pelos termos destacados em itálico abaixo:

Sou a garota papo firme que o Roberto falou

Dirijo em disparada pois eu sou um amor

Sou a garota que eles pensam que vão conquistar

Pois ja pensei e nem bola vou dar

Sou a garota papo firme que o Roberto falou

Estou por aí dentro da onda

Aqui esta turma de cabeludo

Que só pensa em cantar não pensa em se casar

Se tenho mil razões por ser assim

A minissaia fica bem em mim

Eu vou deixar a turma toda louca

A turma toda com água na boca

Sou a garota papo firme que o Roberto falou

Por isso sou um amor

No presente estágio de amadurecimento da semiótica da canção, nenhuma dúvida resta sobre o efeito de naturalidade da interlocução coloquial visado por esses elementos (cf. Tatit, 1986, 1997, 2002). Aqui, cabe-nos enfatizar que tal efeito de sentido depende também de um revestimento timbrístico apropriado. A debreagem enunciativa ativada na letra funciona com naturalidade quase imperceptível quando o timbre que a reveste também remete a um sujeito passível de encarnar o papel de "garota do Roberto". Conhecendo as personalidades desse cenário musical, ouvintes daquela época atestavam, com satisfação, a fidedignidade da letra da canção com seu mundo circundante, como se os personagens de dentro da canção e os do "mundo real" se mesclassem.

Em contrapartida, ouvintes mais jovens desconhecedores do timbre dessa intérprete poderão apenas presumir a existência de uma figura feminina celebrizada como "a garota do Roberto". Diga-se de passagem que também a alusão a um certo "Roberto" - designado,

\footnotetext{
${ }^{41}$ Cf. Severiano (2009, p. 396-404); Pugialli (1999, p. 305).
} 
aliás, por um nada fortuito artigo definido - pode malograr por falta de referências intertextuais e interdiscursivas. Levando esse raciocínio ao limite, a permuta por um revestimento timbrístico abertamente incompatível - um grave masculino de Orlando Silva, por exemplo - provocaria reações de estranhamento e forçaria o enunciatário a rever os termos de seu contrato veridictório. Uma hipotética execução dessa letra ao timbre do próprio Roberto Carlos, aludido no segundo verso, comprometeria toda a credibilidade enunciativa da canção e seria tolerável apenas como paródia ou exercício lúdico.

"Já fui uma brasa" Ainda rondando esse período da canção brasileira, destaca-se o peculiar comportamento enunciativo do timbre na canção "Já fui uma brasa", composta e gravada por Adoniran Barbosa em 1968. Em um jogo de palavras com a gíria "brasa mora" em voga à época, o narrador-interlocutor da canção lamenta ter sido descartado em favor dos sucessos da Jovem Guarda e confidencia, não sem certa ambiguidade sexualizante, sua vitalidade adormecida. Para além da ancoragem à primeira pessoa (destacada em itálico na letra), vale destacar aqui as numerosas pistas da identidade desse sujeito, polvilhadas ao longo da canção em alusões intertextuais ao "violão" e à "saudosa maloca".

Eu também um dia fui uma brasa

E acendi muita lenha no fogão

E hoje o que é que eu sou?

Quem sabe de mim é meu violão

Mas lembro

Que o rádio que hoje toca

Iê-iê-iê o dia inteiro,

Tocava saudosa maloca

Eu gosto dos meninos deste tal de iê-iê-iê porque

Com eles canta a voz do povo

E eu que já fui uma brasa,

Se assoprarem, posso acender de novo

(declamado):

É negrão ... eu ia passando, o broto olhou pra mim e disse: "É uma cinza, mora?"

"Sim, mas, se assoprarem debaixo dessa cinza, tem muita lenha pra queimar ..." 
A letra constrói a imagem de um sujeito de idade já avançada ("cinza") e saudoso de outros tempos idos (versos 1-2, 5-6, 9). Tecendo uma rede de remissões intertextuais e interdiscursivas, o sujeito enunciatário poderá tirar suas conclusões e reconstituir, com a ajuda do revestimento timbrístico, a identidade do sujeito por trás dessa canção. Embora com laços menos fortes do que os casos anteriormente apresentados, o substrato linguístico dessa canção sugere um revestimento timbrístico preferencial (ainda que não obrigatório) iconizando Adoniran Barbosa.

Tal determinação do revestimento timbrístico será mais flexível ou mais intransigente a depender da ativação dessa rede intertextual e interdiscursiva. Em um suposto cenário de tabula rasa em que nem referências interdiscursivas e nem timbre são reconhecidos, resultarão inoperantes todas as coerções apontadas acima. ${ }^{42}$ Essas constatações levantam evidências de como também os temas e as figuras do substrato linguístico parecem encaminhar revestimentos timbrísticos preferenciais.

"Eu dei" (Carmem Miranda) Outro caso ilustrativo desse fato é a canção "Eu dei" (2013 [1937]), que se vale da ambiguidade do verbo "dar" e suas acepções sexuais em português brasileiro para criar um tom de malícia jocosa. Entoado pelo timbre de Carmem Miranda, o mote "eu dei" entremeia toda a canção em torno da questão reincidente e, não por mero acaso, entoada por timbres masculinos: "O que foi que você deu, meu bem?". Entre esses dois interlocutores, desenreda-se aqui um joguete provocativo de adivinhação cujas meias-palavras bastam para bom entendedor.

- Eu dei,

O que foi que você deu, meu bem?

- Eu dei,

Guarde um pouco para mim também,

Não sei, se você fala por falar sem meditar,

- Eu dei,

Diga logo, diga logo, é demais,

- Não digo, e adivinhe se é capaz,

Você deu seu coração,

- Não dei, não dei,

Sem nenhuma condição,

- Não dei, não dei,

O meu coração não tem dono,

\footnotetext{
${ }^{42}$ Cf. Subseção 5.4.4, p. 193 ss.
} 
Vive sozinho, coitadinho, no abandono.

[repete parte 1]

Foi um terno e longo beijo,

- Se foi, se foi,

Desses beijos que eu desejo,

- Pois foi, pois foi,

Guarde para mim unzinho,

Que mais tarde pagarei com jurinhos.

[repete parte 1]

Mais do que se comprazer com os gracejos da letra, interessa aqui sobretudo mostrar como o pretendido efeito de humor não é indiferente à seleção de revestimento timbrístico. Se, por uma hipotética permuta, todas as ocorrências do mote "eu dei" fossem entoadas por um timbre masculino e os demais versos fossem entoados por timbres femininos, esse crivo de leitura sexualizante ficaria fatalmente comprometido.

O humor derivado da insinuação sensual desse verso também depende da debreagem enunciativa, ativada na camada verbal pelas formas de primeira pessoa (assinaladas em itálico) e, na camada musical, pelo timbre. Esse entrelaçamento entre letra e timbre viria a se fragilizar caso fossem apagadas todas as ancoragens ao eixo eu-tu do diálogo encenado. Além da interação entre substrato linguístico e revestimento timbrístico, tal efeito de sentido depende também do quadro de crenças do ouvinte-enunciatário; no caso em tela, acerca da imagem construída desse sujeito-narrador e também de sua (não-)conformidade com os papéis de gênero normatizados na sociedade.

"A voz do morro" (Zé Keti) A exemplo do que acontece com o gênero na canção "Eu dei", essa cristalização da identidade do sujeito "dono da voz" em seu timbre pode incidir também em toda sorte de marcadores sociais (proveniência geográfica, classe social, pertencimento a subgrupos etc.), reconhecíveis discursivamente em seus papéis temáticos e patêmicos. Gravada na voz de Zé Keti, a canção "A voz do morro" ilustra como semelhante processo se aplica à identidade regional e social. Assim como os demais exemplos apresentados até aqui, a naturalidade da interlocução decorre do uso dos marcadores enunciativos de primeira pessoa. Aqui, a ancoragem espacial se coaduna com a debreagem enunciativa de pessoa e alicerça o efeito de diálogo encenado no aqui-e-agora 
da enunciação.

Eu sou o samba

A voz do morro sou eu mesmo, sim senhor

Quero mostrar ao mundo que tenho valor

Eu sou o rei dos terreiros

Eu sou o samba

Sou natural daqui do Rio de Janeiro

Sou eu quem levo a alegria

Para milhões de corações brasileiros

Mais um samba, queremos samba

Quem está pedindo é a voz do povo de um país

Pelo samba, vamos cantando

É ...pra melodia de um Brasil feliz

A letra da canção tece ao longo de seus versos uma personificação do samba, incorporada por um sujeito boêmio ("eu quem levo a alegria"), carioca ("natural daqui do Rio de Janeiro") e bem estabelecido em seus círculos sociais ("a voz do morro", "rei dos terreiros"). Como é típico das canções tematizantes (Tatit, 1997, 2002), "A voz do morro" constrói em torno de sua figura principal uma atmosfera euforizante de celebração das conjunções com a identidade regional, coletiva ("milhões de corações brasileiros", "a voz do povo de um país") e cultural ("Mais um samba, queremos samba").

Ao lado das reiteradas formas dêiticas de primeira pessoa, as demais expressões nominais também co-operam para atribuir ao sujeito da enunciação uma postura passional e uma ancoragem espacial específica. Configurado dessa forma, o substrato linguístico dessa canção é menos restritivo quanto ao espectro de possíveis revestimentos timbrísticos. Embora essa margem seja ampla, requere-se ainda um grau mínimo de compatibilização com o perfil de sujeito-narrador para não comprometer a credibilidade da imagem desse sujeito e, por tabela, da canção como um todo.

Reagiria com estranheza o ouvinte que, inesperadamente, reconhecesse por trás da letra o timbre de um sujeito pouco alinhado a essas balizas temáticas, figurativas, passionais e narrativas. Embora não impossível, seria ao menos inusitado constatar, encarnando o substrato linguístico dessa canção, o timbre de um rapper (Emicida, Crioulo, Rincón Sapiência, etc.), de um cantor caipira (Pena Branca e Xavantinho, Almir Sater, etc.) ou mesmo de forró (Luiz Gonzaga, Dominguinhos, etc.) - dando por conhecida pelo ouvinte sua atinência a contextos socioculturais divergentes daqueles instaurados 
pela letra. Semelhante caso de compatibilização parcial entre timbre e papéis temáticos e patêmicos construídos pelo substrato linguístico se dá a ver também em "Olhos coloridos", imortalizada no timbre de Sandra de Sá. Ao lado da debreagem enunciativa de pessoa, encontram-se aqui perfilados diversos marcadores figurativos, temáticos e passionais que delineiam a identidade negra empoderada do sujeito-narrador protagonista dessa canção.

Os meus olhos coloridos

Me fazem refletir

Eu estou sempre na minha

E não posso mais fugir

Meu cabelo enrolado

Todos querem imitar

Eles estão baratinados

Também querem enrolar

Você ri da minha roupa

Você ri do meu cabelo

Você ri da minha pele

Você ri do meu sorriso

A verdade é que você

(Todo brasileiro tem!)

Tem sangue crioulo

Tem cabelo duro

Sarará crioulo

Aqui, não se trata mais de julgar revestimentos timbrísticos obrigatórios ou proibidos, mas sim de certo ajuste apenas parcial entre o que a letra apresenta e os semantismos temático-figurativos infundidos previamente no timbre. Qualquer julgamento dessa natureza é impossível sem certo grau mínimo de densidade figurativa. Um timbre identificado de maneira apenas genérica por marcadores como "masculino", "feminino" ou "passionalizante" não teria suficiente densidade figurativa para contrair relações nem de compatibilidade, nem de incompatibilidade com a letra. Numa tal circunstância, seria impossível ir além da indefinição.

A esse respeito, suponhamos um cenário hipotético em que o substrato linguístico de "Diário de um detento" (Racionais MCs) seja revestido pelo timbre de João Gilberto. 
Essa combinação provocaria a recusa por parte dos ouvintes habituados ao caráter sentimentalista e por vezes algo infantilizante das letras tão frequentemente materializadas nesse timbre (Tatit 2004b , p. 80; Tatit 2014, p. 390). Sublinhemos que essa reação (de estranhamento ou naturalidade) dependerá imperiosamente da prototipia timbrística e, por tabela, da identificação do respectivo sujeito como fonte-sonora. ${ }^{43}$

Mais do que mero exercício de fantasia descompromissada, essa associação inusitada entre timbre e tecido temático-patêmico da letra foi o epicentro de um curioso episódio da música popular brasileira. Às vésperas da etapa final do Festival da Música Popular Brasileira, promovido pela TV Record em 1966, Geraldo Vandré resistia em aceitar que sua composição "Disparada" fosse interpretada por Jair Rodrigues, por receio de que seu timbre já imbuído de certa imagem de despojamento e irreverência viesse a prejudicar o forte engajamento social e político cunhado no substrato linguístico dessa canção (Ribeiro, 2002 , p. 89).

Porque representa um caso limítrofe, essa ancoragem ao sujeito da enunciação pela semântica discursiva é mais lábil e menos categórica do que aquelas efetuadas pela debreagem duplamente desencadeada por timbre e marcadores enunciativos de pessoa. A despeito de sua maior dependência a dados contextuais, esse fenômeno mostra as facetas mais nuançadas e sutis desse processo de reificação timbrística, para além de seus exemplos mais flagrantemente prototípicos.

Em nossa experiência estética de ouvintes, delimitamos um horizonte de expectativas sobre quais temas e quais universos figurativos são mais propensos a se manifestar no timbre de determinado intérprete. Essa expectativa se constrói pela depreensão de recorrências estáveis em uma dada totalidade, à maneira do que ocorre no estilo discursivo: "estilo é um efeito de individuação dado por uma totalidade de discursos enunciados" (Discini, 2004 , p. 27). Da mesma forma se dá a prototipização do timbre. Em grande medida, esse processo varia em função da inserção interdiscursiva e intertextual do sujeito-enunciatário.

Ao fim e ao cabo, toda essa caracterização nada mais é do que aquilo que Tatit (2002) alcunha de "dicção do cancionista" em sua mais ampla acepção. Trata-se, no fundo, da ideia de que cancionistas consagram sua "persona cancional" privilegiando determinadas configurações semânticas e rítmicos-melódicas em detrimento de outras. ${ }^{44}$ Comentando sobre a ascensão dos cancionistas na década de 1930, esse autor aponta o papel do timbre (referido aqui pelo termo "voz") na consubstanciação dessa imagem do sujeito (i.e., seu "modo de ser").

Bem mais poderosa que os tradicionais recursos enunciativos

\footnotetext{
${ }^{43}$ Cf. Cap. 2.

${ }^{44}$ Semelhante efeito de impregnação em uma personalidade integral já havia sido notado em Tatit (2014, p. 317) acerca de Itamar Assumpção.
} 
de ancoragem na primeira pessoa, no 'eu lírico', a entoação atrela a letra ao próprio corpo físico do intérprete por intermédio da voz. Ela acusa a presença de um 'eu' pleno (sensível e cognitivo) conduzindo o conteúdo dos versos e inflete seus sentimentos como se pudesse traduzi-los em matéria sonora. De posse dessa força entoativa, [...], os cancionistas se esmeraram em fazer dos intérpretes personagens definidos pela própria entoação. Ouvia-se então a voz do malandro, a voz do romântico, a voz do traído, a voz do embevecido, a vOZ do folião, todas revelando a intimidade, as conquistas ou o modo de ser do enunciador. (Tatit, 2004b, p. 75-76, grifos nossos)

Note-se como, nessa passagem, o autor sintetiza com concisão lapidar a ideia de sobreposição de debreagens (verbal e timbrística) que viemos persistentemente desdobrando aqui. Na passagem que se segue à citação, Tatit (2004b, p. 77-78) prossegue comentando como certo descompasso entre timbre e letra conferia ao cancionista uma imagem inverossímil que, ao final de contas, levou ao fracasso o projeto varguista de inocular na canção brasileira um teor moralizante mais alinhado à ideologia do Estado Novo. ${ }^{45}$ Guardadas as devidas proporções, trata-se do mesmo fenômeno que procuramos demonstrar a exemplo de "Olhos Coloridos", "Eu dei", "Já fui uma brasa" e "A voz do morro". É a imagem do sujeito-narrador e a força de sua assunção do enunciado que está em jogo aqui. Tais exemplos mostram que, apesar de mais evidentemente reconhecível em alguns casos particulares, esse "efeito bumerangue da voz" (Tatit, 2016, p. 136) é de fato um fenômeno sistêmico. Para garantir sua credibilidade enunciativa, não basta à canção entremear seus elos de letra e melodia; é preciso também forjá-los em material timbrístico adequado.

\section{Melodia}

Além das coerções impostas pela letra, também tessitura e registro impõem seu filtro de (in)compatibilização entre revestimento timbrístico e o componente propriamente musical do substrato cancional. Comparando sua própria extensão vocal com a tessitura da canção, intérpretes podem tomar a decisão de excluí-la ou incluí-la em seu repertório, efetuando para tal as eventuais adaptações necessárias. Entram também em jogo aí outros detalhes técnicos relacionados à gestualidade vocal exigida pela própria composição (cf. Machado, 2012). Particularmente ilustrativa é a consabida predileção de uma cantora como Carmem Miranda por melodias aceleradas e entrecortada de ataques consonantais. Em terreno estético sensivelmente distinto, corrobora também essa constatação o fato de

\footnotetext{
${ }^{45}$ Sobre essa empreitada de "purificação" do samba, cf. Severiano (2009 ,p. 265-270).
} 
que as classificações vocais cunhadas pelas escolas de canto erudito dizem respeito não apenas a tessitura e registro, mas também a certa "postura gestual" da voz.

No domínio da música popular de consumo, um caso especialmente insólito é a sonoridade "suja" e carregada de trejeitos vocais rítmicos que, à maneira de seus movimentos corporais na dança, permitiram a Michael Jackson criar uma personalidade vocal peculiar e inconfundível (Stegner-Petitjean, 2011). Mais do que idiossincrasia do astro pop, tais impurezas vocais sustentam certa atitude transgressora e antiestetizante de gêneros como o rock, o heavy metal, o funk carioca e o rap, todos eles abertamente avessos ao refinamento sonoro e timbrístico tão caro à música erudita.

No polo oposto, encontram-se aqueles que, por um obstinado trabalho técnico, visam aperfeiçoar sua flexibilidade vocal, sua impostação, sua precisão rítmica e seu registro. Entre esses dois pontos extremos, estende-se o vastíssimo território da voz humana, no qual florescem as mais diversas fisionomias timbrísticas. Essas, por sua vez, advêm da interação entre o revestimento timbrístico e o substrato melódico, constituído pela combinação de alturas, durações e intensidades. Embora não propriamente impossível, a consubstanciação de absolutamente todas as possibilidades rítmico-melódicas por um único timbre é, na prática, pouco provável. Pelo contrário, boa parte do trabalho de desenvolvimento vocal consiste justamente em orientar o intérprete a se concentrar na exploração dos potenciais expressivos de seu timbre e construir, assim, sua identidade vocal. ${ }^{46}$

Uma vez conquistada, essa autonomia estética permitirá ao sujeito elaborar seu repertório considerando a configuração rítmico-melódica das canções prospectadas. Decisões dessa natureza não se impõem apenas para intérpretes iniciantes, para os quais a flexibilidade técnica ainda em desenvolvimento põe empecilho, mas também para os mais experientes, cujo senso estético os impede de emprestar sua voz indiscriminadamente a qualquer composição. Como se fosse um percurso espontâneo, as inclinações estéticas do artista acabam inevitavelmente por encaminhar suas escolhas em direção a canções de perfil mais passionalizante, mais tematizante ou mais figurativizante.

Com o passar do tempo e a consagração pública, a precisão técnica de um intérprete em melodias de tessitura ampla e grandes saltos intervalares poderá ungir seu timbre com certo perfil passionalizante. Consolidado nesse papel, esse apenas dificilmente voltará a se tolher à estreita tessitura de canções de perfil tematizante e/ou figurativizante, à semelhança do que ocorre com as melodias simples ao piano. ${ }^{47}$ A correlação estável de um timbre a um determinado perfil cancional (passionalizante, tematizante ou figurativizante) não se efetua sem trazer consigo a reboque sua contraparte na dimensão verbal. Ou seja,

\footnotetext{
${ }^{46}$ Semelhante processo se dá também em contexto dramatúrgico na formação vocal de atores; cf. Quinteiro (1989,p. 72 ss.).

${ }^{47}$ Cf. p. 188 adiante.
} 
no caso em tela, nosso hipotético intérprete acabará por herdar também letras imbuídas de semantismos de certa natureza, mais pendentes à disforia da disjunção, conforme previsto pela tipologia tripartite de Tatit (1997).

De igual maneira, a impregnação de um timbre com um perfil melódico associado à tematização acarretará também a impregnação dos correspondentes semantismos, tendencialmente euforizantes e de celebração das conjunções. Encerra essa linha de raciocínio a conclusão de que certos timbres assumem certa personalidade figurativizante, enraizandose profundamente na força entoativa da canção (Tatit, 2016). Já bem acomodados à ilocução coloquial, o timbre de intérpretes com tal perfil se esquiva ao menor sinal de enrijecimento da estrutura musical e apenas excepcionalmente será encontrado soerguendo arroubos passionais em grandes arcos melódicos de andamento desacelerado ou obedecendo à risca a métrica imperiosa das canções tematizantes. Seu exemplo mais bem acabado é a dicção dos rappers (Segreto, 2019 , p. 47-128).

Exercendo sua vocação desmistificante, a semiótica vem empregar seu ferramental analítico para mostrar como tais personalidades vocais impregnadas em nosso imaginário musical derivam de um ajuste fino entre, de um lado, o binômio letra-melodia e, de outro lado, o timbre do "dono da voz". É apenas para fins de clareza expositiva que esses critérios são apresentados aqui por sua maior pertinência ora ao componente verbal $(\text { letra })^{48}$, ora ao componente musical (melodia da linha do canto) ${ }^{49}$, pois, na prática, essas duas instâncias jamais operam isoladas. Por sua natureza sincrética, a canção só consegue compatibilizar revestimento timbrístico e substrato linguístico-melódico contornando essas duplas coerções. Dando por encerrada a investigação das primeiras, resta ainda observar mais detidamente as segundas.

\subsubsection{Música}

No caso da música propriamente dita, a compatibilização entre revestimento timbrístico e seu substrato linguístico-melódico se manifesta naquilo que se designa usualmente por "linguagem do instrumento". São ditas idiomáticas para um instrumento as estruturas melódicas, rítmicas e harmônicas tidas por possíveis e/ou prováveis em seu timbre. ${ }^{50}$ Mais do que simples especulação semiótica, essa noção está presente no ofício prático de compositores e arranjadores: "Na medida em que os compositores preveem sonoridades determinadas para as suas obras, eles escrevem idiomaticamente, portanto de uma maneira típica para o instrumento, para a voz ou para tal orquestra." (Harnoncourt,

\footnotetext{
${ }^{48}$ Cf. p. 157 ss.

${ }^{49}$ cf. p. 182 ss.

${ }^{50} \mathrm{~A}$ partir de uma perspectiva estruturalista, tais combinatórias já foram esquadrinhadas em outros trabalhos em termos de relações de solidariedade (Hjelmslev, 2006 [1943]) entre timbre e os demais parâmetros sonoros de altura, duração e intensidade (cf. Shimoda, 2015).
} 
1982 , p. 107-108, grifos nossos, tradução nossa ${ }^{\text {lxxxv }}$ ). Essa passagem ilustra bem a ideia já pontuada anteriormente ${ }^{51}$ de que a instrumentação é de certa forma antecipada pelo projeto enunciativo sugerido pela escrita musical.

Quando, na fruição de uma peça musical qualquer, reconhecemos um determinado timbre instrumental, delineamos imediatamente um horizonte de expectativas acerca de seu devir rítmico e melódico. Tendemos a antecipar as direções tomadas pela melodia, bem como os padrões rítmicos de ocorrência mais previsível. Nesse exercício de antecipação e espera, construímos toda uma arquitetura de desdobramentos rítmico-melódicos prováveis, improváveis ou mesmo impossíveis. Para além dos detalhes anatômicos relacionados à construção do objeto instrumento em si, o que nos interessa aqui sobretudo é observar como a linguagem do instrumento encarna, na prática, uma restrição à seleção do revestimento timbrístico.

\section{Linguagem do instrumento}

Qualquer manual de instrumentação e orquestração apresenta testemunhos da linguagem do instrumento ao documentar informações básicas sobre registro, tessitura e amplitude dinâmica. ${ }^{52}$ A despeito de seu caráter generalizante, indicações dessa natureza constituem já as grandes linhas do que é julgado por uma certa doxa como (im)provável no timbre do instrumento descrito. Em suma, trata-se aqui de todas as restrições rítmicas e melódicas das quais nenhum instrumento está imune. Mesmo restringindo-se apenas ao universo da música ocidental, uma descrição em minúcia da linguagem de cada instrumento seria já um trabalho hercúleo - e talvez de proveito limitado para uma disciplina dedutiva por excelência, como é a semiótica. Cientes das limitações de tal exercício enciclopédico, propomos apresentar alguns casos emblemáticos que possam orientar o semioticista menos familiarizado com questões musicais.

Para início de discussão, tomemos como exemplo a guitarra e o violão. A despeito de suas semelhanças anatômicas, esses instrumentos desenvolveram linguagens próprias razoavelmente distintas entre si. Sumarizando suas particularidades em grandes linhas, Almada (2014 [2000] , p. 63) explica que a guitarra é um instrumento mais melódico, mais ágil e tende a trabalhar mais nas regiões agudas, ao passo que o violão funciona mais harmonicamente e se concentra na região grave. Ainda nesse trecho, para evitar certa redundância de funções e um consequente efeito de "embolamento" rítmico-harmônico, esse autor recomenda enfaticamente que arranjos de música popular contando com dois violões, duas guitarras ou com violão e guitarra façam distinção nítida de papéis, modelados

\footnotetext{
${ }^{51}$ Cf. seção 5.3, p. 155.

${ }^{52}$ Vale a pena ressaltar que a expressão "linguagem do instrumento" é empregada aqui em sua acepção mais geral, conforme empregada por musicistas. De um ponto de vista estritamente linguístico, seria mais adequado falar em "idioleto do instrumento", como argumentaremos ao longo da presente seção.
} 
conforme as características próprias destes últimos. Para fins de clareza expositiva, sumarizemos esses apontamentos (cf. Tabela 5.1).

\begin{tabular}{rll}
\hline & Instrumento 1 & InsTRUMENTo 2 \\
Altura & registro agudo & registro grave \\
Ritmo & levada mais solta & levada mais consistente \\
Harmonia & tensões harmônicas & acordes básicos \\
Função desempenhada & melodia & harmonia e ritmo \\
\hline
\end{tabular}

Tabela 5.1: Atribuição de papéis distintos a timbres assemelhados no arranjo. Fonte: elaboração própria a partir de Almada (2014 [2000] ,p. 63-71).

Longe de dogmatismos estéticos, as recomendações dadas pelo autor se pautam antes por certa cristalização das funções rítmicas, melódicas e harmônicas prototipicamente assumidas por esses timbres. Essas vão se sedimentando na memória discursiva e configuram pouco a pouco suas fisionomias timbrísticas particulares. A despeito da ampla margem de liberdade na atribuição desses papéis, ela ainda esbarra nas idiossincrasias de cada instrumento em particular. Evidências suplementares dessa cristalização discursiva são dadas pela seguinte nota a respeito da linguagem do violão: "Certos acordes, principalmente os construídos com um ou mais intervalos de segunda, são difíceis (dependendo do que vem antes e/ou depois), se não impossíveis de serem realizados." (Almada, 2014 [2000] ,p. 71). Esse é um caso modelar de incompatibilidade combinatória entre revestimento timbrístico e substrato musical. A restrição apontada só se aplica em função do timbre que o manifesta. É assim que acordes como o da figura 5.1 não se manifestam ao timbre do violão, ainda que pacificamente concebíveis em outros timbres, como o do piano.

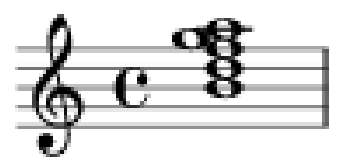

Figura 5.1: Acorde impossível na linguagem do violão. Fonte: elaboração própria com base em Almada (2014 [2000], p. 71).

Caso similar de cristalização de configurações do substrato musical (rítmico, melódico, harmônico etc.) no revestimento timbrístico se encontra também na descrição do piano: "Uma forma bem característica do idioma do piano é chamada de 'oitavas quebradas'. Funciona melhor legato em andamentos rápidos, e soa como uma espécie de tremolo. Tal efeito é muito usado nas sonatas de Beethoven." (Almada, 2014 [2000], p. 79, grifos nossos). Para além dos detalhes técnicos de execução, interessa sobretudo 
sublinhar como se assoma de maneira evidente a premissa de que tais estruturas formais (oitavas quebradas, no caso em tela) são tidas como prototípicas nesse timbre. Na mesma direção vão também as recomendações do autor para evitar saltos bruscos na progressão harmônica do acompanhamento pois chamam demasiada atenção para si, "além de não serem nada pianísticos" - para resgatar as palavras do autor (Almada, 2014 [2000], p. 81). O uso do adjetivo "pianístico" não deixa dúvidas quanto a essa intuição de que o timbre de piano se compatibiliza melhor com determinadas configurações melódico-harmônicas e rítmicas do que com outras.

É interessante notar como mesmo a consabida flexibilidade técnica do piano, insuperável mesmo entre seus pares de orquestra, tem também seus limites. Esses se mostram ainda mais proeminentes na família dos sopros e conferem a seus membros "personalidades" próprias bem distintas entre si. Assim, saltos intervalares de grande amplitude, arpejos, escalas e tremoli executados em andamento acelerado são triviais em um timbre de flauta, embora mais raros em outros instrumentos. Além disso, pode ser empregada com êxito em dobramentos e mostra melhor desempenho sonoro nas regiões aguda e superaguda. (Almada, 2014 [2000],p. 110-111). Um dos adornos estilísticos mais idiossincráticos da flauta é o frulato, concessivamente executável em outros timbres, como no trompete (2014 [2000] , p. 179), ou mesmo impossível em outros casos.

Ainda sem sair do terreno dos sopros, outro exemplo insólito é o saxofone. Almada (2014 [2000]) comenta que, a despeito das numerosas críticas a seu timbre supostamente impuro, a linguagem desse instrumento já incorporou certa sonoridade também "suja", bastante carregada de vibratos e herdada do estilo de execução consagrado por certas correntes do jazz. Nas palavras do autor: "Talvez essa sonoridade não possa mais ser dissociada do instrumento, o que faz com que tentativas nesse sentido soem artificiais e, por isso, insatisfatórias." (2014 [2000] , p. 123) Em uma observação como essa, salta aos olhos a notada resistência à descaracterização da sonoridade do instrumento. Tudo se passa como se as figurações rítmicas suingadas que se inocularam no timbre de saxofone se recusassem a abandoná-lo, sob o risco de transfigurar sua fisionomia sonora peculiar.

Rumando para as regiões mais graves, fagote e tuba fornecem também exemplos palpáveis do poder de sedimentação da linguagem do instrumento em seu timbre. Para esses, trinados e trêmolos são antes raros (ou mesmo impossíveis), embora abundantes (e mesmo triviais) em seus contraparentes de registro agudo. Além disso, articulações em stacatto são tidas como mais idiomáticas. Em timbre de fagote, legattos não são previstos senão em passagens curtas, ao contrário do que acontece no timbre de flauta e/ou clarinete, cuja escrita registra mais frequentemente passagens longas em legatto (cf. Almada 2014 [2000] , p. 230-233, 263-265).

Em visão panorâmica, os exemplos acima mencionados podem insinuar que tais 
cristalizações timbrísticas se limitam a ornamentos e a outros detalhes técnicos marginais. Essa falsa impressão precisa de imediato ser desconstruída. A compatibilização entre revestimento timbrístico e substrato musical penetra até as camadas mais profundas deste último, chegando a interferir na estruturação melódico-harmônica e rítmica. Antes mesmo do momento de execução, a escrita musical antecipa, projeta e sugere revestimentos timbrísticos ótimos ou preferenciais, em detrimento de outros desfavorecidos ou mesmo impossíveis, cujos exemplos abundam em manuais de arranjo e orquestração.

A esse respeito, os profícuos trabalhos de descrição da linguagem do violino são bastante eloquentes. Nesse instrumento, a execução de notas simultâneas é possível graças à técnica de corda dupla. No entanto, nem todas as combinatórias são manifestáveis.

Na figura 5.2, a pauta (a) apresenta intervalos factíveis em corda dupla, porém destaca com uma estrela simples $\left(^{*}\right)$ um caso inexequível. Em (b), todas as estruturas são tidas por possíveis e (c) destaca com estrelas duplas (**) uma passagem avaliada como possível, porém rara devido a sua difícil execução em registro agudo. É preciso enfatizar que tais restrições de escrita se aplicam unicamente em função de seu revestimento timbrístico. Os intervalos em questão só podem ser tratados como triviais, difíceis ou impossíveis quando considerados nos limites da linguagem do violino. Eventuais permutas timbrísticas (ao piano, por exemplo) tornariam observações como essas totalmente inócuas.

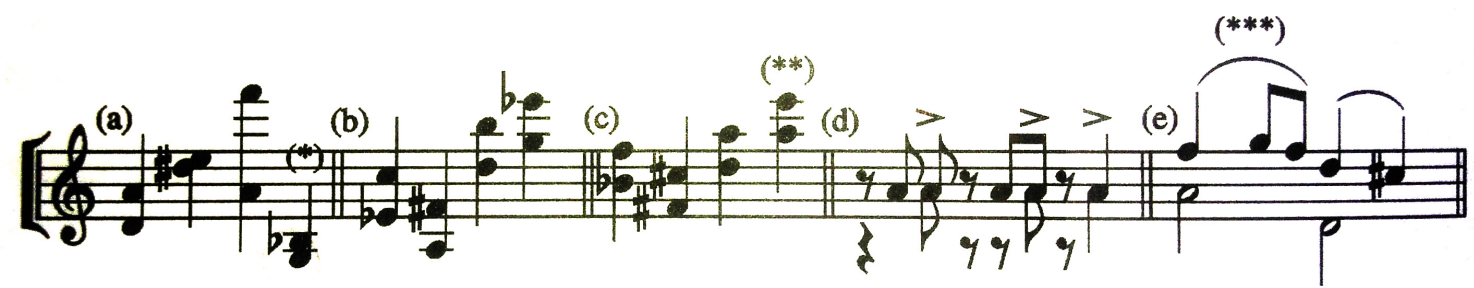

Figura 5.2: Cordas duplas ao violino. Fonte: Almada (2014 [2000],p. 298)

Um caso particularmente insólito de tais restrições idiomáticas se verifica nas recomendações sobre a escrita de portamentos. Efeito mais idiomático ao trombone, o portamento só lhe é possível dentro de um intervalo de $4^{\mathrm{a}}$ aumentada. Acima disso, ele se mostra impossível ao trombone (cf. Figura 5.3), ainda que perfeitamente realizável em instrumentos de corda friccionada, tais como violino e violoncelo.

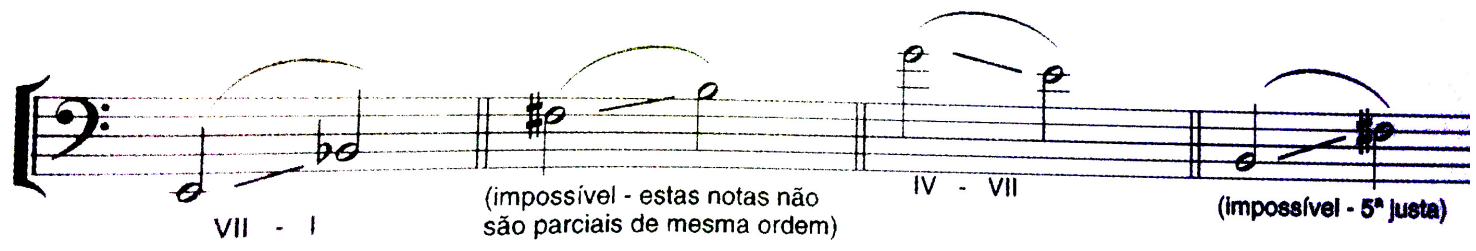

Figura 5.3: Portamento no trombone. Fonte: Almada (2014 [2000], p. 185) 
Mais uma vez, deve-se frisar que tal tipo de julgamento só se faz em função do revestimento timbrístico que o consubstancia. Colocando esse entre parênteses, todos os intervalos notados na figura acima seriam, no mais abstrato plano de conceptualização, igualmente admissíveis. É no momento de atribuição de material musical a seus respectivos timbres que são selecionadas, do espectro de realizáveis, quais combinatórias virão a ser efetivamente realizadas. Nisso consiste a arte do arranjo e da orquestração.

A compatibilização entre revestimento timbrístico e seu substrato musical tem tal força coercitiva que chega a afetar mesmo uma estrutura tão corriqueira quanto uma escala cromática. Sua execução em andamento prestissimo será menos frequente e idiomática em timbre de harpa, conforme documentado pelo clássico tratado de Rimsky-Korsakov (1922b [1873-1874]):

A harpa é essencialmente um instrumento diatônico já que todas as passagens cromáticas dependem da manipulação dos pedais. Por esse motivo, a harpa não se presta à modulação rápida, e o orquestrador fica advertido a ter em mente esse fato. (1922b [1873-1874], p. 28, tradução nossa lxxxvi)

Mesmo o aperfeiçoamento técnico de harpas cromáticas nos dias atuais não falseia esse dado, cujos efeitos se fossilizaram na escrita musical para esse instrumento ao menos até o início do século XX. Extrapolando o universo estético da música erudita orquestral, uma semelhante restrição às escalas cromáticas prestíssimas poderia bem ser vislumbrada em timbres como os de gaita de foles, ocarina entre outros. Em contrapartida, tal dificuldade jamais se coloca para os timbres de flauta transversal, piano ou mesmo de carrilhões. Disso conclui-se que melodias solistas em andamento acelerado serão mais favorecidas e mais facilmente encontráveis em certos matizes timbrísticos do que em outros. Essa inferência em nada difere da conclusão de que certos timbres são dotados de maior autonomia melódica ${ }^{53}$, ao passo que outros se prestam mais aos acompanhamentos harmônicos. ${ }^{54}$

Quando tomados em abstrato e sem qualquer indicação timbrística, os diversos exemplos apresentados até aqui poderiam ser tratados como equivalentes na medida em que obedecem às regras de estruturação musical (melódica e harmônica). Em termos de exequibilidade concreta, nada as distingue entre si. É preciso contudo sublinhar que, pela sua própria configuração, o substrato musical sugere indicialmente maior idiomaticidade em certos revestimentos timbrísticos preferíveis em detrimento de outros.

Reafirmemos com toda ênfase que não estamos trabalhando aqui no terreno das (im)possibilidades, mas sim das (im)probabilidades. Não se trata aqui de maneira alguma

\footnotetext{
${ }^{53}$ Cf. Cap. 4, p. 126 ss.

${ }^{54}$ Cf. Cap. 4, p. 110 ss.
} 
de proclamar estas ou aquelas estruturas musicais (rítmicas, melódicas e harmônicas) como obrigatórias ou proibidas para cada timbre particular. Ao invés disso, trata-se de delinear os parâmetros que distinguem, para um determinado revestimento timbrístico, os substratos musicais prováveis e esperados dos improváveis e inesperados. Em larga escala, tal horizonte de expectativas se cristaliza em nossa memória discursiva e cria uma fisionomia timbrística como se pudesse constituir um éthos da matéria sonora.

\section{Performances implicativas e concessivas}

A propósito, é a confirmação ou a ruptura dessa expectativa que nos leva a avaliar esteticamente a performance do instrumentista, julgando-a trivial por sua obediência à linguagem do instrumento ou excepcional por sua extrapolação. No primeiro cenário, substrato musical e revestimento timbrístico assumem uma conformidade pacífica. Tanto na acepção leiga quanto na acepção zilberberguiana do termo, o exercício musical corresponde precisamente à aquisição e à fiel reprodução dos padrões rítmico-melódicos previstos para determinado timbre. No segundo cenário, a incansável obstinação do sujeito pode levá-lo a superar, redimensionar e reatualizar as expectativas do que é considerado exequível no timbre em questão. Fazendo valer a concessividade, a performance do virtuose conquista seu estatuto de extraordinário estético quando extrapola esses limites.

Ao lado dos excessos do virtuosismo, também a falta provoca semelhante quebra de expectativas ao subaproveitar a ampla gama de possibilidades harmônicas e rítmicas previstas pela linguagem de um dado instrumento. Tal é o caso das melodias simples ao piano. Embora possíveis, elas tendem a não ser empregadas nesse instrumento senão para criar contraste formal com outras passagens de maior densidade (Almada, 2014 [2000], p. 79). Uma linha melódica avaliada como satisfatória e bem-formada para um timbre qualquer de sopros, por exemplo, poderia se revelar pouco idiomática e decepcionantemente atrofiada em um timbre de piano.

Tais avaliações subjetivas de falta e excesso (cf. Tatit, 2011) são apenas uma das possíveis manifestações de inconformidade entre substrato musical e revestimento timbrístico. Estas são flagráveis também nas substituições timbrísticas efetuadas pelas práticas de rearranjo. É nesse quadro que se pode entender a revitalização estética criada pela execução de melodias de choro ao timbre de viola caipira (Monte, 2016) ou ao violoncelo (Yo-yo Ma, 2003). Cumpre notar que, nesses casos, não se trata tanto da exploração deficitária ou desmensurada das limitações da linguagem do instrumento, mas sim de certa disparidade entre o revestimento timbrístico esperado e aquele de fato atestado em dada configuração rítmico-melódica. 


\section{Interpretações históricas de música antiga e barroca}

Essa discrepância se aplica também na avaliação da autenticidade das execuções de música antiga e barroca. A busca pela maior fidelidade possível envolve, em grande medida, o emprego da instrumentação original. É ponto pacífico que a 'atualização' timbrística pode incorrer em uma série de distorções e anacronismos que, no limite, descaracterizam por completo uma execução que se pretenda histórica. Não é outra a questão debatida em profundidade por Harnoncourt (1982) em Le discours musical: Pour une nouvelle conception de la musique. Avaliando criticamente as opções estéticas de grupos de música antiga e barroca, esse autor aponta a importância de respeitar com rigor a instrumentação para a qual as peças foram originalmente escritas:

Outro exemplo: si menor é uma tonalidade maravilhosamente fácil e brilhante na flauta transversal barroca, dó menor é uma tonalidade abafada e extremamente difícil. [...] Na flauta Böhm 'moderna', dó menor soa tão bem quanto si menor. [...] Em uma flauta Böhm, essas figuras falam com virtuosidade, como se elas fossem escritas na tonalidade mais fácil e mais clara; mais uma vez, aqui, $a$ ideia contida na instrumentação não pode ser assim realizada. (Harnoncourt, 1982 ,p. 120, grifos nossos, tradução nossal $\left.^{\text {lxxxvii }}\right)$

O excerto enfatiza o efeito de pasteurização causado pela execução de peças antigas com instrumentação dita 'moderna'. No caso em questão, o uso da flauta de Böhm acaba por uniformizar e nivelar em um mesmo patamar diferentes tonalidades que, na timbragem original da flauta barroca, assumiam cada qual uma fisionomia sonora sui generis; ora "maravilhosamente fácil e brilhante", ora "abafada e extremamente difícil". Não é preciso dar grandes mergulhos semióticos para reconhecer aí diferentes valorações estéticas. De um lado, o brilho e a eloquência de uma dicção rítmico-melódica desimpedida; de outro, uma sonoridade de baixa projeção, obstruída e pouco ágil. Essa diferença fundamental impede a livre transposição de tonalidades, que seriam tidas por equivalentes em uma flauta transversal moderna.

Respaldados pela argumentação de Harnoncourt (1982), insistimos enfaticamente aqui que a instrumentação não consiste em recobrir melodias e harmonias com timbres tomados à livre escolha. A permuta timbrística é também uma permuta veridictória. Essa combinação concessiva entre tonalidade e timbre confere interesse estético a certas composições barrocas que, quando executadas em instrumentação dita moderna, podem inadvertidamente passar a uma banalidade implicativa.

A exemplo dessas diferenças de sonoridade entre as flautas, tais observações se aplicam também, em maior ou menor grau, para toda transposição timbrística em geral. 
O caso da música antiga e barroca permite enxergar com mais nitidez um fenômeno onipresente em qualquer prática de reescrita musical, a saber, a compatibilização entre revestimento timbrístico e substrato musical, incluindo aí toda sua estruturação rítmica, melódica e harmônica.

\subsection{Discussão dos dados}

Chegando a esse ponto, é preciso fazer um balanço final para sintetizar os resultados de análise e poder interpretá-los criticamente. Nos momentos anteriores, a pesquisa tinha se concentrado sobre as relações contraídas pelos timbres entre si. ${ }^{55}$ Nessa etapa, as relações investigadas foram aquelas entre revestimento timbrístico e seu substrato linguístico-musical. Embora aventada de início como um expediente analítico apenas provisório, essa divisão revelou seu proveito ao permitir explicitar certas coerções combinatórias negligenciadas até então.

\subsubsection{Especificação do timbre e coerção combinatória}

Os dados revelaram que quanto maior a densidade figurativa do timbre, mais estreito o entrelaçamento entre essas instâncias. Em seu grau mais extremo, essa correlação culmina em efeitos de sentido de autenticidade, de veracidade e de plena assunção da palavra pelo sujeito. Tal é tipicamente o caso das canções figurativas segundo a tipologia de Tatit, 1997, nas quais o efeito de sentido de naturalidade coloquial se apoia sobremaneira na ilusão enunciativa e na colocação em cena do "dono da voz" (Tatit, 2016). Nesse cenário se encaixam também as embreagens de pessoa desencadeadas pelo timbre, especialmente aquelas decorrentes da sobreposição com um substrato linguístico particular, como revelado nos casos de "Maluf"56, "Gal"57, "Claudinho e Bochecha"58 e "(garota do) Roberto"59 analisados acima. Na extremidade oposta, o grau mínimo de restrição combinatória corresponderia à assunção inicial segundo a qual o timbre é livremente projetado sobre o enunciado sem qualquer determinação prévia. ${ }^{60}$ As diferentes compatibilizações entre revestimento timbrístico e substrato linguístico-melódico. relativizam - sem porém invalidar - a concepção de timbre como parâmetro sonoro contingencial e de livre projeção.

\footnotetext{
${ }^{55}$ Cf. Cap. 4.

${ }^{56}$ Cf. p. 158.

${ }^{57}$ Cf. p. 168.

${ }^{58}$ Cf. p. 170.

${ }^{59}$ Cf. p. 172 .

${ }^{60}$ Para re-enquadrar a questão usando a metalinguagem glossemática, seria possível considerar o primeiro cenário como uma função de determinação ou seleção (constante-variável) e o segundo cenário como uma função de constelação (variável-variável) (cf. Hjelmslev 2006 [1943],p. 39-45 ; Badir 2014,p. 154-159).
} 
Assim como a figuratividade não é "um simples ornamento das coisas" (Greimas, 2002, p. 78) nem um adorno gratuito do texto (Floch, 1985b , p. 79), também o timbre não pode ser reduzido a mero invólucro sonoro descartável a serviço da estrutura melódico-harmônica, rítmica e/ou linguística que lhe subjaz.

\subsubsection{Timbre vocal e instrumental}

Outra descoberta relevante revelada pelos dados sugere que a voz humana consegue comportar maior densidade figurativa do que o timbre de instrumentos musicais. Concluise isso da constatação de que a voz é capaz de iconizar entidades exclusivas que, interagindo com o substrato linguístico, desencadeia embreagens enuncivas de pessoa. Ao menos até o momento, semelhante efeito não foi verificado para os instrumentos musicais. Para esses, as relações de compatibilização entre revestimento timbrístico e seu respectivo substrato musical apontam para a iconização de famílias e classes, mas não para entidades exclusivas.

Para desencadear as operações enunciativas de debreagem e embreagem, o revestimento timbrístico deve portar investimento figurativo altamente denso. Esse, por sua vez, tende a singularizar o timbre dentre seus demais congêneres, acarretando naturalmente um processo de distinção e de separação. Assim sendo, pode-se inferir que os timbres vocais têm maior potencial à triagem do que suas contrapartes instrumentais. Para o senso comum, é mais plausível que um timbre exclusivo (p. ex., Chico Buarque) se destaque sozinho conduzindo a linha do canto. Menos previsível seria, no entanto, vislumbrar um coro de múltiplas vozes de "Chicos Buarques". Nunca é demais sublinhar que tal discussão não diz respeito a possibilidades e impossibilidades, mas sim a um horizonte de expectativas construído discursivamente pela práxis enunciativa. Esse efeito de surpresa do inusitado jamais se dá fora dos certames de um contrato de veridicção, firmado entre enunciatário e enunciador e vigente na comunidade de sentido que os circunscreve (Greimas, 2014 [1983], p. 115-145).

\subsubsection{Prototipia timbrística}

Conforme já pontuado em diversos momentos da presente investigação, as operações enunciativas ativadas pelo timbre dependem de seu reconhecimento por parte do enunciatário. Por sua vez, reconhecer um timbre significa, sobretudo, compará-lo a uma imagem-tipo desse objeto semiótico previamente construída pelo sujeito e recuperável em sua memória. ${ }^{61}$ Esse processo de prototipização do timbre não se dá puramente em função

\footnotetext{
${ }^{61}$ Cf. Cap. 2.
} 
de suas configurações acústicas per se, mas sim depende de sua colocação em discurso (mise en discours) e de seu modo de circulação em cada comunidade discursiva.

O tratamento teórico e metodológico aqui desenvolvido impossibilita a determinação a priori de um valor semiótico absoluto dos timbres - e é exatamente aí que repousa sua flexibilidade analítica. É por lidar com valores relativos e resultantes do cruzamento de valências que a abordagem tensiva consegue dar conta do comportamento semiótico aparentemente variável do timbre. Não se trata, portanto, de ousar impor significações definitivas aos mais diversos registros timbrísticos possíveis, mas sim de delinear as condições de sua emergência. Isso explica, por exemplo, por que os efeitos de sentido engendrados pelo timbre exigem que os sujeitos-enunciatários estejam inseridos em um dado contexto sociocultural e histórico. Apenas a título de clareza expositiva, retomemos como exemplo alguns objetos analisados anteriormente.

Um hipotético ouvinte estrangeiro e desconhecedor dos meandros da canção popular brasileira certamente permaneceria indiferente às embreagens desencadeadas pelas vozes de Adoniran Barbosa, Waldirene, Claudinho e Bochecha e Gal Costa. ${ }^{62}$ O mesmo se aplica também ao uso de vozes célebres nas dublagens, bem como na propaganda política. ${ }^{63}$ Tal impregnação semiótica explica também as dificuldades experimentadas pela etnomusicologia e pela organologia na tarefa de descrever a sonoridade de instrumentos musicais provenientes de outros contextos culturais e históricos. ${ }^{64}$

À medida que co-ocorrem sistematicamente, os arranjos formais do substrato linguístico (estruturas discursivas e narrativas) e musical (padrões rítmico-melódicos e harmônicos) vão progressivamente se cristalizando no timbre. Esse processo de prototipização só se efetiva pela recorrência e sedimentação no espaço discursivo coletivo constituído por uma dada comunidade de sentido. Por emergir na recorrência em totalidades discursivas, essa cristalização cultural do timbre é um fenômeno análogo à noção de éthos conforme apropriada pela semiótica francesa (cf. Discini, 2004). ${ }^{65}$

Tal percurso de construção de protótipos timbrísticos pertence mais à história do que à estrutura (Greimas, 1975b). Assim sendo, ele assume um caráter contingente, volátil e sujeito a variações contextuais. Em outros termos, cada sujeito constrói seu repositório particular de timbres prototípicos. Se, por um lado, essa ancoragem sociocultural e histórica abre margem para uma variabilidade individual ampla, por outro lado, ela explica o caráter persuasivo da seleção de revestimentos timbrísticos altamente iconizantes.

Os casos da dublagem e da locução analisados acima são particularmente eloquentes a esse respeito. Neles, os efeitos de sentido engendrados pelo timbre dependem

\footnotetext{
${ }^{62}$ Cf. p. 168 ss.

${ }^{63}$ Cf. p. 157 ss.

${ }^{64}$ Cf. p. 182 ss.

${ }^{65}$ Cf. p. 179 acima.
} 
sobremaneira de que enunciador e enunciatário partilhem certas referências intertextuais e interdiscursivas. Transbordando níveis de pertinência de análise, essa rede de remissões se enleia em torno um espaço-tempo socioculturalmente instituído, no qual se inscrevem os sujeitos da enunciação. Assim sendo, propomos sintetizar essas observações dizendo que os efeitos de sentido gerados pela identificação de timbres específicos tendem a arrefecer conforme o enunciatário se afasta desse epicentro sociocultural e histórico. Isso explica, por exemplo, por que sujeitos-ouvintes provenientes de outras culturas e/ou outros contextos históricos permanecem incólumes aos "acréscimos de sentido" proporcionados pela seleção de um revestimento timbrístico particular.

Sem conhecer previamente Gal Costa, a canção "Meu nome é Gal" perde boa parte do apelo que gozava junto ao público ouvinte à época de seu lançamento. A canção "Já fui uma brasa" também coloca de maneira patente essa ancoragem sociohistórica do timbre ao desenredar uma teia de remissões interdiscursivas ao movimento da Jovem Guarda, bem como às composições do próprio Adoniran Barbosa. Caso o leitor se permita um livre exercício de fantasia descompromissada, poderá vislumbrar que todos os efeitos de sentido deslindados aqui no presente trabalho poderão bem se tornar absolutamente inócuos em um hipotético futuro, no qual o público ouvinte de música popular não conte mais com Adoniran Barbosa nem Gal Costa em sua memória timbrística.

\subsubsection{Fenômenos análogos: typecasting}

Nesse momento, tomamos a licença da digressão para propor uma aproximação desse fenômeno com outro análogo, comumente conhecido pela sua designação em língua inglesa: typecasting. Se concedemo-nos a liberdade de tomar esse desvio, é por compreender que os custos impostos por ele são compensados pelos benefícios proporcionados. Para dizer em breves palavras, o typecasting é o efeito de estereotipia causado pela associação cristalizada de um ator (dramatúrgico e/ou cinematográfico) com os papéis por ele interpretados. O termo é definido pelo dicionário Merriam-Webster (s/d) da seguinte maneira: " 1 . escalar (um ator ou atriz) em um papel que exige as mesmas características do que aquelas possuídas pelo artista; 2 . escalar (um ator ou atriz) repetidamente para o mesmo tipo de papel; 3. estereotipar (acepção 2)". As definições coletadas de diversas fontes e reunidas no The Free Dictionary (s/d) vão na mesma direção:

1. Escalar (um ator) baseado em sua personalidade, histórico ou aparência física; 2. Escalar (um ator) em um papel ou papéis semelhantes àqueles que ele/ela interpretou no passado; 3. Fazer com que (um ator) seja escalado repetidamente em papéis similares; 4 . Perceber ou representar de maneira reducionista ou estereotipada. 
As eventuais dúvidas que ainda restam sobre isso podem ser, por fim, dissipadas em uma breve consulta ao Collins English Dictionary (s/d), que categoriza o verbete sob a rubrica "filme" e assim o define: "A prática de escalar um ator repetidamente no mesmo tipo de papel, especialmente por causa de sua aparência física ou sucesso anterior em papéis semelhantes". ${ }^{6}$ Eximindo-se do vão exercício da enumeração exaustiva, gostaríamos de extrair dessas definições duas características principais, nomeadamente (i) a compatibilização entre ator e personagem e (ii) a reiteração como catalisador da estereotipia. Abstraídas as particularidades da linguagem de manifestação dramatúrgica e/ou cênica, essas características nos permitem enxergar as reflexões sobre o timbre como um fenômeno de typecasting realocado no âmbito do sonoro.

O primeiro aspecto exibe nítidas semelhanças com a discussão, desdobrada a fundo aqui, sobre a compatibilização entre revestimento timbrístico e substrato linguístico-musical. Tanto em um quanto em outro domínio, trata-se de uma problemática assemelhada, a saber a interferência mútua entre níveis de análise distintos. De um ponto de vista semiótico, aquilo que se convenciona chamar de personagem é definido unicamente em função de suas relações com outros sujeitos e objetos do enunciado, incluindo aí toda sorte de desdobramentos narrativos e passionais (Greimas, 2014 [1983], p. 61-78). O mesmo se aplica também aos textos verbais orais, musicais e cancionais. O significado de uma sentença da língua falada independe, em princípio, da matéria fônica que o vocaliza, assim como uma composição instrumental apoia sua significação sobre sua macro-estrutura melódico-harmônica e rítmica.

Esse componente puramente formal não fica isento, no entanto, às diferentes manifestações substanciais que pode receber; como atores, para aqueles, ou como timbres, para estes. Guardadas as devidas proporções, o typecasting concerne também a relações de compatibilização ótima entre estratos. Tudo se passa como se determinadas configurações formais fossem, já em latência, mais favoráveis à manifestação em determinados arranjos substanciais do que em outros, conforme já pontuado aqui anteriormente ${ }^{67}$ É o que vimos ocorrer com mais proeminência na canção "Meu nome é Gal", mas também em "Garota do Roberto, "Fico assim sem você" e "Já fui uma brasa", ainda que com diferentes nuances. Esse efeito de identificação com o real engendrado pelo sincretismo entre sujeito do enunciado e sujeito da enunciação já havia sido notado em Tatit (2016) a respeito das cantoras da Era do Rádio. Guardadas as devidas proporções, esse fenômeno é também análogo ao que Fiorin (1999,p. 120 ss.) chama de macroembreagem.

Nele, o sincretismo entre sujeito da enunciação e sujeito do enunciado rompe com a ilusão referencial e, ao mesmo tempo, favorece a ilusão enunciativa subjacente ao efeito

\footnotetext{
${ }^{66}$ Para mais detalhes, cf. Tucker (2015,p. 91-102).

${ }^{67}$ Cf. Seção 1.2.2, p. 22 e Seção 5.3, p. 155.
} 
de identificação entre as vozes da narração e do narrado. ${ }^{68}$ No terreno da literatura, Fiorin (1999) reconhece nos narradores machadianos esse embaralhamento entre níveis: "Nos dois casos, ao mencionar outra obra do mesmo autor como sua, o narrador confunde os níveis do enunciador e do narrador, isto é, o narrador coloca-se como enunciador". (1999 ,p. 122). Transposto para a linguagem da canção, esse fenômeno descreve exatamente a embreagem desencadeada pela expressão "saudosa maloca" quando entoada pelo timbre de Adorniran Barbosa em "Já fui uma Brasa". Essa é uma evidência poderosa de que a atribuição de timbres ao núcleo de identidade da canção não é indiferente, mas pode sofrer coerções circunstanciais.

Voltemo-nos agora para a segunda principal característica recorrente nas definições de typecasting: a reiteração. Esse atributo cumpre papel fundamental na demarcação do caráter discursivo desse fenômeno. Não se trata aqui de uma discussão a respeito de traços exclusivamente morfológicos. Uma suposta conformidade perfeita entre ator e personagem (ou, comparativamente, entre timbre e componente verbal e/ou musical do enunciado) não é, por si só, condição suficiente para configurar a cristalização típica do fenômeno do typecasting. Ao contrário, ela demanda a reiteração. A prototipização deve se consolidar num tempo e num espaço e ser sancionada pela práxis enunciativa. Esse processo é por excelência discursivo e não pode ser explicado apenas por determinações de ordem articulatória, acústica e perceptual. Indo além, essa reiteração também não pode ser apreendida unicamente em termos quantitativos e numéricos. A esse respeito, é útil retomar Fontanille \& Zilberberg (2001) quando afirmam: "Sem o compartilhamento intencional que a intersubjetividade permite, a frequência de uso de uma forma não passa de pura repetição: a formação e o desaparecimento de uma norma se firmam nesse princípio" (2001, p. 181).

Aludindo explicitamente à noção de norma, as observações dos autores corroboram os achados revelados ao longo do presente trabalho. As relações de compatibilização entre timbre e substrato linguístico-musical são menos um atributo físico de uma presumível ontologia do som do que uma norma. Aqui, esse termo vem empregado em sua acepção mais genuinamente linguística e com todas as consequências que isso traz. Tanto na língua quanto no discurso, a norma é um contrato social vigente em comunidades delimitadas e, como tal, não emerge senão dentro de certo quadro de valores compactuados entre sujeitos. Vê-se aí que a identidade do timbre e todos os efeitos de sentido dela decorrentes não são dados naturais a priori, mas sim constructos da ordem do humano, como, aliás, todo fenômeno de sentido (Greimas, 1976 [1966], p. 11 ss.).

\footnotetext{
${ }^{68}$ Cf. Seção 5.2.4, p. 154.
} 


\section{Citações traduzidas no original}

lxxxiii "Mais la démarche de Benveniste impliquait, dans ses principes théoriques mêmes, qu'il dépasse le stade des «marques formelles de l'énonciation » et considère le discours comme un indice global de la subjectivité. Ces considérations sont importantes, dans la mesure où la mise au jour des marques formelles de l'énonciation représente, en fait, ce que l'on retient de la théorie de l'énonciation, jusqu'à la caricature. Il se passe ici ce qui s'est passé pour d'autres systèmes de pensée (et, au premier rang, la linguistique de Saussure) : la réduction d'une théorie à des données formelles, directement « utilisables »par des procédure heuristiques ou pédagogiques. Restreindre a théorie de l'énonciation de Benveniste aux seules analyse des indices ad hoc de la langue risque en effet d'occulter les perspectives ouvertes par ce qui constitue avant tout une théorie globale du langage." (Dessons, 1993, p. 44, grifos no original)

lxxxiv"Comme le débrayage cognitif, le débrayage sensible qui résulte de l'emission de la voix ou de la production du trait plastique suppose la projection d'un « non-je, non-ici, non-maintenant ». Car aussi bien la voix que le trait plastique impliquent un dédoublement du sujet, un détachement de lui-même : celui qui parle entend sa propre voix, et celui qui peint regarde son propre tracé ou sa propre touche." (Estay-Stange, 2011, p. 20).

lxxxv"Dans la mesure où les compositeurs prévoient pour leurs œuvres des sonorités déterminées, ils écrivent idiomatiquement, donc d'une manière typique pour l'instrument, pour la voix, pour tel orchestre." (Harnoncourt, 1982, p. 107-108)

lxxxvi“"The harp is essentially a diatonic instrument, since all chromatic passages depend on the manipulation of the pedals. For this reason the harp does not lend itself to rapid modulation, and the orchestrator is advised to bear this fact in mind." (Rimsky-Korsakov, 1922b [1873-1874], p. 28).

lxxxvii "Autre example : si mineur est une tonalité merveilleusement facile et brillante à la flûte traversière baroque, do mineur une tonalité sourde et extrêmement difficile. [...] Sur la flûte Böhm " moderne ", do mineur sonne aussi bien que si mineur. [...] Sur une flûte Böhm ces figures parlent avec virtuosité, comme si elles étaient écrites dans la tonalité la plus facile et la plus claire ; encore une fois, ici, l'idée contenue dans l'instrumentation ne peut être ainsi réalisée." (Harnoncourt, 1982 ,p. 120) 
Conclusão 


\section{Conclusão}

\subsection{Síntese geral e contribuições da pesquisa}

No presente estágio de avanço da investigação, é chegado o momento de prestar contas sobre seus principais pontos, suas contribuições, seus limites, bem como lançar sugestões de expansão para futuras pesquisas. O presente trabalho tomou a palavra cantada como ponto de partida, mas foi paulatinamente se afastando desse epicentro à medida que buscava avançar também nos territórios da fala pura e da música propriamente dita. Mesmo cedendo o protagonismo, foi a canção que desvelou o fio condutor de toda a reflexão desdobrada aqui. Assim sendo, esta não pode ser considerada uma pesquisa sobre canção, embora tenha se nutrido dela em larga medida. Ao invés disso, a investigação se afigura como um empreendimento eminentemente semiótico em face da natureza de seu objeto de estudo.

Esse se revelou, ao final de contas, menos atrelado ao timbre propriamente dito do que à significação por ele produzida. Mais do que proliferar novas tipologias de timbres, a presente pesquisa procurou, antes de tudo, flagrar seu comportamento enunciativo em sua colocação em discurso. Em um olhar retrospectivo, a prudência intelectual recomenda redimensionar o alcance das análises circunscrevendo-o apenas aos aspectos da significação de um objeto mais amplo, alcunhado pela designação "timbre".

Esse encaminhamento fica claro já no capítulo 1. Rejeitando desde o início o mero acúmulo enciclopédico de referências, o levantamento bibliográfico empreendido dialoga mais frontalmente com certo conjunto de pesquisas que enxerga o timbre como produtor de sentidos em detrimento de seus aspectos acústicos. Essa etapa logrou desfragmentar e consolidar os avanços conquistados por essas investigações, traçando assim as grandes linhas de força desdobradas a seguir pelos capítulos posteriores.

O capítulo 2 avançou a hipótese de que o timbre funciona como figura do mundo. Um percurso panorâmico desse conceito na semiótica greimasiana revelou como uma escala contínua de graus de densidade figurativa pode explicar a duplicidade encontrada nas descrições de timbre, referido ora por substantivos que nomeiam sua fonte sonora, ora por adjetivos qualificadores. Assim sendo, a individualidade do timbre pode variar em 
diferentes graus de uma escala, que vai do único e exclusivo ao genérico e irreconhecível. Tal achado permitiu concluir que a individuação de uma entidade única é apenas o caso mais extremo e idiossincrático de uma operação semiótica que se aplica a todo um espectro contínuo de diferentes graus de singularidade. No outro extremo dessa escala, encontra-se toda a massa indistinta de timbres não mapeados pelo sujeito-ouvinte.

A construção dessa escala de graus de especificidade constitui a coluna central sobre a qual se apoiam os grandes eixos de investigação do timbre. No grau mínimo de especificidade, encontram-se as descrições em termos de perfil temporal. No grau intermediário, encontram-se as descrições e categorizações de timbres em famílias, cuja compatibilidade mútua pode ser revelada pelos experimentos de triagens e misturas levados a cabo pela arte da orquestração. No grau máximo de especificidade, o timbre impõe coerções combinatórias com seu respectivo substrato linguístico-musical, o que impacta diretamente em seu comportamento enunciativo.

Os primeiros passos desse percurso foram pormenorizados ao longo do capítulo 3. Quando comporta um grau mínimo de densidade figurativa, o timbre vê arrefecer seu potencial de remissão à fonte sonora. Incapaz de pôr em cena uma entidade particular e específica, ele se deixa caracterizar nesse estágio apenas por descritores sinestésicos, que traduzem verbalmente sua constituição morfológica interna. Observada por lentes semióticas, essa silhueta temporal foi sistematizada por meio da conjugação de duas gradezas elementares, a saber fase aspectual e andamento, cada qual decomponível em uma oposição fundadora de base (ataque vs. extinção e acelerado vs. desacelerado). Uma tal reorganização permitiu categorizar os timbres em função de seu perfil temporal-aspectual com maior economia teórica e coerência interna. Além disso, evidências encontradas mostraram que a identidade de perfil temporal-aspectual é uma condição necessária, porém não-suficiente para que timbres sejam livremente permutáveis.

Até o momento, a análise resultou em categorias amplas e heterogêneas. Essa categorização pode ser refinada passando ao patamar intermediário de densidade figurativa. Nele, os timbres se deixam distribuir em classes e famílias organizadas em torno de um membro prototípico, conforme apurado no capítulo 4. A identidade e a coesão dessas famílias podem ser analisadas em termos de relações de (in)compatibilidade mútua. Essas foram, por sua vez, sistematizadas por meio das operações semióticas de triagem e de mistura, conforme documentadas subrepticiamente em tratados de orquestração e instrumentação.

Os resultados de análise apontaram que quanto mais semelhantes forem dois timbres, maior probabilidade de assimilação mútua. De maneira simétrica e inversa, quanto menos semelhantes forem dois timbres, menor sua propensão à mistura. Essa correlação entre o potencial de miscibilidade entre timbres e seu grau de semelhança mútua permite 
operacionalizar semioticamente a ideia de um "intervalo de timbres". Centrando foco sobre as relações intertimbrísticas, tal procedimento confere um tratamento sintaticizante de certo modo complementar à abordagem morfologizante praticada pela decomposição em fases temporais no capítulo anterior.

Os modos de agregar esses "ingredientes timbrísticos" não são ilimitados à livre escolha de cada indivíduo. Ao contrário, eles são regulados pelas normas estéticas vigentes em cada contexto sociocultural e histórico particular. As sonoridades instrumentais são fruto de um refinado balanceamento entre agregados e segregados timbrísticos, cujo equilíbrio é dominado por compositores e arranjadores após longos anos de dedicação e experiência prática.

Rentável na aplicação a timbres instrumentais, esse modo de proceder demonstra contudo seus limites para analisar timbres vocais em sua propriedade mais peculiar, a saber, a iconização de uma identidade única e exclusiva. Essa problemática é abordada avançando ao último patamar de densidade figurativa do timbre, conforme empreendido no capítulo 5. É principalmente a reflexão sobre a voz humana que joga luzes sobre a remissão do timbre a um sujeito particular, tanto em sua faceta linguística quanto estética. Essa ancoragem ao sujeito pode ser observada em termos objetivos pelas lentes conceituais da linguística, nomeadamente pelo aparelho formal da enunciação.

Para tal, foram examinadas as interações entre revestimento timbrístico e seu respectivo substrato linguístico-melódico. Tal abordagem permitiu pormenorizar sob quais condições o timbre se comporta de maneira análoga aos dêiticos das línguas naturais ("eu", "meu" etc.). Os resultados observados mostraram que as restrições combinatórias assumem a maior força coercitiva quando há um alto grau de densidade sêmica tanto no revestimento timbrístico (iconizando um sujeito exclusivo) quanto no substrato linguístico (notadamente no emprego de antropônimos). A rarefação da densidade sêmica em uma e outra instância torna sua compatibilização mais lábil.

O desenvolver da pesquisa revelou também que tais domínios de investigação não se configuram como recortes estáticos e casuais do timbre. Ao contrário, elas se articulam em interfaces, cada qual passível de aprofundamento em estudos futuros. A primeira interface coloca em interação o perfil temporal-aspectual do timbre e sua dinâmica de triagens e misturas. Nela, observou-se que a adição de timbres com ataque desacelerado faz o conjunto sonoro ser percebido semioticamente como mais "suave". Na direção inversa, a aglutinação de timbres com ataque acelerado torna o conjunto mais "áspero". 69

Essa interferência demonstra de maneira explícita como ocorre, no caso do timbre, o imbricamento mútuo e indissociável entre morfologia e sintaxe preconizado por Hjelmslev (2006 [1943], p. 30) e retomado em Zilberberg (2012,p. 61, 66, 75). É essa dependência

\footnotetext{
${ }^{69}$ Cf. Cap. 3 e Cap. 4, Seção 4.2.2, p. 113 ss.
} 
recíproca entre sintaxe de misturas e morfologia aspectual-temporal que está por trás do ofício prático de compositores e arranjadores. Não é supérfluo relembrar que esses mecanismos semióticos permanecem sempre em um âmbito de certo modo "pré-consciente" da intuição criativa, assim como os falantes de língua natural mobilizam sua competência linguística sem forçosamente ter consciência explícita disso.

Assim como ocorre nas línguas naturais, há também na linguagem orquestral e instrumental construções julgadas mais conformes às normas do que outras. Cabe então ao sujeito, em um exercício de quantificação subjetiva (Tatit, 2011), estimar a dosagem mais bem equilibrada entre timbres "cortantes" e/ou "macios" para obter os efeitos estéticos pretendidos. Tais cifras de arredondamento ou suavidade não são dados universais determinados a priori; ao contrário, estão inscritas no quadro de valores estéticos vigentes em cada contexto socio-histórico e cultural.

A segunda interface articula a dinâmica de triagens e misturas com o efeito de individuação e iconização de entidades únicas. Nela, observou-se que timbres ultraespecíficos (i.e. figurativamente densos) manifestam certa tendência à triagem. ${ }^{70}$ Reatando esse raciocínio com as operações da sintaxe extensiva que vêm trabalhadas aqui, pode-se inferir a seguinte correlação: quanto mais particular e idiossincrático for um dado timbre, maior sua tendência à triagem. Raciocinando na direção oposta, infere-se então que timbres indistintos tenderão a se imiscuir nos acompanhamentos harmônicos, conforme pontuado anteriormente a respeito da mescla e da fusão. ${ }^{71}$

Disso conclui-se que timbres genéricos (i.e. figurativamente rarefeitos) se comportam como variantes e podem ser livremente substituídos, ao passo que timbres específicos tendem a se comportar como invariantes e efetuar comutação, na acepção glossemática destes termos (cf. Hjelmslev 2006 [1943], p. 76). Assumindo a densidade figurativa como um acento de intensidade, essa constatação reverbera um princípio semiótico - infelizmente pouco lembrado nas pesquisas da área - segundo o qual o específico seleciona o inespecífico (Greimas \& Courtés, 1986 , p. 210-211, verbete "spécification"), exatamente da mesma maneira como o acentuado rege o inacentuado (Zilberberg, 2011b, p. 109-110).

Tomando como pano de fundo a problemática da seleção e combinação timbrística, a pesquisa levantou evidências que permitem relativizar, ao menos em parte, a premissa corrente de que o timbre é uma variável livremente substituível em textos verbais orais, musicais e cancionais. Os casos observados ao longo do trabalho atestaram, sob certas circunstâncias, a ação de restrições relacionadas ora à morfologia temporal interna do objeto sonoro, ora às combinatórias intertimbrísticas, ora à (in)compatibilização com seu substrato linguístico-musical. Apesar do amplo espectro de variabilidade, as possibilidades

\footnotetext{
${ }^{70}$ Cf. Seção 4.3.4, p. 136.

${ }^{71}$ Cf. Seção 4.2.2, p. 110 ss. e Seção 4.2.4, p. 126.
} 
de seleção (relações paradigmáticas) e combinação (relações sintagmáticas) de timbres não são infinitas. A despeito de sua posição de proeminência, a livre substituição do timbre é apenas o cenário mais prototípico dentre outros possíveis.

Essa conclusão só pode ser obtida por um olhar transversal que ousa colocar lado a lado textos musicais de reputado prestígio cultural e textos verbais orais frequentemente desconsiderados como objeto digno de estudos, tais como a dublagem, a locução audiovisual e grampos telefônicos. Atravessando esses dois extremos, a canção também testemunha casos emblemáticos de restrições de seleção timbrística, tanto nos domínios de maior elaboração estética quanto em seu filão puramente comercial. Essa postura resgata o princípio segundo o qual o linguista não deve fazer julgamento de valor de seu objeto de estudo. De seu lado, também o semioticista deve pôr em suspenso suas apreciações valorativas para saber extrair o denominador comum da fala, da canção e da música no que diz respeito à significação do timbre.

Com relação às contribuições trazidas pelo presente trabalho, é preciso desde já dissipar qualquer ilusão de ineditismo ex nihilo. Se há aí algum grau de originalidade, ele se deve menos à elaboração de novas ferramentas conceituais do que ao aprofundamento de hipóteses de trabalho já circulantes nas pesquisas da área, conforme recenseadas pela revisão de literatura. Mais do que apenas uma reverência protocolar aos antecessores, essa constatação impacta de maneira muito concreta no itinerário de pesquisa traçado aqui.

No capítulo 2, a categorização de timbres em uma escala de especificidade e de densidade figurativa aprofunda a concepção de timbre como figura do mundo conforme preconizada em Dietrich (2008). Por sua vez, o capítulo 3 desenvolveu os pormenores de uma descrição temporalizante do timbre em seu aspecto morfológico, conforme já aventado em Coelho (2007). Na sequência, o capítulo 4 aprofunda e operacionaliza a noção de "intervalo de timbres" apontada em Dietrich (2008) como possibilidade a verificar. Por fim, o capítulo 5 desdobra a noção de timbre como marca enunciativa da categoria de pessoa, conforme pontuado em Carmo Jr. (2007, p. 175 ss.).

Como se vê, as frentes de investigação circunscritas em cada capítulo não foram escolhas ao acaso. Ao contrário, elas derivam de propostas de investigação sugeridas por trabalhos anteriores da área em contexto nacional. Consolidando os avanços conquistados por certa geração de pesquisadores, a presente tese coloca em franco diálogo contribuições que, de outro modo, correriam o risco de continuar subaproveitando seu potencial de colaboração mútua. 


\subsection{Limites do trabalho e desiderata}

Os avanços eventualmente conquistados de um lado não se fazem, no entanto, sem esbarrar em suas limitações de outro lado. À medida que busca dar fechamento a certas questões, a presente pesquisa acaba invariavelmente abrindo outras problemáticas, que deverão ser verificadas por trabalhos futuros. Como convém a toda investigação científica honesta consigo própria, é preciso nesse momento pontuar os limites da abordagem aqui aventada, bem como o potencial de desdobramentos posteriores aí implicado.

Um dos pontos vulneráveis da investigação diz respeito aos textos empíricos submetidos à análise, especialmente aqueles empregados no exame de timbres altamente específicos. ${ }^{72}$ Devido à sua inevitável ancoragem sócio-histórica e cultural, os exemplos apresentados tendem a perder força persuasiva quanto mais afastado o leitor se encontra de um certo epicentro de tempo e espaço. A obsolescência e a alteridade sociocultural podem tornar os objetos empíricos irreconhecíveis ao público-leitor, ainda que isso jamais chegue a invalidar de fato a coerência interna da argumentação desenvolvida aqui. Assim sendo, pesquisas futuras deverão ampliar o escopo de textos analisados de modo a abranger outros contextos socioculturais e históricos.

Além de testar a robustez das ferramentas analíticas, essa expansão poderá proporcionar também maior capacidade de difusão e diálogo na comunidade científica. Para além da diversificação da representatividade do corpus, esse movimento de ampliação deverá também alargar, em termos quantitativos, as análises efetuadas aqui em pequena escala. Esse objetivo poderá ser atingido com a aplicação dos mecanismos de triagem e misturas timbrísticas ${ }^{73}$ na descrição dos mais variados estilos musicais, procurando contemplar tanto quanto possível um amplo espectro de manifestações culturais locais.

Indo na mesma direção, as considerações sobre a (in)compatibilidade entre substrato linguístico-melódico e revestimento timbrístico ${ }^{74}$ podem ser testadas com a descrição semiótica exaustiva da "linguagem" de cada instrumento musical em particular. Em outros termos, trata-se de recensear, sistematizar e semiotizar quais combinatórias rítmicomelódicas e harmônicas são consideradas implicativas e/ou concessivas em um certo timbre escolhido como parâmetro de análise.

No âmbito da canção propriamente dita, semelhante movimento de expansão pode ser vislumbrado na descrição da assim chamada "dicção do cancionista" (cf. Tatit, 2002). Ampliando o conjunto de dados empíricos analisados, essa via de trabalho consiste em verificar quais são as recorrências estáveis nas configurações de letra (isotopias temáticas, figurativas, percursos passionais e narrativos etc.) e melodia (padrões rítmico-melódicos)

\footnotetext{
${ }^{72}$ Cf. Cap. 5.

${ }^{73}$ Cf. Cap. 4.

${ }^{74}$ Cf. Cap. 5.
} 
no timbre vocal de um dado intérprete. No domínio da palavra falada, investigações posteriores poderão estreitar sua colaboração com a fonética forense, especialmente no que diz respeito à questão do anonimato, da identificação e na descrição semiótica da imagem do sujeito por trás da voz.

Quanto à descrição do perfil temporal-aspectual do timbre ${ }^{75}$, pesquisas futuras deverão buscar uma colaboração mais estreita com os trabalhos do campo da acústica e da psicoacústica. Nesse quesito, uma possível contribuição da semiótica seria esclarecer como se dá a conversão dos formantes acústicos em formas dotadas de sentido. Empregando a terminologia técnica da disciplina, trata-se aqui da problemática da passagem da forma científica à forma semiótica. Esse tópico em particular oferece um dos pontos mais férteis de colaboração interdisciplinar. A partir desse mesmo ponto, seria desejável também uma integração mais aprofundada com o Traité des objets musicaux (Schaeffer, 1966), buscando depreender dele suas invariantes semióticas formais.

Outra via de aprofundamento consiste na sistematização daquilo que vem sendo referido aqui, em termos intencionalmente genéricos, como contexto sociocultural e histórico. Os valores estéticos vigentes em uma dada cultura e em um dado momento histórico podem ser formalizados por meio dos conceitos semióticos de práxis enunciativa e de semiosfera. Delimitado pela tensão entre o conforto do conhecido e a explosão do estranho, esse espaço de circulação discursiva arbitra o que é considerado habitual e implicativo e o que é considerado desviante e concessivo. Uma tal descrição poderá contribuir para entender melhor o processo de tipificação dos timbres, quais deles são centrais e/ou periféricos em um dado recorte sócio-histórico e como se dá o trânsito entre essas instâncias.

\section{7 Últimas palavras}

As limitações e sugestões de aprimoramento apontadas não devem ser tomadas aqui como confissão de fracasso nem mesmo como fingida autodepreciação. Ao invés disso, seria preferível enxergar aí um manancial fértil de temas de investigação a ser continuamente explorado a longo prazo. Como é o destino inescapável do labor científico, o trabalho fecha algumas questões ao mesmo tempo em que abre tantas outras.

De um lado, logramos avançar um passo pequeno porém importante para entender melhor como o timbre produz significação - uma lacuna aliás grande demais para ser declarada como preenchida tão cedo. A despeito das dimensões modestas de sua contribuição, a pesquisa teve êxito em reivindicar para a semiótica seu merecido lugar nos estudos sobre timbre. Os resultados de análise corroboram a importância e a produtividade de desvencilhar a significação do timbre de suas condicionantes materiais mais imediatas.

\footnotetext{
${ }^{75}$ Cf. Cap. 3.
} 
Pela primeira vez, foi possível demonstrar como uma escala de graus de especificidade explica e descreve efeitos de sentido produzidos pelo timbre que pareciam, em um primeiro momento, não-relacionados entre si. Fazendo valer a vocação dedutiva da semiótica greimasiana, a pesquisa contribuiu para o desenvolvimento de um modelo descritivo geral transponível a diferentes contextos (socioculturais, estéticos, históricos etc.) particulares.

De outro lado, é preciso admitir de boa fé e consciência tranquila que mais dados são necessários para testar a robustez analítica das ferramentas aqui desenvolvidas. Apesar de todos os esforços em respeitar a coerência teórica interna, somente a aplicação prática nos mais diversos objetos empíricos poderá atestar o real interesse dessas reflexões. Tal exercício de análise haverá de impor ao modelo novos questionamentos e exigir dele novas soluções criativas. Esse atrito entre teoria e prática se coloca como feliz prenúncio de que sempre há, após todo fim, um recomeço. 


\section{Referências Bibliográficas}

300: A ASCEnsão De UM IMPÉRIo, 2007. Direção: Zack Snyder. Produção: Warner Bros. 1 DVD (117min).

A nova onda do Imperador, 2000. Produção: Walt Disney. 1 DVD (78 min).

AB'Saber, Tales. "A voz de Lula.", 2012. Revista Serrote, Março de 2012, Instituto Moreira Sales.

Aleh Ferreira. "Choros, Sonhos e Emoções.", 2010. Allegreto / Movieplay Digital. 1 CD (49min).

Almada, Carlos. Arranjo. 4a reimpressão. Campinas: Editora da Unicamp, 2014 [2000].

BADIR, Sémir. Épistémologie sémiotique: La théorie du langage de Louis Hjelmslev. Paris: Honoré Champion Éditeur, 2014.

BAND - UOL. "Fábio Porchat vira voz de aplicativo de GPS.", 2016a. Disponível em: <https://entretenimento.band.uol.com.br/famosos/noticias / id=100000808993>. Acesso em 09/11/2019.

. "Morgan Freeman dubla voz de aplicativo de GPS.", 2016b. Disponível em: <https: //entretenimento.band.uol.com.br/famosos/noticias/?id=100000795346\&t=>. Acesso em 09/11/2019.

Barros, Diana Luz Pessoa de. Teoria do discurso: fundamentos semióticos. São Paulo: Humanitas, 2002.

—. "Publicidade e figurativização." Alfa, vol. 2(48), 2004.

—. Teoria semiótica do texto. São Paulo: Ática, 2007.

—. Intolerância e discurso. São Paulo: Cortez, 2014a.

—. "Estudos do discurso". In: Fiorin, José Luiz (Org.). Introdução à linguística II: princípios de análise. São Paulo: Contexto, $2014 b$.

Barthes, Roland. "L'effet de réel." Communication, vol. 1(11), 1968.

—. Le grain de la voix: entretiens (1962-1980). Paris: Édition du Seuil, 1981.

Bastide, Françoise. "Figurativité et representation." Actes Sémiotiques - Bulletin, vol. 26(VI), 1983. 
1987.

Belkin, Alain. "Artistic orchestration.", 2001. Montréal: publicação eletrônica. Disponível em: <https://alanbelkinmusic.com/site/en/index.php/orchestration/>. Acesso em: $25 / 09 / 2019$.

Benevides, Aline de Lima. O acento primário em pseudopalavras: uma abordagem experimental. Dissertação de Mestrado, Faculdade de Filosofia, Letras e Ciências Humanas da Universidade de São Paulo, 2017.

Benveniste, Émile. Problemas de linguística geral I. $5^{\mathrm{a}}$ ed. Campinas: Pontes, 2005 [1966].

Problemas de linguística geral II. 2a ed. Campinas: Pontes, 2006 [1974].

Bertrand, Denis. "Du figuratif à l'abstrait." Actes sémiotiques - Documents, vol. IV(39), 1982.

. L'espace et le sens: 'Germinal' de Zola. Paris: Hadès-Benjamin, 1985. (Actes sémiotiques).

- "L'impersonnel de l'énonciation. Praxis énonciative : conversion, convocation, usage." Protée Révue internationale de théories et pratiques sémiotiques, vol. 21(1), 1993.

- Caminhos da semiótica literária. Bauru: EDUSC, 2003.

Bonnet, François J. Les mots et les sons: un archipel sonore. Paris: Éditions de l'éclat, 2012.

Bordron, Jean-François. "Percepção e iconicidade, diagrama e mônada." Estudos Semióticos [on-line] Editores convidados: Waldir Beividas e Eliane Soares de Lima São Paulo, março de 2018 Disponível em: <wwwrevistasuspbr/esse> Acesso em 'dia/mês/ano', vol. 14, n. 1 (edição especial), p. 74-82, 2018.

Buarque, Chico, Bardotti, Sèrgio \& Orquestra Petrobrás Sinfônica do Rio DE JAneiro. "Os saltimbancos sinfônico.", 2016. Rio de Janeiro: DeckDisc. 1 CD.

Calcanhoto, Adriana. "Fico assim sem você.", 2004. In: Adriana Partimpim. BMG, Ariola Records.

Cambraia, César Nardelli. "Da lexicologia social a uma lexicologia sócio-história: caminhos possíveis." Revista Estudos Linguísticos, vol. 21(1), p. 157-188, 2013.

Cançado, Márcia. Manual de Semântica. Noções básicas e exercícios. Belo Horizonte: Editora da UFMG, $2^{\text {a }}$ ed., 2008.

Capovilla, Fernando César, Varanda, Cristina \& Capovilla, Alessandra Gotuzo Seabra. "Teste de competência de leitura de palavras e pseudopalavras: normatização e validação." PSIC - Revista de Psicologia da Vetor Editora, vol. 7, n. 2, jul/dez, p. 47-69, 2006. 
CARmo JR., José Roberto do. Da voz aos instrumentos musicais: um estudo semiótico. São Paulo: Annablume/Fapesp, 2005.

Melodia e prosódia. Um modelo para a interface música-fala com base no estudo comparado do aparelho fonador e dos instrumentos musicais reais e virtuais. Tese de Doutorado, Faculdade de Filosofia, Letras e Ciências Humanas da Universidade de São Paulo, 2007.

Carros 3, 2017. Direção: Brian Fee. Produção: Pixar Animation Studios, Walt Disney Pictures, Estados Unidos: 1 DVD (102 min).

CARse, Adam. The history of orchestration. New York: Dover Publications, 1964 [1925].

Carta Capital. "Por 6 votos a 1, TSE decide barrar candidatura de Lula.", 2018. Disponível em: < https://www.cartacapital.com.br/politica/tse-forma-maioria-para-b arrar-candidatura-de-lula/>. Acesso em: 04/09/2019.

Cazes, Henrique. Choro: do quintal ao municipal. São Paulo: Editora 34, 1998.

Chico Buarque e os trapalhões. "Meu caro barão.", 1981. In: Saltimbancos trapalhões. Universal Music Ltda. 1 CD.

Coelho, Márcio Luiz Gusmão. "Alotimbre: processos de covariação no arranjo da canção popular brasileira." Estudos Linguísticos, vol. 33, p. 400-405, 2004.

- O arranjo como elemento orgânico ligado à canção popular brasileira: uma proposta de análise semiótica. Tese de Doutorado, Faculdade de Filosofia, Letras e Ciências Humanas da Universidade de São Paulo, 2007.

Courtés, Joseph. "Alguma coisa que se assemelha a uma ordem". In: Greimas, Algirdas Julien \& Landowski, Eric (Orgs.). Análise do discurso em ciências sociais. São Paulo: Global, 1986 [1979].

1991.

Crystal, David. Dicionário de linguística e fonética. 2. ed. Rio de Janeiro: Jorge Zahar, 1988.

CÂmara Municipal de Extrema. "Fique atento: não caia no golpe do falso sequestro.", s/d. Câmara Municipal de Extrema (MG). Disponível em: <http://www.camaraextr ema.mg.gov.br/noticias/fique-atento-nao-caia-no-golpe-do-falso-sequestro/>. Acesso em 09/09/2019.

Dahlhaus, Carl \& Eggebrecht, Hans Heinrich. Brockhaus Riemann Musiklexikon. 3. ed., vol. 2., Oldenburg : Atlantis Musikbuch-Verlag, 2001.

Dessons, Gérard. Émile Benveniste. Paris: Bertrand-Lacoste, 1993.

Deutsche Welle. "Lula lidera intenções de voto.", 2018. Disponível em: < https://ww w.dw.com/pt-br/lula-lidera-inten\%C3\%A7\%C3\%B5es-de-voto/a-45150959>. Acesso em: 04/09/2019. 
Dietrich, Peter. Semiótica do discurso musical: uma discussão a partir das canções de Chico Buarque. Tese de Doutorado, Faculdade de Filosofia, Letras e Ciências Humanas da Universidade de São Paulo, 2008.

Discini, Norma. O estilo nos textos. São Paulo: Contexto, 2004.

Druce, Duncan. "Top 10 viola works.", 2015. Gramophone. The world's best classical music reviews. Disponível em: <https://www.gramophone.co.uk/feature/top-10-viola -works $>$. Acesso em 06/12/2018.

Dubois, Jean et al. Dicionário de linguística. 9. ed. São Paulo: Cultrix, 2011 [1973].

DuCARD, Dominique. La voix et le miroir: une étude sémiologique de l'imaginaire et de la formation de la parole. Paris: L'Harmattan, 2002.

ECKERT, Hartwig \& LAVER, John. Menschen und ihre Stimmen: Aspekten der vokalen Kommunikation. Weihnheim: Beltz, 1994.

Eco, Umberto. Os limites da interpretação. São Paulo: Perspectiva, 2008.

EIDsheIm, Nina Sun. Voice as a Technology of Selfhood: Towards an Analysis of Racialized Timbre and Vocal Performance. Tese de Doutorado, University of California, San Diego, 2008.

Enrolados, 2011. Produção: Walt Disney Animation Studios, 1 DVD (100 min).

Estay-Stange, Verónica. "La musicalité : une configuration transversale du sensible". In: Bertrand, Denis \& Coquet, Jean-Claude (Orgs.). Sémiotique, Comment dire le sensible? Littérature, n. 163, Paris, Larousse, 2011.

. Sens et musicalité. Paris: Classiques Garnier, 2014b.

Estay-Stange, Verónica \& Bertrand, Denis. "Reflexões sobre a perspectiva gerativa em semiótica". In: Cortina, Arnaldo \& Silva, Fernando Moreno da (Orgs.). Semiótica e comunicação: estudos sobre textos sincréticos. Araraquara: Cultura Acadêmica, 2014a.

FALES, Cornelia. "The paradox of timbre." Ethnomusicology, vol. 46(1), 2002.

FARIAS, Iara Rosa. Das figuras do mundo às figuras do discurso : uma visão semiótica da percepção. Tese de Doutorado, Faculdade de Filosofia, Letras e Ciências Humanas da Universidade de São Paulo, 2002.

FARLEX Inc. "The free dictionary.", s/d. Disponível em: <https://www.thefreedictionar y.com/>. Acesso em 27/10/2019.

Favaretto, Celso. Tropicália, alegoria, alegria. 4. ed., Cotia: Ateliê Editorial, 2007 [1979].

Fiorin, José Luiz. Elementos de análise do discurso. São Paulo: Contexto, 1989.

- As astúcias da enunciação. As categorias de pessoa, espaço e tempo. São Paulo: Ática, 1999. 
. Em busca do sentido. São Paulo: Contexto, 2008 a.

—. "Linguagem e interdisciplinaridade." ALEA, vol. 10(1), p. 29-53, 2008b. Disponível em: <http://www.scielo.br/pdf/alea/v10n1/v10n1a03.pdf>. Acesso em 17/10/2018.

. "Semiótica tensiva". In: Fiorin, José Luiz (Org.). Novos caminhos da linguística. São Paulo: Contexto, 2015.

- Argumentação. São Paulo: Contexto, 2016.

. "Itinerário intelectual de Greimas: o percurso da estrutura." Estudos semióticos, vol. 13(2), p. 157-188, $2017 a$.

—. "Two concepts of enunciation." Semiotica, vol. 219, 257-271, $2017 b$.

Flaux, Nelly. "L'antonomase du nom propre ou la mémoire du réfèrent." Langue française, (92), 26-45, 1991. Disponível em: <https://www.persee.fr/docAsPDF/lfr_0023-836 8_1991_num_92_1_6210.pdf $>$. Acesso em: 17/09/2019.

FLOCH, Jean-Marie. "Quelques positions sur une sémiotique visuelle." Actes Sémiotiques Bulletin, vol. 4-5, p. 1-16, 1978.

—. Petites mythologies de l'œil et de l'esprit. Pour une sémiotique plastique. ParisAmsterdam: Hadès-Benjamins, 1985.

—. "Imagens, signos, figuras: abordagem semiótica da imagem." Cruzeiro Semiótico, vol. 15, p. 75-81, 1985b. Disponível em <http://felsemiotica.com/descargas/cruzeiros emiotico3.pdf>. Acesso em: 27/08/2019.

1995 .

Folha de SÃo PAulo. "Gravação de declaração de Maluf ao jornal Folha de São Paulo.", $2000 a$. Folha On-line, 30/08/2000, documentado por Wayback Machine. Disponível em: <https://web.archive.org/web/20001209203900/http://www.uol.com.br/folha/c otidiano/images/2000/_08/_30/_maluf.rm>. Acesso em: 04/09/2019.

- "Maluf faz insinuações sobre vida pessoal de Marta Suplicy.", 2000b. Folha On-line, 30/08/2000. Disponível em: <https://www1.folha.uol.com.br/folha/brasil/ult 96u5446.shtml>, acesso em: 09/04/2019.

Fontanier, Pierre. Les figures du discours. Paris: Flammarion, 1968.

Fontanille, Jacques. "Modes du sensible et syntaxe figurative." Nouveaux Actes Sémiotiques (NAS), vol. 61-63, p. 1-68, 1999.

—. "La patine et la conivence." Revue Protée, vol. 29(1), 2001.

—. Semiótica do discurso. São Paulo: Contexto, 2007.

Fontanille, Jacques \& Zilberberg, Claude. Tensão e significação. São Paulo: Discurso Editorial/Humanitas, 2001. 
Frozen, 2013. Direção: Chris Buck, Jennifer Lee. Produção: Walt Disney Animation Studios. Estados Unidos: 1 DVD (102 min).

G1 - GLOBo. "Golpe do falso sequestro aplicado por telefone ganha nova versão.", 2015. Disponível em: <http://g1.globo.com/jornal-nacional/noticia/2015/07/golpe-do-falso -sequestro-aplicado-por-telefone-ganha-nova-versao.html>. Acesso em 09/09/2019.

G1 - TV AnhanguerA. "Vítima do golpe do 'falso sequestro' grava ligação e simula depósito.", 2014. Disponível em: <http://g1.globo.com/goias/noticia/2014/04/v itima-do-golpe-do-falso-sequestro-grava-ligacao-e-simula-deposito.html $>$. Acesso em 09/09/2019.

Globo. "Globo: novo filme institucional sintetiza valores da marca.", 2019. Disponível em: <https://www.youtube.com/watch?v=yD0dHeA36W8>. Acesso em 06/08/2019.

GnAtalli, Radamés. "Uma história que conta como os violinos chegaram aos arranjos do samba.", 1979. Jornal da Tarde, 19 de Março.

Goethe, Johann Wolfgang Von. Doutrina das cores. 4. ed. São Paulo: Editora Nova Alexandria, 2013 [1810].

Goldhan, Wolfgang. Kennzeichen der Sängerstimme. Baltmannsweiler: Schneider, 1995.

Gomes, Ana Quadros \& Mendes, Luciana Sanchez. Para conhecer semântica. São Paulo: Contexto, 2018.

Greimas, Algirdas Julien. "A enunciação: uma postura epistemológica." Significação Revista Brasileira de Semiótica, vol. 1, Centro de Estudos Semióticos A. J. Greimas: Ribeirão Preto, p. 09-25, 1974.

- Ensaios de semiótica poética. São Paulo: Cultrix/Editora da Universidade de São Paulo, 1975 .

—. Sobre o sentido: ensaios semióticos. Petrópolis: Vozes, 1975 b.

—. Semântica estrutural: pesquisa de método. São Paulo: Cultrix, 1976 [1966].

—. Semiótica e ciências sociais. São Paulo: Cultrix, 1981.

—. "De la figurativité." Actes Sémiotiques - Bulletin, vol. 26(VI), $1983 a$.

—. Du sens II: essais sémiotiques. Paris: Seuil, $1983 b$.

—_ "Sémiotique figurative et sémiotique plastique." Actes sémiotiques - documents Paris: Institut National de la Langue Française, vol. VI, 60, 1984.

- La Mode en 1830. Essais de description du vocabulaire vestimentaire d'après les journaux de mode de l'époque. Paris: PUF, 2000 [1948].

. Da imperfeição. São Paulo: Hacker Editores, 2002.

—. Sobre o sentido II: ensaios semióticos. São Paulo: Nankin/EDUSP, 2014 [1983]. 
Greimas, Algirdas Julien, Chabrol, Claude \& Barthes, Roland. Semiótica narrativa e textual. São Paulo: Cultrix, 1977.

Greimas, Algirdas Julien \& Courtés, Joseph. Sémiotique: dictionnaire raisonne de la theorie du langage. vol. 2. Paris: Hachette, 1986.

. Dicionário de semiótica I. São Paulo: Contexto, 2012 [1979].

Greimas, Algirdas Julien \& Fontanille, Jacques. Semiótica das paixões. São Paulo: Ática, 1993.

Grey, John M. An exploration of musical timbre. Tese de Doutorado, Department of music, Stanford University, 1975.

- "Timbre discrimination in musical patterns." The Journal of the Acoustical Society of America, vol. 64(2), 467-472, 1978.

Groupe $\mu$. Rhétorique générale. Paris: Larousse, 1970.

—. Rhétorique de la poésie. Lecture linéaire, lecture tabulaire. Bruxelles/Paris: Complexe/PUF, 1977.

—. Traité du signe visuel. Pour une rhétorique de l'image. Paris: Le Seuil, 1992.

- Principia Semiotica: aux sources du sens. Bruxelles: Les impressions nouvelles, 2015.

Grover-Friedlander, Michael. "The call of the human voice in Poulenc's 'La voix humaine'". In: Austern, Linda Phyllis (Org.). Music, sensation and sensuality. Vol. 5. Routledge: New York and London, [s/d].

Harnoncourt, Nikolaus. Le discours musical. Pour une nouvelle conception de la musique. Paris: Gallimard, 1982.

Harper Collins Publishers. "Collins English Dictionary - Complete and Unabridged.", s/d. Disponível em: <https://www.collinsdictionary.com/dictionary/english>. Acesso em $27 / 10 / 2019$.

Heidemann, Kate. "A system for describing vocal timbre in popular song." MTO - A journal of the Society for Music Theory, vol. 22(1), p. 467-472, 2016. Disponível em: <http://www.mtosmt.org/issues/mto.16.22.1/mto.16.22.1.heidemann.php>. Acesso em $19 / 09 / 2017$.

Helmholtz, Hermann Von. Die Lehre von den Tonempfindungen als physiologische Gründe für die Theorie der Musik. Frankfurt am Main: Minerva Verlag, 1981 [1863].

HJelmslev, Louis. Le Langage: une introduction. Les Éditions de Minuit, 1969. 1975. . Résumé of a theory of language. Copenhague: Nordisk Sprog- og Kulturforlag, . Ensaios linguísticos. São Paulo: Perspectiva, 1991. 
Homem-Aranha, 2002. Produção: Sony Pictures. 1 DVD (121 min).

HowArd, David \& Angus, Jamie. "Hearing timbre and deceiving the ear". In: HowARD, David \& Angus, Jamie (Orgs.). Acoustics and psychoacoustics. Oxford: Focal, 2006.

Huron, David. Toward a theory of timbre. Tese de Doutorado, Cincinnati. Ohio State University, 2001. Disponível em: <http://www.musiccog.ohio-state.edu/Huron/Talks /SMTmidwest.2001/index.html>. Acesso em 19/01/2018.

HÉBERT, Louis. Dictionnaire de sémiotique générale. Quebec, 14 edição, 2018 [2007]. Disponível em: <http://www.signosemio.com/documents/dictionnaire-semiotique-gen erale.pdf $>$. Acesso em 05/11/2018.

HÉnAult, Anne. "A. J. Greimas, um projeto teórico em construção." Estudos semióticos [on-line], vol. 13(2 - edição especial), p. 6-12, 2017. Editores convidados: Waldir Beividas e Eliane Soares de Lima. São Paulo. Disponível em: <http://www.revistas.u sp.br/esse/article/view/141600/136609>. Acesso em 17/10/2018.

JAKOBSOn, Roman. "Les embrayeurs, les catégories verbales et le verbe russe". In: Jakobson, Roman (Org.). Essais de linguistique générale. Paris: Minuit, 1963.

JARDIM, Gil. "O arranjo como estrutura e tecido do discurso musical." Revista USP, vol. $111,45-58,2016$.

JonASSON, Kerstin. "Les noms propres métaphoriques : construction et interprétation." Langue française, (92), 64-81, 1991. Disponível em: <https://www.persee.fr/doc/lfr_0 023-8368_1991_num_92_1_6212>. Acesso em 17/11/2019.

Jornal Folha de SÃo Paulo. "Padre Marcelo não divulgou áudio com apoio a Jair Bolsonaro.", 2018a. Disponível em: <https://www1.folha.uol.com.br/poder/2018/0 9/padre-marcelo-nao-divulgou-audio-com-apoio-a-jair-bolsonaro.shtml $>$. Acesso em: 09/08/2019.

"Áudio pró-Bolsonaro é de apóstolo da igreja Bola de Neve, e não do padre Fábio de Melo.", 2018b. Disponível em: <https://www1.folha.uol.com.br/poder/2018/10/au dio-pro-bolsonaro-e-de-apostolo-da-igreja-bola-de-neve-e-nao-do-padre-fabio-de-mel o.shtml>. Acesso em: 09/08/2019.

Jus BRASIL. "Globo consegue reduzir indenização por pegadinha no Domingão do Faustão.", 2012. Disponível em: <https://stj.jusbrasil.com.br/noticias/3061254/glob o-consegue-reduzir-indenizacao-por-pegadinha-no-domingao-do-faustao $>$. Acesso em $20 / 08 / 2019$.

JWAVE. "Fãs se unem contra a troca de dubladores de Capitão América no Brasil.", 2016. Disponível em <http://www.jwave.com.br/2016/02/fas-se-unem-contra-a-troca-de-d ubladores-de-capitao-america-no-brasil.html>. Acesso em 04/09/2019. 
Kassler, Jamie C. "Musicology and the problem of the sonic abuse". In: Austern, Linda Phyllis (Org.). Music, sensation and sensuality. Routledge: New York and London, vol. 5, [s/d].

Keane, Teresa. "Figurativité et perception." Nouveaux Actes Sémiotiques, vol. 17, 1991.

Kennan, Kent. The technique of orchestration. Englewood Cliffs: Prentice-Hall, 1983.

Kennedy, Michael. The Concise Oxford Dictionary of Music. Oxford: Oxford University Press, 1996.

Kiefer, Bruno. Elementos da linguagem musical. 5ª ed., Porto Alegre: Movimento, 1987.

Koechlin, Charles. Traité de l'orchestration. vol. 1, Paris: Max Esching, s/d.

Krumhansl, Carol L. "Why is musical timbre so hard to understand?" Structure and perception of electroacoustic sound and music, vol. 9, 43-53, 1989.

KöNIG, Ekkerhard \& BRAndT, Johannes. "Die Stimme-Charakterisierung aus linguistischer Perspektive". In: Kolesch, Doris \& Krämer, Sybille (Orgs.). Stimme. Annäherung an ein Phänomen. Frankfurt: Suhrkamp, 2006.

LA CASA DE PAPEL, 2017. Espanha. Produção: Vancouver Media e Atresmedia. Distribuição: Antena 3 e Netflix. 2 temporadas, 23 episódios.

Lindenberg Lemos, Carolina. Condições semióticas da repetição. Tese de Doutorado, Faculdade de Filosofia, Letras e Ciências Humanas da Universidade de São Paulo / Faculté de Philosophie et Lettres da Université de Liège, 2015.

. "A linearidade entre estrutura e manifestação". In: Altman, Cristina \& TestaToreli, Lygia (Orgs.). Por ocasião do centenário do Curso de Linguística Geral (1916). São Paulo: FFLCH/USP, 2017. Disponível em <https://www.teses.usp.br/teses/dispo niveis/8/8139/tde-09062015-111352/pt-br.php>. Acesso em 11/12/2017.

LOPEs, Edward. A identidade e a diferença: raízes históricas das teorias estruturais da narrativa. São Paulo: Editora da Universidade de São Paulo, 1997.

Lopes, Ivã Carlos. "Extensidade, intensidade e valorações em alguns poemas de Antônio Cícero". In: Lopes, Ivã Carlos \& Hernandes, Nilton (Orgs.). Semiótica: Objetos e práticas. São Paulo: Contexto, 2005.

Lyotard, Jean-François. La phénoménologie. Paris: PUF, 1954.

LÉOn, Pierre. Précis de phonostylistique. Nathan: Paris, 1993.

Machado, Regina. Da intenção ao gesto interpretativo: análise semiótica do canto popular brasileiro. Tese de Doutorado, Faculdade de Filosofia, Letras e Ciências Humanas, Universidade de São Paulo, 2012.

Macho, Thomas. "Stimmen ohne Körper: Anmerkung zur Techikgeschichte der Stimme". In: Kolesch, Doris \& KrÄmer, Sybille (Orgs.). Stimme. Annäherung an ein Phänomen. Frankfurt: Suhrkamp, 2006. 
Mancini, Renata. "Um balanço do projeto temático em torno de traduções intersemióticas.", 2014.

Mancini, Renata Ciampone. Dinamização no percurso gerativo de sentido: canção e literatura contemporânea. Tese de Doutorado, Faculdade de Filosofia, Letras e Ciências Humanas, Universidade de São Paulo, 2005.

- "Sem greimas, com greimas, após greimas, cem greimas." Estudos Semióticos Edição especial de homenagem ao centenário de A J Greimas - parte II, vol. 14, 22-27, 2018. Disponível em: <http://www.revistas.usp.br/esse/article/view/144306>. Acesso em 30/04/2020.

. "A enunciação tensiva em diálogo." Estudos Semióticos, vol. 15, edição especial, 64-87, 2019a. Disponível em: <http://www.revistas.usp.br/esse/article/view/156074/1 $52320>$. Acesso em 09/10/2019.

. "Os modos de engajamento do leitor de grande sertão: veredas em quadrinhos." Revista todas as letras (MACKENZIE Online), vol. 21, edição especial, 100-113, 2019b. Disponível em: <http://editorarevistas.mackenzie.br/index.php/tl/article/view/123 40>. Acesso em 30/04/2020.

Menezes, Flo. A acústica musical em palavras e sons. Cotia: Ateliê Editorial, 2 ed., 2003.

Merleau-Ponty, Maurice. Fenomenologia da percepção. São Paulo: Martins Fontes, 1999.

Merriam-Webster. "Merriam-webster on-line dictionary.", s/d. Disponível em: < https: //www.merriam-webster.com/>. Acesso em 03/02/2018.

Metallica e Orquestra Sinfônica de SÃo Francisco. "Metallica: S\&M.”, 1999. Berkeley: Elektra-Vertigo. 2 CD (150min).

Mintz, Daniel. "Toward timbral synthesis. a new method for synthesizing sound based on timbre description schemes.", 2007.

Miranda, Carmem. "Eu dei.", 2013 [1937]. In: Carmem Miranda 1937. Entertain Me Europe LTD. Original: Regional Odeon.

Monte, Heraldo do. "Heraldo do Monte.", 2016. Biscoito Fino. 1 CD (34 min).

NAttiez, Jean-Jacques. Music and Discourse: Toward a Semiology of Music. Princeton, NJ: Princeton University Press, 1990.

Paulo: Via Lettera, 2005.

NeEdLe, Janet; Hay Jennifer, Jeremy; Pierrehumbert. "Phonotactic and morphological effects in the acceptability of pseudowords.", 2017. Workshop on Morphological Typology and Linguistic Cognition. Disponível em: <http://www.phon.ox.ac.uk/jpierrehumbert /publications/pseudowords_mtlc_share.pdf>. Acesso em: 29/01/2019. 
Negócios - Globo. "Atlas de cobertura.", 2015. Disponível em: <https: //web.archive.org/web/20150110135113/http://comercial2.redeglobo.com.br/atlasdec obertura/Paginas/Totalizador.aspx>. Acesso em 09/09/2019.

News, Blasting. "Irritados com troca de dubladores em 'Game of Thrones', fãs pedem pra 'ressuscitar' vozes.", 2016. Disponível em: <https: //br.blastingnews.com/tv-famosos/2016/05/irritados-com-troca-de-dubladores-e m-game-of-thrones-fas-pedem-pra-ressuscitar-vozes>. Acesso em: 08/07/2019.

NoAIlly, Michèle. "« Etre Chauteaubriand ou rien »." Langue française, (146), 39-52, 2005. Disponível em: <https://www.persee.fr/docAsPDF/lfr_0023-8368_2005_num 146_2_6616.pdf $>$. Acesso em 17/10/2019.

O Estado de São Paulo. "A voz na tela.", 2018. Caderno 2, Página C1 e C3, 1 de Julho de 2019.

de Setembro de 2019.

Oxford Dictionary. "Oxford dictionary on-line, verbete 'frenemy'.", s/d. Disponível em: <https://en.oxforddictionaries.com/definition/frenemy>. Acesso em 03/02/2019.

PARret, Herman. Le sublime du quotidien. Paris/Amsterdam: Éditions Hádes-Benjamin, 1988.

- La voix et son temps. Bruxelles: De Boeck Supérieur, 2002.

—. "Vin et voix: vers une inter-esthésique des qualités sensorielles." Visible, vol. 1, Limoges: Pulim, p. 117-130, 2005.

—_Épiphanies de la présence: essais sémio-esthétiques. Limoges: PULIM, 2006.

—. "Bruit, son, ton, voix." Actes Sémiotiques [En ligne], (113), 2010. Disponível em: $<$ http://epublications.unilim.fr/revues/as/2835>. Acessado em 19/10/2015.

Partido dos Trabalhadores. “'É o Brasil feliz de novo' - Jingle de campanha 2018.", 2018.

Pascalis, Olivier et al. "Development of face processing." Wiley interdisciplinary reviews Cognitive science, vol. 2(6), 666-675, 2011. Disponível em: <https://www.ncbi.nlm.nih .gov/pmc/articles/PMC3203018/>. Acesso em 26/08/2019.

Passetti, Renata Regina \& Barbosa, Plínio Almeida. "Análise fonético-acústica de disfarces vocais com aplicações para a fonética forense." Cadernos de Estudos Lingüisticos, vol. 60(3), 567-583, 2018. Disponivel em: <https://periodicos.sbu.unica mp.br/ojs/index.php/cel/article/view/8651760>. Acesso em 05/11/2019.

Pereira, Flávia Vieira. As práticas de reelaboração musical. Tese de Doutorado, Escola de Comunicação e Artes da Universidade de São Paulo, 2011. 
Persépolis, 2008. França, Estados Unidos. Direção: Vincent Paronnaud e Marjane Satrapi. Produção: 2.4.7 Films. 1 DVD (96 min).

Pietroforte, Antonio Vicente Seraphim. Tópicos de semiótica : modelos teóricos e aplicações. São Paulo: Annablume, 2008.

Pietroforte, Antônio Vicente Seraphim \& Lopes, Ivã Carlos. "Semântica lexical". In: Fiorin, José Luiz (Org.). Introdução à linguística II: princípios de análise. São Paulo: Contexto, 2004.

Piovezani, Carlos. "Usos e sentidos da voz no discurso político eleitoral brasileiro." Alfa, vol. 55(1), p. 163-176, 2011. Disponível em: <https://periodicos.fclar.unesp.br/alfa/a rticle/view/4172>. Acesso em 04/09/2019.

"Discursos da mídia brasileira sobre a voz de Lula." Filologia e linguística portuguesa, vol. 16(2), p. 311-329, 2014. Disponível em: <http://www.revistas.usp.br/ flp/article/view/80830>. Acesso em 04/09/2019.

. "A voz de Lula na imprensa brasileira: discursos da mídia sobre a fala pública do ex-presidente." Conexão Letras, vol. 12(18), p. 11-26, 2017. Disponível em: <https: //seer.ufrgs.br/conexaoletras/article/view/79492>. Acesso em 04/09/2019.

Piston, Walter. Orchestration. New York: W. W. Norton \& Company Inc. Publishers, 1955.

Polguère, Alain. Lexicologia e semântica lexical. Noções fundamentais. São Paulo: Contexto, 2018.

Portal Brasil. "Portal institucional desenvolvido pelo governo federal brasileiro.", 2011. Disponível em: <http://www.brasil.gov.br/cidadania-e-justica/2011/05/ator-w agner-moura-grava-chamadas-de-radio-para-campanha-do-desarmamento $>$. Acesso em $10 / 11 / 2018$.

PoyAtos, Fernando. "Paralinguistic qualifiers: our many voices." Language and Communication, vol. 11(3), p. 181-195, 1991. Disponível em: <https://e-edu.nbu.bg/pluginfile.php/376370/mod_resource/content/1/Poyato s\%20-\%20Paralinguistic\%20qualifiers\%20-\%20our\%20many\%20voices.pdf $>$. Acesso em: $25 / 01 / 2018$.

Prado, Maria Goreti Silva \& Santos, Flávia Karla Ribeiro. "Epistemologia e história dos conceitos de enunciação e figuratividade na semiótica francesa." Entretextos, vol. 17(2), p. 275-302, 2017.

Prope, Vladimir. Morfologia do conto maravilhoso. Rio de Janeiro: Forense-Universitária, 1984.

Pugialli, Ricardo. No embalo da Jovem Guarda. Rio de Janeiro: Ampersand, 1999.

Quinteiro, Eudosia Acuña. Estética da voz. Uma voz para o ator. São Paulo: Summus, 1989. 
RAZAFIndRAKoto, Jobonina. "Le timbre dans le répertoire de la valiha, cithare tubulaire de Madagascar." Cahiers d'ethnomusicologie, vol. 12, p. 123-142, 1999. Disponivel em: $<$ http://ethnomusicologie.revues.org/847>. Acesso em: 19/01/2018.

Reboul, Olivier. Introdução à retórica. São Paulo: Martins Fontes, 1998.

Rede Globo. "Entrevista com Pelé - O rei do futebol relembra momentos marcantes e emocionantes da carreira.", 2018. Disponível em: <https://www.youtube.com/watch?v $=$ XWpJgrWHls8 $>$. Acesso em: 08/07/2019.

ReED, Smith Alexander. The musical semiotics of timbre in the human voice and Static takes love's body. Tese de Doutorado, University of Pittsburgh, 2005.

Ribeiro, Solano. Prepare seu coração. A história dos grandes festivais. São Paulo: Geração Editorial, 2002.

Rimsky-Korsakov, Nikolay. Principles of orchestration: with musical examples drawn from his own works. vol. I, Paris: Édition Russe de Musique. Editado por Maximilian Steinberg, tradução de Edward Agate, 1922a [1873-1874].

- Principles of orchestration: with musical examples drawn from his own works. vol. II, Paris: Édition Russe de Musique. Editado por Maximilian Steinberg, tradução de Edward Agate, 1922b [1873-1874].

Russolo, Luigi. L'art des bruits: manifeste futuriste 1913. Paris: Allia, 2003 [1913].

SAD Levi, Jorge. "Timbre y significación: Por una semiología de las formas sonorosimbólicas.", 2018. Disponível em: <http://www.sulponticello.com/timbre-y-significac ion-por-una-semiologia-de-las-formas-sonoro-simbolicas/\#.W0cCCsJ9iHs $>$. Acesso em $20 / 08 / 2019$.

Saraiva, José Américo Bezerra \& Leite, Ricardo Lopes. Exercícios de Semiótica Discursiva. Fortaleza: Imprensa Universitária, 2017.

Saussure, Ferdinand de. Curso de linguística geral. 16. ed. São Paulo: Cultrix, 1991 [1916].

—. Escritos de linguística geral. São Paulo: Cultrix, 2004.

Schaeffer, Pierre. Traité des objets musicaux. Paris: Éditions du Seuil, 1966.

. Traité des objets musicaux: essais interdisciplines. Paris: Éditions du Seuil, 2002.

SChafer, Murray. O ouvido pensante. 2. ed., São Paulo: Ed. Unesp, 2011.

Schilling, Natalie \& Marsters, Alexandria. "Unmasking identity: Speaker profiling for forensic linguistic purposes." Annual Review of Applied Linguistics, vol. 35, 195-214, 2015.

Scorpions. "Moment of glory.", 2001. Alemanha. Produção: Zweites Deutsches Fernseher (ZDF). 1 DVD (108 min). 
Seashore, Carl. Psychology of music. New York: Dover publications, 1967.

Segreto, Marcelo. A canção e a oralização: sílaba, palavra e frase. Tese de Doutorado, Faculdade de Filosofia, Letras e Ciências Humanas da Universidade de São Paulo, 2019. Disponível em: <https://www.teses.usp.br/teses/disponiveis/8/8139/tde-26062019-103 725/pt-br.php>. Acesso em 11/12/2016.

Severiano, Jairo. Uma história da música popular brasileira. Das origens à modernidade. $2^{\mathrm{a}}$ ed., São Paulo: Ed. 34, 2009.

Sheehan, Michael J. \& Nachman, Michael W. "Morphological and population genomic evidence that human faces have evolved to signal individual identity." Nature Communications, (5), 2014. Disponível em: <https://www.nature.com/articles/ncomms5800>. Acesso em 26/08/2019.

ShimodA, Lucas Takeo. "Semiotic description of timbre and usage-related variants: An exploratory analysis of orchestration handbooks." Signata, vol. 6, p. 43-64, 2015. Disponível em: <https://journals.openedition.org/signata/pdf/1060>. Acesso em 17/10/2018.

Shrek, 2001. Direção: Andrew Adamson, Vicky Jenson. Produção: Dreamworks Animation. 1 DVD (90 min).

Siblot, Paul \& Leroy, Sarah. "L'antonomase entre nom propre et catégorisation nominale." Mots, (63), 89-104, 2000. Disponível em: <https://www.persee.fr/docAsP DF/mots_0243-6450_2000_num_63_1_2207.pdf>. Acesso em: 17/11/2019.

Silva, Ignácio Assis. Figurativização e metamorfose: o mito de Narciso. São Paulo: Editora da UNESP, 1995.

Silva, Thaïs Chistófaro. Dicionário de fonética e fonologia. 1. ed. São Paulo: Contexto, 2017.

Stalnaker, Robert. Context and content: Essays on Intentionality in Speech and Thought. Oxford University Press, 1999.

Stegner-Petitjean, Isabelle. "The Voice in the Mirror'. Michael Jackson : d'une identité vocale à sa mise en image sonore." Volume ! [En ligne], vol. 2(8), p. 43-64, 2011. Disponível em: <http://journals.openedition.org/volume/2760>. Acesso em: $12 / 02 / 2019$.

SundBerg, Johan. "Singing and timbre." Music room acoustics, vol. 17, 57-81, 1977.

—. "Perceptual aspects of singing." Journal of voice, vol. 8(2), 106-122, 1994.

—. "The perception of singing." The psychology of music, p. 171-214, 1999.

. In: "The human voice in speech and singing". Springer handbook of acoustics. New York: Springer, 2007.

Sundberg, Johan \& Rossing, Thomas D. "Voice timbre in solo and choir singing: Is there a difference?" The Journal of the Acoustical Society of America, vol. 76, 1984. 
. "The science of singing voice." The Journal of the Acoustical Society of America, vol. $87(1), 462-463,1990$.

SundBerg, Johan \& ThalÉn, Margareta. "Describing different styles of singing: A comparison of a female singer's voice source in 'classical', 'pop', 'jazz' and 'blues'." Logopedics Phonatrics Vocology, vol. 26(2), 82-93, 2001.

TAtit, Luiz. A canção: eficácia e encanto. São Paulo: Atual, 1986.

—. Musicando a semiótica. São Paulo: Annablume/FAPESP, 1997.

—. Análise semiótica através das letras. São Paulo: Ateliê editorial, 2001.

- O cancionista: composição de canções no Brasil. São Paulo: EDUSP, 2002.

—. "A abordagem do texto". In: Fiorin, José Luiz (Org.). Introdução à linguística II: princípios de análise. São Paulo: Contexto, 2004a.

—. O século da canção. São Paulo: Ateliê Editorial, $2004 b$.

- Todos entoam: ensaios, conversas e canções. São Paulo: Publifolha, 2007.

—. "A extinção que nunca se acaba - 'nenhum, nenhuma.". Alfa, vol. 53(2), 405-427, 2009 .

—. "A canção e as oscilações tensivas." Estudos semióticos, vol. 6(2), p. 14-21, 2010. Disponível em: <http://www.revistas.usp.br/esse/article/view/49266/53348>. Acesso em $04 / 01 / 2016$.

—. "Quantificações subjetivas: crônicas e críticas." Cadernos de Letras da UFF Dossiê: Linguagens em diálogo, vol. 42, p. 35-50, 2011.

- Todos entoam: ensaios, conversas e cançôes. $2^{\mathrm{a}}$ ed., revista e ampliada, Cotia: Ateliê Editorial, 2014.

- Estimar canções: estimativas íntimas na formação do sentido. Cotia: Ateliê Editorial, 2016.

Thürlemann, Felix. "'Le rouge et le noir' di Paul Klee”. In: Corrain, Lucia (OrG.) (Org.). Semiotiche della pinttura. I classici. Le richerche. Roma: Meltemi editore, 2004.

Transversal Frevo Orquestra. "Frevo encantado.", 2010. Disponível on-line em: <https://www.youtube.com/watch?v=z-FcddEQUMM>. Acesso em 22/01/2019.

TRIngali, Dante. Introdução à retórica: a retórica como crítica literária. São Paulo: Duas Cidades, 1988.

Tropa De Elite, 2007. Brasil. Direção: José Padilha. Produção: Zazen Produções. 1 DVD (115 min.).

TuCKER, Patrick. Secrets of screen acting. New York/London: Routledge, 2015. 
UOL. "As 15 melhores dublagens feitas por famosos.", 2016. Disponível em: <https://legi aodosherois.uol.com.br/lista/15-melhores-dublagens-feitas-por-famosos.html>. Acesso em 04/09/2019.

"30 animações que foram dubladas por celebridades brasileiras.", 2018. Disponível em: <https://www.bol.uol.com.br/listas/celebridades-brasileiras-que-emprestaram-s ua-voz-para-personagens.htm>. Acesso em 04/09/2019.

UOL Confere. "Haddad e Manuela não tramaram contra Exército em 'áudio vazado'.", 2018. Disponível em: <https://noticias.uol.com.br/comprova/ultimas-noticias/20 18/10/16/haddad-e-manuela-nao-tramaram-contra-exercito-em-audio-vazado.htm $>$. Acesso em: 09/11/2019.

UOL MAIs. "Veja íntegra da sabatina UOL, Folha e SBT com Fernando Haddad (PT).", 2018. Disponível em: <https://mais.uol.com.br/view/1575mnadmj5c/veja-integra-da-s abatina-uol-folha-e-sbt-com-fernando-haddad-pt-0402CD1B3268D0A96326>. Acesso em: 09/11/2019.

Veloso, Caetano \& Buarque, Chico. "Caetano e Chico juntos e ao vivo.", 1972. Universal Music Ltda.

Veloso, Caetano, Buarque, Chico \& Gil, Gilberto. "O que é que a baiana tem?", 2014. In: DorIval Caymmi - Centenário. Biscoito fino. 1 CD (61 min.).

Veloso, Caetano \& GiL, Gilberto. "Dois amigos, um século de música (ao vivo).", 2015. Uns Produções Artísticas ltda. e Gege Produções Artísticas ltda. Sob licença de Sony Music Entertainment Brasil; 1 CD (99 min).

WAldiRene. "Garota do roberto.", 1967. In: WAldiREne. São Paulo: BMG Records. 1 CD (38 min).

WiSNIK, J.M. O som e o sentido: uma outra história das músicas. São Paulo, Companhia das Letras, 1989.

XAVIER, Ismail. "Viagem pela heterodoxia." Significação, vol. 14, 2000.

—. "O narrador no cinema.", 2017. Disponível em: < https://www.youtube.com/wa tch?v=bHBZ4RQQMZk>. Acessado em: 20 de Agosto de 2019.

Yo-Yo MA. "Obrigado brazil.", 2003. Sony BMG Music Entertainment, 1 CD (72 min).

Zilberberg, Claude. "Aspectualisation et dynamique discursives". In: Fontanille, Jacques (Org.). Le discours aspectualisé. Limoges / Amsterdam / Philadelphia: PULIM / Benjamins, 1991.

. "Présence de Wölfflin.” Nouveaux Actes Sémiotiques, (23-24), 1992.

—. "Seuils, limites, valeurs". In: HÉNAult, Anne (Org.). Questions de sémiotique: sous la direction de A. Hénault. Paris, 2002. 
"As condições semióticas da mestiçagem". In: CAÑIzAL, Eduardo Peñuela \& Caetano, Kati Eliana (Orgs.). O olhar à deriva: mídia, significação e cultura. São Paulo: Annablume, 2004.

Razão e poética do sentido. São Paulo: Editora da Universidade de São Paulo, $2006 a$.

. "Síntese da gramática tensiva." Significação - Revista Brasileira de Semiótica, vol. 25. São Paulo, Annablume, p. 163-204, 2006 b.

. "Louvando o acontecimento." Revista Galáxia, vol. 13. São Paulo, p. 13-28, 2007.

—_ "Causerie sur la sémiotique tensive.", 2008. Disponível em: <http://www.fflch.us p.br/dl/semiotica/cursos/zilberberg2008/cz-causerie.pdf>. Acessado em: 15 de Julho de 2012 .

—. Des formes de vie aux valeurs. Paris: PUF, 2011 .

—. Elementos de semiótica tensiva. São Paulo: Ateliê Editorial, $2011 b$.

- La structure tensive: suivi de Note sur la structure des paradigmes et de la dualité de la poétique. Presses Universitaires de Liège, 2012.

Zinna, Alessandro. "Les objet et ses interfaces". In: Zinna, Alessandro \& Fontanille, Jacques (Orgs.). Les objets du quotidien. Limoges: Pulim, 2005. 